\title{
JUVENTUDE, VIOLÊNCIA E AÇÃO COLETIVA
}

\author{
FÁTIMA MADALENA DE CAMPOS LICO
}

Tese apresentada ao Programa de Pós-Graduação em Saúde Pública para obtenção do título de Doutor em Saúde Pública.

Área de Concentração: Serviços de Saúde Pública

Orientadora: Profa. Dra. Márcia Faria Westphal 
Aos meus amores: Delcio, Flávio, Mayara e Fabiana 


\section{AGRADECIMENTOS}

Às Subprefeituras da Capela do Socorro e M' Boi Mirim, pelo apoio e pela colaboração no desenvolvimento dessa pesquisa;

às Supervisões Técnicas de Saúde Socorro e M' Boi Mirim, pelo apoio e pela facilitação do processo de coleta de dados junto às Unidades de Saúde das regiões;

à Coordenadoria de Ensino da Região Metropolitana da Grande São Paulo, pela autorização para realização da pesquisa juntos às escolas estaduais das regiões de estudo;

às Delegacias de Ensino das regiões da Capela do Socorro e Campo Limpo, pela autorização para realização da pesquisa nas escolas das regiões dos distritos de estudo;

às Coordenadorias de Educação de Socorro e Campo Limpo, pela autorização e colaboração no processo de coleta de dados;

ao Instituto Sou da Paz, em especial Cláudia e Thiago, pelo apoio e pelas importantes contribuições;

ao Padre Jaime, pelo apoio a este estudo e pelas valiosas contribuições;

aos jovens e pais entrevistados que aceitaram partilhar suas vivências e experiências e cujas vozes irradiaram sentidos ao estudo.

às Entidades e ONGs que atuam nos distritos e que participaram do estudo, pelo apoio e pela valiosa colaboração;

aos profissionais das escolas municipais e estaduais dos distritos que participaram deste estudo, pelas valiosas contribuições;

aos profissionais de saúde das Unidades dos distritos do Grajaú e Jardim Ângela, pelas importantes contribuições, tempo e energia depositados;

à querida Márcia Faria Westphal, pela distinta orientação, dedicação, amizade e confiança depositada;

aos professores, membros da Banca Examinadora, por suas valiosas contribuições, alguns desde a qualificação deste projeto;

às professoras Cleide Lavieri Martins, Cláudia Bógus e Rosilda Mendes, pelo apoio, incentivo e pelas importantes contribuições; 
a Pedro Vieira, pelas importantes contribuições e pela eficiente consultoria estatística;

à Fernanda, pelo carinho, amizade e eficiente coordenação de campo dessa pesquisa; aos pesquisadores Tarcis, Grace, Raime, pela valiosa colaboração na digitação dos dados desta pesquisa;

a todos os pesquisadores que participaram do processo de coleta de dados, pela competência e dedicação;

a Delcio, companheiro querido pelo carinho, pela colaboração e imensa paciência pela minha pouca disponibilidade durante a realização deste trabalho;

aos meus filhos, Flávio, Mayara e Fabiana pelo carinho, apoio, pela compreensão e pela importante colaboração nas diferentes fases deste trabalho;

aos amigos do Cepedoc e do Departamento de Prática de Saúde Pública, pelo apoio, carinho e valiosa colaboração;

ao Conselho Nacional de Desenvolvimento Científico e Tecnológico (CNPq), pelo financiamento do estudo;

a todos os amigos que acompanharam e contribuíram nesta trajetória. 
LICO, F. M. C. Juventude, Violência e Ação Coletiva [Tese de Doutorado]. São Paulo: Faculdade de Saúde Pública da Universidade de São Paulo, 2009.

\section{RESUMO}

Introdução: $O$ presente estudo tem como objeto de análise as ações coletivas para enfrentamento da violência e as construções sociais dos jovens, pais, lideranças e profissionais de saúde, educadores e gestores sobre o que é ser jovem e violência nos distritos administrativos do Jardim Ângela e Grajaú no município de São Paulo. Objetivos: analisar e comparar os processos que orientam as ações coletivas e as experiências participativas de promoção da saúde dos jovens realizadas pelas organizações governamentais e não-governamentais para o enfrentamento e resistência à violência, nos Distritos Administrativos do Grajaú e Jardim Ângela, visando contribuir para a construção de uma cultura de paz e implementação de políticas públicas para a juventude local. Metodologia: estudo de caso qualitativo, que compreendeu a articulação de dados obtidos por meio de entrevistas individuais, formulários semi-estruturados, questionários auto-aplicáveis e levantamentos de dados secundários. Para a análise, a estratégia metodológica principal utilizada foi a triangulação das informações. O referencial teórico fundado na sociologia da ação foi o marco a partir do qual as informações foram analisadas. Resultados: verificou-se uma tendência de queda maior da taxa de mortalidade por agressões/homicídios no distrito do Jardim Ângela do que no de Grajaú, a partir de 2002. Apesar da redução registrada nos índices de violência, estes são, ainda, elevados nos dois distritos em relação ao restante do município. $\mathrm{Na}$ análise da rede de proteção aos jovens, constatou-se que as intervenções estão voltadas principalmente para a redução do risco de violência, com foco na educação, cultura, desenvolvimento socioeducativo, que muitas vezes incluem programas educacionais e culturais, prática de esportes e lazer, principalmente. Evidenciou-se que os jovens não atuam como protagonistas nas políticas públicas e nas ações coletivas nos distritos e ainda que aqueles que não freqüentam mais a escola estão excluídos das políticas públicas e dos projetos das entidades. Quanto à visão de juventude, predomina a da fase de dificuldades e de transição para a vida adulta. Para os jovens é uma fase de diversão e de preparo para 
assumirem as responsabilidades futuras. Seus projetos de vida são: estudar e trabalhar. A família, a escola e o trabalho foram considerados importantes instituições de socialização. Os jovens gostam das regiões onde vivem e não as consideram violentas, contrastando com as percepções sobre a violência dos atores que não residem nos distritos. Foram identificados como principais problemas das regiões a falta de infra-estrutura, de saneamento básico, falta de espaço de convivência, de áreas e equipamentos de lazer e cultura para os jovens. A violência doméstica é um grave problema nas regiões, assim como o consumo de álcool e drogas e a atuação do tráfico. Conclusão: Constatou-se que, no distrito do Jardim Ângela, ocorreu uma maior mobilização da sociedade civil com desenvolvimento de ações coletivas para enfrentamento da violência e, recentemente, no Distrito do Grajaú, vêm ocorrendo ações e articulações entre o poder público e a sociedade civil para o enfrentamento do problema. Em ambos os distritos, os jovens pesquisados não atuam como protagonistas das ações. Aqueles que deixaram de estudar não têm acesso às ações das entidades e tentam realizar seu projeto de vida de outra forma: as meninas engravidam e constituem família; os meninos buscam a rua, o trabalho informal e não-qualificado. As políticas públicas e ações coletivas destinadas à juventude são fragmentadas e desarticuladas em ambos distritos. A rede de proteção aos jovens é difusa, as escolas têm papel preponderante e as entidades têm vocação para a prática assistencial. No DA do Jardim Ângela, o quadro apresenta-se de uma forma pouco diferenciada, cabendo um papel relevante a uma rede de entidades lideradas pela Igreja Católica e a uma ação mais integrada das Unidades de Saúde.

Descritores: Juventude; violência; promoção da saúde; subjetividade; rede e cultura de paz. 
LICO, F. M. C. Youth, violence and collective action [Thesis]. São Paulo (BR): Faculdade de Saúde Pública da Universidade de São Paulo, 2009.

\begin{abstract}
Introduction: The object of analysis of the present study are the collective actions developed to face violence and the social constructions of youths, parents, leaders and health professionals, educators and managers about what it is to be young and about violence in the administrative districts of Jardim Ângela and Grajaú, in the municipality of São Paulo. Objectives: to analyze and compare the processes that guide the collective actions and the participatory experiences of health promotion for youths carried out by governmental and non-governmental organizations, in order to face and resist violence, in the Administrative Districts of Grajaú and Jardim Ângela, aiming to contribute to the construction of a culture of peace and implementation of public policies targeted at the local youths. Methodology: qualitative case study that comprehended the articulation of data obtained through individual interviews, semi-structured forms, self-reported questionnaires and surveys of secondary data. For the analysis, the main methodological strategy used was triangulation of information. The theoretical framework founded on action sociology was the benchmark based on which the information was analyzed. Results: the mortality rate by aggressions/homicides showed a higher decreasing trend in the district of Jardim Ângela compared to Grajaú, from 2003 onwards. Despite the reduction registered in the violence indicators, they are still high in the two districts compared to the rest of the municipality. In the analysis of the youths protection network, it was verified that the interventions' main objective is to reduce the risk of violence, focusing on education, culture, and socioeducational development. The interventions frequently encompass educational and cultural programs, sports practice and leisure. It was observed that the youths do not act as players in the public policies and in the collective actions in the districts, and also that those who do not attend school anymore are excluded from the public policies and from the entities' projects. Concerning the view of youth, the ones that predominate are: youth as a phase of difficulties and of transition to adult life; to the youths, it is a phase of entertainment and preparation for assuming future responsibilities. Their life projects are: studying and working. Family, school and work were considered important socialization institutions. The youths like the regions where they live, and they do not consider them violent, in opposition to the violence perceptions of the players that do not live in the districts. The main problems identified in the regions were lack of infrastructure, of basic sanitation, of premises for conviviality, leisure,
\end{abstract}


cultural activities and equipment for the youths. Domestic violence is a serious problem in the regions, as well as alcohol and drug consumption and the traffic's actions. Conclusion: in the District of Jardim Ângela, there was a greater mobilization of the civil society, with the development of collective actions to face violence, whereas in the District of Grajaú, there have been recent actions and articulations between the public power and the civil society to face the problem. In both districts, the researched youths are not the players of the actions. Those who do not study anymore do not have access to the entities' actions and try to fulfill their life projects in another way: girls get pregnant and form a family and boys go to the streets, looking for informal and non-qualified jobs. The public policies and collective actions directed at youths are fragmented and disorganized in both districts. The youths protection network is diffuse, schools have a preponderant role and the entities have a vocation for assistentialism. In Jardim Ângela, the picture is a little different, due to the relevant role played by a network of entities leaded by the Catholic Church, and by the more integrated action of the Health Care Units.

Descriptors: Youth; violence; health promotion; subjectivity; network and peace culture. 


\section{SUMÁRIO}

APRESENTAÇÃOO 20

1.INTRODUÇÃO 24

1.1. O CONTEXTO SOCIAL DA JUVENTUDE 24

1.1.1 A juventude e o cenário mundial 24

1.1.2. A juventude e o cenário brasileiro 28

1.1.3. A juventude e a violência no Brasil 32

2. OBJETIVOS 39

2.1. OBJETIVOS GERAIS 39

2.2. OBJETIVOS ESPECÍFICOS 39

3. OS JOVENS NO CONTEXTO DAS POLÍTICAS PÚBLICAS 41

3.1. A CONCEPÇÃO DE JUVENTUDE 41

3.2. PARA COMPREENDER OS JOVENS 44

3.3. O JOVEM E O MARCO JURÍDICO INTERNACIONAL 46

3.4. O JOVEM E O MARCO JURÍDICO NACIONAL 49

4. CONCEITUANDO A VIOLÊNCIA 53

4.1. AS TIPOLOGIAS DA VIOLÊNCIA 57

4.2. AS DIMENSÕES DA VIOLÊNCIA 60

4.3. FATORES E CONDIÇÕES QUE EXPLICAM A VIOLÊNCIA RELACIONADA À JUVENTUDE NO BRASIL 63

4.4. VIOLÊNCIA, JUVENTUDE E POLÍTICAS PÚBLICAS 66

5. A NOÇÃO DE TERRITÓRIO 70

6. PARTICIPAÇÃO SOCIAL

7. A EXPERIÊNCIA SOCIAL E A AÇÃO 75

7.1. AS LÓGICAS DE AÇÃO 81

7.2. COMPREENDENDO AS LÓGICAS DE AÇÃO 82

7.3. A EXPERIÊNCIA SOCIAL E O SISTEMA 88

8. SUJEITO SOCIAL 93 
9. A CONCEPÇÃO DE PROMOÇÃO DA SAÚDE PARA O ENTENDIMENTO DA RELAÇÃO JUVENTUDE E VIOLÊNCIA 98

10. O REFERENCIAL TEÓRICO CONSTRUÍDO PARA ANÁLISE 102 11.METODOLOGIA 104

11.1. A CONCEPÇÃO DA PESQUISA 104

11.2.O DESENVOLVIMENTO DO ESTUDO DE CASO 106

11.2.1.Fase Exploratória - Seleção das áreas de estudo 106

11.2.2. Entrevistas com informantes chaves das instituições que atendem $\begin{array}{ll}\text { adolescentes para construção gradual da amostra } & 107\end{array}$

11.3. PROCEDIMENTOS PARA A COLETA DE DADOS 107

11.3.1. Técnicas de Coleta de Dados 108

11.3.2. Composição da Amostra 108

11.4. ASPECTOS ÉTICOS DA PESQUISA 119

11.5. ANÁLISE DOS DADOS 119

12. RESULTADOS E DISCUSSÃO 126

12.1. OS JOVENS SUAS FAMÍLIAS E A COMUNIDADE 127

12.1.1 Conhecendo os jovens estudantes 127

12.1.2. Conhecendo os jovens que não freqüentam mais a escola 133

12.1.3.Conhecendo os pais dos jovens que não freqüentam a escola 138

12.2. A ANÁLISE POR TRIANGULAÇÃO DOS DADOS 141

12.3. AS PERCEPÇÕES DAS LIDERANÇAS, EDUCADORES E PROFISSIONAIS DE SAÚDE SOBRE OS JOVENS 146

13. A SUBJETIVIDADE DOS JOVENS E AS CONSTRUÇÕES SOCIAIS SOBRE A JUVENTUDE: O QUE É SER JOVEM?

13.1. ANÁLISE DOS DISCURSOS DO SUJEITO COLETIVO DOS JOVENS ESTUDANTES E NÃO ESTUDANTES 150

13.2. ANÁLISE DOS DISCURSOS DO SUJEITO COLETIVO DOS PAIS DOS $\begin{array}{lc}\text { JOVENS NÃO ESTUDANTES } & 156\end{array}$

13.3. ANÁLISE DOS DISCURSOS DO SUJEITO COLETIVO DAS

ENTIDADES E LIDERANÇAS 160

13.4 ANÁLISE DOS DISCURSOS DO SUJEITO COLETIVO DOS PROFISSIONAIS DA EDUCAÇÃO 
13.5. ANÁLISE DOS DISCURSOS DO SUJEITO COLETIVO DOS PROFISSIONAIS DA SAÚDE

14. OS TERRITÓRIOS: HISTÓRIA, CONTEXTO, INTERAÇÕES E PERCEPÇÕES DOS ATORES

14.1. ASPECTOS HISTÓRICOS DA REGIÃO DA CAPELA DO SOCORRO 175

14.2. ASPECTOS HISTÓRICOS DA REGIÃO DE M'BOI MIRIM

14.3. CARACTERIZAÇÃO DOS DISRITOS

14.4. O TERRITÓRIO SOB A ÓTICA DOS ATORES

207

14.4.1. As percepções dos jovens e dos seus pais sobre os territórios 207

14.4.2. Percepções dos educadores sobre a escola

14.4.3. O território segundo as lideranças, educadores e profissionais de saúde comparado com as opiniões do jovens e dos pais dos jovens fora da escola. 213

15. AS CONSTRUÇÕES SOCIAIS DOS JOVENS SOBRE A

VIOLÊNCIA

219

16. AS CONSTRUÇÕES SOCIAIS DOS JOVENS SOBRE A PAZ

17. AS AÇÕES COLETIVAS NOS DISTRITOS DO GRAJAÚ E JARDIM

ÂNGELA

17.1. PROJETOS, PROGRAMAS E AÇÕES DESENVOLVIDOS NOS

DISTRITOS DO GRAJAÚ E JARDIM ÂNGELA

17.2. REDES SOCIAIS DE PROTEÇÃO AOS JOVENS

17.2.1 A identificação de uma rede de proteção

17.3. AS ENTIDADES E SUAS RELAÇÕES

18. AÇÕES COLETIVAS E POLÍTICAS PÚBLICAS NO GRAJAÚ E JARDIM ÂNGELA

18.1. POLÍTICAS PÚBLICAS NA REGIÃO DO GRAJAÚ

18.2. AÇÕES COLETIVAS NO JARDIM ÂNGELA

18.3. POLÍTICAS PÚBLICAS DA SUBPREFEITURA DE M'BOI MIRIM

18.3.1.Projetos e Ações da Subprefeitura de M'Boi Mirim

19. DISCUSSÃO

20. CONCLUSÃO

21. REFERÊNCIAS BIBLIOGRÁFICAS 


\section{LISTA DE FIGURAS, QUADROS E TABELAS}

Figura 1- Elementos a serem considerados na Promoção da Saúde do Jovem 104 Figura 2 - Resultados Quantitativos do DSC dos jovens - Idéia Central - fale sobre o que é ser jovem.

Figura 3 - Resultados Quantitativos do DSC Pais dos jovens-Idéias Central -Fale sobre o que é ser jovem.

Gráfico 3 - Resultados Quantitativos do DSC das Entidades e Lideranças -Idéias Centrais - Fale sobre o que é ser jovem.

Figura 5 - Resultados Quantitativos do DSC dos profissionais da educação - Idéias

Central - Fale sobre o que é ser jovem

Gráfico 6 - Resultados Quantitativos do DSC dos profissionais de saúde - Idéia

Central - Fale sobre o que é ser jovem.

Figura 7 - Município de São Paulo e as subprefeituras

Figura 8 - Distribuição percentual dos domicílios por faixa de renda mensal em salários mínimos (1), segundo distritos e município de São Paulo (MSP) - 2000. 187 Figura 9 - Grupos de vulnerabilidade social por setor censitário, segundo os distritos de Jardim Ângela e Grajaú - 2000.

Figura 10 - Localização de favelas em distritos da região Sul do município São Paulo - 2000.

Figura 11 - Taxa de fecundidade entre mulheres segundo a faixa de idade -2007 .

Figura 12 - Evolução da taxa de mortalidade infantil (1) entre 2000 e 2007 no município de São Paulo.

Figura 13 - Evolução da taxa de mortalidade geral (1) entre 2000 e 2006 no município de São Paulo.

Figura 14 - Evolução do número de homicídios no município de São Paulo e distritos de estudo entre 1996 e 2007.

Figura 15 - Densidade de ocorrência de homicídios entre jovens de 15 a 24 anos no município de São Paulo - 2000 e 2005.

Figura 16 - Resultados Quantitativos - Idéias Centrais - O que você entende por violência? 
Figura 17 - Resultados Quantitativos- Idéia Central - O que você entende por paz?

Figura 18 - Análise de correspondência - AC entre as entidades e o tipo de programadas associações indicadas - Grajaú.

Figura 19 - Análise de correspondência AC, entre as entidades e o tipo de programa das associações indicadas - Jardim Ângela.

Figura 20 - Sociograma da rede de apoio da região do Grajaú.

Figura 21 - Sociograma da rede de apoio da região do Jardim Ângela

Quadro 1: Metodologia - Coleta de dados.

Quadro 2 - Motivos apresentados pelos jovens e pais para não freqüentar a escola, por ordem de citação.

Quadro 3 - Aspectos positivos e negativos da escola segundo os jovens.

Quadro 4 - Temas de conversas com os pais.

Quadro 5 - Como os jovens ocupam as horas de folgas no DA Grajaú e Jardim Ângela.

Quadro 6 - Grupos de jovens nas regiões por ordem de citação.

Quadro 7 - Formas de lazer existentes nas regiões segundo entrevistados para os jovens.

Quadro 8- Lugares mais procurados para lazer pelos jovens por ordem de Freqüência

Quadro 9 - Triangulação dos motivos apresentados pelos jovens estudantes e não estudantes e dos pais destes, para gostarem dos territórios.

208

Quadro 10 - Triangulação dos motivos apresentados pelos jovens estudantes e não estudantes para não gostarem dos territórios.

Quadro 11 - Triangulação das contradições relacionadas à violência, dos jovens estudantes e não estudantes nos territórios .

Quadro 12 - O que mais incomoda nos bairros por ordem de citação.

Quadro 13 - Violências existentes nos distritos por ordem de freqüência.

Quadro 14 - Propostas para as regiões por ordem de citação. 
Tabela 1. Composição da amostra segundo as fases da pesquisa - DA Grajaú e Jardim Ângela - São Paulo, 2008

Tabela 2 - Nível de ensino dos jovens que freqüentam a escola - DA Grajaú e Jardim Ângela - São Paulo, 2008.

Tabela 3 - Com quem os jovens que freqüentam a escola moram - DA Grajaú e Jardim Ângela - São Paulo, 2008

Tabela 4 - Com quem os jovens que não freqüentam a escola moram - DA Grajaú e Jardim Ângela - São Paulo, 2008.

Tabela 5 - População residente e estimada, participação percentual no total do município e taxa geométrica de crescimento anual entre 1991 e 2007, subprefeituras e distritos de estudo.

Tabela 6 - Total da população residente estimada e distribuição percentual por sexo, segundo município, subprefeitura e distritos de estudo em 2007.

Tabela 7 - Distribuição da população estimada por faixa de idade e sexo, segundo distritos e município de São Paulo em 2007.

Tabela 8 - Percentual da população por grupo de vulnerabilidade, segundo distritos e município de São Paulo, 2000.

Tabela 9 - Percentual de domicílios e de responsáveis por domicílios pelo conjunto de variáveis características da condição de precariedade dos assentamentos, segundo distritos de estudo e município de São Paulo, 2000.

Tabela 10 - Índice de matrículas por nível de ensino, segundo município e distritos de estudo, 2006.

Tabela 11 - Número de estabelecimentos e matrículas por nível de ensino, segundo distritos de estudo e município de São Paulo, 2006.

Tabela 12 - Distribuição percentual de gestantes e o número de consultas médicas de exame pré-natal, segundo distritos de estudo e município de São Paulo (MSP), 2007.

Tabela 13 - Distribuição percentual de peso ao nascer, segundo distritos de estudo e município de São Paulo, 2007.

Tabela 14 - Número de nascidos vivos, óbitos e taxa de mortalidade infantil, segundo distritos de estudo e município de São Paulo, 2007. 
Tabela 15 - Percentual de óbitos segundo as causas de morte, nos distritos de estudo e município de São Paulo, 2007.

200

Tabela 16 - Percentual de causas de morte por causas externas (Cap. XX - CID 10) junto a população de 10 a 49 anos, segundo sexo e distritos de estudo e município de São Paulo, 2007.

Tabela 17 - Número e tipo de equipamentos de atenção à saúde nos distritos de estudo e município de São Paulo, 2008.

Tabela 18 - População, número de unidades hospitalares, leitos disponíveis e leitos por mil habitantes, segundo subprefeituras de Capela do Socorro, M'Boi Mirim, distritos e município de São Paulo, 2007.

Tabela 19 - Número de equipamentos culturais por tipo, segundo o município e subprefeituras da região de estudo, 2007.

Tabela 20 - Número de equipamentos por tipo e vinculação administrativa, segundo município e distritos de estudo, 2007.

206

Tabela 21 - Existência de áreas verdes em m2 por tipo, segundo o município de São

Paulo e subprefeituras da região de estudo, 2008.

207

Tabela 22 - Tipo de Associação - DA Grajaú e Jardim Ângela, São Paulo, 2008. 228

Tabela 23 - Tipos de projetos e ações das escolas- DA do Grajaú e Jardim Ângela -

São Paulo, 2008.

Tabela 24 - Participantes dos projetos - DA Grajaú e Jardim Ângela - São Paulo, 2008.

Tabela 25 - Formas de participação dos jovens nos projetos das escolas - DA

Grajaú e Jardim Ângela - São Paulo, 2008.

Tabela 26 - Área de atuação dos projetos - DA Grajaú e Jardim Ângela São Paulo, 2008.

Tabela 27 - Forma de participação dos jovens nos projetos e ações das entidades DA- do Grajaú e Jardim Ângela - São Paulo, 2008.

Tabela 28 - Objetivos dos programas, projetos e ações desenvolvidos pelas Unidades de Saúde - DA do Grajaú e Jardim Ângela - São Paulo, 2008.

235

Tabela 29 - Tipos de entidades existentes no DA Grajaú e Jardim Ângela - São Paulo, 2008. 
Tabela 30 - Indicações de associações e entidades pelos entrevistados - Da Grajaú e Jardim Ângela- São Paulo, 2008.

Tabela 31 - Número de associações e entidades indicadas pelos entrevistados - DA Grajaú e Jardim Ângela, São Paulo, 2008.

Tabela 32 - Tipo de programas e ações, segundo entidades entrevistadas - DA

Grajaú e Jardim Ângela, São Paulo, 2008. 


\section{LISTA DE SIGLAS}

ACS - Agente Comunitário de Saúde.

Cebrap Centro Brasileiro de Análise e Planejamento

Cecco - Centro de Convivência e Cooperativa Interlagos

Cedeca-Centro de Defesa da Criança e do Adolescente.

Cejam - Centro de estudos e Pesquisa João Amorim-

CEM - Centro de Estudos da Metrópole.

Cenpec - Centro de Estudos e Pesquisas em Educação Cultura e Ação Comunitária

CEU - Centro Educacional Unificado

CID - Classificação Internacional de Doenças.

CRAF - Centro de Referência da Família.

CRSSUL - Coordenadoria Regional de Saúde Sul.

DA - Distrito Administrativo.

Desa - Departamento de Assuntos Econômicos e Sociais.

EJA - Educação de Jovens e Adultos.

Fundação Seade - Fundação Sistema Estadual de Análises de Dados.

Fundap - Fundação do Desenvolvimento Administrativo.

IBGE - Instituto Brasileiro de Geografia e Estatística.

IVJ - Índice de Vulnerabilidade Juvenil.

MS - Ministério da Saúde.

ODM - Objetivos do Millenium.

ONG - Organização não governamental.

ONU - Organização das Nações Unidas.

Oscip - Organização da Sociedade Civil de Interesse Público

Proaim - Programa de Aprimoramento sobre Informações de Mortalidade no

Município de São Paulo.

PSF - Programa Saúde da Família.

Sabesp - Companhia de Saneamento Básico do Estado de São Paulo.

Saresp - Sistema de Avaliação de Rendimento Escolar do Estado de São Paulo. 
SEE - Secretaria de Educação do Estado de São Paulo.

Sempla - Secretaria Municipal de Planejamento.

SENASP - Secretaria Nacional de Segurança Pública.

SESC - Serviço Social do Comércio.

SIM - Sistema de Informações sobre Mortalidade.

SMS - Secretaria Municipal da Saúde.

SVS - Secretaria de Vigilância em Saúde.

UMAPAZ - Universidade Livre do Meio Ambiente e Cultura de Paz 
APRESENTAÇÃO

Qualidade de vida pressupõe o reconhecimento do imperativo ético de responder às necessidades sociais, no marco dos direitos sociais fundamentais, posto que o direito à saúde evidencia-se como expressão direta do direito fundamental à vida. A Promoção da Saúde nesta perspectiva ampla dotada deve voltar-se para o desenvolvimento e reforço das potencialidades e da autonomia.

Abrasco, 2003 
Partindo da premissa de que no campo da saúde pública é possível realizar ações de Vigilância e Promoção da Saúde e ações integradas com outros setores da sociedade, advogando por políticas públicas intersetoriais que diminuam a violência e/ou reduzam o seu impacto, foi proposto o presente estudo. O objetivo é analisar e comparar os processos que orientam as ações coletivas e as experiências participativas dos jovens na relação com as organizações governamentais e nãogovernamentais. É também analisar suas construções sociais, formadas na relação com seus pais, lideranças com quem têm contato, profissionais de saúde, educadores e gestores sobre o que consideram como ser jovem, a violência e as ações coletivas engendradas para o seu enfrentamento nos Distritos Administrativos do Grajaú e do Jardim Ângela, na cidade de São Paulo.

Os locais escolhidos para o estudo foram os Distritos Administrativos do Grajaú e do Jardim Ângela, regiões periféricas e de exclusão da cidade de São Paulo, onde são mais altos os coeficientes de morbimortalidade por causas externas. Em um desses distritos, o do Jardim Ângela, existe um movimento, liderado pela Igreja, que tem sido considerado capaz de integrar as ações coletivas realizadas naquele território e assim desenvolver uma estratégia para diminuir os coeficientes de mortalidade por causas externas, bastante altos na região. A experiência desse distrito tem sido bastante difundida em conferências de saúde realizadas em outros distritos e em municípios vizinhos.

O estudo tem por finalidade conhecer as ações desenvolvidas nas regiões para enfrentamento e resistência à violência. e analisar o sentido que a juventude e a violência assumem nas representações e experiências dos jovens, com suas famílias, nas escolas que freqüentam e em relação aos programas governamentais e nãogovernamentais que lhes são oferecidos.

Considerando que os múltiplos pertencimentos dos sujeitos estruturam a identidade, tanto individual quanto coletiva, e que essa identidade se constrói a partir de experiências comuns que se confrontam, buscamos entender como os jovens estão construindo suas identidades, marcando espaços de sociabilidade e troca de experiências para reconhecimento e construção dos sentidos de pertencimento nos distritos de estudo, a partir de suas experiências no cotidiano. 
Tendo em vista que as experiências sociais têm ao mesmo tempo um caráter objetivo e intersubjetivo, no estudo qualitativo pretende-se analisar o campo das representações acessíveis diretamente dos enunciados discursivos.

As contribuições teóricas do campo da Promoção da Saúde, da sociologia da ação e da noção de experiência social foram utilizadas na formulação de um referencial teórico para a análise dos resultados. Os objetos das análises serão as representações dos jovens e dos demais atores relacionados com eles - pais e professores e as ações coletivas existentes nos territórios onde residem, estudam, trabalham e desfrutam horas de lazer.

A hipótese inicial do estudo é a de que a existência de políticas públicas e de ações coletivas integradas com a participação dos jovens no distrito administrativo do Jardim Ângela do município de São Paulo tem reduzido os coeficientes de mortalidade por homicídios na população no referido distrito. O distrito do Grajaú, com características semelhantes em termos de vulnerabilidade social ao do Jardim Ângela, não tem alcançado os mesmos resultados em relação à redução da mortalidade por homicídios na população jovem, em função da desarticulação e fragmentação das políticas públicas e das ações coletivas locais e da falta de protagonização dos jovens.

A temática escolhida deve-se à relevância e à magnitude da violência social no país e na cidade de São Paulo, sendo os jovens considerados as principais vítimas, como mostram diversos estudos que serão abordados no desenvolvimento desta pesquisa. O fato de os jovens estarem em período de crescimento e desenvolvimento e de formação da identidade, por representarem o futuro da sociedade e, ao mesmo tempo, serem muito vulneráveis, devido às dificuldades que vivem, desafia a todos, especialmente a Academia, que deve avaliar as novas formas de abordar a questão, verificando possibilidades de concretização e efetivação de programas para o enfrentamento do problema.

Cabe ao setor saúde, ao assumir a perspectiva da Promoção da Saúde, ampliar o enfoque das pesquisas sobre violência e juventude, focalizando o jovem e sua família nos territórios em que vivem, onde compartilham características relativamente similares de natureza cultural e socioeconômica, vivenciam problemas, 
ameaças e oportunidades semelhantes. Assumindo esta responsabilidade, a concepção desta pesquisa teve como referência o ideário que considera o cidadão em sua totalidade, com necessidades individuais e coletivas a serem atendidas em um território onde as instituições e entidades devem organizar suas ações para superar problemas complexos, como o da violência especialmente quando a maior vítima é o jovem. Teve base também no fato de que as relações entre os homens e destes com o ambiente são construídas socialmente, no espaço geográfico onde os indivíduos e suas famílias vivem, orientando-se pelas condições positivas e negativas proporcionadas pela infra-estrutura local disponível e as ações coletivas existentes.

Os problemas reais vivenciadas nesses territórios e as potencialidades locais, segundo referencial utilizado, têm uma causalidade múltipla, engendrada na complexidade das relações entre os indivíduos, grupos e o ambiente social/natural. Para superar problemas, como o da violência, que prejudicam o desenvolvimento dos jovens, os setores governamentais e não-governamentais, as instituições e as entidades necessitam de elementos para analisar as situações complexas que precisam enfrentar, com vistas a melhorar a efetividade de suas ações.

O presente estudo, que teve apoio do CNPq, objeto desta tese de doutorado, foi organizado em duas partes. Na primeira parte, descreve-se a concepção da pesquisa, com referencial teórico que abarcou a noção de juventude, violência, experiência social, promoção da saúde, a noção de território e participação. A segunda parte compreende os resultados da pesquisa empírica, a discussão e conclusões, partindo do referencial teórico proposto. 
INTRODUÇÃOO 


\section{INTRODUÇÃO}

A juventude na contemporaneidade tem-se constituído objeto de inúmeros estudos, em diferentes perspectivas e abordagens: psicológica, sociológica, pedagógica, antropológica. Estas analisam e procuram explicar as importantes mudanças físicas, psicológicas e comportamentais que ocorrem nessa fase de vida e a condição juvenil (ABERASTURY, KNOBEL, 1982; MINAYO, 1999, SPÓSITO, 2003; DAYRELL, 2003).

Esses autores mostram que circulam no imaginário social idéias que associam a juventude à noção de crise, de irresponsabilidade, de problema social, com carência de políticas públicas e também à noção de vulnerabilidade (SPÓSITO, 2003; DAYRELL, 2003; ABRAMO,2003; AYRES, 2009). Os jovens são vulneráveis ao abuso de álcool e drogas, à delinqüência, à gravidez precoce, aos problemas na vida escolar e às diferentes formas de violência no cotidiano (AYRES, 2009 , no prelo).

O tema juventude tem ocupado o centro das atenções por causa dos problemas gerados pelo agravamento das desigualdades sociais e também no que diz respeito à esperança de novos caminhos para a transformação social, com valores e padrões éticos diferentes dos que predominam na atualidade. Os jovens estão entre as principais vítimas do processo de acumulação econômica vigente nas últimas décadas na maior parte dos países do mundo. A origem dos problemas parece não ser individual, local, nacional nem global, mas produto das transformações por que o mundo está passando e que têm repercussões nos diferentes níveis da vida social. (INSTITUTO CIDADANIA, 2004; MINAYO, 2002; MELLO, 1999).

\subsection{O CONTEXTO SOCIAL DA JUVENTUDE}

\subsubsection{A juventude e o cenário mundial}

O World Youth Report 2005: Young People Today and in 2015, Relatório Mundial sobre a Juventude: Os Jovens Hoje e em 2015, lançado pelo Programa das Nações Unidas para a Juventude, do Departamento de Assuntos Econômicos e Sociais - Desa, (ONU, 2005) chama a atenção para a necessidade de intensificar os 
investimentos nas políticas e ações destinadas aos jovens a fim de implementar o Programa de Ação Mundial para a Juventude e realizar os "Objetivos de Desenvolvimento do Milênio". Deixa claro, também, a necessidade de os dirigentes mundiais olharem para o futuro com o objetivo de assegurar o bem-estar da próxima geração: as crianças de hoje serão os jovens de 2015, ano fixado para a consecução de muitos dos ODM (ONU,2000).

Segundo o Relatório Mundial sobre a Juventude são mais de 200 milhões de jovens vivendo na pobreza, 130 milhões de jovens analfabetos, 88 milhões de desempregados, e 10 milhões infectados por HIV/Aids.

O World Youth Report descreve a situação dos jovens do grupo etário dos 15 aos 24 anos no mundo, apesar das diferenças culturais, sociais e comunitárias, abrangendo três grandes grupos de questões:

1- Os jovens e a economia mundial, analisando questões como a fome, a pobreza, a educação, o emprego, a globalização e as tecnologias de informação e comunicação.

2- Os jovens na sociedade civil, relacionado com os problemas do meio ambiente, lazer, participação e as relações intergerações.

3- Os jovens em situação de risco, compreendendo as áreas prioritárias de saúde, vício, delinquiência, conflitos e HIV/Aids.

No que concerne à educação, segundo o relatório, o número de crianças que concluem o ensino fundamental tem aumentado desde 1995, e quatro em cada cinco jovens do grupo etário apropriado freqüentam atualmente o ensino médio. No ensino superior também houve aumento e calcula-se que, atualmente, há cerca de 100 milhões de jovens matriculados no ensino superior no âmbito mundial. Embora a atual geração de jovens seja mais instruída, há 113 milhões de crianças que não freqüentam a escola. Entretanto, apesar de os jovens receberem mais educação, o desemprego entre eles, no mundo, aumentou para índices sem precedente, afetando um total de 88 milhões de indivíduos, sendo mais elevado na Ásia Ocidental, Norte de África e África ao Sul do Saara. Conseqüentemente as pressões sobre os jovens, no sentido de competirem em um mercado de trabalho global, têm aumentado, fazendo com que muitos imigrem para outros países a fim de procurar oportunidades de trabalho. 
A análise realizada pelo World Youth Report mostra que a globalização tem produzido mudanças profundas sobre a vida dos jovens, no que se refere à distribuição das oportunidades de trabalho, imigração, cultura juvenil, consumismo, cidadania e ativismo. Embora os jovens sejam flexíveis e possuam, talvez, mais facilidade em adaptar-se às novas oportunidades oferecidas pela globalização, verifica-se que muitos, sobretudo nos países em desenvolvimento, não têm se beneficiado com essas mudanças.

Com relação à pobreza, o relatório mostra que o número de jovens vivendo com menos de 1 dólar por dia é de mais de 200 milhões, ou $18 \%$ do total de jovens, e 515 milhões vivem com menos de dois dólares por dia. Outro aspecto importante da pobreza, freqüentemente ignorado, é a a transmissão para outras gerações e a consequiência para os jovens.

No que concerne às relações intergerações, em uma sociedade em processo de envelhecimento, o relatório mostra que é essencial compreender melhor a dinâmica intergeracional para definir intervenções políticas eficazes, visando atender às crescentes necessidades de atenção às pessoas idosas para o desenvolvimento da sociedade como um todo.

O relatório recomenda que as análises das relações intergeracões devem considerar o contexto e as tendências culturais. É na etapa da transição entre a infância e a idade adulta que os jovens criam sua própria identidade, incorporando dos pais normas e valores culturais e adaptando-os à sociedade atual. A globalização dos meios de comunicação tem ampliado para além do universo familiar o repertório de normas e valores com que os jovens criam suas identidades e isto pode agravar as diferenças culturais entre as gerações. A lacuna digital entre os jovens e as gerações anteriores também intensificam essa diferença. Apesar da influência das tecnologias de informação e comunicação na estrutura de socialização dos jovens, a família continua sendo a primeira instituição social em que as gerações se encontram e interagem.

O relatório analisa também a importância que vem sendo atribuída, na última década, ao lazer, à participação e ao acesso às oportunidades que as tecnologias de informação e comunicação oferecem para os jovens. Esta tendência está associada à crescente relevância da participação da juventude nos processos de tomada de 
decisão, o que contribui para o desenvolvimento pessoal e para a consciência social, melhorando a concepção e execução das políticas de juventude. A mobilização e o apoio das organizações jovens locais, segundo o relatório, serão cruciais para alcançar os Objetivos do Milênio, visando garantir a sustentabilidade do meio ambiente.

A dependência crescente de novos tipos de tecnologias da informação e comunicação é um fator determinante na vida de muitos jovens dos nossos dias, propiciando uma diversidade cada vez maior de possibilidades para obter informação, relacionarem-se, divertirem-se e reforçarem a autonomia. A Internet tem sido uma componente importante da revolução das tecnologias de informação e comunicação para os jovens. À medida que estes têm acesso a esses meios de comunicação e seus conteúdos "globais", surge uma cultura mundial da juventude, estabelecendo novos tipos de laços. A abertura e acessibilidade das novas tecnologias aumentam, em particular, as possibilidades de os jovens partilharem suas opiniões e experiências e contribuírem para o próprio desenvolvimento cultural, o que se traduz, cada vez mais, em um fluxo de socialização bidirecional entre as gerações mais novas e as mais velhas.

Outra questão analisada pelo relatório refere-se ao HIV/Aids que se tornou a principal causa de mortalidade dos jovens, seguida da violência e das lesões. Atualmente, há 10 milhões de jovens infectados pelo HIV/Aids, a maioria na África e na Ásia. A propagação do vírus tem tido um impacto devastador na saúde sexual e reprodutiva dos jovens. Uma outra questão referente à saúde dos jovens é o consumo de drogas sintéticas, sem precedentes, no âmbito mundial, sobretudo em ambientes recreativos. A procura por substâncias ilícitas entre os jovens dos países em desenvolvimento aumentou para níveis que atualmente se equiparam aos dos países industrializados.Verificou-se, ainda, haver uma forte ligação entre a vitimização dos jovens e a criminalidade. Além disso, a pobreza, a disfunção familiar, o abuso de substâncias e a morte de parentes são fatores de risco que contribuem para a delinqüência juvenil.

O mesmo documento analisa também os conflitos violentos no mundo e o impacto dramático na vida dos jovens em uma perspectiva de gênero. Nas últimas décadas, surgiram muitos conflitos, principalmente na África ao Sul do Saara, que 
afetam um número desproporcional de jovens, quer como perpetradores, quer como vítimas da violência. A situação das crianças-soldado tem sido amplamente documentada, e foram adotados vários instrumentos jurídicos internacionais que incluem diversas medidas de prevenção para ajudar a resolver esta questão; infelizmente, esses instrumentos não protegem os jovens com mais de 18 anos de idade.

O aumento dos conflitos armados, bem como o terrorismo, tem concentrado a atenção mundial em jovens do sexo masculino e em seu potencial de violência. Em consequiência disso, as experiências e capacidades dos jovens de ambos os sexos que não participam de conflitos armados, mas são afetados por eles, não têm merecido a devida atenção, assim como as mulheres jovens que estão ativamente envolvidas na violência armada.

\subsubsection{A juventude e o cenário brasileiro}

O tema juventude ganhou visibilidade crescente no Brasil, principalmente nos últimos anos. O total de crianças, adolescentes e jovens na população brasileira atingiu cerca de 80 milhões de pessoas, o que corresponde a mais de $50 \%$ do total da população, portanto uma parcela significativa de habitantes do país (MELLO JORGE et. al, 2002). Os jovens na faixa etária de 15 a 24 anos somavam 34 milhões, representando cerca de $20 \%$ da população brasileira, aumentando o peso significativo dessa categoria etária na população. Desse total, a proporção de adolescentes entre 15 e 18 anos incompletos, conforme definição do Estatuto da Criança e Adolescente (Lei 8.069, de 13 de julho de 1990), foi de 10.727 .038 (31\%). Na faixa etária de 18 ou 19 anos $7.222 .250(21,4 \%)$ e, na faixa de 20 a 24 anos, alcançou $15.828 .372(47,6$ $\%)$, conforme censo do IBGE (2000).

Embora se verifique um grande contingente de jovens no país, conforme Pesquisa Nacional por Amostra de Domicílios - Pnad (2007), ao analisar o período de 2006 a 2007, observou-se que o contingente da população de 40 anos ou mais de idade cresceu 4,2\%, enquanto o grupo mais jovem, de 0 a 14 anos, apresentou redução de $0,7 \%$, confirmando a tendência de envelhecimento populacional do nosso país (IBGE, 2007). 
Segundo a pesquisa, esse comportamento se repete em todas as regiões, com exceção da Região Norte, onde na faixa etária de 0 a 14 anos foi registrado um crescimento de $1,3 \%$ no período. Os maiores percentuais de pessoas de 0 a 4 anos foram verificados na Região Norte, sobretudo em Roraima e Amapá, com participação de 10,9\%. Já as menores participações nessa faixa etária ficaram com os estados das regiões Sudeste e Sul como, por exemplo, Rio de Janeiro (5,7\%), São Paulo (6,3\%), Santa Catarina (6,1\%) e Rio Grande do Sul (6,3\%) (IBGE,2007).

O Brasil, que possui uma das piores distribuições de renda do mundo e profundas desigualdades socioeconômicas, amplia para as crianças, adolescentes e jovens a vulnerabilidade social. Há no país graves problemas educacionais, de moradia, de oportunidades de trabalho e de lazer e, conseqüentemente, grandes desigualdades nas formas de adoecimento e morte. Essas desigualdades expressam-se diretamente na capacidade de o jovem obter reconhecimento de seus direitos elementares, tais como educação, nutrição, moradia, boa saúde física e mental, trabalho, lazer, oportunidade para o uso do tempo livre e para participação social (MINAYO, 1999; OPS, 1990).

No que se refere às desigualdades resultantes da inserção no mercado de trabalho e das formas de ocupação no país, da população geral e dos jovens, verificase que o número de pessoas ocupadas no país aumentou. A Pesquisa Nacional por Amostra de Domicílios - 2007, mostrou que houve uma queda no desemprego de 1,8\% nos anos entre 2006 e 2007. Em 2007, havia no Brasil 159 milhões de pessoas em idade ativa (dez anos ou mais de idade), 2,0\% mais que em 2006. Dessas, 62,0\% eram economicamente ativas, ou seja, estavam inseridas no mercado de trabalho. Em 2006, a taxa de atividade havia sido estimada em $62,4 \%$, percentual semelhante a de 2007.

Conforme Pnad (2007), verificou-se também que a desigualdade nos rendimentos caiu em relação aos anos anteriores, mas ainda persiste. A análise efetuada do período entre 2004 e 2007, demonstrou que houve reduções sucessivas no índice de GINI, no país (0,547, em 2004; 0,543, em 2005; 0,540, em 2006; e 0,528 em 2007). Tais reduções, apesar de persistentes, tiveram baixo impacto. Em 2007, os $10 \%$ da população ocupada com os mais baixos rendimentos detiveram $1,1 \%$ do total dos rendimentos de trabalho, enquanto os $10 \%$ com os maiores 
rendimentos recebiam $43,2 \%$, demonstrando que a concentração de rendimento ainda persiste.

A Pesquisa evidenciou que no ano de 2007 havia 4,8 milhões de crianças e adolescentes trabalhando no Brasil, representando 10,8\% das pessoas de 5 a 17 anos neste ano, pouco menos que os $11,5 \%$ do ano anterior. No ano de 2007 , quase um terço $(30,5 \%)$ das crianças e adolescentes de 5 a 17 anos ocupados trabalhava pelo menos 40 horas semanais, e uma em cada cinco $(19,8 \%)$ morava em domicílios com rendimento per capita inferior a um quarto do salário mínimo.

No que se refere ao trabalho infantil, embora tenha se verificado uma redução no país, de acordo com a Pnad (2007), com a proporção de crianças e adolescentes entre 5 a 17 anos que trabalhavam caindo de 11,5\%, em 2006, para 10,8\%, em 2007, ou seja, de um total de 44,7 milhões de pessoas nesta faixa etária, a redução foi de 5,1 milhões para 4,8 milhões de trabalhadores (menos cerca de 300 mil ocupados). A pesquisa evidenciou a existência e a persistência do trabalho ilegal no país, isto é, os jovens continuam exercendo atividades não qualificadas e o trabalho infantil tem reflexo negativo nas taxas de frequiência à escola.

Na faixa etária de 5 a 13 anos, em que o trabalho infantil é considerado ilegal, a pesquisa revelou que havia no país 1,2 milhão de crianças e adolescentes ocupados, predominantemente $(60,0 \%)$ em atividades agrícolas. O resultado representou um decréscimo de 4,5\% para 4,0\% nessa faixa de idade.

Entre as crianças e jovens ocupados de 5 a 13 anos, 60\% exerciam trabalhos não-remunerados, $17,3 \%$ eram empregados ou trabalhadores domésticos e $16 \%$ eram trabalhadores para o próprio consumo e $6,7 \%$ eram trabalhadores por conta própria e empregadores. Na faixa de 14 ou 15 anos, predominavam os trabalhadores e empregados domésticos $(44,3 \%)$, seguidos por trabalhadores não-remunerados $(39,1 \%)$ (IBGE,2007).

Entre os adolescentes entre 16 e 17 anos, 66,3\% eram empregados ou trabalhadores domésticos e 21,3\% trabalhadores não-remunerados. Neste grupo que, de acordo com a legislação, pode trabalhar desde que não seja em atividades noturnas, perigosas e insalubres, cerca de 2,3 milhões estavam ocupados. O nível de ocupação nessa faixa etária manteve-se estável em 34,7\%, entre 2006 e 2007. 
Aproximadamente 636 mil estavam ocupados em atividades agrícolas. Verificou-se que o perfil desses trabalhadores adolescentes é o mesmo das faixas etárias citadas anteriormente: 63,5\% pertencem ao sexo masculino, 55,4\% à cor negra ou parda, e moram em domicílios com rendimento médio domiciliar per capita em torno de $\mathrm{R} \$$ 352,00 (Pnad,,2007).

Ainda conforme a pesquisa, no país, na passagem de 2006 para 2007, o percentual de crianças e adolescentes de 16 ou 17 anos de idade que estavam trabalhando como empregados ou trabalhadores domésticos e não tinham carteira assinada subiu de $79 \%$ para aproximadamente $87,4 \%$. Ao se traçar um perfil do trabalho infantil, verificou-se que $39,3 \%$ das crianças e jovens estavam em atividades agrícolas; predominava entre elas as do sexo masculino $(65,7 \%)$ e de cor negra ou parda $(59,5 \%)$. A maioria $(71,7 \%)$ vivia em domicílios sem rendimento ou com rendimento médio per capita de até um salário mínimo.

Embora o trabalho infantil tenha reflexos negativos nas taxas de freqüência à escola, verificou-se que, no grupo de crianças e adolescentes de 5 a 17 anos ocupados, a taxa de escolarização caiu de 81,0\%, em 2006, para 80,0\%, em 2007, enquanto entre os não-ocupados passou de $93,5 \%$ para $94 \%$. A taxa de escolarização é calculada considerando a percentagem dos estudantes de um grupo etário em relação ao total de pessoas do mesmo grupo (Pnad, 2007).

Os dados sobre escolarização mostram que, em 2007, do total de pessoas com quatro anos ou mais de idade no Brasil (190 milhões), cerca de 56,3 milhões eram estudantes. No contingente de jovens de 7 a 14 anos de idade, foi verificada a maior freqüência à escola (97,6\%), resultado estável em relação a 2006 (Pnad,2007). A pesquisa evidenciou que, no período de 1992 a 2007, a da taxa de escolarização das pessoas de 7 a 14 anos de idade aumentou 11,1 pontos percentuais, passando de $86,6 \%$ para 97,7\%, o que representa um contingente de, aproximadamente, 27 milhões de estudantes nessa faixa de idade em 2007.

Observou-se uma redução nas taxas de analfabetismo no país em 2007, embora estas ainda permaneçam elevadas, destacando-se os analfabetos funcionais. Os dados mostram que, nos últimos 15 anos, foram verificados avanços significativos na educação; a taxa de analfabetismo das pessoas com 15 anos ou mais 
em 1992 chegou a 17,2\%. De 2006 para 2007, a taxa de analfabetismo passou de 10,4\% para 10,0\%, o que representa cerca de 14,1 milhões de analfabetos com 15 anos ou mais de idade. A queda dessa taxa foi observada em todas as grandes regiões investigadas. Em 2007, 21,6\% das pessoas de 15 anos ou mais de idade eram analfabetas funcionais, contra $22,2 \%$ em 2006. Os estados do Norte e Nordeste tiveram as maiores taxas: $25,0 \%$ e $33,5 \%$, respectivamente (Pnad,2007).

Esses dados sugerem, portanto, que os jovens brasileiros enfrentam graves problemas de exclusão escolar, assim como necessidades e dificuldades frente ao mercado de trabalho. O mais alto grau de exclusão social se expressa na situação dos jovens que não estudam, não trabalham nem procuram emprego (14\% do total), um número próximo a 5 milhões de jovens brasileiros verificados na pesquisa promovida pelo Instituto Cidadania (2004). O percentual de adolescentes que está fora da escola, segundo o Ministério da Saúde (2000), é um indicador importante das condições de operacionalização da prevenção da violência nesse agrupamento social.

\subsubsection{A juventude e a violência no Brasil}

No que se refere à violência, as estatísticas mostram o seu crescimento nos grandes centros urbanos, envolvendo os jovens como vítimas ou agressores. Segundo SILVA (2002) uma estimativa da OMS mostra que 40 milhões de crianças entre 0 e 14 anos em todo o mundo sofrem abuso ou negligência e requerem cuidados sociais e de saúde. A pesquisa divulgada pela Unesco no Brasil mostra que em 2002 a taxa de homicídios na população jovem foi de 54,5 para cada 100 mil, contra 21,7 para o restante da população. A gravidade do problema é demonstrada pelo fato de a taxa no segmento juvenil ter aumentado de $30 \%$, no ano de 1980 , para $54,5 \%$, no ano de 2002, enquanto para o restante da população manteve-se estável.

Na revisão bibliográfica realizada, contatou-se que SOUZA (2003), no seu estudo denominado Análise Temporal da Mortalidade por Causas Externas no Brasil - Décadas de 80 e 90, mostra a importância da mortalidade por causas externas que, em 1998, já representava $15 \%$ de toda a mortalidade brasileira, com tendência estatisticamente crescente em suas taxas. Os adultos do sexo masculino eram os mais 
afetados, com crescimento de $18 \%$ nas taxas de mortalidade, no período estudado, respondendo por $83,6 \%$ das mortes por causas externas, com sobremortalidade de cinco óbitos para cada morte feminina. A autora salienta que as causas externas assumem considerável magnitude logo após o primeiro ano de vida, perfazendo $25 \%$ das mortes de crianças na faixa de 1 a 9 anos. Dos 10 aos 19 anos e dos 20 aos 29 anos, elas representavam quase $70 \%$ de todos os óbitos (p.103). O crescimento das causas externas, comprovado por dados de série histórica, mostra-se "mais acelerado nos grupos de 1 a 9 anos e de 10 aos 19 anos de idade, indicando a vitimização cada vez mais precoce dos cidadãos brasileiros" (SOUZA, 2003, p.104).

Segundo WAISELFISZ (2006), os dados do Sistema de Informações de Mortalidade do Ministério da Saúde - SIM/ MS permitem verificar que em 1980 as causas externas de mortalidade já eram responsáveis por aproximadamente metade $(52,9 \%)$ do total de mortes dos jovens do país. "Vinte e quatro anos depois, em 2004, dos 46.812 óbitos juvenis registrados no SIM/SVS/MS, 33.770 tiveram sua origem em causas externas, com esse percentual elevando-se de forma drástica: no ano de 2004 , quase $3 / 4$ de nossos jovens (72,1\%) morreram por causas externas" (p.21-22) .Verifica-se que na população adulta apenas 9,6\% do total de óbitos são atribuíveis a causas externas e só 3\% dos óbitos são ocasionados por homicídios, enquanto entre os jovens os homicídios são responsáveis por 39,7\% das mortes. (WAISELFISZ, 2006, p. 22).

Segundo SOUZA (2003), os homicídios e os acidentes de transportes foram, nessa ordem, as principais causas externas de mortalidade. No conjunto para o Brasil, elas constituíram 62,5\% de todas as causas externas, em 1998. A sobremortalidade masculina foi de 12:1 nos homicídios, e de 4:1 nos acidentes de transportes.Conforme documento do Conass (2007), no Brasil foram informados ao SIM/MS, 35.994 óbitos por acidentes de transporte terrestre. A maioria, assim como observados em relação aos homicídios e suicídios, ocorreu entre adultos jovens, de 20 a 39 anos $(44,9 \%)$ e do sexo masculino (81,9\%) (p.15).

A tendência tem sido o crescimento dos homicídios em todas as regiões, exceto no Sul do país, onde os suicídios se multiplicam. No Brasil, em 2005, a maioria dos óbitos por suicídio ocorreu em adultos jovens, de 20 a 39 anos, do sexo masculino. Porém, quando se considera a taxa específica de mortalidade segundo 
faixa etária, verifica-se que as maiores taxas se concentram na faixa etária de 60 anos e de 40 a 59 anos, com taxas respectivamente de 8,2 e 8,0 óbitos por 100 mil habitantes (Conass, p.15).

O crescimento dos homicídios na população jovem vem assumindo características de uma epidemia (SOUZA, 2003; SOARES, 2003). Segundo Relatório da Organização mundial de Saúde, a cada ano mais de 1,6 milhões de pessoas perdem a vida violentamente. No Brasil, os acidentes e as violências representam um problema de saúde pública de grande magnitude, com forte impacto sobre a mortalidade e a morbidade da população brasileira.

Entretanto, segundo WAISELFISZ (2006), em 2004 é possível verificar uma queda dos homicídios, relacionada com o Estatuto do Desarmamento, política pública aprovada em dezembro de 2003, conforme estudos realizados em que se utilizou cinco observações anuais anteriores ao desarmamento, referentes ao número de homicídios acontecidos entre 1999 e 2003, tabulados a partir do SIM/MS ( p.28).

Conforme o autor, o estudo permitiu verificar que em 17 das 27 Unidades Federadas (UF) do país, o número de homicídios em 2004 foi menor que o registrado em 2003. Estados como Roraima, Rio Grande do Norte e São Paulo destacam-se pelas quedas superiores a $15 \%$ (p. 29).

Entre os jovens, o impacto do desarmamento foi ainda maior, de acordo com o período estudado. A tendência histórica desde 1999 mostrou que a queda foi de 11,2\%, com destaque para Acre, Rio Grande do Norte e São Paulo, com quedas acima de $20 \%$ (p.29).

Considerando as capitais do país, o estudo mostrou que o aumento decenal de homicídios foi inferior ao experimentado nas unidades federais como um todo; no entanto, pode-se verificar que foram poupadas nas capitais 1.638 vidas que teriam sido vítimas de homicídio, das quais 826 foram vidas de jovens. A região metropolitana de São Paulo, desde 1999, vem apresentando quedas sistemáticas no número de homicídios. No total, os homicídios na população aumentaram 38,8\% na década, e os homicídios jovens cresceram 50,3\% (p.38).

Na cidade de São Paulo, a série Olhar São Paulo: violência e criminalidade, publicação da Secretaria Municipal de Planejamento (Sempla) traz a análise da violência e sugere que na capital os riscos de homicídio diminuíram muito, mas 
continuam a se concentrar nas mesmas áreas onde vêm ocorrendo há pelo menos duas décadas. A seqüência de mapas apresentada no documento ilustram o risco de homicídio doloso no Município de São Paulo, entre 2000 e 2005, e ressalta a tendência que se consolidou, ao longo dos últimos 25 anos, de estes homicídios apresentarem maior risco nos pontos mais extremos da cidade nas zonas Sul, Leste e Norte (SEMPLA, 2008, p.10).

Hoje se fala em "epidemia da violência", o que exige "a vigilância constante sobre a nossa liberdade e um olhar médico, sociológico, pedagógico, criminológico, principalmente sobre os homens, jovens, perpetradores e vítimas preferenciais" dessa situação (SCHILLING, 2004, p. 43-44). Geograficamente, esses eventos estão muito claramente definidos: são jovens moradores de regiões periféricas urbanas (p.51).

Segundo WAISELFISZ (2006), observam-se diferenças evidentes no número de óbitos por homicídio no ciclo de vida da população, sendo na faixa etária dos 15 aos 24 anos que os homicídios atingem maior expressividade, principalmente de 20 a 24 anos de idade, com taxas em torno de 65 homicídios por 100 mil jovens. Na faixa dos 14 aos 17 anos, porém, os homicídios vêm crescendo em ritmo assustador, com pico nos 14 anos, quando os homicídios, na década de 1994-2004, cresceram 63,1\%. No entanto, é dos 15 aos 29 anos de idade que as taxas mais se elevaram na década, com índices bastante diferenciados das restantes faixas etárias (p.53).

Quanto aos homicídios segundo sexo, tanto os estudos nacionais quanto internacionais (MELLO, 2002; MINAYO, 2003; UNICEF, 2003), alertam que as mortes por homicídio entre os jovens são ocorrências notadamente masculinas.

WAISELFISZ, 2006, analisando os dados disponibilizados pelo SIM/MS, mostra que só 7,9\% das vítimas dos homicídios acontecidos no país durante o ano de 2004 pertencem ao sexo feminino. Entre os jovens, essa proporção é ainda menor: 6,3\%. Essas proporções vêm se mantendo constantes nos últimos anos, com poucas variações em todas as Unidades Federadas (p.61).

Segundo o autor, conforme dados do Censo Demográfico do ano 2000 divulgados pelo IBGE, a taxa de homicídios, 'enormemente díspares' entre ambos os sexos, está gerando um forte desequilíbrio demográfico na distribuição por sexo da população, no país, principalmente a partir dos 20 anos de idade, só por homicídios, sem considerar os acidentes de transportes. Anualmente verifica-se a "perda'de um 
contingente de quase 40 mil homens, o que desequilibra a composição sexual da população adulta (p.62).

Portanto, conforme levantamento bibliográfico realizado,constatou-se que as faixas etárias que correspondem à juventude concentram o risco de vitimização letal, mas os indicadores variam conforme a região da cidade, do estado ou do país. Os autores ressaltam que as generalizações devem ser evitadas, quanto aos tipos de violência, aos locais e demais fatores geográficos, sociais e individuais. No entanto, o que não varia é o gênero da vítima: nos principais casos observados, os indivíduos do gênero masculino são os mais suscetíveis aos processos de vitimização (SOUZA, 2003; SOARES, 2003).

A pesquisa do Instituto de Cidadania, denominada Projeto Juventude (2004), revelou que $11 \%$ dos jovens já sofreram diferentes tipos de violência física; tendo a maior parte delas ocorrido em casa ou na vizinhança, cometida por familiares, parentes, namorados, ou conhecidos. Cerca de $20 \%$ dos jovens entrevistados já foram assaltados, enquanto $46 \%$ perderam algum parente ou amigo de forma violenta. A violência aparece como um dos principais fatores de preocupação dos jovens, citada em primeiro lugar, em diferentes níveis de renda, escolaridade, gênero e cor, como o problema mais importante.

MELLO JORGE et. al, já delineando há alguma tempo em seus estudos, o panorama brasileiro sobre violência, às crianças e jovens, em 2002 manifestaram uma grande preocupação ao escrever a seguinte frase, em um artigo científico sobre as questões relacionadas à juventude: "Vistos de forma isolada, os problemas que afligem esse grupo populacional mostram-se importantes e relevantes. Entretanto, analisados de maneira conjunta, tentando ver essas pessoas globalmente em seus aspectos de educação, trabalho, saúde, lazer e família, entre outros, evidenciam um quadro mínimo assustador, revelando que há muito por fazer" (MELLO JORGE et. al 2002, p.70).

Devido à relevância e à magnitude da violência social no país e na cidade de São Paulo, sendo os jovens as principais vítimas, como demonstram diversos estudos realizados, é que foi escolhido o tema desta tese. (ADORNO, 1991,1993; DESLANDES, 1994; GOMES, 1994; GUERRA, 1996; AGUDELO,1997; CRUZ NETO e MOREIRA,1999; MELLO,1999; SOUZA, 2001; UNESCO, 2002; 
WESTPHAL,2002; MINAYO, 2002, 2003; SPÓSITO, 2003; ASSIS, 2003, 1994; CARDIA,2003;SILVA，2003; INSTITUTO CIDADANIA, 2004; SCHILLING, 2004).

Assim, orientamos este trabalho de pesquisa para os objetivos que faremos conhecer a seguir, tendo como fundamento referenciais de análise específicos que aprofundaremos na sessão Referenciais Teóricos. 
OBJETIVOS 


\section{OBJETIVOS}

\subsection{OBJETIVO GERAL}

Analisar e comparar os processos que orientam as ações coletivas e as experiências participativas de promoção da saúde dos jovens, realizadas pelas organizações governamentais e não-governamentais para o enfrentamento e resistência à violência nos Distritos Administrativos do Grajaú e Jardim Ângela do município de São Paulo, visando contribuir para a construção de uma cultura de paz e implementação de políticas públicas para a juventude local.

\subsection{OBJETIVOS ESPECÍFICOS}

- Caracterizar as condições de vida e acesso a bens e serviços dos jovens residentes nos Distritos de Saúde do Grajaú e Jardim Ângela.

- Analisar as construções e percepções de ser jovem, violência e paz dos jovens das regiões de estudo.

- Identificar e analisar as construções sociais e as percepções das famílias, profissionais de saúde e educação, e representantes de instituições de apoio social à juventude local sobre: o que é ser jovem, as condições de vida e de desenvolvimento dos jovens e sua relação com a violência nas regiões de estudo.

- Identificar e analisar os sentidos de pertencimento, e os tipos de vínculos que os jovens estão construindo nas regiões de estudo, como forma de proteção ou de aumento dos riscos à violência .

- Identificar os projetos, as ações de promoção da saúde e de enfrentamento da violência juvenil nos Distritos de Saúde do Grajaú e Jardim Ângela e a integração entre eles na perspectiva da intersetorialidade.

- Identificar e analisar as redes de apoio para proteção e desenvolvimento dos jovens e proteção dos riscos da violência. 
REFERENCIAL TEÓRICO 


\section{OS JOVENS NO CONTEXTO DAS POLÍTICAS PÚBLICAS}

\subsection{A CONCEPÇÃO DE JUVENTUDE}

O tema juventude, devido à sua complexidade, pode ser analisado por diferentes perspectivas. A juventude, na sociedade moderna, está cada vez mais associada a um conjunto diversificado de modos de vida, do que a uma categoria de idade (PAIS, 2003, p.378).A juventude considerada uma categoria socialmente construída, em circunstâncias econômicas, sociais, e políticas particulares, pode-se modificar ao longo da história. Nessa perspectiva, visando resgatar as mudanças históricas e culturais que permearam as diferentes concepções, destacaremos alguns autores que contribuem para este debate.

Entre as questões que geram controvérsias nos estudos sobre a juventude, destaca-se "a falta de consenso e a diversidade de opiniões dos especialistas quanto à definição ou estabelecimento da faixa etária que compreende o ser jovem" Conforme a autora, "as faixas etárias são definidas de acordo com as dinâmicas regionais, contextos sociais e com as finalidades para cada demarcação"(ANDRADE, 2008, p.25).

A Organização Mundial de Saúde (OMS) circunscreve cronologicamente a adolescência ao ciclo de vida de 10 a 19 anos e a juventude ao período de 15 a 24 anos. Esses conceitos comportam desdobramentos, identificando-se adolescentes jovens de 15 a 19 anos e adultos jovens de 20 a 24 anos. O conceito de adolescência e juventude incorporado nos documentos internacionais adota a definição da OMS e essas faixas etárias são as mais utilizadas para delineamento de políticas e para definições legais em geral (MS, 2005). Neste estudo utilizaremos o termo jovem, para a faixa etária compreendida entre 10 e 19 anos.

No que se refere à concepção de juventude, há uma série de imagens a respeito dela que interferem na maneira de compreender os jovens. Uma das mais presentes no cotidiano é a dos jovens em sua transitoriedade. Nesta visão, o jovem é um "vir a ser", tendo no futuro o sentido das ações no presente. Essa concepção nega o presente vivido pelo jovem.

Uma outra visão é a da juventude como um tempo de liberdade, de prazer e de expressão de comportamentos exóticos. Considerada por diversos autores, entre 
eles DAYRELL(2003), como uma visão romântica que vem se cristalizando a partir da década de 1960, resultado de diferentes fatores, entre eles o florescimento da indústria cultural e de um mercado de consumo dirigido aos jovens. À esta visão está aliada a noção de moratória, na qual a juventude é vista como um tempo de ensaio e erro, de experimentações, considerado um período marcado pela irresponsabilidade, com a relativização de aplicações de sanções sobre o comportamento juvenil.

Essas visões convivem com outras como a da juventude considerada uma fase difícil, um momento de crise, dominada por conflitos com a auto-estima e/ou personalidade. Nesta visão, o jovem é tido como um "problema social". Os jovens são vistos como problema: de inserção profissional, de falta de participação social, de drogas, de delinqüência juvenil, na escola e com aos pais (PAIS, 2003,p. 34).Conforme o autor, esta versão foi dominante nas décadas de 1950 e 1960, com forte influência do funcionalismo, que considerava a adolescência como a crise de puberdade e juventude como um "período difícil" e, como veremos no desenvolvimento deste estudo, esta concepção ainda persiste no imaginário social dos atores entrevistados nos distritos administrativos do Jardim Ângela e do Grajaú.

Portanto usualmente a adolescência é definida como um período difícil da vida, marcado por um processo de crescimento físico e desenvolvimento psicossocial. É o momento em que o indivíduo se prepara para assumir responsabilidades próprias da idade adulta e plena autonomia social. Para os adultos, o adolescente é aquele que questiona tudo, fazendo-o sempre com muita ansiedade. A indulgência é a resposta de muitos pais durante todo o período de instabilidade. Segundo DOLTO (1990), “o estado de adolescência prolonga-se conforme as projeções dos adultos sobre os jovens e de acordo com o que a sociedade lhes impõe como limite de exploração” (DOLTO,1990, p.18).

Há ainda a visão que concebe a juventude como um momento de distanciamento da família, apontando para uma possível crise da família como instituição socializadora. Segundo DAYRELL (2003), alguns autores ressaltam que a família, o trabalho e a escola, estaria perdendo o papel central de orientação e valores para as gerações mais novas.

Construir uma concepção de juventude que consiga abranger a heterogeneidade do real é considerada por vários autores uma tarefa muito difícil. 
Segundo SPÓSITO (2003), "tem sido recorrente a importância de se tomar a idéia de juventude em seu plural - juventudes -, em virtude da diversidade de situações existenciais que afetam os sujeitos" (p.60).

"Construir uma noção de juventude na ótica da diversidade implica, em primeiro lugar, considerá-la não mais presa a critérios rígidos, mas sim como parte de um processo de crescimento totalizante, que ganha contornos específicos no conjunto das experiências vivenciadas pelos indivíduos no seu contexto social"'(DAYRELL, 2003, p.42).

A noção de juventude, pelo prisma da diversidade, considera o contexto de classe por meio da origem social, levando em conta as determinações sociais mais amplas e os diferentes sistemas de interações sociais e simbólicas que interferem na trajetória social dos jovens (DAYRELL, 2005, p.22). Segundo PERALVA (1997), a juventude é simultaneamente uma condição social e uma representação. A maioria das representações correntes trata a juventude como uma unidade social, um grupo dotado de interesses comuns, os quais se referem a uma determinada faixa etária (DAYRELL, 2005). Nesta perspectiva, a juventude assumiria um caráter universal e homogêneo. Por universal, consideram-se as transformações do indivíduo, em uma determinada faixa etária, nas quais ele completa seu desenvolvimento físico e enfrenta mudanças psicológicas. No entanto, em cada sociedade, e no interior de cada grupo social, há representações variadas desse momento, concretizadas nas condições sociais - estruturais, (classes sociais), culturais (etnias, identidades religiosas, valores), de gênero e outras.

Segundo DAYRELL (2005), a sociologia da juventude, no sentido de desnaturalizar esta noção e transformar a questão da juventude em um problema sociológico, tem sido debatida, sem conseguir, ainda, um denominador comum.

PAIS (1993) aponta duas vertentes, nas quais os estudos na área da sociologia da juventude têm oscilado. A primeira, denominada geracional, define a juventude como uma fase da vida, enfatizando a busca de aspectos característicos, uniformes e homogêneos que fariam parte de uma cultura juvenil, específica de uma geração definida em termos etários. Esta corrente abarca tanto as teorias da socialização quanto as sobre gerações. Numa segunda vertente, denominada classista, a juventude é considerada um conjunto social necessariamente diversificado, em razão das 
diferentes origens de classe, que apontam para uma diversidade das formas de reprodução social e cultural. "As culturas juvenis seriam exemplos de classes. Como produto das relações sociais antagônicas, expressariam sempre um significado político de resistência, ganhando e criando espaços culturais" (DAYRELL,2005, p.22).

Segundo ABAD (2003), se anteriormente a condição juvenil, como etapa vital entre a infância e a maturidade, estava mediada pelas relações de incorporação à vida adulta e de aquisição de experiência, vinculando-se a instituições de transição ao mundo adulto, hoje não se pode negar que "os jovens têm-se convertido numa categoria social, interclassista e comum a ambos os sexos, definida por uma condição específica que demarca interesses e necessidades próprias, desvinculadas da idéia de transição e suas instituições sociais" (ABAD, 2003, p.23).

Conforme ABRAMO (2003), a condição juvenil, nas últimas décadas, sofreu grandes transformações, tornando difícil afirmar que a juventude se resume na preparação para a vida adulta, futura. "A juventude se alargou no tempo e no espaço social, e ganhou uma série de conteúdos próprios" (p. 222). A juventude deixou de ser um momento breve de passagem, restrito às classes altas e médias. Já não pode mais ser definida exclusivamente pela condição estudantil, uma vez que a educação foi largamente expandida em diversos planos da vida social, inclusive no mundo do trabalho, na vida afetiva/sexual, na produção cultural, na participação social, entre outros. A juventude é "um momento de intensa experimentação e de construção de caminhos de participação na sociedade; é, ainda, um tempo de formação - mas não mais isolado da intensidade da vida social.”( p.222).

Neste estudo adotamos a noção de juventude sobre a ótica da diversidade. (SPÓSITO, 2003; DAYRELL, 2005), considerada socialmente construída e relacionada ao desenvolvimento da sociedade moderna.

\subsection{PARA COMPREENDER OS JOVENS}

Para entender os jovens, estudos como os de ARIÈS (2006), SANTOS, (1996) e COSTA (1983) têm evidenciado a transformação dos conceitos como família, infância, adolescência e sexualidade. Estes são considerados determinantes 
na construção dos sujeitos, mostrando que são definidos e construídos historicamente, dando lugar a uma compreensão histórico-social.

Estudos como de ABAD (2003, p.23), sobre o complexo processo de desinstitucionalização da juventude atual, apontam alguns fatores responsáveis por essa nova realidade:

- A crise da família tradicional e a multiplicação das novas formas de família questionando e recolocando limites e novas funções entre pais e filhos. As relações paterno-familiares hoje fundamentadas muito mais, na tolerância, na negociação e na sedução, do que nos padrões rígidos da autoridade paternal e de obediência filial.

- O esgotamento da ilusão da mobilidade social e da ascensão social, depositada na expansão da educação secundária e universitária, vinculada à modernização industrial, à economia em crescimento e à esperança de pleno emprego.

- A emergência massificada, plural e intensa de novos atores sociais, entre eles os jovens, exercendo pressão para formulação de políticas sociais, reformas legislativas e novos contratos sociais para reconhecer $\mathrm{e}$ atender as necessidades específicas e as dimensões da nova condição juvenil.

- A dissolução das identidades ligadas à idéia de Nação, ou Território, com desajuste de crenças e valores tradicionais, devido ao processo de globalização, que impossibilita o projeto populista de uma reprodução estável e ordenada de uma cultura 'nacional' para as novas gerações.

Conforme DAYRELL (2005), pensar os jovens no Brasil implica considerar a enorme diversidade contextual e sociocultural características do país neste momento histórico. Esta diversidade é acentuada no contexto de crise pela qual passa a sociedade brasileira, com reflexos nas instituições tradicionalmente responsáveis pela socialização, como o trabalho e a escola, dentre outros. Essa crise é vivida de forma diferenciada pelos jovens. Aqueles que se encontram no limiar da precariedade vivenciam-na de forma mais profunda.

O trabalho está deixando de ser uma atividade de produção de valores. Segundo relatório da Organização Internacional do Trabalho (OIT, 2006), um em 
cada cinco jovens não trabalha nem estuda na América Latina. Dos 106 milhões de jovens de 15 a 24 anos, 22 milhões estão nessa situação. O relatório ainda revela que 31 milhões de jovens empregados trabalham em atividades consideradas 'precárias'. Embora tenha havido redução do desemprego entre adultos, houve aumento entre os jovens. Os dados mostram que $6 \%$ dos adultos estão desempregados. Entre os jovens, o índice é quase o triplo: 17\%. Dos 22 milhões dos jovens que não trabalham nem estudam, $72 \%$ são mulheres. Às jovens são atribuídas as responsabilidades pelo trabalho doméstico e uma parte dessas jovens são mães. Para as jovens, a gravidez precoce significa a impossibilidade de estudar e trabalhar. São estes os jovens com mais dificuldades de acesso à escola.

Não obstante o aumento real das taxas de escolarização, nos últimos 20 anos tem-se constatado um quadro de desigualdade de acesso, principalmente na permanência escolar, uma vez que apenas $24,8 \%$ têm o equivalente ao ensino fundamental ou mais. Assim como no trabalho, para essa parcela da população a escola parece não constituir uma referência de valores na construção dos jovens como sujeitos (DAYRELL, 2005, p.23).

Contribuem para o agravamento da situação, na esfera pública, as políticas que não contemplam as necessidades, as potencialidades e as especificidades das identidades sociais dos diferentes segmentos juvenis e o fortalecimento das famílias. Conforme revelado no presente estudo, os jovens pesquisados atribuem relevância à família, à escola e ao trabalho. Apesar da situação de vulnerabilidade na qual a família se encontra, ela ainda é considerada um espaço privilegiado de socialização, contribuindo para a prática de tolerância, divisão de responsabilidades, de busca coletiva de estratégias de sobrevivência e lugar inicial para o exercício da cidadania.

\subsection{O JOVEM E O MARCO JURÍDICO INTERNACIONAL}

Para orientar e gerir políticas, a sociedade brasileira tem buscado orientação na fixação de ciclos de vida, que indicam estágios de desenvolvimento humano e estabelecem necessidades e características específicas e comuns aos segmentos da população. A adoção do critério cronológico vem sendo considerado um meio eficiente para a elaboração de estratégias e políticas públicas de desenvolvimento coletivo (VENTURA,2005). 
No âmbito jurídico, não há uma definição internacional sobre o que é ser adolescente. A Convenção Internacional sobre os Direitos da Criança define criança de forma genérica, como tal, até os 18 anos.

No contexto Internacional, a Declaração Universal dos Direitos Humanos, firmada pela Organização das Nações Unidas (ONU,1948), orienta o estabelecimento de uma série de convenções. Através delas tem sido criados estatutos comuns de cooperação mútua e mecanismos de controle, visando garantir a não violação e o exercício de um elenco de direitos básicos à vida digna, ou seja, os direitos humanos. Desde então, estas convenções tem se alterado e ampliado conforme as novas condições sociais, originando diversos pactos genéricos e específicos.

No ano de 1996, nos Pactos Internacionais de Direitos Civis e Políticos e de Direitos Econômicos, Sociais e Culturais, foram reconhecidos direitos humanos universais no plano individual, coletivo e social, entre eles, o direito à saúde e o direito da criança à especial proteção do Estado, da sociedade e da família, comprometendo-se as nações signatárias a garanti-los e implementá-los.

Para concretizar os direitos universais, houve a necessidade de criar medidas específicas dirigidas a segmentos mais vulneráveis às violações de seus direitos para a garantia da igualdade concebida. Criou-se então um sistema de proteção que destaca alguns sujeitos, como os negros, as mulheres, as crianças, os adolescentes, os idosos e os deficientes, que se materializou nas diversas Convenções firmadas pela Nações Unidas, entre elas sobre os direitos da criança, adotada em 20/11/1989 e ratificada pelo Brasil em 24 de setembro de 1990. Dessa forma, os estados passaram a ser obrigados a implementar políticas públicas que considerem as diferenças e as vulnerabilidades dos sujeitos de direitos nos diversos contextos sociais, visando à redução das desigualdades e à promoção de uma vida digna.

A Convenção dos Direitos da Criança, adotada pela Assembléia Geral das Nações Unidas (ONU, 1989), é um importante instrumento de proteção dos direitos humanos das crianças e dos adolescentes, de ambos os sexos. Reconhece a criança e os adolescentes como sujeitos sociais, portadores de direitos e de garantias próprias, independentemente da intervenção da família, do Estado e da sociedade, ocorrendo assim, uma importante mudança de paradigma. Estabelece obrigações diferenciadas 
para o Estado, para as famílias e para a sociedade em geral, além de introduzir, no plano normativo, as seguintes questões relacionadas à criança e ao adolescente:

- o valor intrínseco da criança e do adolescente como ser humano;

- a necessidade de especial respeito à sua condição de pessoa em desenvolvimento;

- o reconhecimento como sujeitos de direitos; e

- $\quad$ sua prioridade absoluta nas políticas públicas.

Os direitos sexuais e os direitos reprodutivos dos adolescentes têm se revelado polêmicos. As Conferências Internacionais mais recentes, como a Conferência Internacional de População e Desenvolvimento (CAIRO, 1994), a Conferência Internacional sobre as Mulheres (PEQUIM, 1995) e, recentemente, a decisão do Comitê dos Direitos da Criança, responsável pelo monitoramento da Convenção Internacional sobre os Direitos da Criança (CRC/GC/2003/4), têm dedicado maior atenção às necessidades e aos problemas de saúde reprodutiva e sexual dos adolescentes, aprovando consensos e reconhecendo explicitamente que "o direito de desfrutar do mais alto nível possível de saúde física e mental" inclui o direito à saúde sexual e reprodutiva (VENTURA, 2005).

O Plano de Ação da Conferência Mundial de População e Desenvolvimento (CAIRO,1994), que introduziu na normativa internacional o conceito de direitos sexuais e direitos reprodutivos, inseriu os adolescentes como sujeitos que deverão ser incluídos pelas normas, programas e políticas públicas. A Plataforma de Ação da IV Conferência Mundial da Mulher (PEQUIM, 1995), reiterou a definição e trouxe recomendações importantes sobre a violência sexual e estrutural bem como suas repercussões na saúde da mulher e das meninas. A necessidade de alterar as leis que prevêem medidas punitivas contra mulheres que se tenham submetido a abortos ilegais é um dos exemplos das repercussões na saúde de mulheres e adolescentes.

No processo de revisão e avaliação da implementação do programa Cairo + 5, realizado pela ONU em 1999, outros avanços podem ser identificados. Nessa revisão, foi garantido o direito dos adolescentes à privacidade, ao sigilo, ao consentimento informado, à educação, inclusive sexual no currículo escolar, à informação e à assistência à saúde sexual e reprodutiva (CORREA, 2000). 
Conforme o documento "Marco Legal: Saúde, um direito dos adolescentes", do Ministério da Saúde (2005), o Brasil tem participado ativamente nos planos internacional e nacional das lutas em prol dos direitos humanos. A Constituição Brasileira elegeu como um dos princípios norteadores das relações internacionais e nacionais a prevalência desses direitos. Portanto, o cumprimento das obrigações internacionais assumidas e o reordenamento dos marcos jurídico-institucionais, de acordo com as exigências das Convenções Internacionais de Direitos Humanos estão previstos na nossa Constituição.

\subsection{O JOVEM E O MARCO JURÍDICO NACIONAL}

No contexto brasileiro, destacam-se iniciativas importantes, como a aprovação do Estatuto da Criança e do Adolescente, em 13 de julho de 1990 pelo poder Legislativo, incorporando integralmente todos os princípios e normas da Convenção sobre Direitos da Criança adotada pelas Nações Unidas em 20 de novembro de 1989.

$\mathrm{O}$ acesso da criança e do adolescente foi reformulado a partir do Estatuto, com a criação da Justiça da Infância e da Juventude no âmbito dos poderes judiciários estaduais, além de mecanismos e procedimentos próprios de proteção judicial e extrajudicial dos interesses individuais, difusos e coletivos das crianças e adolescentes: Dentre as medidas adotadas, destacam-se:

- Os Conselhos Tutelares, que têm, entre suas competências, o poder para requisitar serviços públicos necessários às autoridades competentes; atender e aconselhar adolescentes, expedir notificações quando houver descumprimento do Estatuto, assessorar o poder Executivo local na elaboração da proposta orçamentária.

- A legitimidade das associações de defesa dos interesses da criança e dos adolescentes legalmente constituídas e do Ministério Público, para pleitear junto à Justiça da Infância e da Juventude os direitos à assistência social, ausências ou insuficiências dos serviços de saúde, de atendimento educacional básico e especializados aos portadores de deficiência, entre outros. 
- A obrigatoriedade das equipes de saúde e educação de comunicar ao Conselho Tutelar casos de suspeita ou confirmação de maus-tratos contra a criança e o adolescente, para providências e intervenções legais cabíveis.

O Conselho Nacional dos Direitos da Criança e do Adolescente - Conanda, estabeleceu algumas diretrizes nacionais para o período de 2001 a 2005, a fim de direcionar os procedimentos nas áreas das políticas sociais e temas focais que orientarão a organização, a articulação, o desenvolvimento e avaliação de programas, executados pelos órgãos governamentais e pela sociedade civil (CONANDA,2001). O uso abusivo de drogas e a questão da saúde sexual e reprodutiva estão incluídas nas diretrizes estabelecidas pelo Conanda para o período de 2001 a 2005. Entre as estratégias, está o cumprimento dos parâmetros curriculares do sistema educacional, incluindo o tópico sobre orientação sexual. O Conanda recomenda para o setor saúde esforços na implementação de programas de serviços de atenção integral à saúde do adolescente, privilegiando a orientação sexual com vistas à prevenção da gravidez e das DST/Aids, bem como o tratamento para os usuários de substâncias psicoativas (VENTURA, 2005).

Também merecem destaque:

- O lançamento do Programa Nacional de Direitos Humanos (PNHD), por meio do Decreto Presidencial n. ${ }^{\circ}$ 1.904/1996, atualmente em sua segunda fase (PNH II), no qual o governo brasileiro se compromete a implementar as decisões das Conferências Mundiais e demais atos internacionais, incorporando no Plano Nacional compromissos para crianças e adolescentes, como a prevenção e a punição severa da exploração sexual, os programas especiais para redução da violência doméstica, do uso de drogas, e as ações que eliminem o trabalho infantil e punam sua prática.

- Lei Orgânica da Saúde - Lei n. 8.080/1990, que regulamenta a disposição constitucional que concebeu a saúde como um direito social, independentemente de contribuição, criando o Sistema Único de Saúde (SUS).

- Lei Orgânica da Assistência Social - LOAS - Lei n. 8.742/1993, que regulamenta o direito constitucional (art. 203) à assistência social do Estado, 
independentemente da contribuição, e garante expressamente a proteção especial à adolescência e ao amparo aos adolescentes carentes.

- Lei de Diretrizes e Bases da Educação Brasileira - LDB - Lei n.॰ 9.394/1996, que regulamenta o direito à educação também como direito público subjetivo de todo cidadão.

As legislações citadas têm em comum a descentralização política e administrativa, enfatizando as competências dos municípios, e a participação da sociedade para formulação das políticas. "Esse novo marco conceitual e legal de política pública vem instrumentalizar e possibilitar uma melhor articulação institucional e o desenvolvimento de programas e ações que dêem conta da realidade local, sem perder de vista a proposta nacional" (MS, 2005, p.31).

No entanto, conforme SPÓSITO (2003), apesar das conquistas, consagradas em legislação específicas, as novas orientações continuam situadas em um campo de conflito intenso, "pois concepções anteriormente firmadas continuam a existir e sempre podem estabelecer limites às conquistas e impor retrocessos até de natureza legal". Nesse sentido, SPÓSITO (2003, p.63) cita dois exemplos recentes "que evidenciam essa possibilidade de recusa das conquistas anteriores": as propostas em andamento, que buscam alterar a idade mínima para imputar responsabilidade legal aos adolescentes e a defesa de um sistema prisional para os adolescentes semelhantes aos dos adultos.

Conforme SPÓSITO (2003), a dupla natureza de conflito das políticas públicas de juventude:

incide, assim, sobre a arena pública no campo das orientações-percepções sobre a condição juvenil - e sobre o modo de interação entre o poder público e a sociedade civil, mais ou menos aberto à participação democrática e não tutelada dos segmentos juvenis, sendo assim, a possibilidade de uma qualificação da política freqüentemente utilizada - se é 'para', "por meio de' ou 'com os jovens' - não pode ser examinada de modo ingênuo (SPÓSITO, 2003, p.64).

Essa qualificação do agir político é decorrente das concepções dominantes sobre a condição juvenil e das interações entre governo e sociedade. Nessa dupla perspectiva, as considerações podem ser variadas: percepções avançadas sobre direitos de juventude não aparecem quando o modo dominante de formulação de políticas e de interação com a sociedade civil não constitui espaços de interlocução 
democrática. Entretanto, mesmo com o caráter democrático de algumas administrações, os segmentos juvenis ainda são concebidos como ameaças e foco de problemas, necessitando ações de tutela ou proteção. Assim pensando, deixam de constituir espaços de desenvolvimento da autonomia dos jovens, como atores coletivos (SPÓSITO, 2003 p.64). 


\section{CONCEITUANDO A VIOLÊNCIA}

Definir violência não é uma tarefa fácil, querer determinar a noção de violência de maneira fixa e simples significa reduzi-la a uma compreensão equivocada de sua evolução e especificidade histórica.

Segundo MINAYO (2003), a violência não é uma, é múltipla. De origem latina, o vocábulo origina-se da palavra vis, que quer dizer "força" e se refere às noções de constrangimento e de uso da superioridade física sobre o outro. Embora, do ponto de vista material, o termo pareça ser neutro, ao se analisarem os eventos violentos verifica-se que eles se referem a conflitos de autoridade, a lutas pelo poder e à busca de domínio e aniquilamento do outro, em que suas manifestações são aprovadas ou desaprovadas, lícitas ou ilícitas, segundo normas sociais mantidas por aparatos legais da sociedade ou por usos e costumes naturalizados.

"Mutante, a violência designa, pois - de acordo com épocas, locais, circunstâncias -, realidades muito diferentes. Há violências toleradas e violências condenadas. E, desde o nascimento do Homo sapiens e, mais especificamente, desde o início da modernidade, ela se enriquece de novas formas, cada vez mais complexas e, ao mesmo tempo, mais fragmentadas e articuladas" (MINAYO, 2003, p.25).

A dificuldade para conceituar violência "provêm do fato de se tratar de um fenômeno da ordem do vivido (no qual se inclui também quem tenta teorizar sobre ela) e cujas manifestações provocam uma forte carga emocional em quem a comete, em quem a sofre, e em quem a presencia" (MINAYO, 2003, p.26).

Segundo MINAYO (2003), entre as contribuições para a reflexão sobre o assunto, destacam-se as abordagens da visão do senso comum e do conhecimento erudito: as contribuições de filósofos e cientistas. Ressalta-se que a violência, mesmo quando fundamentada teoricamente, também implica julgamento social (MINAYO, 2003).

O termo violência colocado no seu plural distingue-se no discurso contemporâneo e no imaginário social, conforme (MINAYO, 2003; CHESNAIS, 1981). Segundo esses autores, há três definições implícitas no âmbito individual e coletivo: no centro de tudo, está a violência física, atingindo diretamente a 
integridade corporal, traduzida nos homicídios, agressões, violações, roubos a mão armada; em segundo plano, a violência econômica, que consiste no desrespeito e na apropriação, contra a vontade do dono ou de forma agressiva, de algo de sua propriedade e de seus bens. Em terceiro lugar, a violência moral e simbólica, que trata da dominação cultural, ofendendo a dignidade e desrespeitando os direitos do outro (MINAYO, 2003, p.26).

Segundo MINAYO (2006), do ponto de vista filosófico e sociológico, há pelo menos três fontes explicativas para a violência. Uma delas a considera como expressão de crises sociais, que levam a população mais atingida negativamente à revolta frente à sociedade ou Estado, uma vez que estes não conseguem responder adequadamente às necessidades sociais. A segunda refere-se ao caráter racional e instrumental da violência que a considera um meio para atingir fins específicos. Diferentemente da primeira explicação, que trata dos atores como vítimas, esta definição considera a pessoa violenta um ser consciente atuando no campo das interações. E, por último, ressalta-se a forte articulação entre violência e cultura, apoiada, sobretudo, na obra de NOBERT ELIAS (1993) e FREUD (1980).

ARENDT (2006) considera a violência um meio e um instrumento para a conquista do poder, no entanto, conforme a autora, não se deve confundir poder e violência; pelo contrário, ela ressalta que só existe violência quando há incapacidade de argumentação e convencimento. Desse modo, caracteriza a violência como instrumental, diferenciando-a do poder. O poder, para a autora, é a capacidade de agir em conjunto; nunca é propriedade de um indivíduo, pertence a um grupo e permanece em existência apenas na medida em que o grupo se mantém unido.

$\mathrm{Na}$ vertente da articulação entre violência e cultura, NOBERT ELIAS (1993) afirma que o papel civilizatório da modernidade criou mecanismos de institucionalização e solução de conflitos, levando os indivíduos a dominarem a agressividade e as pulsões violentas. Neste sentido também se destaca FREUD (1980) que apresenta várias interpretações da violência nas diferentes etapas do seu pensamento.

FREUD em sua obra Mal-estar na civilização, relaciona à violência à agressividade instintiva do ser humano. O autor considera os instintos destrutivos humanos responsáveis pelo mal-estar da civilização e mantém o ponto de vista de 
que a agressividade constitui uma disposição instintiva primitiva e autônoma do ser humano. COSTA (2003), como psicanalista, corrobora esta visão e afirma que "a violência não tem outra causa senão a satisfação dos impulsos e desejos destrutivos do homem. "Os motivos 'vis' ou 'nobres' são racionalizações (no sentido psicanalítico), destinadas à justificar, perante a consciência, a existência dessa destrutividade" (p.31).

Ainda na visão psicanalítica, a violência surge como conseqüência do conflito de interesses. Para COSTA (2003), ela é " um instrumento de que se servem os homens para arbitrar conflitos de interesses"(p.31). Esta também se articula no contexto da paz e do pacifismo. "Reiteradamente, definida como inevitável, como instrumento imprescindível à organização social., por fazer parte da agressividade instintiva do indivíduo, a violência, subitamente, aparece como domesticável pela ação da civilização" (p.33).

Destaca-se, ainda do ponto de vista erudito, a contribuição de DOMENACH (1981), para a compreensão da violência. Para o autor, a violência está inscrita nas relações sociais, e é constituída, principalmente, no interior das consciências e das subjetividades. De acordo com essa visão, a violência não pode ser considerada apenas uma força exterior aos indivíduos, diferentemente da concepção do senso comum, que costuma encará-la como um fenômeno produzido pelo "outro". Para o autor, a violência, no aspecto ontológico, não pode ser dissociada da condição humana e reforça a idéia de que ela deve ser analisada dentro da sociedade que a produz em sua especificidade interna e em sua particularidade histórica.

Uma outra importante contribuição é a de WIEVIORKA (2006), que procura esboçar uma teoria da violência com base na noção de sujeito. Nesta perspectiva, a pré- condição necessária, segundo o autor, é entender a noção de sujeito."O sujeito é a capacidade de construir a si próprio, de proceder escolhas, de produzir a sua própria existência. (...) É a capacidade de engajar-se e também desengajar-se. E só existe o sujeito no reconhecimento do Outro, na aceitação da alteridade" (WIEVIORKA, 2006, p.203). É uma dimensão da pessoa, distinta do indivíduo, que é definido não pela 'produção de si mesmo', mas pelo consumo e pelo acesso ao dinheiro. O sujeito é uma categoria abstrata que encontra na ação a sua realização 
mais importante. $\mathrm{O}$ sujeito não se torna sempre ou facilmente um ator e é no espaço que separa o sujeito do ator que se esboça a violência (WIEVIORKA, 2006, p.203).

Segundo WIEVIORKA (2006) "a violência é freqüentemente, ao menos em parte ou na origem, a marca de um sujeito contrariado, interditado, impossível ou infeliz"(p.203).

Ao analisar as experiências das violências urbanas, o autor integra o tema da frustração. A violência pode proceder de uma frustração, "no sentido em que uma pessoa ou um grupo se vê privado ou interditado de acesso a bens materiais ou a um reconhecimento simbólico legítimos" (p.203). Para o autor, a frustração "parece remeter mais ao indivíduo preocupado em consumir do que ao sujeito que se esforça para construir-se, e sobretudo desde que associe a frustração ao tema do reconhecimento, concebemos rapidamente a importância do lugar do sujeito" (p.203).

O sujeito tem mais chance de se construir e se exprimir, quando participa ativamente de relações, inclusive e sobretudo quando estas se dão na ordem do conflito. WIEVIORKA (2006) aponta a necessidade de distinguir conflito de violência. O conflito remete a uma relação estruturada de maneira mais ou menos estável e durável. "Os atores quando se opõem em um conflito são adversários e não inimigos; mesmo se nem tudo é negociável num conflito, este é o contrário da violência, que fecha o espaço de discussão e do debate, a favor da ruptura ou da relação de forças" (p.207) . No entanto, não basta dizer que a violência é o contrário do conflito, ou fruto da crise - social, política, econômica. Para o autor, o essencial é dizer que ela "coloca em ação um sentido, mas que este, inevitavelmente, perde-se, desnatura-se, perverte-se e sobrecarrega-se nela, o que é marca do trabalho do sujeito através da violência, onde ele é suprimido, (...) mas que, também, por vezes se funda" (p.212). Existe, em toda experiência concreta onde a violência intervém, uma parte de excesso ou de falta, em relação ao que poderia ser a experiência, se a violência estivesse ausente (p.212).

Considerando que a violência é caracterizada pela perda do sentido, se for o caso de recomendar políticas públicas de integração, segundo (WIEVIORKA (2006): 
suscetíveis de incluir os excluídos, ou de liquidar as frustrações relativas dos mais radicais, é preciso insistir então nas necessidades de políticas de reconhecimento, nas quais o problema consiste em articular esforços para satisfazer demandas ou expectativas de ordem econômica e social, bem como outras políticas que permitam cessar de desqualificar indivíduos e grupos, pelo desprezo e a discriminação social e racista (p.220).

Uma política do sujeito, para o autor, passa por medidas de eqüidade e de reconhecimento cultural, e pode demandar esforços de mediação e de restauração da comunicação rompendo com as lógicas de ruptura.

Segundo WIEVIORKA (2006, p.223), ao se pensar a violência com referência ao sujeito, do ponto de vista do ator ou da vítima, não é possível desconsiderar que as condutas humanas se desenvolvem no seio de sistemas sociais, políticos e culturais, e não apenas nos choques de subjetividades. Porém, considerando que, ao sair de uma época que a reflexão geral, ou relacionada à violência em particular, houve a tendência a desinteressar-se do sujeito, e até de proclamar a sua morte, e quando manifestadamente se assiste, em toda a parte, ao retorno do sujeito, pensar a violência na perspectiva do sujeito possibilita criar condições para melhor refletir sobre o fenômeno e sobre os meios de enfrentá-la.

\subsection{AS TIPOLOGIAS DA VIOLÊNCIA}

A Organização Mundial de Saúde (OMS, 2002) define a violência como "O uso intencional da força física ou do poder, real ou em ameaça, contra si próprio, contra outra pessoa, ou contra um grupo ou comunidade, que resulte ou tenha grande possibilidade de resultar em lesão, morte, dano psicológico, deficiência de desenvolvimento ou privação" (p.5). Esta definição associa-se intencionalidade com a prática do ato propriamente dito, independentemente do resultado produzido. Os incidentes não-intencionais - como a maioria das lesões de trânsito e queimaduras acidentais - estão excluídos da definição (OMS, 2002).

A definição, segundo a OMS (2002), inclui implicitamente todos os atos de violência, públicos, privados, sejam reativos (em respostas a eventos anteriores, como provocações) sejam pró-ativos (instrumental para resultados em beneficio próprio). Ressalta-se que cada um desses aspectos é importante para compreender as causas da violência e elaborar programas de prevenção a ela. 
A resolução World Health Assembly (WHA-49.25), de 1996, declara a violência como um dos principais problemas de saúde pública. Em decorrência disso, a OMS se propõe a elaborar uma tipologia para caracterizar os diferentes tipos de violência, bem como os vínculos existentes entre eles. Essa tipologia foi apresentada no Relatório Mundial sobre Violência e Saúde de 2002.

A tipologia elaborada pela OMS (2002) classificou a violência em três grandes categorias, com subcategorias, conforme as características de quem comete $o$ ato de violência:

\section{Violência dirigida a si mesmo - auto-infligida}

A violência auto-infligida é dividida em: comportamento suicida e autoabuso.

- Comportamento suicida: inclui pensamentos suicidas, tentativas de suicídio - também chamadas de "para-suicídios" ou "auto-lesão deliberada" em alguns países - e suicídios completados.

- Auto-abuso: inclui atos de mutilação.

2. Violência interpessoal: com duas subcategorias:

- Violência da família e de parceiro(a) íntimo(a): violência que ocorre entre os membros da família e parceiros íntimos, mas não exclusivamente dentro de casa. Compreende formas de violência como abuso infantil, violência praticada por parceiro íntimo e abuso contra idosos.

- Violência comunitária - ocorre entre as pessoas sem laços de parentesco (consangüíneos ou não, conhecidos ou não) geralmente fora de casa. Compreende atos aleatórios de violência, estupro ou ataque sexual por estranhos, bem como a violência em grupos institucionais, como escolas, local de trabalho, prisões e asilos (OMS, 2002).

3. Violência Coletiva: subdivide-se em violência social, política e econômica. As subcategorias da violência coletiva sugerem a existência de motivos possíveis para a violência cometida pelos grandes grupos de pessoas e Estados.

- violência social inclui, por exemplo, crimes de ódio cometidos por grupos organizados, atos terroristas e violência de multidões. 
- violência política inclui guerras e conflitos pertinentes, violência do Estado e atos semelhantes realizados por grupos maiores.

- violência econômica inclui ataques de grupos maiores motivados pelo ganho econômico, como negar acesso a serviços essenciais ou criar segmentações e fragmentações econômicas.

Ainda segundo a OMS (2002), a natureza dos atos violentos pode ser física, sexual, psicológica e privação ou negligências. Estes quatros tipos de atos violentos ocorrem em cada uma das grandes categorias e de suas subcategorias descritas, exceto a violência auto-infligida (p.6).

Outra forma de categorizar a violência é a proposta por MINAYO e SOUZA, 1999. Embora a violência seja considerada um fenômeno de difícil apreensão pelo grau de subjetividade, polissemia, polêmica e controvérsia que contém, ela pode ser analisada em suas formas e expressões como violência estrutural, violência doméstica e violência infanto-juvenil .

\section{Violência estrutural:}

é aquela que incide sobre a condição de vida das crianças e adolescentes, a partir de decisões histórico-econômicas e sociais, tornando vulnerável o seu crescimento e desenvolvimento. Por ter um caráter de perenidade e se apresentar sem a intervenção imediata dos indivíduos, essa forma de violência parece 'naturalizada', como se não houvesse nela a ação de sujeitos (MINAYO: 2202, p. 99).

2. Violência doméstica: é aquela exercida contra a criança e o adolescente na esfera privada (ASSIS, 1994; DESLANDES, 1994). Apresenta quatro tipos de expressões, mais visíveis, da mesma forma que OMS (2002), havia classificado:

- Violência física: "uso da força física contra a criança e o adolescente, causando-lhes desde uma leve dor, passando por danos e ferimentos de média gravidade, até tentativa ou execução do homicídio" (MINAYO, 2002, p.103).

- Violência sexual: "configura-se como todo ato ou jogo sexual, relação hetero ou homossexual entre um adulto (ou mais) com uma criança ou adolescente, tendo por finalidade estimulá-los sexualmente ou obter estímulo para si ou 
outrem" (ASSIS, 1993; GOMES, 1994; DESLANDES, 1994; GUERRA, 1996.).

- Violência psicológica: "também denominada tortura psicológica, ocorre quando os adultos sistematicamente depreciam as crianças, bloqueiam seus esforços de auto-estima e realização, ou as ameaçam de abandono e crueldade" (MINAYO, 2002, p.105).

- A negligência: "representa uma omissão em relação às obrigações da família e da sociedade de proverem as necessidades físicas e emocionais de uma criança" (MINAYO, 2002, p.106). Caracteriza-se pela falta de alimentos, de vestimenta, e cuidados escolares e com a saúde, quando estas falhas não resultam de circunstâncias fora do controle e alcance dos responsáveis pelos adolescentes e crianças.

3. Violência Infanto-Juvenil: Comumente tratada como delinqüência infantojuvenil, pela imprensa nacional e mundial. Segundo MINAYO (2002) em uma sociedade com tantas desigualdades sociais como a nossa, "o reconhecimento das crianças e jovens como transgressores necessita ser analisado com cuidado, porque esse fenômeno aparece quase sempre associado à questão de classe e atribuído aos pobres, principalmente aos meninos e meninas que perambulam ou trabalham nas ruas ou que são institucionalizados" (p.107).

Segundo a autora, ao preconceito junta-se a situação precária de qualquer projeto de vida. Ela argumenta:

Nos grandes centros urbanos, as alternativas são a indústria da droga (90\% dos delitos graves cometidos por adolescentes têm ligação com drogas), o subemprego, ou empregos considerados desqualificados. É por isso que se propõe tratar as transgressões sempre de modo articulado à violência estrutural, inclusive porque os dados infracionais costumam ser usados como álibi para extermínios, execuções e homicídios (p.107).

\subsection{AS DIMENSÕES DA VIOLÊNCIA}

A violência tem como característica fundamental "a capacidade de quebrar discursos prontos e colocar a questão do ordenamento até então aparentemente 
definidos. Assim em última instância a violência 'emudece'.” (SCHILLING, 2004, p.210). Essa característica aparece mais claramente nos casos da violência física, manifestando-se também em situações de agressão verbal e nos diversos casos de violência simbólica expressos no cotidiano. Segundo a autora, após a quebra dos discursos produzidos pela violência, procura-se "resistir, recriar, organizar novas falas sobre ela, mas enquanto está em curso, ela provoca o emudecimento" (p. 211). Sendo assim, quando for possível ouvir os danos provocados pela violência será preciso "reparar" -o que implica notar, perceber; e reconstruir, fazer algo em relação ao dano e, se possível, evitar a sua repetição (p. 212).

É nessa perspectiva que apresentamos as dimensões da violência conforme (SCHILLING, 2004, p.212-216):

1- Rejeitar a Cultura da violência: nesta dimensão a escola tem papel fundamental, pois nas relações cotidianas a escola poderá contribuir para a construção da cultura de paz e não-violência.

2- Dimensão econômica: materializada pela indústria do medo e da insegurança, presente no cenário político mundial, exemplificada pela idéia da guerra vista como negócio e como prevenção; a atuação da indústria bélica com a rápida e dinâmica renovação de produtos no mercado; as estratégias de ocultamento de problemas relacionados à recessão; entre outros.

3- A criminalidade urbana: causa maior repercussão na mídia e, conseqüentemente, provoca maior medo, construindo cidadãos isolados, opondo-se ao fortalecimento de uma democracia no país, a qual demanda reunião e co-presença de cidadãos nos espaços públicos(p.215).

4- A violência familiar: nesta modalidade, há especificidades a serem compreendidas, com dinâmicas diferenciadas, que demandam variadas intervenções, considerando seus diversos atores: agressores e vítimas.

5- A violência da corrupção: provoca uma vitimização coletiva e difusa. A corrupção é definida como crime no Código Penal desde 1930, entretanto, historicamente, não tem gerado punição ( p.215).

6- A violência do preconceito e da discriminação: extremamente grave e base de muitos crimes. 
7- A violência das Instituições: considera aquelas que lidam diretamente com a prevenção, repressão e recuperação de crimes e criminosos, como a polícia e o sistema prisional, e ainda aquelas que, "através das regras de coexistência oprimem a individualidade em níveis muitas vezes insuportáveis como, por exemplo, as instituições escolares, que dialogam com uma violência externa, e que ao mesmo tempo produz esse fenômeno no seu interior" (p.217).

A compreensão da violência em suas múltiplas esferas e dimensões, não permite adotar respostas únicas e simplistas para os problemas gerados por ela. Sendo assim, indivíduos isolados, ação única da polícia, projetos sociais, pontuais, ação educacional sistemática não podem dar conta da multidimensionalidade do objeto da violência. Para enfrentamento dos problemas da violência, as soluções apontam para criação de interlocuções múltiplas, redes de trabalho, alianças e ações cuidadosamente voltadas à reparação. Ressalta-se "a necessidade de fomentar uma diversificação de interlocutores sociais, sobretudo na forma de grupos de discussão e organizações destinadas a garantir a preservação dos direitos humanos e o desenvolvimento da cidadania"(SCHILLING, 2004, p. 221).

Ainda, conforme a autora "há um contexto de vitimização coletiva na vida urbana que somente pode ser enfrentado mediante a articulação de redes de solidariedade e uma postura de 'assumir responsabilidade' (governo, com suas ações de políticas integradas, sociedade civil e indivíduos) e não por uma ingênua (e inócua) polarização de responsabilidades" (p.223).

A partir dessas reflexões, e por entendermos a violência como um fenômeno de conceituação complexa, polissêmica e controversa, assume-se, nesta investigação, o conceito de violência com base na noção de sujeito e, para efeitos operacionais, adotamos a definição de MINAYO (1999)

ela é representada por ações humanas realizadas por indivíduos, grupos, classes, nações, numa dinâmica de relações, ocasionando danos físicos, emocionais, morais e espirituais a outrem. Na verdade entende-se, aqui, que não há um fato denominado violência, e sim violências, como expressão de exacerbação de conflitos sociais, cujas especificidades necessitam ser conhecidas. Tem profundos enraizamentos nas estruturas sociais, econômicas e políticas, e também nas consciências individuais, numa relação dinâmica entre condições dadas e subjetividade (p.14). 


\subsection{FATORES E CONDIÇÕES QUE EXPLICAM A VIOLÊNCIA RELACIONADA À JUVENTUDE NO BRASIL}

Segundo MINAYO, há vários fatores que confluem e constituem o ambiente para o surgimento dos eventos fatais.A juventude é a fase da vida em que se tornam evidentes as ambigüidades e as contradições. É também a fase em que se está mais predisposto a questionar a realidade e experimentar mudanças. $\mathrm{Na}$ contemporaneidade os jovens vivenciam uma constante tensão entre a busca de sua emancipação pessoal e a subordinação aos ditames da sociedade, bem como das imagens da juventude veiculadas na mídia. A mídia exerce um papel fundamental na atribuição de sentidos e na formação da opinião pública desta geração. As imagens produzidas e reproduzidas nos veículos da mídia incorporam-se na percepção que os jovens configuram de si próprios e do mundo. Sendo assim, estimulados pela mídia, assimilam muitas das aspirações de consumo e estilos de vida; no entanto, as limitações econômicas e as condições sociais impedem que os jovens atendam a seus apelos (MINAYO, 2003).

Conforme a autora, esses são alguns elementos que podem explicar os crescentes riscos de envolvimento com o narcotráfico e outras modalidades de delinquiência. Contando com poucos instrumentos de mediação de informação e cultura em seu entorno, sendo restritas as oportunidades profissionais e a premente necessidade de compor o orçamento familiar, a juventude torna-se um grupo vulnerável à ação de criminosos, sobretudo traficantes.

A violência quando "alicia os pobres, sobretudo os jovens urbanos e das periferias, tornando-se para ele um mercado de trabalho, uma forma de ter dinheiro, bens de consumo e poder (violência infrapolítica), transforma-os na ponta de lança de negócios escusos, para cuja consecução os métodos usados são profundamente autoritários e reprodutores da exclusão social” (MINAYO, 2003, p.14).

Segundo a autora, o crescimento exorbitante (115\%) das taxas de homicídio corresponde a mais de 40 mil mortes por ano, constituindo um sinal da infraestrutura política paralela, que se exerce concomitantemente às propostas políticas oficiais dos diferentes governos. 
Embora não se tenha uma estimativa precisa sobre o custo da violência, calcula-se que são gastos, anualmente, bilhões de dólares americanos com assistência à saúde no mundo todo e, no caso das economias nacionais, mais alguns bilhões em termos de dias de trabalho perdidos, aplicação das leis e perdas em investimentos (OMS, 2002). Na realidade, muito deste custo é invisível, já que não se pode calcular o custo humano em sofrimento e dor.

Segundo o estudo do INSTITUTO CIDADANIA (2004):

a inserção da juventude na marginalidade traz, ainda um reforço considerável à cultura da intolerância e violência, uma vez que a impulsividade e a espontaneidade própria da juventude se misturam ao sentimento de poder e onipotência, ocasionado pelo porte de arma de fogo, contribuindo para a proliferação de situações marcadas pela intransigência, onde a própria juventude se converte em grande vítima" ( p.13).

A produção acadêmica atual revela a preocupação com o tema, mais de $90 \%$ de toda a produção científica sobre a violência se concentra no período a partir da década de 80 do século XX.

Pensar as relações entre violência e a situação da criança e do adolescente sob o prisma da saúde pública é uma tarefa desafiante e complexa. Muitas facetas compõem o tema e vários são os caminhos que poderiam ser trilhados como demonstram os estudos de:;MINAYO, 1990, 1999, 2002, 2003; ADORNO, 1991, 1993; MELLO, 1999, LEVISKY, 1998; 2001;.PERALVA, 2000; WESTPHAL, 2002; GALVÃO, 2002; ABRAMOVAY e RUA, 2002; SPÓSITO, 2003; ASSIS e CONSTANTINO, 2003 SCHILLING, 2004;DESLANDES, 2004; SOUZA, 2004, 2005).

ASSIS e CONSTANTINO (2003), referindo-se ao primeiro levantamento bibliográfico sobre violência no país relativo à década de 1980, e MINAYO (1990) relatam que o tema do "menor institucionalizado" ocupava o centro das atenções na década de 1970. Na década de 1980, as temáticas referentes à violência tornaram-se mais variadas, devido ao agravamento da crise urbana e à importante multiplicação do debate sobre a situação da infância brasileira. Como produto decorrente da política pública originada deste último movimento, destaca-se a implementação do Estatuto da Criança e do Adolescente (ECA, 1990). 
Segundo as autoras, o assunto mais abordado nos estudos realizados na década de 1980, especialmente por textos de cunho sociológico, foi a "delinqüência juvenil" e seus sinônimos "marginalidade", "criminalidade", "pequenos bandidos", "infração e menor". O segundo tema mais presente foi os dos "meninos de rua" e as estratégias para sua institucionalização, configurando um quadro de "infância desvalida". Na área da saúde, houve a predominância de estudos, realizados por clínicos e epidemiologistas, sobre suicídios (especialmente na psiquiatria) e os das mortes e acidentes decorrentes da violência. Despontaram na época, no final da década, documentos sobre maus-tratos, especialmente elaborados por pediatras e psicólogos. "Esses últimos trouxeram a abordagem histórica, o diagnóstico e a descrição dos casos. Buscava-se nesse momento inicial, desconstruir a noção de família ideal e protetora, mostrando-a como possível agente da violência" (ASSIS e CONSTANTINO, 2003, p.164).

Portanto, ao analisar as obras dedicadas à vasta e complexa problemática da violência, verifica-se que elas enfocam seu objeto por ângulos distintos:

\begin{abstract}
...ora privilegiando a reflexão teórico-conceitual; ora focalizando aspectos metodológicos, segundo perspectivas qualitativas ou quantitativas; ora circunscrevendo-o historicamente e elaborando-o por um prisma naturalista, biológico; ora abordando-o sob a ótica psicológica; ora circunscrevendo-o à disciplina do direito; ora tratando-o segundo viés filosófico; ora dedicando-se a descrever, classificar e comparar os seus efeitos; ora concebendo, propondo ou relatando experiências de políticas públicas destinadas a controlar sua incidência. Raras, raríssimas são aquelas que compreendem a multidimensionalidade do objeto, em um único movimento hermenêutico - cognitivo de apreensão, amparado simultaneamente na densidade de estudos especializados e na ousadia transversal de pesquisas transdisciplinares" (Soares, 2003, p. 9).
\end{abstract}

Na revisão bibliográfica realizada, verificou-se uma lacuna, indicando uma demanda de estudos que considerem o jovem cidadão na sua totalidade, com suas necessidades individuais e coletivas, a serem atendidas em um determinado território. O território entendido como uma produção social, em que os problemas reais vivenciados e as potencialidades locais, têm uma causalidade múltipla, engendrada na complexidade das relações entre os indivíduos, grupos e o ambiente social/natural. Dessa forma, para superar problemas como o da violência, os setores governamentais e não-governamentais, as instituições e as entidades precisam articular saberes e experiências no planejamento, realização e avaliação de ações, 
com o objetivo de alcançar resultados integrados nessas situações complexas, visando a um efeito sinérgico no desenvolvimento local (INOJOSA; JUNQUEIRA, 2000).

\subsection{VIOLÊNCIA, JUVENTUDE E POLÍTICAS PÚBLICAS}

Considerando que a área da saúde tradicionalmente tem concentrado seus esforços "em atender os efeitos da violência, ultimamente, ainda que de forma localizada e como iniciativas voluntárias, ou seja, ainda não institucionalizadas. Começa haver uma abordagem mais integral, incluindo aspectos psicossociais tanto do impacto sobre as vítimas como nos fatores ambientais de caracterização dos agressores" (MINAYO 2002, p.11).

A autora, referindo-se ao estudo efetuado por CRUZ NETO e MOREIRA (1999), aponta que o enfrentamento da violência contra crianças requer medidas que se contraponham a interesses econômicos, políticos e hábitos culturais profundos. Esses interesses segundo os autores, contribuem para a precária qualidade das estatísticas, especialmente as de morbidade, o que não possibilita à sociedade conhecer suas próprias fragilidades, a insustentável desigualdade social geradora de inúmeras formas de violência "e o descaso com que a sociedade e o Estado repudiam as crianças abandonadas, condenando-as a viver em 'prisões' sem qualquer projeto positivo de construção da vida" (p.112).

A autora argumenta que a violência contra jovens e crianças, de um lado, deve capitalizar toda a experiência da saúde pública na tentativa de erradicar as doenças, por outro lado não pode seguir exatamente o mesmo modelo de atuação. "A complexidade real da experiência do fenômeno da violência exige a ultrapassagem de significações e a abertura para integrar os esforços de várias disciplinas, setores, organizações e comunidade" (p.112).

A Organização Mundial da Saúde reconhece a complexidade do problema da violência e recomenda a busca de parcerias com outros setores e com a sociedade civil organizada. A saúde precisa ir além das etapas de diagnóstico, tratamento das vítimas e formação dos profissionais, enfoques hoje predominantes. (MINAYO, 2005). O enfrentamento dos problemas de violência não é tarefa exclusiva da Saúde Pública. São tarefas transdisciplinares, interinstitucionais, intersetoriais, 
transnacionais e multifocais e, cada um no seu âmbito, tem muito a contribuir (AGUDELO, 1997).

A Política Nacional de Redução da Morbimortalidade por Acidentes e Violências, através da Portaria MS/GM 737 de 16/5/2001, estabeleceu como principal objetivo contribuir para a redução da morbimortalidade por acidentes e violências no país. A Política prevê a redução da morbimortalidade, mediante o desenvolvimento de um conjunto de ações articuladas e sistematizadas de modo a promover a qualidade de vida da população. Essa política definiu propósitos e diretrizes orientadoras para a implementação de planos nacionais, regionais e locais, com base em prioridades apontadas por indicadores epidemiológicos disponíveis. Parte dos princípios de que a saúde constitui um direito humano fundamental e essencial para o desenvolvimento social e econômico, de que o direito e o respeito à vida configuram valores éticos da cultura e da saúde, e de que a promoção da saúde deve embasar todos os planos, programas, projetos e atividades de redução da violência e dos acidentes.

O desafio de formular, implementar e monitorar os planos nacionais, regionais e locais, coloca a necessidade de considerar os princípios e pressupostos que levem em conta a magnitude, singularidades e complexidades das dinâmicas e processos das diversas expressões da violência. A violência é reconhecida como uma questão complexa, cuja abordagem requer a mobilização de ampla rede de apoio social, interinstitucional e intersetorial.

As dificuldades sentidas por jovens e adolescentes, independentemente do lugar em que vivem e do grupo social a que pertencem, estão relacionadas com as transformações profundas e ameaças de desintegração de um processo civilizatório, cujas bases estiveram voltadas para garantir, ao ser humano, condições de segurança contra os perigos à sua trajetória existencial. Eles serão parte de uma sociedade que valoriza cada vez mais saídas individuais (SCHOR,1999).

Segundo SCHOR, para superar os problemas, é fundamental o exercício da cidadania plena e a garantia de respeito dos direitos. Segundo SCHOR, "A participação social é um fator fundamental para o reordenamento das relações de poder e uma nova articulação entre os atores sociais. É pela participação que o jovem 
irá integrar-se nos processos coletivos, aumentar sua auto-estima e tornar-se sujeito de sua própria história" (SCHOR,1999, p. 55).

O Estado, na condição de coordenador das políticas para a juventude no nosso país, precisa propor medidas que dêem conta do problema da juventude e violência em sua complexidade. Nesse sentido, manifesta-se o Instituto de Cidadania: "uma política de juventude em nosso país, de alcance estratégico, deve assumir e praticar a integração e a transversalidade, exigindo um novo "amálgama" de sentidos, enfoque geracional e meios apropriados de validação, gestão e avaliação. Deve, ainda, criar mecanismos de proteção social, expedientes que gerem novas oportunidades de inserção profissional e sócio-cultural e incentivem a participação dos jovens"(INSTITUTO CIDADANIA, 2004, p. 21,).

Ao se pensar na necessidade de identificar estratégias para a prevenção da violência, verifica-se que estudos como o de SPÓSITO e CARRANO (2003) mostram que, na sociedade brasileira, há um consenso inicial em torno da necessidade de implementação de políticas públicas destinadas à juventude. Ao examinarem as ações federais, observadas no período de 1995-2002, e alguns caminhos percorridos no âmbito dos municípios, em direção à constituição dessas políticas, os autores destacam que "é preciso considerar que o país convive com mudanças expressas nas políticas de juventude que nascem de iniciativas municipais diversificadas e que poderão confluir para a construção de um novo paradigma em torno da questão" (p.1).

Ressaltam ainda que há alguns desafios importantes, de difícil equacionamento para o governo federal:

não só precisa contribuir efetivamente para a construção de um modo diverso de compreensão dos jovens na sociedade brasileira a ser expresso tanto sob a forma de políticas públicas democráticas que reconheçam ou não o cumprimento dos direitos institucionais historicamente negados - educação, saúde e trabalho - como capazes de se abrirem para outras modalidades de ação que contemplem novos direitos de juventude (SPÓSITO e CARRANO, 2003, p.31)

Segundo os autores, o desafio maior é "inscrever as políticas de juventude em uma pauta ampliada de direitos públicos de caráter universalista. Essas orientações devem pressupor os jovens como sujeitos dotados de autonomia e 
interlocutores ativos na formulação, execução e avaliação das políticas a eles destinadas" (SPÓSITO e CARRANO, 2003, p. 32).

De acordo com NOVAES (2003), embora no Brasil a Constituição de 1988 e, sobretudo, o Estatuto da Criança e do Adolescente constituam importantes parâmetros para elaboração de políticas públicas, há um vazio muito grande neste campo em termos de políticas públicas para a juventude brasileira. Hoje falar em políticas públicas para a juventude é também falar em segurança pública e direitos humanos. "Segurança pública é requisito essencial para a inclusão social" (NOVAES, 2003, p.140). E mais ainda é adotar estratégias, produzir dados empíricos, que possibilitem chamar atenção dos que tomam decisões, especialmente os que detêm o poder econômico, para a complexidade e multicausalidade da questão -juventude e violência -, para que as ações e os investimentos em práticas públicas possam ser transversais e integrados, ampliando os espaços de ação, de participação e a visão da responsabilidade social (LEVISKY, 2001, p.14).

Considerando a saúde "um direito social", e o Estado, o primeiro responsável em garanti-la, o campo saúde passa a ser visto também como um espaço de cidadania. CAMPOS (1991) afirma que é necessário pensar em novas formas de cidadania, que enfatizem aspectos coletivos, critérios e formas de participação e melhor equilíbrio entre subjetividade e cidadania como identidade e exercício político. Nessa ótica, o objeto da Saúde Pública se amplia na direção do cuidado e da defesa da vida e do bem-estar coletivo, ocorrendo uma participação ativa e decisória.

Os fatores que contribuem para respostas violentas, sejam eles relacionados a condições sociais, econômicas, políticas e culturais, podem ser mudados. Experiências bem-sucedidas em todo o mundo, desde trabalhos individuais comunitários em pequena escala até políticas nacionais e legislativas, têm sido avaliadas e os resultados difundidos (OMS, 2002). Hoje a Promoção da Saúde, e neste caso a Promoção da Paz e não-Violência, aparece como estratégia de produção social da saúde no cotidiano dos indivíduos, grupos e comunidades, na relação com o micro-ambiente de vida e o macro-ambiente estrutural. 


\section{A NOÇÃO DE TERRITÓRIO}

Considerando que no nível local ocorre o contato direto entre indivíduos, famílias e grupos sociais e geram-se a comunicação e as oportunidades de educação e promoção da saúde, definir o entendimento que temos sobre território torna-se necessário para o desenvolvimento deste estudo. No senso comum, território é o espaço físico, o ambiente em que vivemos e é externo à vida da sociedade. Pode ser pensado também como um espaço social a partir do qual a vida, em toda a sua potencialidade, desenvolve-se. De acordo com SACARDO \& GONÇALVES (2007):

o território, como realidade complexa, constitui um espaço vivo em permanente construção, pois, para além das condições objetivas que oferece, ou não, para os que nele habitam, como redes de serviços públicos e de serviços privados, redes comunitárias, oferta de trabalho e renda, equipamentos de lazer e cultura, apresenta também condições subjetivas, que decorrem das relações estabelecidas pelos sujeitos com seu território, manifestas em desejos, sonhos, sofrimentos e nas redes de sociabilidade construídas (p. 113-114).

A adoção dessa formulação orientou o pensamento sobre o território como produção social, tendo como pré-requisito a participação social na produção de um projeto, reconhecendo a rede informal de troca de saberes e o processo de coletivização. Aceitando a dimensão subjetiva, demos lugar à vida, ao conhecer e reconhecer a história que decorre da interação e tensão entre sujeitos individuais e coletivos, e explica o cotidiano, o universo cultural da população que vive no território, enfim, sua subjetividade. O território, visto dessa forma, "diz respeito não somente aos aspectos objetivos da realidade vivida pelas populações, mais envolve igualmente sua dimensão subjetiva, que aparece na forma concreta através das manifestações de sofrimentos, desejos e expectativas (...)." (KOGA, 2003, p. 39). Nessa perspectiva, entende-se toda a gama de relações estabelecidas entre os moradores, que de fato o constroem e reconstroem permanentemente, em função da diversidade de interesses, disputas, conflitos e, ao mesmo tempo, pela possibilidade de inovação, criatividade, parcerias e ações coletivas.

Conforme CASTELLS e BORJA (1996) e MENDES e DONATO (2003), ainda neste enfoque, o território constitui-se como "ator", e não apenas como "palco", o que significa entendê-lo no seu papel ativo, ou seja, como um espaço que 
dinamiza as relações, integra culturalmente e se converte em um lugar de respostas possíveis a problemas e propostas necessárias a cada momento.

No contexto da promoção da saúde, um dos referenciais teóricos no qual está apoiada esta tese, o papel potencializador dos estudos territoriais e da vertente do território pode dar início a uma nova trama para tecer políticas públicas brasileiras em direção à justiça social.

As interfaces do território denotam sua complexidade e também sua riqueza para o campo das políticas públicas, acrescentando outros parâmetros que ultrapassam a segmentação de demandas ou focalizações de ações. A dimensão territorial permite uma perspectiva de totalidade da questão social, indo além dos aspectos das necessidades, contrapondo-se à noção simplista de necessitados ou carentes referidas comumente nas políticas públicas direcionadas aos pobres, que os destitui da condição de sujeitos (KOGA, 2003).

O território é antes de tudo um espaço político, em sentido amplo, capaz de produzir um desenvolvimento autocentrado. Nesse prisma, o território agrega todos aqueles que querem compartilhar, exprimem o desejo de trabalhar juntos, reunindo todos que querem continuar senhores de seu futuro.

No lugar em que se desenvolve a trama das relações sociais de cada indivíduo e ocorre o processo de identificação. O significado de cada lugar é dado pelo seu uso: de produzir ou de consumir; de adoecer, de curar; de amar; de lutar (CARVALHO, 2001).

Nessa visão, os lugares são concebidos como espaços concretos, sínteses de múltiplas determinações, campos privilegiados de ação, que possibilitam a implementação de iniciativas inovadoras, com a inclusão de diversos atores locais no estabelecimento de políticas. A apropriação dos sujeitos do território implica um processo de identificação com os diferentes lugares e suas particularidades históricas e políticas, facilitando assim uma participação mais efetiva. O território torna-se, portanto, um espaço de aprendizado e de conquista da cidadania, constituindo o lugar da promoção da solidariedade, onde vários sujeitos sociais atuam coletivamente buscando melhorar as condições de vida e saúde.

Segundo CARA (1996), a territorialidade refere-se à qualidade subjetiva do grupo social ou do indivíduo que lhe permite, com base em imagens e representações 
e projetos, tomar consciência de seu espaço de vida. É traduzida no sentimento de pertencimento, ou seja, o sentimento de "ser"e/ou "estar", em um determinado lugar no qual se reconhece como pessoa, onde é influenciado e ao mesmo tempo influencia a dinâmica deste lugar, possibilitando o desenvolvimento do território.

SANTOS (1987) dá uma contribuição importante ao refletir sobre o peso do "lugar", do território, sobretudo, o intra-urbano. Segundo o autor, a possibilidade de ser "mais ou menos cidadão" depende em grande proporção do ponto do território onde nos encontramos. O componente territorial implica, ainda, que seus habitantes tenham acesso aos bens e serviços indispensáveis, e também que haja uma adequada gestão deles, assegurando benefícios à coletividade.

No território, na base da sociedade civil, na extrema eqüidade ou iniqüidade social, constroem-se as experiências coletivas e os sujeitos. É preciso pensar a sociedade civil construindo-se como espaço público, a partir do local, com a sua diversidade e com a idéia de direito, de igualdade indo além do elemento político. $\mathrm{O}$ espaço público deve criar a esfera pública a partir da diversidade e da conflitividade. É na esfera pública atravessada pela diversidade, partindo das micro-esferas públicas, na base do território, na relação de vida, ou seja, da casa e fora desta, que se pode aprender e construir uma ação de pertencimento. 


\section{PARTICIPAÇÃO SOCIAL}

A Carta de Otawa (1986) preconiza que a promoção da saúde começa com a participação efetiva e concreta da comunidade na eleição de prioridades, na tomada de decisões e na elaboração e desenvolvimento de estratégias para alcançar melhor nível de saúde.

A promoção da saúde consiste em um processo de capacitação da população para identificar os problemas de saúde e suas causas, a fim de que se definam os meios necessários para melhorar e exercer maior controle sobre a saúde, tendo como objetivo central que os indivíduos e setores sociais aumentem o controle sobre os determinantes do processo saúde - doença, ou seja, fortaleçam-se na luta para a melhoria das suas condições de vida (M S, 2004).

O termo participação possui inúmeras conceituações na medida em que for considerado um meio ou fim (COMARÚ, 2004). Participação é uma conquista, um processo, no sentido legítimo do termo: infindável, em constante vir-a-ser-sempre se fazendo. É, em essência, autopromoção e existe enquanto conquista processual, não pode ser entendida como dádiva, nem como concessão. Em decorrência do processo de participação, podem ocorrer mudanças nas relações de poder (DEMO, 1988). A participação não é ausência, superação, eliminação do poder, "mas outra forma de poder" para intervenção na realidade (DEMO, 1988).

A participação, conforme JACOBI (2004), surge no quadro da transição pósdemocrática no Brasil, originada pela força das pressões da sociedade civil mais ativa e organizada, com novos espaços públicos de interação, e especialmente de negociação. "A participação social emerge como referencial de rupturas e tensões, e as práticas participativas associadas a uma mudança qualitativa da gestão assumem visibilidade pública e repercutem na sociedade" (JACOBI, 2004, p. 275). Conforme o autor, as transformações político-institucionais assim como a ampliação dos canais de representatividade dos diversos setores para atuar junto aos órgãos públicos "mostram o potencial de constituição de sujeitos sociais identificados por objetivos comuns para transformar a coisa pública, configurando a construção de uma nova institucionalidade" (JACOBI, 2004, p. 275). 
O surgimento das políticas públicas pautadas pelo componente participativo, conforme JACOBI (2004), “está relacionado com as mudanças na matriz sociopolítica por meio de um maior questionamento do Estado como principal agente indutor de políticas sociais. A noção de participação é concebida principalmente pela ótica dos grupos interessados e não apenas pela perspectiva dos interesses globais definidos pelo Estado" (JACOBI, 2004, p. 275). Segundo JACOBI (2004), o desafio imposto "é construir uma ordem societária baseada na articulação da democracia política com a participação social, representada por uma maior permeabilidade da gestão das demandas dos diversos sujeitos sociais e políticos” (JACOBI, 2004, p.275). Dessa forma, surge então "a possibilidade de busca de uma conexão entre a implantação de práticas descentralizadoras e uma engenharia institucional que concilie participação com heterogeneidade, formas mais ativas de representatividade. A participação social enquadra-se no processo de redefiniçãa do público e do privado dentro da perspectiva de redistribuir o poder em favor dos sujeitos sociais que geralmente não têm acesso" (JACOBI, 2004, p.275).

A participação, no campo interpretativo, é analisada sobre dois enfoques segundo JACOB, (2004), apoiado em CUNILL (1991).No primeiro, está associada à democratização e tem como referência o fortalecimento dos espaços de socialização, descentralização do poder e crescente autonomia das decisões. Este enfoque enfatiza o papel mais independente dos sujeitos sociais. O segundo enfoque aborda a participação como ações organizadas para criação de espaços e formas de articulação do Estado com os sujeitos sociais. Configura-se como um instrumento de socialização política, que reforça o papel da participação nesses espaços como meio para realizar interesses e direitos sociais que demandam uma atuação pública (JACOBI, 2004).

Assim, a participação social pode aglutinar diferentes setores e instituições da sociedade civil para originar políticas públicas capazes de produzir saúde. A implementação da idéia de políticas públicas saudáveis tem como premissa a participação social envolvendo entidades não-governamentais, sindicatos, associações de moradores e de bairros, membros de comunidades, cidadãos comuns. Sendo as políticas públicas exclusivas do aparelho estatal, devem ser elaboradas e pactuadas em fóruns participativos, sujeitas a negociações e a lutas políticas em 
diversas arenas e cenários, representando uma redistribuição de direitos, responsabilidade e poder entre Estado e sociedade civil (WESTPHAL et al. 2000, LABONTE, 1996).

\section{A EXPERIÊNCIA SOCIAL E A AÇÃO}

O interesse desta pesquisa em estudar os jovens em termos da sociologia da ação provém do fato de que na nossa realidade há poucos estudos que focalizam o processo e os resultados da transformação dos jovens em sujeitos, na dinâmica social da vida que inclui as ações coletivas que ocorrem nos territórios onde vivem. Apoiados inicialmente em MELUCCI (2001, p.100), procuramos olhar para a questão "juventude/violência" e, a partir dessas premissas, começamos a nos interrogar sobre a condição juvenil. Para autor acima mencionado, a interrogação implícita nas diversas pesquisas sobre a condição juvenil, nesta perspectiva, é saber se os jovens são sujeitos potenciais de ação coletiva, buscando uma compreensão mais aprofundada da condição e da cultura juvenil nas sociedades, sejam elas dos países do Norte ou do Sul.

Abordar a juventude no cotidiano é outra forma de compreender os jovens como sujeitos de direitos no mundo globalizado. A globalização, segundo BAUMAN (1999), está na ordem do dia, transformando-se em um lema, um encantamento mágico, "capaz de abrir as portas de todos os mistérios presentes e futuros". A globalização "é o destino irremediável do mundo, um processo irreversível; e também um processo que nos afeta a todos na mesma medida e da mesma maneira" (BAUMAN,1999, p. 7).

A compreensão tempo/espaço encerra a multifacetada transformação em curso dos parâmetros da condição humana. A análise das causas e consequiências sociais mostra que os processos globalizadores, não têm a unidade de efeitos que se supõe. "Os usos do tempo e do espaço são acentuadamente diferenciados e diferenciadores. A globalização tanto divide como une; divide enquanto une - e as causas da divisão são idênticas às que promovem a uniformidade do globo" (BAUMAN,1999, p.8). Os jovens de todo o mundo estão vivendo essa transformação e se transformando com ela. 
De acordo com BAUMAN (1999), no mundo globalizado, o jovem, como ser local, fica sujeito à privação e degradação social. Os desconfortos da existência localizada compõem-se do fato de que, com os espaços públicos removidos para além do alcance da vida localizada, as localidades estão perdendo a capacidade de gerar e negociar sentidos, tornando-se cada vez mais dependentes de ações que dão e interpretam sentidos e não conseguem controlá-las (BAUMAN,1999, p.8).

As pesquisas têm mostrado que os territórios urbanos hoje, para o jovem, tornaram-se campos de batalha de uma contínua guerra espacial. Irrompem-se, às vezes, nos espetáculos públicos, motins internos, conflitos com a polícia e outras lutas travadas diariamente. É no cotidiano desses jovens que tudo acontece. Segundo MELUCCI (2001), é na experiência cotidiana, que procuram compreender as discrepâncias entre o agir e as palavras que utilizam para descrever suas ações e entender por que se sentem pessoas distintas, nos diferentes âmbitos de suas vida. De acordo com o autor, "é no espaço de vida local que ocorrem os processos sociais, produtos de ações, escolhas e decisões é onde se dá o agir coletivo e onde a mobilização coletiva assume formas organizativas diferentes da tradição política"(MELUCCI, 2001, p. 95).

Para MELUCCI (2001), “a ação não se deduz pela condição juvenil”, ao contrário, é necessário identificar no nível do sistema os problemas que estão no centro dos conflitos sociais, os campos sobre os quais se jogam o confronto de recursos decisivos. Com base na sociologia da ação, procuramos entender quais elementos da condição juvenil são suscetíveis de ativar, em certas condições conjunturais, o desenvolvimento do jovem como sujeito, no contexto das ações coletivas, transformando este grupo em um ator de conflito, para oferecer subsídios para as políticas e ações destinadas a promover o crescimento e o desenvolvimento normal do jovem que vive nas regiões periféricas das grandes metrópoles.

Neste sentido procuramos, entre os teóricos que trabalham nesta linha, um autor pesquisador em que pudéssemos encontrar referências que colaborassem na interpretação dos dados obtidos, assim, as lógicas de ação de DUBET foram as escolhidas para isso.

Para DUBET (1994), a vasta produção sociológica francesa contemporânea tem uma característica comum: definem-se como uma teoria da ação. Cada autor, 
entretanto, interpreta o seu objeto de interesse a partir de uma imagem, de uma definição da atividade dos atores, de uma antropologia ou de uma representação das relações dos atores com o sistema (DUBET, 1994, p. 79). Todos esses paradigmas da ação também têm um ponto em comum: eles recusam de maneira mais ou menos clara os princípios da sociologia clássica, ou seja, "a morte do sujeito e a recusa da própria idéia do ator mediante a exata sobreposição do ator e do sistema" (DUBET, 1994, p. 79).

Para o autor, o tema central é, portanto, o esgotamento da idéia clássica de sociedade. Segundo DUBET: "se a 'sociedade' deixou de ser uma representação adequada, se já não é identificável com um sistema, se já não tem centro e unidade, então é preciso pensar que a dispersão de lógicas de ação passa a ser a regra. A multiplicidade dos paradigmas de ação resulta desta mutação, convidando 'empiricamente' que se oponha a noção de experiência social à concepção de ação da sociologia clássica" (DUBET, 1994, p. 91).

Segundo DUBET (1994), a concepção de experiência social aparece como possibilidade explicativa no momento em que a representação clássica da 'sociedade' já não é adequada e no caso em que os atores são obrigados a gerir simultaneamente várias lógicas da ação que remetem a várias lógicas do sistema social. O entendimento atual de sistema social, em sua complexidade, ultrapassa os limites de um sistema, passando a considerar a existência e a co-presença de sistemas estruturados por princípios autônomos (p. 94).

A experiência social é definida pela combinação de várias lógicas de ação. As combinações e lógicas de ação que organizam a experiência não têm centro, isto é, elas não se assentam sobre qualquer lógica única ou fundamental (DUBET, 1994, p. 94).

Na medida em que a unidade da experiência social não é dada, ela vai gerar uma atividade dos indivíduos, uma capacidade crítica e uma distância em relação a eles mesmos. Para DUBET (1994) é essa distância em relação a si que torna o ator um sujeito socialmente construído na heterogeneidade das lógicas e das racionalidades da ação.

A experiência social ainda,conforme o autor "não é uma esponja, uma maneira de incorporar o mundo por meio de emoções e das sensações, mas uma 
maneira de construir o mundo, na subjetividade. É uma atividade que estrutura o caráter fluido de vida" (, p. 95).

A sociologia da experiência, portanto, define a experiência como "uma combinação de lógicas de ação, lógicas que ligam o ator a cada uma das dimensões do sistema. $\mathrm{O}$ ator é obrigado a articular lógicas diferentes, e é esta dinâmica gerada por esta atividade que constitui a subjetividade do ator e a sua reflexividade" (DUBET, 1994, p. 107).

A noção de experiência só tem sentido e utilidade se a ação não for redutível à versão subjetiva do sistema e se o ator não estiver totalmente socializado. A parte não socializada da ação continua sendo socialmente definida e construída e o ator não está totalmente socializado porque a ação não é redutível a um programa único.

Existe na experiência social alguma coisa de inacabado e de opaco, porque não há adequação absoluta da subjetividade do ator e da objetividade do sistema .A socialização não é total, não porque o indivíduo escape ao social, mas porque a sua experiência se inscreve em registros múltiplos e não congruentes. É nisso que assenta aquilo que se poderá considerar com a autonomia do indivíduo (DUBET, 1994, p. 98).

O objeto da sociologia da experiência social é a subjetividade dos atores e a consciência que eles têm do mundo e deles próprios.

Numa perspectiva sociológica "a subjetividade é entendida como uma atividade social gerada pela perda da adesão à ordem do mundo, logos” (DUBET, 1994, p. 101). A experiência individual, ao mesmo tempo que se torna mais subjetiva, torna-se mais social. "Ela é, então, mais 'manipulada', mais controlada, mais aberta aos olhos dos outros. Mas, simultaneamente, esta experiência só pode ser legítima aos olhos dos atores na medida em que ela continue a ser uma experiência autêntica, vivida como a expressão de uma personalidade" (DUBET, 1994, p.103).

A subjetividade dos atores não é uma imagem vaga do vivido, evocando o tema da consciência como reflexo e fluxo ininterrupto de sentimentos que se presume exprimirem uma personalidade autêntica refreada pela sociedade. Pelo contrário, "há de se levar a sério o sentimento de liberdade manifestado pelos indivíduos, não porque ele seja a expressão de 'uma verdadeira liberdade', mas porque é testemunha da própria experiência, da necessidade de gerir várias lógicas, da percepção da ação da experiência” (DUBET, 1994, p.101). 
É na experiência que poderão ser lidos os problemas sociais.

Ao contrário da imagem heróica de um sentimento de liberdade conquistadora, os atores sentem antes esta liberdade em forma de angústia, de incapacidade de escolhe, de inquietação quanto às conseqüências das opções. De modo geral, os atores vivem mais naturalmente a sua atividade na dor que na felicidade, e o desejo de ser autor da sua própria vida é mais um projeto ético que uma realização (DUBET,1994, p.101).

A experiência social não é um fluxo de sentimentos e de emoções, ela não é a expressão de um ser ou de um sujeito, ela é socialmente construída. Dessa forma, o que se conhece da experiência é aquilo que é dito pelos atores. É no discurso dos atores que se obtêm as categorias sociais da experiência.

Sendo assim, ela solicita um código cognitivo para designar as coisas, os sentimentos, os objetos identificados no patrimônio cultural disponível. Mesmo que a experiência pretenda ser puramente individual, ela só existe na medida em que é reconhecida e, eventualmente, partilhada e confirmada por outros.

Os atores sentem a necessidade de explicarem suas práticas. Estão constantemente explicando o que fazem, porque o fazem e justificando-se. A experiência social é crítica, pois se constroem acordos, arranjos, por meio de uma filosofia cotidiana. Quanto mais nos afastamos da unidade do ator e do sistema, mais os universos compartilhados de referência se diversificam, e cada vez mais os indivíduos são obrigados a deliberar. "Na prática elementar de justificação, os indivíduos colocam a sua própria experiência à distância, julgam-na, apelam para normas mais ou menos latentes mobilizadas para o caso" (DUBET, 1994, p.106)

As normas têm o papel de conferir à experiência uma dimensão crítica, "porque o indivíduo não pode ajuizar acerca da sua experiência senão em relação a outros e aos debates normativos surgidos na situação" (DUBET, 1994, p. 106). É a reflexividade que faz com que os atores não vivam na adesão imediata e no testemunho puro, reconstruindo-se sempre a uma distância em relação a eles próprios. DUBET (1994) considera que o trabalho reflexivo é mais intenso quando os indivíduos se encontram em situações que não são inteiramente codificadas e previsíveis. Portanto, quanto mais nos afastamos da ação considerada como um papel, e nos voltamos para as experiências sociais e por condutas estruturadas por lógicas diversas, mais intensa é a reflexividade (p. 107) . 
DUBET (1994) afirma que nos movimentos sociais esta crítica é mais nítida, "quando os atores se apóiam na sua experiência para contestarem uma organização social ou, mais exatamente, a dominação de que ela resulta. Uma sociologia da experiência incita a que se considere cada indivíduo como um intelectual, como um ator capaz de dominar conscientemente, pelo menos em certa medida, a sua relação com o mundo" (DUBET, 1994, p.107).

A análise da experiência social está pautada por três grandes princípios: a ação social não tem unidade, é definida por relações sociais e a experiência social é uma combinatória. $\mathrm{Na}$ análise da experiência social, realizamos três operações intelectuais.

A primeira, de ordem analítica, consiste em isolar e descrever as lógicas de ação presentes em cada experiência. A experiência combina vários tipos puros de ação e há pouca probabilidade de identificá-la com um tipo puro de ação.

A segunda implica compreender a própria atividade do ator, ou seja, a forma como ele combina e articula as diversas lógicas. Embora seja possível construir intelectualmente tipos puros de ação, não pode haver tipos puros de experiência. Segundo DUBET (1994), "as experiências sociais são sempre construções históricas de 'tipos históricos', formados pela combinação de tipos puros" (DUBET, 1994, p.112).

A terceira consiste em ir da experiência para o sistema e "compreender quais são as diferentes lógicas do sistema social mediante a forma como os atores as sintetizam e as catalisam tanto no plano individual como no plano coletivo" (DUBET, 1994, p.112). Segundo DUBET (1994), mesmo considerando que o sistema social é apenas o produto da ação social, é certo que cada lógica pura da ação não pode pertencer totalmente ao ator por dois motivos: primeiro "porque é uma lógica que implica em certa coerência, uma força de racionalidade na qual nem tudo é possível no seio de cada lógica da ação. Em segundo porque ela é determinada pala natureza do sistema social para a qual ele remete; os fatos sociais podem ser atingidos por via indireta dos atores e da experiência deles" (DUBET, 1994, p.112). 


\subsection{AS LÓGICAS DE AÇÃO}

Para DUBET (1994), o enfraquecimento da idéia clássica de sociedade leva a considerar que o conjunto social, já não é estruturado por um princípio de coerência interna, sendo formado pela justaposição de três grandes sistemas:

O primeiro é o sistema de integração, chamado por muito tempo de comunidade. O segundo é o sistema de competição, um mercado ou vários mercados - a noção de mercado extravasa o mero domínio econômico. E o terceiro é o sistema cultural, "a definição de uma criatividade humana não totalmente redutível à tradição de utilidade" (DUBET, 1994, p.113). De maneira geral, uma formação social é composta por uma comunidade, por uma economia e por uma cultura. "Cada um desses elementos é sustentado por uma lógica própria e define-se num campo e num espaço particulares: geralmente, as comunidades são nacionais, locais, étnicas, o mercado é internacional, a cultura é hoje em dia dos indivíduos" (DUBET, 1994, p.113).

Para DUBET (1994) “cada experiência social resulta da articulação das 3 lógicas da ação: a integração, a estratégica e a subjetivação. Cada ator individual ou coletivo, adota necessariamente estes 3 registros da ação que definem necessariamente uma orientação visada pelo ator e uma maneira de conceber as relações com os outros" (p.113).

Na lógica da integração, “o ator define-se pelas suas pertenças, visa mantêlas e fortalecê-las no seio de uma sociedade considerada então como um sistema de integração". Na lógica estratégica, "o ator tenta realizar a concepção que tem dos seus interesses numa sociedade concebida então como um mercado." Na lógica da subjetividade, "o ator representa-se como um sujeito crítico confrontado com uma sociedade definida por um sistema de produção e de dominação" (DUBET, 1994, p.113).

Segundo o autor, estas três lógicas de ação remetem para os elementos que estavam contidos na idéia clássica de sociedade. A sociedade como Estado-nação tinha a capacidade de articular estratégias de mercado e de cultura e até mesmo de ligar as ações de integração comunitárias. Atualmente, pelo fato de esses elementos estarem sendo considerados separadamente, obriga-se a fazer um esforço para distinguir o mais nitidamente possível as lógicas da ação às quais eles correspondem. 
No entanto qualquer formação social é definida pela co-presença de uma capacidade de integração comunitária que nos opõe aos outros, de um sistema de concorrência regulada, e de uma cultura que define a capacidade crítica e a capacidade de ação voluntária" (DUBET, p. 114).

Essa tipologia de análise de ação inspira-se diretamente na obra de TOURAINE. Cada uma pode ser decomposta nos seguintes elementos analíticos: de Identidade, de Oposição e de Totalidade (I, O, T), nos quais o ator põe em jogo uma definição de si mesmo, da natureza da sua relação com o outro e daquilo que está em jogo nessa relação". Para DUBET (1994) esse jogo de princípios não está reservado apenas aos movimentos sociais, é um instrumento analítico de alcance mais amplo. Essas três lógicas da ação são consideradas autônomas pelo autor e elas não se hierarquizam no seio da sociedade, e por isso prefere falar em experiência e não em ação, como faz TOURAINE, fiel à sociologia clássica, afirmando que como lógicas de ação elas mantêm entre si relações necessárias. DUBET (1994), analisando o momento social e intelectual em que nos encontramos - depois da sociologia clássica e da representação de sociedade que lhe esteve associada -, prefere considerar que as ligações entre as lógicas de ação são aleatórias.

\subsection{COMPREENDENDO AS LÓGICAS DE AÇÃO}

- A lógica da Integração

E a lógica da sociologia clássica e corresponde ao nível de organização, isto é, aos mecanismos de integração que estão em prática em qualquer sociedade "sem serem, por isso, identificáveis com a sociedade no seu conjunto" (DUBET, 1994, p. 115).

A identidade é integradora: a identidade do ator é definida "como sendo a vertente subjetiva da integração do sistema” (DUBET, 1994, p. 115). A identidade, para DUBET, “é tão só a maneira como o ator interiorizou os valores institucionalizados por meio dos papéis. $\mathrm{O}$ indivíduo define-se e apresenta-se aos outros pela sua presença, pela sua posição, por aquilo que ele vive, ele próprio, como um ser, freqüentemente como uma herança. Neste registro da ação, a personalidade está mais perto da personagem social” (p.115). 
No decurso da socialização primária, infantil e profunda, o indivíduo incorpora as expectativas de outrem, transformando sua identidade em uma espécie de natureza quando esta se refere à língua e à nação, ao sexo, à religião, à classe social, entre outros. Segundo DUBET (1994), inúmeros elementos são dados aos indivíduos ao nascer e que passam a fazer parte dele, mais do que seja ele a trazê-los consigo. "É neste nível de ação que a noção de 'personalidade de base' pode ter uma significação, de tal modo, o indivíduo interiorizou os códigos sociais elementares cuja destruição ou contestação ele vive, de resto, como uma ameaça profunda a atingir o núcleo estável do seu ser. Deste ponto de vista a identidade é vivida como uma ascription, uma atribuição social graças à qual o ator se constitui como um ser social" (p.115).

Essa identidade é vivida profundamente como uma história, como uma base, aquém da qual só haveria barbárie ou morte. Essa identidade integradora muitas vezes fica "nas franjas da consciência".O ego do indivíduo "é apenas a representação do seu papel e da sua posição incorporada, encarnada num corpo, numa relação tão íntima consigo mesmo que só a introspecção, na medida em que é possível, ou o trabalho analítico, diz-se podem fazer com que ele emerja à consciência" (DUBET,1994, p.115).

O autor com base em MEAD (1963), argumenta que "não há Ego sem Nós". Os diversos grupos e comunidades constroem, então, ritos que fiam o EGO no NÓS que o estrutura (DUBET, 1994, p. 115). Como exemplos, o autor cita os ritos de passagem, aqueles que dão ao indivíduo um novo estatuto, que é também uma nova personalidade, um renascimento. Nas sociedades modernas, encontramos substitutos atenuados desses ritos, como os desvios tolerados, reservados à adolescência. (DUBET, 1994, p. 115).

Não há necessidade de que as relações entre ELES/NÓS sejam explicitamente hostis para se inscreverem em uma lógica de integração, "basta que elas funcionem no reconhecimento de uma diferença que mantém e fortalece a identidade integradora. Com muita freqüência, no entanto, o conflito reforça o sentimento de pertença dos indivíduos e, por conseguinte, a sua integração a sua identidade" (DUBET, 1994, p. 117). 
$\mathrm{Na}$ lógica da integração, a cultura é definida em termos de valores. Nesta orientação a representação da sociedade pelos indivíduos é de um edifício, cuja pedra angular são os valores. Quando os valores são ameaçados, a identidade dos indivíduos fica diretamente comprometida. "A cultura é, ao mesmo tempo, o suporte da identidade e de uma moral, no sentido mais banal, e até mesmo conservador do termo" (DUBET, 1994, p.118).

$\mathrm{Na}$ lógica da integração, o ator interpreta a cultura "como um conjunto de valores que garantem ao mesmo tempo a ordem e a sua identidade. É por esta razão que os valores, assim concebidos, remetem diretamente para a autoridade, quer dizer, para a potência associada a uma posição social que encarna a capacidade de manter a integração do conjunto" (DUBET, 1994, p.118).

- As condutas de crise

Segundo DUBET (1994) “cada lógica de ação possui uma face 'patológica', uma face na qual ela se revela mais claramente aos olhos do observador, em que ela rompe com a evidência das coisas". A patenteação da lógica da integração é particularmente viva na sociologia das condutas de crise (p.119). Na sociologia clássica, é identificada com os temas da anomia e desorganização social. "As condutas sociais patológicas são interpretadas como resultantes de uma falta de socialização, que por sua vez remete para uma falta de integração do sistema”. (p.118).

Para DUBET (1994) “a explicação das condutas em termos de crise e de defesa da identidade faz parte da linguagem comum da experiência social, emergindo quando as identificações integradoras são ameaçadas" (p.121).

\section{- A estratégia}

Segundo DUBET (1994), na lógica da estratégia, a identidade do ator, as relações sociais e o que nelas está em jogo são definidas de forma muito diferente. A identidade também "pode ser construída pelos atores como um recurso a partir do momento em que a sociedade já não é representada como um sistema integrado, mas como um campo concorrencial, de que o mercado seria uma figura 'pura'. Por isso, 
esta lógica não diz respeito somente ao domínio de trocas econômicas mas também ao conjunto das atividades sociais" (DUBET, 1994, p.121). A identidade é definida pelo ator, em termos de estatuto - entendido como a posição relativa de um indivíduo, ou seja, a probabilidade que ele tem de influenciar os outros graças aos meios ligados a essa posição. Ela não se distingue, no seu conteúdo, da identidade integradora, "ela é a realização dessa última, a herança e o 'ser', do ponto de vista dos recursos numa relação de concorrência" (DUBET, 1994, p.121).

Os motivos da ação integradora visam ao fortalecimento, à confirmação e ao reconhecimento da pertença, enquanto os motivos da ação estratégica são sustentados por uma racionalidade tida como limitada e que visa aos fins concorrenciais. "A estratégia implica uma racionalidade instrumental, um utilitarismo da própria ação, que visa conceder os meios para as finalidades pretendidas nas oportunidades abertas pela situação" (DUBET, 1994, p.123). Esta lógica de ação não está reduzida ao simples domínio econômico, ela não corresponde a um nível ou a um campo das práticas sociais, ela faz parte também das interações puramente sociais.

Na perspectiva da lógica estratégica, a integração do sistema é substituída pela sua regulação, pela necessidade de manter as regras do jogo para que o ele seja possível. "A civilidade e a pertença ao grupo são, já não uma norma, mas uma forma do interesse bem entendido, uma condição necessária à prossecução dos objetivos" (DUBET, 1994, p.123). A ação estratégica só é possível com o apoio de uma integração mínima. "Sem uma lógica de integração simultânea, a concorrência tornar-se-ia uma guerra" (DUBET, 1994, p.123).

Dessa forma, na lógica da estratégia, "as relações sociais são definidas em termos de concorrência, de rivalidade, mais ou menos viva, dos interesses individuais e coletivos (DUBET, 1994, p.124). A sociedade é vista como um sistema de trocas concorrenciais na competição para se obter bens raros: dinheiro, poder, prestígio, influência e reconhecimento, entre outros. O jogo é regulado, raramente é de soma nula. A linguagem do jogo ou do mercado é utilizada para descrever as relações com os outros. Na lógica da concorrência, o dinheiro, o mercado e a economia permitem que se construa uma espécie de metáfora geral das relações sociais. "Fala-se em mercado conjugal, mercado escolar, mercado político, sem se estabelecer uma 
correspondência exata com as questões econômicas, a lógica do mercado basta-se a si mesma" (DUBET, 1994, p.126). Esta metáfora vai muito além da estrita economia, ela evidencia uma natureza muito especial das relações sociais. "A especificidade da lógica estratégica jamais se descobre tanto como na tensão que a opõe à da integração, ao passo que nós vivemos em dois mundos, alternando o dom e o mercado, a camaradagem e o egoísmo, redefinindo assim, de cada vez, a natureza das nossas relações com os outros" (DUBET, 1994, p. 126).

\section{- O Poder}

$\mathrm{O}$ ator, na lógica estratégica, define subjetivamente os seus objetivos e os bens visados que o colocam em situação de concorrência com outros. A natureza dos objetivos é definida pelos indivíduos e pelos grupos como aquilo que lhes interessa e lhes é útil. A definição desses bens varia de forma quase infinita em função dos campos nos quais a ação se desenrola. Sob a influência da utilidade, os valores tornam-se ora preferências, ora ideologias. As preferências "não explicam as condutas, uma vez que as opções afirmadas desenrolam-se segundo o princípio de um optimum econômico" (DUBET, 1994, p.128). Para as ideologias, "o discurso dos valores é uma derivação que tem em vista dissimular a realidade mais profunda das paixões e dos interesses autênticos inconfessáveis" (DUBET, 1994, p.128). Admitindo que o sentido real da ação está na racionalidade limitada dos atores, os valores não seriam uma finalidade, mas um meio de ação: um recurso (DUBET, 1994, p. 128). Desse modo, as mobilizações são explicadas muito mais pelas oportunidades oferecidas à prossecução das finalidades do que pelas tensões vividas pelos atores. Assim, analisando os movimentos sociais, DUBET (1994) afirma que eles não são nem irracionais, nem espontâneos.

O empenhamento na ação coletiva é racional; ele não está em ruptura com as condutas políticas institucionais e não tem em vista, no fundo, senão a entrada no sistema político ou o estabelecimento de uma pressão suficiente sobre os que decidem. O conflito social não opõe frontalmente grupos, ele põe-nos em concorrência no acesso aos recursos políticos (,p. 128).

Para DUBET (1994), “o sucesso de um movimento depende das oportunidades estruturadas, que lhes são oferecidas, da sua capacidade de mobilizar 
recursos ou mais precisamente de utilizar as ligações comunitárias, as ideologias, por vezes os próprios adversários, como recursos",( p. 29)..

- A subjetivação

A integração e a estratégia manifestam-se como lógicas positivas da ação, como realidades, diferentemente da lógica do sujeito. Esta revela-se indiretamente na atividade crítica, supondo que o ator não é redutível nem aos seus papéis, nem aos seus interesses, quando adota um ponto de vista diferente da integração e da estratégia. "A atividade crítica, quer seja cognitiva quer seja normativa, supõe a existência de uma lógica cultural pela qual o ator se distingue das outras lógicas" (DUBET, 1994, p.130). Adotando esta posição, ele passa a vivenciar uma tensão com as outras lógicas de ação.

DUBET (1994) define a identidade do sujeito como um 'empenhamento' em modelos culturais que constroem a representação do sujeito. Citando TOURAINE, o autor afirma que o indivíduo que quer construir a sua própria vida e julgá-la apóiase na representação da criatividade humana. É introduzida uma distância entre si e a sociedade. O sujeito sempre está parcialmente fora do mundo, a sua identidade é formada pela tensão com o mundo, isto é, com a ação integradora e com a estratégia (p. 130). "Este empenhamento, numa representação cultural do sujeito, é vivido como um inacabamento, como uma paixão impossível e desejada que permite descobrir-se como autor da sua própria vida, ainda que seja na amargura ocasionada pela impossibilidade de realizar plenamente este projeto" (p. 131). A identidade subjetiva, de forma indireta, mostra-se e experimenta-se como uma carência ou como uma dificuldade para realizar a representação cultural do sujeito. A parte subjetiva da identidade é percebida tanto no desprendimento quanto no empenhamento, "porque a identificação com a definição cultural de um sujeito impede a adesão total ao Ego, ao NÓS e aos interesses. Ela provoca uma reserva que impede o indivíduo de ser totalmente o seu papel e a sua posição, de ser a sua personagem social” (p.130).

Segundo DUBET (1994), “do ponto de vista do sujeito, as relações sociais são percebidas em termos de obstáculos ao reconhecimento à expressão desta subjetivação" (DUBET, 1994, p. 133). O conflito social, aqui, não é resumido à 
defesa das identidades ou à concorrência das potências, o que nele está em jogo é o que, segundo DUBET (1994), TOURAINE denomina historicidade, definida como a capacidade de os atores dirigentes se identificarem com a criatividade social (DUBET, 1994, p.133). Uma ilustração simples dessa realidade, segundo DUBET (1994), é a imagem dos movimentos sociais que se opõem a uma dominação em nome da definição histórica do sujeito: o progresso, a Fé, o Indivíduo. "A luta social desenrola-se nas categorias culturais do sujeito: em nome da Fé contra a igreja instituída nas sociedades religiosas, em nome da Razão, contra a tradição no mundo burguês, em nome do trabalho criador, contra a sua exploração na sociedade industrial” (DUBET, 1994, p.133). “A consciência de classe operária encarna mais nitidamente esta lógica da ação, quando não se reduz aos sentimentos de pertença comunitária ou apenas aos interesses dos assalariados, quando é percebida como uma luta do trabalho identificado com uma criatividade privada do seu sentido pela dominação de classe (DUBET, 1994, p.130)”.

$\mathrm{O}$ autor afirma que o movimento operário foi uma figura forte, "consciente e organizada, a de um sujeito formado por categorias historicistas da sociedade industrial, categorias que foram também dos dirigentes que se identificaram do mesmo modo, 'ingenuamente', com o Progresso, a Ciência e a Razão” (DUBET, 1994, p.133). Nesta lógica de ação, o adversário e a ordem social combatidos são designados pelo tema da alienação. Somente esta lógica de ação "permite explicar o que há de 'irracional' e de excessivo nos movimentos sociais: esta ilusão lírica de um dom de si, por vezes levado até o verdadeiro sacrifício, esta euforia, este sentimento de existir plenamente na ação" (DUBET, 1994, p.134). Todo esse universo emocional pode surgir como um momento em que o ator se experimenta como sujeito (DUBET, 1994).

\section{A EXPERIÊNCIA SOCIAL E O SISTEMA}

A designação da noção de experiência social como a combinação subjetiva, realizada pelos indivíduos, de vários tipos de ação remete ao risco de tornar essa noção propriamente subjetiva, concebendo-a como uma vivência meramente flutuante sem relação com o sistema social, ou seja, não torná-la um objeto socialmente não determinado. DUBET (1994) alerta que este perigo deve ser evitado, 
"lembrando que cada uma das lógicas de ação que se combinam na experiência social se inscreve, ela própria, numa objetividade do sistema social” (p.139). A objetividade significa simplesmente que "os elementos simples que compõem a experiência social não pertencem ao ator, mas que são dados, que preexistem a ele ou lhes são impostos por meio de uma cultura, das relações sociais, dos constrangimentos de situação ou de dominação" (p. 139).

A ação, de maneira geral, é considerada uma vertente subjetiva do sistema. Esta afirmação não implica um regresso à sociologia clássica, porque ela não postula necessariamente uma unidade de ação, e a idéia de um princípio comum à ação e ao sistema também não implica a idéia de uma hierarquia funcional das diversas lógicas de ação. "A heterogeneidade dos princípios da ação remete para a do sistema e para a própria heterogeneidade dos mecanismos de determinação das lógicas de ação. É, de resto, esta pluralidade que permite que se fale de ator e não apenas de agente" (DUBET, 1994, p. 140).

Segundo DUBET (1994) “o ator constrói uma experiência que lhe pertence, a partir de lógicas de ação que lhe não pertencem e que lhe são dadas pelas diversas dimensões do sistema que se separam à medida que a imagem clássica da unidade funcional da sociedade se afasta" e ainda que "a formação causal das lógicas de ação não impede a formação de uma experiência autônoma" (p.140).

- Da ação ao sistema

Cada uma das lógicas de ação inscreve-se em um tipo de 'causalidade' e tem a ver com os próprios mecanismos sociais em questão. "A lógica da integração está assentada essencialmente nos processos de socialização que remetem para formas de explicação causal ou estrutural. A ação estratégica está ligada ao sistema pelos constrangimentos de situação e o modo de explicação assenta no modelo do sistema de interdependência. Quanto à subjetivação, ela está socialmente definida pela tensão entre uma representação do sujeito e das relações sociais: neste caso, a sua articulação com o sistema é do tipo dialético" (DUBET, 1994, p.140-141). 


\section{- O sistema de integração e a socialização}

Quando a ação é vista como vertente subjetiva da integração, para explicar as condutas sociais é preciso descobrir os modelos culturais aos quais elas se ajustam e, sobretudo, dizer como os atores os adquiriram e como os conservam. "A socialização, como educação, por um lado, e como controle social, por outro lado, assegura os fundamentos desta lógica da integração" (DUBET, 1994, p.142).

Uma segunda força desse modelo é de ordem epistemológica e metodológica. "Ela permite uma análise causal das condutas sociais, estabelecendo correlações entre os comportamentos e as atitudes dos indivíduos, por um lado, e suas posições sociais, por outro, revelando uma correspondência entre duas séries de fenômenos, uma das quais se mostra objetiva, independente dos atores, e a outra, subjetiva" (DUBET, 1994, p. 144).

\section{- O sistema de interdependência}

"O indivíduo autônomo e racional faz escolhas em função das oportunidades que se oferecem. As correlações observadas entre as situações e as ações não resudas socializações diferenciais, mas das escolhas individuais ligadas a essas situações. Aqui, o modelo do sistema já não é da unidade funcional, mas da interdependência das ações individuais" (DUBET, 1994, p.145). Esta linha de análise é derivada do modelo econômico, é o sistema com efeito de composição, que deriva da ação e não o inverso; "as estruturas provêm da composição das condutas individuais que constituem, por seu turno, situações nas quais as condutas se formam" (DUBET, 1994, p.145).

O princípio de explicação é muito diferente do modelo de socialização, "mas a imagem de uma ação livre não é, no entanto, totalmente aceitável, mesmo que ela esteja no centro de uma definição da ação estratégica. A relação desta ação estratégica com o sistema resulta precisamente do fato de ser limitada à racionalidade do indivíduo" (DUBET, 1994, p. 145). Esta racionalidade é, de fato, uma petição de princípio, que afirma que o ator faz o que é melhor para ele, o sistema é comparável a um mercado (p. 146). 
Exemplificando a racionalidade das opções escolares: "ora se observa que cada aluno não escolheu senão aquilo que pode escolher em função dos seus recursos escolares e sociais, e as boas razões são, então uma consolação, ora cada aluno constituiu os seus recursos em função das suas escolhas iniciais, o que implica uma racionalidade ao longo prazo excepcional e deixa sem resposta o problema da desigual distribuição dos projetos fora de uma causalidade estrutural" (DUBET, 1994, p. 147).

Uma ação que não é redutível a uma aplicação de um programa de socialização não impede que a estratégia se inscreva em coações e em regras de jogo que preexistam em relação aos atores e se impõem a eles. Ao falar de coações estruturais fala-se de uma cultura que permite que se jogue em conjunto. Sendo assim, as estratégias são racionais e as estruturas são culturais. Segundo DUBET (1994), não se pode abandonar a idéia de determinação da ação. Mesmo quando o sistema é definido em termos de interdependência, “ ele impõe regras e coações aos indivíduos. Nesse conjunto de ação só podemos orientar-nos para uma solução mista dominada pela metáfora do jogo, articulando a racionalidade dos atores com a presença de regras e de situações que impõem o jogo e distribuem de modo desigual as capacidades de jogar" (,p. 151).

\section{- O sistema de ação histórico}

DUBET (1994) ressalta que é evidente que a lógica da subjetivação não é o puro produto da socialização, nem a simples utilização de interesses em um espaço de concorrência. $\mathrm{O}$ fato de o ator se afirmar como sujeito, naquilo que é essencial, na crítica, na distância ou no empenhamento, não deve, no entanto, levar a crer que essa espécie de autodeterminação nada deva à sociedade. A representação do sujeito, a alma, a razão, a individualidade e os direitos naturais resultam de uma atividade social, denominada por TOURAINE de historicidade (p.151). "A atividade do sujeito como capacidade ou como desejo de conduzir a sua própria vida implica ao mesmo tempo o apelo a valores e a definição de obstáculos à sua realização. O passado, a dominação e a própria ordem obstam à realização do sujeito que tem a possibilidade de se colocar fora do mundo para fazer a crítica dele" (p. 152). A atividade crítica do 
sujeito não se desenrola em um vazio cultural ou social e, até mesmo nos arcanos das consciências, a introspecção nada mais é do que um diálogo interiorizado.

A atividade crítica do sujeito pode assumir a forma de um movimento social, porque se coloca na tensão entre a cultura e as relações sociais definidas como relações de dominação. Nesse caso, segundo TOURAINE, citado por DUBET (1994), “os movimentos sociais não são redutíveis à defesa de uma comunidade ou uma agregação dos interesses. Eles apelam para a imagem cultural de um sujeito, contra a dominação social ou, de modo mais lato, contra aquilo que obsta à realização social desse sujeito" DUBET, 1994, p.154).O conceito de movimento social, para DUBET (1994) é ambíguo, "porque designa ao mesmo tempo uma lógica da ação resultante da tensão entre uma imagem cultural do sujeito e das relações sociais e uma ação coletiva mais ou menos organizada" (p.154).

"O problema da ação coletiva, como participação e mobilização de ações individuais, e o movimento social, como expressão de uma lógica particular da ação, são analIticamente distintos" (DUBET, 1994, p .154).

\section{- Pluralidade do sistema}

Cada lógica da ação remete para elementos autônomos do sistema social, que designa um arranjo particular dessas lógicas: a do sistema de integração, do sistema de interdependência e do sistema de ação histórico. A heterogeneidade das lógicas da ação conduz a conceber a sociedade:

como um conjunto desprovida de centro em que não existe regulação ao nível de toda sociedade, sendo aberta à reunião dos seus elementos. Não há concordância entre a totalidade e o sentido subjetivo da experiência. Do mesmo modo que a experiência social é uma combinação de lógicas de ação cujo sentido provém de um trabalho do indivíduo, assim aquilo que se chama 'o sistema social' ou 'a sociedade' é uma combinação de elementos cuja unidade resulta da capacidade política dos atores (DUBET, 1994, p.156).

Epistemologicamente, a diversidade das lógicas da ação leva a aceitar uma diversidade de tipos de explicação, "porque a definição de natureza de um sistema não é somente uma representação da realidade, ela é também uma escolha de inteligibilidade - de inteligências do social” (DUBET, 1994, p.157). 


\section{SUJEITO SOCIAL}

Como vimos nas reflexões apresentadas, a sociologia clássica estuda a sociedade como uma "unidade funcional", analisa as funções sociais, as normas, os valores e os interesses em jogo na sociedade e não se interessa pela subjetividade, pois cabe ao indivíduo apenas interiorizar as normas e os valores sociais. No entanto, hoje não podemos mais nos satisfazer com esta idéia clássica da sociologia, pois a sociedade não pode mais ser considerada como um sistema unificado (DUBET, 1994). O conjunto social atualmente está formado pela presença simultânea dos três sistemas, cada um regido por uma lógica diferente: "uma "comunidade", estruturada pela lógica da integração, um ou mais mercados competitivos, dependentes de uma lógica da estratégia e um sistema cultural correspondendo a uma lógica da subjetivação" (CHARLOT, 2000, p. 39). Sendo assim, a unidade do indivíduo também passa a ser construída, o ator é obrigado a articular lógicas de ação diferentes e a dinâmica gerada por essa atividade é que constituirá a subjetividade e a reflexividade. Dessa forma a experiência social é a combinação subjetiva, realizada pelos indivíduos dos diversos tipos de ação (DUBET, 1994).

Conforme CHARLOT (2000), DUBET (1994) "estuda as formas sociais da subjetividade e a tomada de consciência reflexiva de cada um como sujeito" (p. 44). Assim, DUBET procura constituir a subjetividade como categoria sociológica, sem "ter que admitir o sujeito enquanto objeto de análise do sociólogo (p .44). Neste caso, o sujeito não é o objeto de análise da sociologia, o seu objeto é a subjetivação, ou seja, o distanciamento, "o sujeito não é senão uma hipótese em que o sociólogo é levado a aventar quando constata a existência de um processo de subjetivação: se há um processo de subjetivação, esse cria algo que havemos de designar como um sujeito" (CHARLOT, 2000, p. 43).

Para CHARLOT (2000), o sujeito é uma outra lógica, específica, “ o sujeito não se soma dos Eus sociais interiorizados, não se distancia deles, não luta contra eles. O sujeito apropria-se do social sob uma forma específica, compreendidos aí a sua posição, seus interesses, as normas e os papéis que lhe são propostos ou impostos" (p. 43). O sujeito, segundo o autor, é definido como "um ser singular que se apropria do social sob uma forma específica, 'transformada' em representações, 
comportamentos, aspirações, e práticas. Nesse sentido, o sujeito tem uma realidade social que pode ser estudada, analisada, de outra maneira, não em termos de diferença ou distância" ( p.43).

Sendo assim, conforme CHARLOT (2000), o sujeito é:

- "um ser humano, aberto a um mundo que não se reduz ao aqui e agora, portador de desejos movidos por esses desejos, em relação com os outros seres humanos, eles também sujeitos;

- um ser social, que nasce e cresce com a família (ou em um substituto da família), que ocupa uma posição no espaço social que está inscrito em relações sociais;

- um ser singular, exemplar único da espécie humana, que tem uma história, interpreta o mundo, dá sentido a esse mundo, à posição que ocupa nele, às suas relações com os outros, à sua própria história, à sua singularidade”(p.33). Portanto, o sujeito: “age, no e sobre o mundo; encontra a questão do saber como a necessidade de aprender e como presença no mundo de objetos, pessoas e de lugares portadores de saber; se produz ele mesmo, e é produzido, através da educação" (CHARLOT, 2000, p. 33).

Podemos constar que são várias as formas de pensar o sujeito. Muitas vezes a noção é utilizada sem a preocupação de defini-la, como se fosse consensual a compreensão de seu significado (DAYREL, 2003). Outras vezes, a noção é tomada como sinônimo de indivíduo ou de ator social.

A noção de sujeito como ator social está presente na definição de CASTELL (1999). Conforme o autor, "sujeitos não são indivíduos, mesmo considerando que são constituídos a partir dos indivíduos. São o ator social coletivo pelo qual indivíduos atingem o significado holístico em sua experiência" (CASTELLS, 1999, p. 26). Dessa forma, segundo o autor, a construção da identidade consiste "em um projeto de vida diferente, talvez com base em uma identidade oprimida, porém expandindo-se no sentido da transformação da sociedade como prolongamento desse projeto de identidade" (CASTELLS, 1999, p.26). 
TOURAINE (2007) apresenta uma noção diferente, chama de sujeito o desejo de ser um indivíduo, de criar uma história pessoal, e atribuir significado a todo um conjunto de experiências da vida individual.

Conforme TOURAINE (2007, p. 130), para que se forme esta consciência de sujeito, é preciso que apreçam e se combinem três componentes: primeiramente "uma relação a si mesmo, ao ser individual, como portador de direitos fundamentais, o que marca uma ruptura em relação à referência a princípios universalistas ou mesmo a uma lei divina. O sujeito é o seu próprio fim”. Em segundo lugar, o sujeito não se forma a não ser entrando conscientemente em conflito com as forças dominantes que lhes negam o direito e a possibilidade de agir como sujeito. Por último, "cada um, enquanto sujeito, propõe uma certa concepção geral do indivíduo".

Segundo TOURAINE (2007), “o sujeito se forma na vontade de escapar às forças, às regras, aos poderes que nos impedem de sermos nós mesmos, que procuram reduzir-nos ao estado de componente de seu sistema e de seu controle sobre a atividade, as intenções e as interações de todos. Estas lutas contra o que nos rouba o sentido de nossa existência são sempre lutas desiguais contra um poder, contra uma ordem. Não há sujeito senão rebelde, dividido entre raiva e esperança" (TOURAINE, 2007, p.119).

Neste estudo, tomaremos a definição de CHARLOT (2000), na qual o sujeito é um indivíduo que ocupa uma posição na sociedade e que está inserido nas relações sociais e que constrói o seu mundo singular tendo como referência lógicas de ação heterogêneas.

Pressupondo que juventude é um momento rico em manifestações de sociabilidade, observa-se que na sociedade global a socialização do jovem está se produzindo em ambientes onde as trocas culturais criam novos estilos de se vincular com o mundo, de decidir e enfrentar problemas (SPÓSITO, 1997). Nesse contexto, no âmbito da teoria da ação, considera-se que é necessário identificar o sentido que os autores dão para a ação coletiva. O processo de construção de sentido envolve o campo de ação coletiva e simbólico, e é no espaço da vida, no cotidiano, que se constrói e se dá sentido a ação, e nos tornamos "Nós". É impossível pensar a ação coletiva sem pensar o indivíduo (MELUCCI, 2002). Entretanto, segundo o autor estamos em um momento de ausência de ação coletiva, portanto precisamos entender 
a experiência no cotidiano e olhar o indivíduo a partir da articulação da lógica estratégica, integrativa e da subjetividade, conforme referencial de DUBET, 1994; SCHALLER, 2002).

SCHALLER (2002), apoiado em DUBET (1994), propõe, então, a análise da experiência social por meio das três "lógicas da ação": a estratégica , a integração e a subjetivação. Proposta que pretendemos adotar para a realização da análise.

Cada uma dessas lógicas se desenvolve em uma esfera da vida social - o mercado, as instituições e as representações do indivíduo. Segundo o autor, este é o ponto de partida que devemos tomar para isolá-las e construir um estado dos lugares. Em vez de partir da ordem estabelecida, dos valores e de suas normas, de sua definição do status de papéis, devemos partir da dialética da ação histórica.

A identidade não nasce somente da consciência das contradições, mas também da busca do controle da transformação social "a busca da identidade não é um comportamento reflexivo, nem a descoberta das coordenadas sociais, do status, dos papéis assumidos; ela é o nascimento de um movimento social, ela é o movimento do nascimento do sujeito" (SCHALLER, 2002, p.154).

De acordo com o autor, a construção do sujeito se dá na tensão entre a identidade integrativa e a identidade conflitual, indicando que qualquer reconhecimento da ação do ator passa por sua inscrição em uma relação social. Trata-se, portanto, de criar novas relações sociais, "desdramatizar" o cotidiano, tendo como ponto central a capacidade de cada um produzir a própria vida.

A identidade integrativa indica o nível de interiorização que cada ator tem de um sistema social dado. A identidade conflitual visa a uma ordem, a uma dominação e não apenas a uma simples definição de si mesmo. Assim, uma busca de integração passa pela mediação do conflito, na busca expressiva da relação social. Essa abordagem teórica implica, pedagogicamente, dar prioridade à identidade conflitual sobre a identidade integrativa. É pelo conflito que o autor jovem tornase apto a construir e a integrar.

Segundo SCHALLER (2002), do ponto de vista da análise e da ação dos atores da intervenção social, ainda é a norma social que deve ser interrogada. Esses espaços devem permitir uma expressão das condutas sociais e coletivas que nunca estão em concordância com o conjunto das normas tomadas como tal. "Por trás dos 
lugares de exclusão e de isolamento, se perfilam lugares de misturas sociais, de trocas de sociabilidade (p.160).

Para o autor, é preciso apoiar-se nas redes sociais de solidariedade e favorecer os movimentos esporádicos ou associativos nos lugares e nos bairros. A maneira de pensar a cidadania inclina-se para as diferentes possibilidades de viver juntos. "Para construir uma perspectiva de ação, devemos, então deixar de lado as faltas e os déficits para tentar uma abordagem que busca captar os processos em construção no cotidiano dos habitantes (p.161).

Por trás da relação entre identidade integrativa e conflitual, desponta a construção do sujeito, definida "como a vontade, a capacidade de cada indivíduo de participar, ativamente e conflitualmente, na criação da vida social" (SCHALLER, 2002, p.161).

Os fenômenos juvenis contemporâneos comportam um entrelaçamento do coletivo e do individual, constituindo a chave para compreender o que acontece nos grupos da juventude. A experiência dos jovens são construídas, em grande parte, nas redes de relações e no significado da cultura global. Cada vez mais os jovens se vêem obrigados a realizar seus planos de vida sem as referências tradicionais. No entanto, os indivíduos tomam consciência de sua individualidade a partir do olhar do outro, em um processo "intersubjetivo em que eu sou para ti o que tu és para mim" (MELUCCI, 1992). Portanto, quando se fala em identidade juvenil, "é preciso investigar onde os jovens estão construindo os nexos emocionais, onde e como estão buscado esse reconhecimento intersubjetivo e onde eles estão tomando consciência de sua individualidade, pois nós o fazemos no encontro com o outro"(SOUZA, 2004, p.67). 


\section{A CONCEPÇÃO DE PROMOÇÃO DA SAÚdE PARA O ENTENDIMENTO DA RELAÇÃO JUVENTUDE E VIOLÊNCIA}

À noção de experiência social relacionaremos outros conceitos que colaboram para explicar de que forma o jovem se desenvolve em um contexto, ou se conforma com as situações ou perfis de relação que predispõem à violência, especialmente na periferia das grandes cidades.

A promoção da saúde tem como objetivo central que os indivíduos e setores sociais aumentem o controle sobre os determinantes do processo saúde-doença, ou seja, fortaleçam-se na luta para a melhoria das condições de vida. O desafio imposto consiste no questionamento dos mecanismos de produção social da saúde e qualidade de vida no contexto da globalização. Ao mesmo tempo, implica uma abordagem local das necessidades dos jovens considerados em sua integralidade e o atendimento ou frustração em relação a essas necessidades, nas relações sociais de que participa. Nesse processo, inclui-se a demanda da população concernente, suas alegrias, seu sofrimento, sua história e a consideração sobre sua importância para a formação da identidade. Estas questões poderão ser recuperadas na descrição e análise da vida cotidiana.

O papel da promoção da saúde em relação ao jovem é o de favorecer a redescoberta ou a recriação do elo social, da relação social, e promover transformações para melhoria das condições de vida e enfrentamento da violência social.

Isto implica reconhecer as necessidades e as potencialidades dos jovens e do território. A abordagem das necessidades remete à percepção da falta que, segundo MELLUCCI (2004), parece ser uma das alavancas mais poderosas do comportamento humano. A necessidade é um produto da cultura: "a cultura é o universo simbólico que contém os gestos, as ações e as palavras, com os quais é possível definir as experiências fundamentais da falta, isto é: o limite, a morte e a alteridade" (MELLUCCI, 2004, p. 38).

Segundo o autor, é impossível falar de necessidades em termos puramente naturais; "não existe necessidade biológica que não esteja organizada dentro de uma linguagem e de relações sociais. Cada necessidade humana foi transformada em uma 
construção interpessoal e social que exprime pela linguagem a percepção da falta e a tensão para superá-la" (MELLUCCI, 2004, p.39). Cada vez que definimos uma necessidade, estabelecemos uma ponte entre a experiência subjetiva profunda, principalmente sensorial, e uma rede de relações sociais à qual pertencemos. Considerando que a definição de necessidades sempre foi um produto da cultura, hoje torna-se ainda mais evidente ser também o resultado de uma construção social (MELUCCI, 2004, p.40). "Para poder reconhecer nossas necessidades como indivíduos, precisamos estar integrados às redes comunicativas que lhes dão origem. O grupo torna-se a regra obrigatória em que precisamos nos inserir para saber quem somos." (MELUCCI, 2004, p. 41).

A experiência da falta leva ao questionamento de nós mesmos. É difícil falar de identidade sem fazer referência às suas raízes sociais e relacionais. A identidade adulta é, portanto, "a capacidade de produzir novas identidades, integrando passado e presente, além dos múltiplos elementos do presente na unidade e continuidade de uma história individual. A aprendizagem não termina com o fim da idade evolutiva, e as diversas vivências da vida nos levam sempre a questionar e reformular nossa identidade" (MELUCCI, 2004, p. 46).

No âmbito coletivo podemos falar de identidade como aquilo "que assegura ao grupo, ou à sociedade à qual pertencemos, a continuidade e a preservação. A identidade estabelece, no tempo, quais são os limites de um grupo em relação ao seu ambiente natural e social" (MELUCCI, 2004, p. 47).

Segundo MELUCCI (2004), as noções de consistência, conservação de limites, reconhecimento e reciprocidade descrevem nossa identidade em termos estáticos. No seu aspecto dinâmico, "a identidade apresenta-se como um processo de individuação e de crescimento da autonomia" (MELUCCI, 2004, p. 47). Ela é produto de uma ação consciente e resultado da auto-reflexão, mais do que um dado ou uma herança. Ela "é vivida mais como uma ação do que como uma situação. A própria palavra 'identidade' é inadequada para expressar essa mudança e seria melhor falar de identização para expressar o caráter processual, auto-reflexivo e construído da definição de nós mesmos” (MELUCCI, 2004, p. 48) .

Segundo MELUCCI (2004), se considerarmos ser verdade que a identidade está fundamentada na relação social, e depende da interação, do reconhecimento 
recíproco entre nós e os outros, então ela contém uma tensão irresoluta e irresolúvel entre a definição de nós mesmos e o reconhecimento dado pelos outros. Dessa forma, exceto os objetos concretos, materiais e simbólicos, que podem estar em jogo em um conflito, o motivo pelo qual nos enfrentamos é sempre a possibilidade de nos reconhecermos e sermos reconhecidos como sujeitos da nossa ação. "Entramos em um conflito para afirmar nossa identidade, negada por nosso opositor, para nos reapropriar daquilo que nos pertence, porque estamos aptos a reconhecê-lo como nosso" (MELUCCI, 2004, p. 49).

Para o autor, toda vez que, em uma situação de conflito, encontramos a solidariedade de outros e nos sentimos parte de um grupo, nossa identidade é reforçada e garantida. É pela solidariedade que nos ligamos aos outros; é através dela que podemos nos afirmar como sujeitos da nossa ação e suportar a ruptura que o conflito insere nas relações sociais (MELUCCI, 2004). “A participação em ações de mobilização coletiva e em movimentos sociais, o engajamento em atividades de inovação cultural e ações voluntárias de cunho altruísta assentam seus alicerces sobre essa necessidade de identidade e contribuem para respondê-la" (MELUCCI, 2004, p. 49).

A promoção da saúde, conforme preconizada na Carta de Otawa (1986), começa com a participação efetiva e concreta da comunidade na eleição de prioridades, na tomada de decisões e na elaboração e desenvolvimento de estratégias para alcançar melhor nível de saúde. A promoção da saúde consiste em um processo de capacitação da população para identificar seus problemas de saúde e suas causas, a fim de que se definam os meios necessários para melhorar a saúde e exercer maior controle sobre ela. A promoção da saúde pode, portanto, ser entendida como uma estratégia de formação de identidade, que pressupõe o conflito, com base nas diferenças de interesses, mas é uma ação de negociação e solidariedade para enfrentá-lo. (COMARÚ, 2004).

Os indivíduos constroem-se socialmente por meio das experiências sociais, pela capacidade de articular os três tipos de lógicas de ação; integração, estratégia e subjetivação, em uma dinâmica que leva à constituição da subjetividade do ator e sua reflexividade. É a experiência social que articula o trabalho do indivíduo, que constrói sua identidade, uma coerência, e dá um sentido às suas ações sempre 
dialogando com as lógicas que já se encontram determinadas (DUBET, 1997 e DAYRREL, 2002). Portanto “a socialização e a formação dos sujeitos são entendidas como o processo mediante o qual os atores constroem sua experiência, evidenciando uma equação, na qual os indivíduos se constroem e ao mesmo tempo são construídos socialmente" (DAYRREL, 2002, p.121).

A saúde é um conceito positivo que enfatiza os recursos sociais e pessoais; assim, a promoção da saúde não é responsabilidade exclusiva do setor saúde e vai além de um estilo de vida saudável, na direção de um bem-estar global. Entendendoa desta forma, acreditamos que, para ativar cada uma de suas estratégias ou campos de ação, é necessário um diagnóstico, isto é, tentar entender os sentidos das relações sociais, das ações coletivas nas micro-esferas públicas. Esses dados, ou melhor, esse reconhecimento, pode revelar o potencial de ação da comunidade em relação aos jovens, dar visibilidade e fortalecer as redes sociais existentes, para resistirem à violência e promoverem a paz, nas condições de vida que os jovens, sujeitos das pesquisas, vivem e se desenvolvem.

Refletir sobre participação e subjetividade é procurar compreender por que estão crescendo no mundo contemporâneo as reações de passividade e tolerância com os sofrimentos alheios, tão favoráveis ao desenvolvimento da violência e não da paz, em detrimento das ações coletivas, da indignação contra as injustiças e da solidariedade entre as pessoas. Essas reflexões não têm sido feitas pelos responsáveis por elaborar e estabelecer políticas públicas para a paz e não violência nem gerado movimentos sociais por direitos. A questão ainda tem sido o maior investimento do Estado na repressão da violência e a maior cobrança da população. A Promoção da Saúde, com o conceito positivo de saúde a partir do qual organiza suas ações, está preocupada em desvendar a questão da violência, problematizá-la, focalizando os fatores que interferem na formação da identidade dos jovens.

O desafio deste trabalho, portanto, é compreender a partir de que lógicas se desenvolvem as ações coletivas e suas dimensões objetivas e subjetivas para promoção da saúde e da qualidade vida do jovem. Compreender as intervenções no campo da educação para valores e da promoção da cidadania significa atuar do lado positivo da promoção da vida: antídoto da violência. 


\section{O REFERENCIAL TEÓRICO CONSTRUÍDO PARA}

\section{ANÁLISE}

No diagrama abaixo, com base nos estudos de LABONTE (1996); CHIESA (2001); WESTPHAL (2001); ÁVILA (2002); e com a colaboração dos resultados dos estudos de DUBET (1994), CHARLOT (2000), MELLUCCI (2004), e TOURAINE (2007), que acabamos de discutir, construímos um referencial teórico explicativo para análise na perspectiva da promoção da saúde, para o crescimento e desenvolvimento dos jovens e para a sua formação como sujeito social, considerando os aspectos que podem interferir na configuração de paz ou violência contra eles.

No diagrama podem ser visualizadas três dimensões da saúde: física, social e emocional com suas diferentes causalidades. As interfaces entre essas dimensões e os produtos da interação entre elas constituem o poder que $\mathrm{o}$ jovem pode gradativamente obter para lidar com as adversidades e ter controle sobre elas e sobre a própria vida.

LABONTE, citado por ÁVILA (2002), ao discutir um referencial para a Promoção da Saúde, descreve que da dimensão física emana uma energia vital para que o jovem possa partilhar a vida comunitária ou melhorar os tipos de relações com a família, grupos e instituições sociais. Nessa interação, entram necessidades e potencialidades, que são moldadas gradativamente pelas experiências pessoais no território concebido como uma produção social. Para MELLUCCCI (2004), existe uma seqüência temporal no decorrer da vida, cuja maturação biológica faz emergir determinadas potencialidades. Assim a criança e o jovem vão gradualmente conquistando independência, dando provas de auto-suficiência, dentre outros sinais corporais e psicológicos e adquirindo controle sobre a própria vida.

A produção do ser humano se coloca no limite entre a natureza e a cultura. A dimensão biológica e a social influenciam-se mutuamente na produção humana. $\mathrm{O}$ ser humano se constitui tanto por meio do desenvolvimento biológico, em especial do sistema nervoso, quanto pela qualidade das trocas que se dão entre os homens no meio em que vive. As dimensões biológica, social e cultural estão totalmente interligadas e se desenvolvem com base nas relações que se estabelecem com o outro, no meio social em que cada um se insere. 
Aos poucos, os jovens elaboram um projeto de vida que dê sentido a própria existência e acionam os movimentos para concretizá-lo. $\mathrm{O}$ processo de desenvolvimento do jovem e a formação da sua identidade incluem o contato com diferentes grupos e instituições (vida comunitária) e ações coletivas por meio dos quais sua socialização vai ocorrendo. Em meio a conflitos e acordos com a participação nos espaços públicos e privados existentes no território, os jovens vão aprendendo ou encontrando caminhos para exercer controle sobre a própria vida, ter relações sociais satisfatórias e desenvolver habilidades para concretizar projetos, adquirir autonomia, construindo-se como sujeitos sociais.

O conceito de autonomia, no âmbito da educação em saúde, é considerado na perspectiva de processos emancipatórios voltados para o fortalecimento dos sujeitos (CHIESA, 2005, 1999; WESTPHAL, 1999; WALLERSTEIN,1994).

O diagrama procura mostrar também que o crescimento e desenvolvimento do jovem resulta da interação constante entre o processo de desenvolvimento biológico, social, cultural e emocional, intimamente relacionados às tendências socioeconômicas e subordinados à evolução de normas e valores, dentro de culturas específicas, no território e na sociedade.

Dessa forma, construímos o diagrama I, que ilustra o referencial teórico utilizado para análise. 


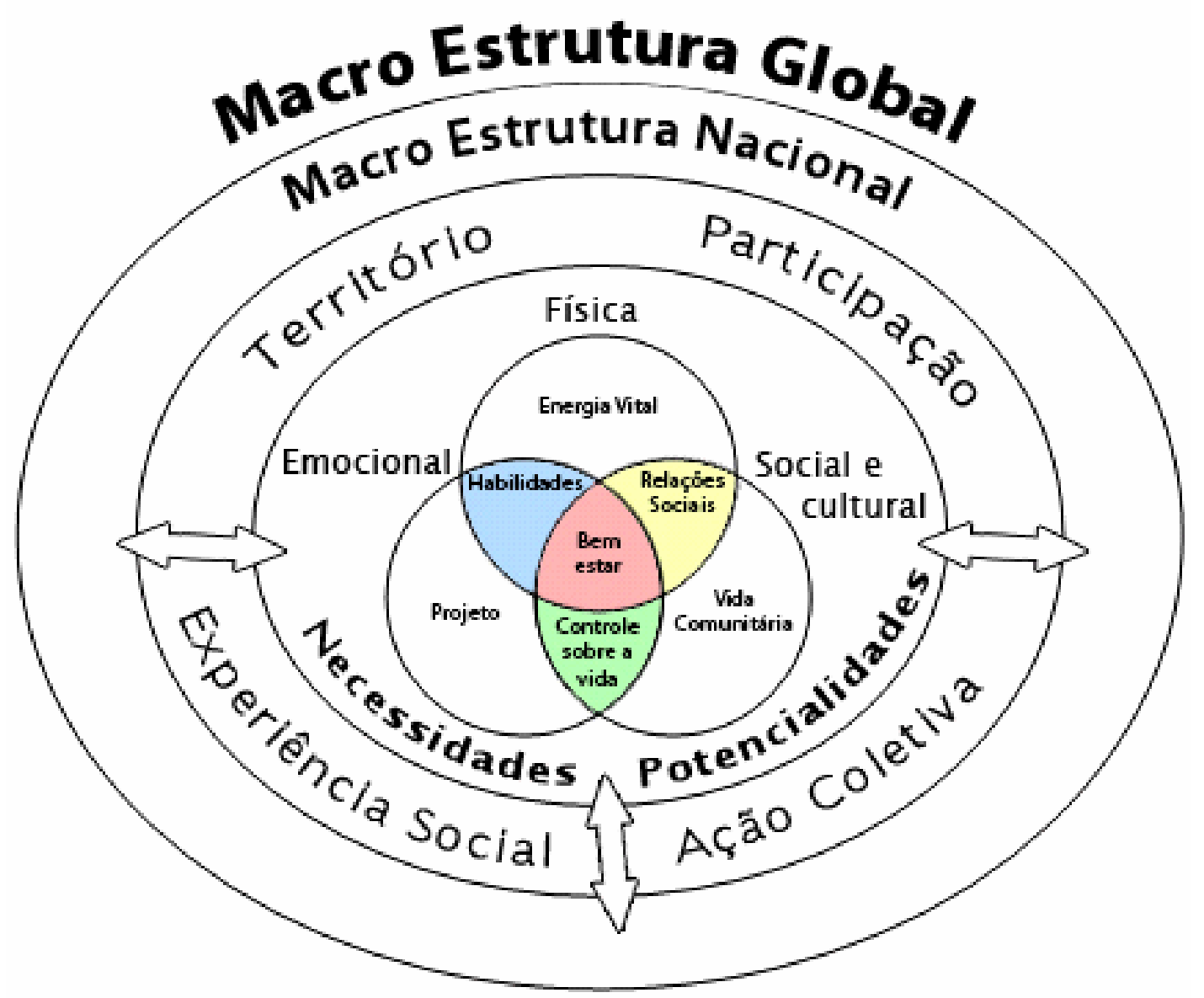

\section{METODOLOGIA}

\subsection{A CONCEPÇÃO DA PESQUISA}

De acordo com MINAYO (1999, p. 22), a metodologia deve incluir as concepções teóricas que fundamentam a análise, as técnicas ou conjunto de técnicas utilizadas para compreender a realidade e o potencial criativo do pesquisador. Este último item refere-se ao esforço de compreensão dos dados empíricos à luz da teoria que fundamenta a pesquisa. 
Com o objetivo de atender a esses requisitos, e tendo como objeto de estudo as ações sociais, os sentidos e as representações dos adolescentes, pais, lideranças, profissionais das áreas da educação, da saúde e gestores das subprefeituras sobre suas experiências para enfrentamento da violência, utilizamos o método qualitativo de pesquisa.

A fim de aprofundar o conhecimento dos problemas que afetam a juventude, a situação de violência nas duas regiões de estudo, as ações coletivas e as redes de proteção, foi utilizado o estudo de caso.

A técnica do estudo de caso consiste em relacionar uma situação real tomada em seu contexto e a partir da análise verificar como se manifestam e evoluem os fenômenos pelos quais o pesquisador se interessa (MUCCHIELLI, 1996). Tem como características: a descoberta; enfatiza a interpretação em contexto; busca retratar a realidade de forma complexa e profunda; usa uma variedade de fontes de informação; revela a experiência e permite generalizações; procura confrontar os diferentes e às vezes conflitantes pontos de vista presentes em uma situação social e costuma utilizar uma linguagem mais acessível do que outros tipos de relatório de pesquisa (LÜDKE \& ANDRÉ ,1986)

O estudo de caso é caracterizado, de acordo com NISBET E WATT referidos por LÜDKE \& ANDRÉ (1986), em três fases. A primeira fase é chamada de aberta ou exploratória; a segunda é mais sistemática em termos de coleta de dados; e a terceira é a análise dos dados e elaboração do relatório. Conforme os autores, essas três fases se superpõem em diversos momentos, e muitas vezes se torna difícil precisar as linhas que as separam.

A fase exploratória é fundamental para a definição mais precisa do objeto de estudo. É nesse momento que se especificam os pontos críticos, estabelecem-se os contatos iniciais, localizam-se os informantes e as fontes de dados necessários para a realização do estudo.

Identificados os elementos-chaves e os contornos aproximados do problema, procede-se à delimitação do estudo e à coleta sistemática de informações, com a utilização de instrumentos mais ou menos estruturados e técnicas variadas, cujas escolhas são determinadas pelas características próprias do objeto estudado. Determinar os focos da investigação e estabelecer os contornos do estudo é 
importante, uma vez que nunca será possível explorar todos os ângulos do fenômeno em um tempo limitado. Selecionar os aspectos mais relevantes e determinar o recorte é crucial para atingir os propósitos do estudo de caso e chegar à compreensão mais completa da situação estudada (LÜDKE \& ANDRÉ,1986).

A análise dos dados e a elaboração do relatório já têm início na fase exploratória, com a necessidade de juntar, analisar e tornar disponíveis as informações aos informantes para que manifestem suas reações sobre a relevância e a acuidade do que foi relatado.

O estudo de caso utilizado para desenvolver a pesquisa compreendeu a articulação de várias técnicas, como entrevistas individuais e levantamentos de dados secundários de caráter quantitativo. Para a análise, a estratégia metodológica utilizada foi a triangulação dos dados coletados, o que permitiu analisar a validade das informações e o conhecimento do contexto de onde emergem os fatos, as falas e as ações dos sujeitos (MINAYO, 2005).

\subsection{O DESENVOLVIMENTO DO ESTUDO DE CASO}

\subsubsection{Fase Exploratória - Seleção das áreas de estudo}

Para a escolha das duas regiões com maiores índices de mortalidade por causas externas, procedeu-se ao levantamento dos homicídios ocorridos no município de São Paulo, na faixa etária de 15 a 19 anos, no período de 1996 a 2004. A partir desse levantamento, foram agrupadas as regiões que, nesse período, apresentaram os maiores números de óbitos por homicídios, segundo o Distrito Administrativo de Residência e faixa etária, com base no Proaim - Programa de Aprimoramento sobre Informações de Mortalidade no Município de São Paulo, e população (IBGE, 2000).

Dessa forma, verificou-se que as regiões que, até o momento, apresentavam o maior número de óbitos por homicídio eram o Distrito Administrativo do Grajaú (DA Grajaú), com 51 óbitos e com coeficiente de mortalidade em 2004 de 14,0/10mil/hab., e o Jardim Ângela, que em 2002 apresentou 48 óbitos e coeficiente de mortalidade por homicídio na faixa etária de 15 a 19 anos de 18,8/10 mil hab. Verificamos que o número de óbitos para a faixa etária de 15 a 19 anos no DA 
Jardim Ângela vinha diminuindo (24 óbitos), sendo o coeficiente de mortalidade por homicídio apresentado em 2004 de 9,7/10.000 hab. (SMS/ CRSSUL, 2005).

Com base nesse levantamento, para o estudo de caso, definimos os Distritos Administrativos do Grajaú e Jardim Ângela. Outro dado importante, para a tomada de decisão foram as explicações verbais obtidas nas regiões sobre as diferenças existentes na diminuição do coeficiente de mortalidade por homicídio. Havia uma "lenda" de que as ações no Jardim Ângela eram integradas, isto é, a Sociedade dos Santos Mártires havia conseguido mobilizar várias instituições e entidades atuantes no território para uma ação conjunta e com isso obteve-se um melhor resultado na diminuição dos coeficientes de mortalidade por homicídio entre os jovens, especialmente os do sexo masculino. Se a existência de ações intersetoriais se confirmassem, e também essa diferença, conseguiríamos comprovar nossa hipótese de pesquisa.

11.2.1. Entrevistas com informantes chaves das instituições que atendem adolescentes para construção gradual da amostra

Nessa fase foi efetuado o levantamento dos projetos e ações desenvolvidos e sistematizadas as informações existentes. Esse levantamento foi realizado, inicialmente, junto às subprefeituras e Supervisões Técnicas de Saúde de M`Boi Mirim e da Capela do Socorro, partindo-se de uma listagem inicial fornecida pelas subprefeituras locais e pelas Supervisões Técnicas de Saúde, totalizando 385 entidades no DA Grajaú e 113 na região de M'Boi Mirim.

Por meio de contatos telefônicos, partindo de um roteiro definido, foram feitos contatos com as entidades para verificar quais projetos e ações destinados aos adolescentes da faixa etária de 10 a 19 anos existiam nas regiões de estudo para posteriormente agendar entrevista com os responsáveis pelas entidades.

\subsection{PROCEDIMENTOS PARA A COLETA DE DADOS}

Para a coleta de dados, foram realizados, pela pesquisadora, treinamentos dos entrevistadores selecionados para participar da pesquisa e pré-testes dos formulários fora das regiões de estudo. Após essa etapa, foram realizadas as análises em conjunto 
com os entrevistadores, identificando os erros de preenchimento dos formulários, questionários e outras falhas a fim de melhorar a consistência dos dados.

\subsubsection{Técnicas de Coleta de Dados}

A pesquisa foi desenvolvida em seis fases e, para a coleta de dados do estudo de caso, foram utilizados vários procedimentos, entre eles: análise de documentos, análise de dados secundários, entrevista com auxílio de formulário e questionários auto-aplicativos.

\subsubsection{Composição da Amostra}

Participaram do estudo lideranças, pais dos jovens que não freqüentam a escola, jovens que não freqüentam mais a escola, profissionais de saúde, educadores, jovens estudantes e subprefeitos, conforme Tabela 1.

A composição das subamostras para a realização dos discursos do sujeito coletivo dos jovens estudantes e dos jovens que não freqüentam mais a escola foi feita por sorteio. A partir dos levantamentos de campo junto aos jovens estudantes e dos jovens que não freqüentam mais a escola, o Discurso do Sujeito Coletivo - DSC foi realizado com uma amostra do primeiro grupo (jovens estudantes) pareada com as do segundo grupo (jovens que não freqüentam mais a escola), resultando em 75 casos para cada condição. O tipo de sorteio da amostra de jovens estudantes foi o sistemático por partida aleatória do rol de alunos nessa condição, resguardada a proporcionalidade territorial, ou seja, quantidade igual de alunos dos distritos do Grajaú e Jardim Ângela. 
Tabela 1. Composição da amostra segundo as fases da pesquisa - DA Grajaú e Jardim Ângela - São Paulo, 2008

\begin{tabular}{lrrr}
\hline \multirow{2}{*}{ Pesquisa com } & \multicolumn{2}{c}{ Distrito } & \\
\cline { 2 - 3 } & \multicolumn{1}{c}{ Grajaú } & Jardim Ângela & Total \\
\hline Jovens na escola & 316 & 147 & 463 \\
Jovens Fora da Escola & 36 & 41 & 77 \\
Pais de jovens fora da escola & 24 & 28 & 52 \\
Escolar & 46 & 24 & 70 \\
Lideranças & 20 & 33 & 53 \\
Saúde & 12 & 21 & 33 \\
Gestores das Subprefeituras & 5 & 5 & 10 \\
Instituições que constituem Rede & 92 & 70 & 162 \\
\hline
\end{tabular}

Fase 1 - Caracterização da região por meio de dados secundários

Foi realizada a caracterização das regiões estudada: dados demográficos, socioeconômicos, de saúde, educação e condições de vida coletados junto ao IBGE, Fundação Seade, Secretarias e subprefeituras.

Fase 2 - Entrevistas com as lideranças e entidades de proteção e apoio com projetos para os jovens dos Distritos Administrativos do Grajaú e do Jardim Ângela

Selecionadas as entidades com projetos destinados aos jovens das duas regiões, foi realizada a pesquisa, com a utilização de um formulário, com a finalidade de direcionar o diálogo entre entrevistador e entrevistado, registrar as informações obtidas e conhecer com profundidade os projetos e ações existentes (Anexo 1 e 2).

\section{Fase 3. Pesquisa Domiciliar}

A pesquisa domiciliar foi dividida em duas etapas:

Etapa I - Entrevista com os pais dos jovens que não freqüentam mais a escola (fora da escola) identificados nas áreas de abrangência das equipes de Saúde da família

Etapa 2 - Entrevistas com os jovens que não freqüentam mais a escola (fora da escola) identificados nas áreas de abrangência das equipes de Saúde da Família

A entrevista com pais e adolescentes considerados "fora da escola" foram realizadas no domicílio, nas micro-áreas de responsabilidade dos Agentes 
Comunitários de Saúde, por entrevistadores treinados, que utilizaram instrumentos especialmente preparados e testados. O objetivo foi identificar e analisar as construções sociais e as percepções sobre o que é ser jovem, as condições de vida e de desenvolvimento dos jovens e de suas famílias, e sua relação com a violência. Junto aos jovens, identificamos também as percepções sobre violência e paz (Anexo 3 e 4$)$.

Encontramos, na região do Grajaú, cinco Unidades Básicas de Saúde com Programa de Saúde da Família - PSF, totalizando 29 equipes e, no DA do Jardim Ângela, 18 Unidades com 114 equipes. Selecionamos duas Unidades de Saúde com Programa de Saúde da Família em cada região de estudo.

O critério utilizado foi a escolha de uma unidade localizada em área de maior vulnerabilidade social e uma unidade localizada em áreas consideradas de menor vulnerabilidade em cada região, sendo essas indicadas pelos técnicos de Coordenadoria de Desenvolvimento e Assistência Social das Subprefeituras e pelas Supervisões Técnicas de Saúde.

Considerando que no D A Grajaú todas as Unidades do Programa Saúde da Família estão localizadas em áreas de maior vulnerabilidade, foram selecionadas uma unidade localizada em região mais periférica e uma unidade localizada em região mais central do distrito. Sendo assim, participaram da pesquisa as Unidades de Saúde Jardim Gaivotas e Jardim Três Corações. No DA do Jardim Ângela, a Unidade de Saúde situada em uma região mais central, Jardim Coimbra, e na área de maior vulnerabilidade social, a Unidade de Saúde Aracati/ Cidade Ipava.

A partir da autorização da Coordenadoria Regional de Saúde Sul e dos Supervisores Técnicos de Saúde, foram feitos contatos com os Coordenadores de Saúde das Unidades selecionadas para apresentar a proposta da pesquisa e obter a autorização para a sua realização. Foram realizadas reuniões com os Coordenadores de Saúde e as equipes de Saúde da Família das Unidades selecionadas para apresentar a pesquisa e solicitar a colaboração das Equipes de Saúde da Família, principalmente dos ACS, para identificar os pais dos jovens que não frequientam mais a escola cadastrados na Unidade. 
Os Agentes Comunitários de Saúde - ACS indicaram as famílias que tinham filhos na faixa etária de 10 a 19 anos, fora da escola, e o pesquisador percorria a micro- área do ACS, para realizar a pesquisa com os pais e com os adolescentes. $\mathrm{Na}$ maioria das vezes, o ACS acompanhava o pesquisador. Muitas vezes, o entrevistado indicava outros pais na área das equipes de saúde para participar da pesquisa.

Participaram dessa fase, portanto, apenas os pais que tinham filhos na faixa etária de 10 a 19 anos fora da escola, após concordar em participar e assinar o Termo de Consentimento Livre e Esclarecido - TCLE que era lido pelo pesquisador (Anexo $5)$.

Após realizar a pesquisa com os pais, o pesquisador solicitava o seu consentimento para que o adolescente também participasse da pesquisa. Com o consentimento do pai, forneciam-se informações da pesquisa ao adolescente e este era convidado a participar após a leitura do Termo de Responsabilidade do Pesquisador. Salientamos que o adolescente só participava da pesquisa se concordasse e após consentimento do seu responsável (Anexo 6).

\section{Fase 4 - Pesquisa com profissionais dos serviços de saúde}

Para identificar e analisar as construções sociais e as percepções dos profissionais de saúde, foi utilizado um formulário semi-estruturado com questões abertas e fechadas (ANEXO 7 e 8 ).

Após autorização para realização da pesquisa pela Coordenadoria de Saúde da Região Sul e pelos Supervisores Técnicos de Saúde, era feito contato com os Coordenadores das Unidades de Saúde das regiões de estudo, convidando-os para participar do estudo.

Fase 5 - Pesquisa Escolar - Entrevistas com profissionais da área de Educação Coordenadores Pedagógicos e Diretores das Escolas e jovens estudantes (Anexo 9 e 10)

Etapa I - Participaram desta fase da pesquisa Coordenadores Pedagógicos ou Diretores das escolas Municipais de Ensino Fundamental - EMEFS e das Escolas Estaduais de Ensino Fundamental e Médio das duas regiões de Estudos. 
As listas das escolas municipais localizadas nos dois Distritos foram obtidas junto às Coordenadorias de Educação Campo Limpo - Diretorias de Ensino SUL II, e Coordenadoria da Educação da Capela do Socorro - Diretorias de Ensino Sul III, da Secretaria Municipal de Educação de São Paulo mediante solicitação de autorização aos Coordenadores para realização da pesquisa.

As listas das escolas estaduais foram obtidas junto à Coordenadoria de Ensino da Região Metropolitana da Grande São Paulo - COGESP da Secretaria de Estado da Educação - Governo do Estado de São Paulo mediante autorização sob Protocolo: 159/0374/2007.

A solicitação para realização da pesquisa à COGESP foi requerida pela pesquisadora em 13 de julho de 2007, e a autorização foi obtida em18 de outubro de 2007, sendo que, no início do ano de 2008, foram necessários novos contatos com a COGESP e Diretoria de Ensino Sul III, para atualizar a autorização obtida.

Embora autorizada a realização da pesquisa junto às escolas da rede estadual, na região do Jardim Ângela, muitas escolas diziam não ter conhecimento da autorização, sendo necessários contatos constantes com a Diretoria de Ensino Sul III e encaminhamentos das autorizações; mesmo assim, muitas escolas se recusaram a participar da pesquisa.

No trabalho de campo foram identificadas, no Distrito do Jardim Ângela, um total de 34 escolas estaduais, sendo nove Escolas Municipais de Ensino Fundamental -EMEFs, e, no Distrito do Grajaú, 52 escolas estaduais, sendo cinco EMEFS. Participaram do estudo no Jardim Ângela 24 escolas, e no Grajaú 46 escolas.

\section{Etapa II - Entrevista com jovens estudantes}

Para realizar as entrevistas com os jovens estudantes, o critério adotado foi identificar escolas com o ensino fundamental e médio na área de abrangência ou próximas das Unidades de Saúde selecionadas. O coordenador da Unidade informava quais eram as escolas localizadas na sua área de abrangência ou próximas. A partir da informação recebida, foram feitos os contatos com os Diretores das Escolas, solicitando autorização para realização da pesquisa junto aos estudantes. Embora definido esse critério de participação das escolas na área de abrangência ou próxima às Unidades de Saúde, não foi possível cumprir, pois a escola selecionada podia 
recusar-se a participar da pesquisa, ou não ter o ensino fundamental e médio previamente estabelecidos, sendo necessário identificar outras escolas.

Foram selecionadas as $5^{\mathrm{a}}$. e $7^{\mathrm{a}}$ séries do ensino fundamental e a $1^{\mathrm{a}}$ e $2^{\mathrm{a}}$ séries do ensino médio. Podendo participar do estudo apenas os jovens na faixa etária de 10 a 19 anos, sendo necessário o consentimento dos pais ou responsáveis.

Participaram da pesquisa os alunos das escolas estaduais Jardim Moraes Prado II e Levi Carneiro, no Distrito do Grajaú e das escolas José Lins do Rego e Dra. Rosa Pavone Pimont.

Os pesquisadores visitavam as escolas selecionadas e, com os coordenadores pedagógicos, selecionavam as salas de aula. Os alunos eram convidados a participar da pesquisa, após a explicação dos objetivos do estudo e de todas as informações necessárias. Os jovens que se interessavam levavam os TCLEs para conhecimento e assinatura dos pais ou responsáveis (Anexo 11). Os pesquisadores retornavam à escola depois de dois dias para recolher os TCLEs e realizar a coleta dos dados. Muitas dificuldades foram encontradas, pois os alunos esqueciam os TCLEs e no período programado para a coleta das informações houve várias ocorrências, tais como greves, provas, avaliações realizadas pelo Sistema de Avaliação de Rendimento Escolar do Estado de São Paulo -SARESP, da Secretaria da Educação do Estado de São Paulo - SEE/SP, trabalhos pedagógicos, que não permitiram realizar as entrevistas no período planejado.

\section{Fase 6 - Entrevista com os subprefeitos, ONG Sou da Paz e Sociedade Santos Mártires e participação no Comitê Intersetorial da Capela do Socorro}

Etapa I - Para conhecer as políticas públicas para os jovens existentes na região foram realizadas entrevistas com os subprefeitos de M`Boi Mirim e Grajaú, ONG Instituto Sou da Paz e liderança da Sociedade Santos Mártires (Anexo 12).

O Instituto Sou da Paz é responsável pelo Projeto São Paulo em Paz e pela elaboração do Plano Local de Prevenção da Violência e Promoção da Convivência na região do Grajaú.

A Sociedade Santos Mártires que atua na região do Jardim Ângela desde 1987 e desempenha importante papel na articulação e desenvolvimento de ações para enfrentamento da violência na região. 
Etapa II - A pesquisadora participou do Comitê Intersetorial da Subprefeitura da Capela do Socorro, acompanhando a elaboração e consolidação do Plano Local de Prevenção da Violência e Promoção da Convivência na região do Grajaú.

No Quadro 1 estão esquematizadas as fases deste estudo. Cada fase está apresentada em conjunto com suas respectivas técnicas de coleta de dados, a natureza dos dados coletados, os instrumentos utilizados para a coleta, as fontes de informação das quais os dados foram obtidos e os métodos de análise dos dados. 
Quadro 1: Metodologia - Coleta de dados

\begin{tabular}{|c|c|c|c|c|c|}
\hline Fases & Objetivos & $\begin{array}{c}\text { Técnicas de } \\
\text { coleta de } \\
\text { dados }\end{array}$ & $\begin{array}{l}\text { Natureza } \\
\text { dos dados } \\
\text { coletados }\end{array}$ & $\begin{array}{c}\text { Fontes de } \\
\text { informação }\end{array}$ & $\begin{array}{c}\text { Método de } \\
\text { Análise } \\
\text { dos Dados }\end{array}$ \\
\hline $\begin{array}{l}\text { Fase } \\
\text { exploratória }\end{array}$ & $\begin{array}{l}\text { Identificar } \\
\text { Entidades }\end{array}$ & $\begin{array}{c}\text { Entrevista } \\
\text { por telefone }\end{array}$ & $\begin{array}{c}\text { Quantitativos } \\
\text { e } \\
\text { Qualitativos }\end{array}$ & $\begin{array}{c}\text { Subprefeituras } \\
\text { Supervisões de } \\
\text { Saúde e } \\
\text { entidades }\end{array}$ & $\begin{array}{l}\text { Sistemati- } \\
\text { zação }\end{array}$ \\
\hline Fase I & $\begin{array}{c}\text { Caracterizar as } \\
\text { regiões } \\
\text { e identificar o } \\
\text { acesso dos jovens } \\
\text { a bens e serviços }\end{array}$ & Documental & Quantitativos & $\begin{array}{c}\text { IBGE, Fundação } \\
\text { SEADE, } \\
\text { Secretarias de } \\
\text { Governo } \\
\text { Subprefeituras } \\
\text { Supervisões e } \\
\text { Saúde }\end{array}$ & $\begin{array}{l}\text { Análise } \\
\text { documental }\end{array}$ \\
\hline $\begin{array}{l}\text { Fase II - } \\
\text { Entidades }\end{array}$ & $\begin{array}{c}\text { 1.Conhecer os } \\
\text { projetos/programas } \\
\text { e ações } \\
\text { 2.Conhecer as } \\
\text { opiniões sobre o } \\
\text { bairro. } \\
\text { 3.Conhecer as } \\
\text { opiniões sobre os } \\
\text { jovens. } \\
\text { 4..Sentidos de Ser } \\
\text { jovem }\end{array}$ & $\begin{array}{l}\text { Entrevista } \\
\text { semi- } \\
\text { estruturada }\end{array}$ & $\begin{array}{l}\text { Quantitativos } \\
\text { e qualitativos }\end{array}$ & $\begin{array}{c}\text { Entidades, } \\
\text { escolas, } \\
\text { Unidades de } \\
\text { Saúde e } \\
\text { Subprefeituras }\end{array}$ & $\begin{array}{c}\text { Análise de } \\
\text { conteúdo } \\
\text { Criação de } \\
\text { categorias } \\
\text { temáticas } \\
\text { com o } \\
\text { auxílio do } \\
\text { software } \\
\text { Sphinx } \\
\text { gerando } \\
\text { gráficos e } \\
\text { freqüências }\end{array}$ \\
\hline
\end{tabular}




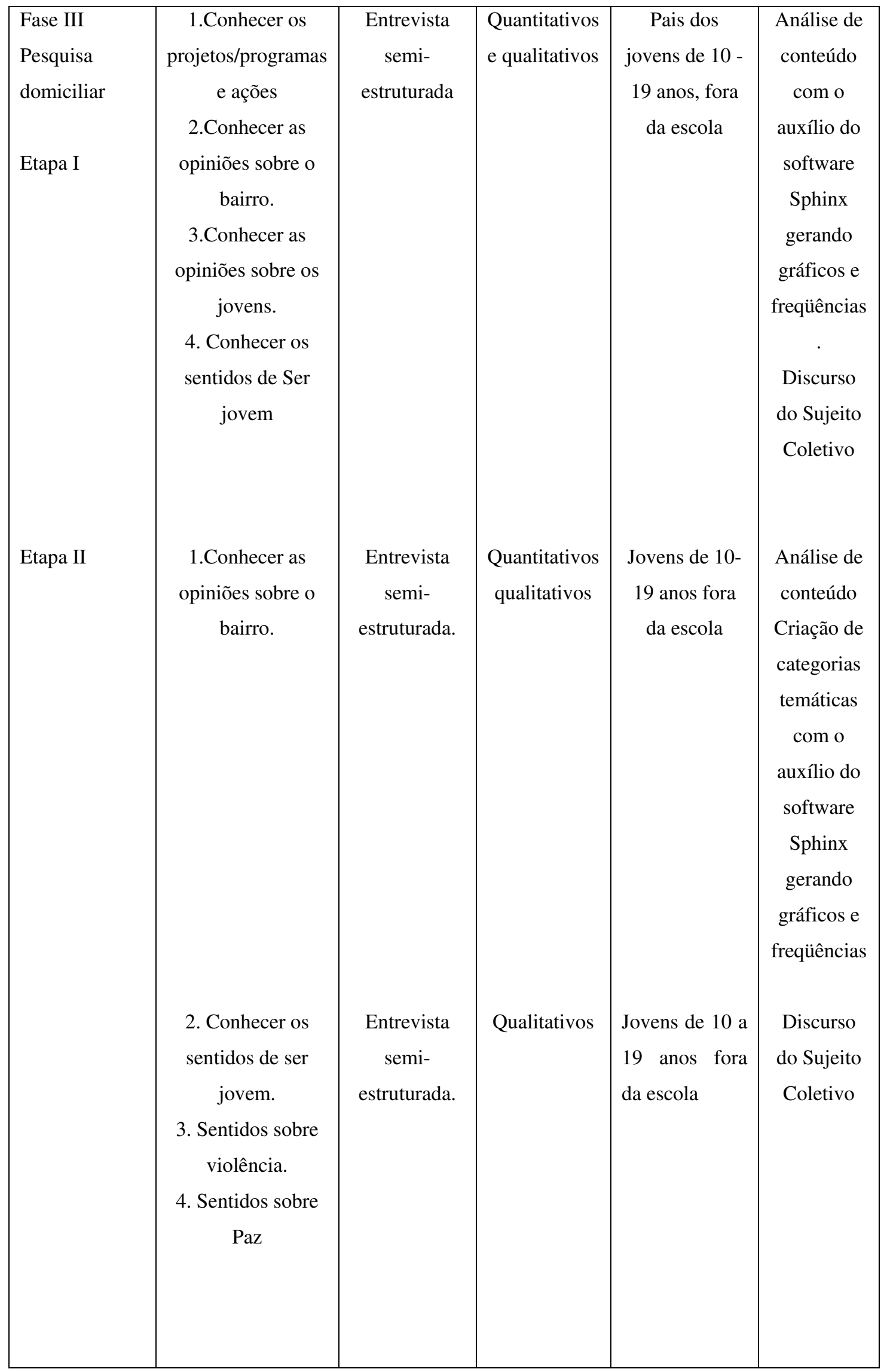




\begin{tabular}{|c|c|c|c|c|c|}
\hline $\begin{array}{l}\text { Fase IV } \\
\text { Pesquisa com } \\
\text { profissionais } \\
\text { de Saúde }\end{array}$ & $\begin{array}{c}\text { 1.Conhecer os } \\
\text { projetos/programas } \\
\text { e ações } \\
\text { 2.Conhecer as } \\
\text { opiniões sobre o } \\
\text { bairro. } \\
\text { 3.Conhecer as } \\
\text { opiniões sobre os } \\
\text { jovens. } \\
\text { 4. Conhecer os } \\
\text { sentidos de Ser } \\
\text { jovem. }\end{array}$ & $\begin{array}{l}\text { Entrevista } \\
\text { semi- } \\
\text { estruturada }\end{array}$ & $\begin{array}{l}\text { Quantitativos } \\
\text { e qualitativos }\end{array}$ & $\begin{array}{c}\text { Coordenadores } \\
\text { das Unidades de } \\
\text { Saúde com } \\
\text { Programa Saúde } \\
\text { da Família }\end{array}$ & $\begin{array}{c}\text { Análise de } \\
\text { conteúdo } \\
\text { com o } \\
\text { auxílio do } \\
\text { software } \\
\text { Sphinx } \\
\text { gerando } \\
\text { categorias } \\
\text { temáticas, } \\
\text { gráficos e } \\
\text { frequiências } \\
\text { · } \\
\text { Discurso } \\
\text { do Sujeito } \\
\text { Coletivo }\end{array}$ \\
\hline $\begin{array}{l}\text { Fase V } \\
\text { Pesquisa } \\
\text { escolar } \\
\text { Etapa I }\end{array}$ & $\begin{array}{l}\text { 1. Conhecer os } \\
\text { projetos/programas } \\
\text { e ações } \\
\text { 2. Conhecer as } \\
\text { opiniões sobre o } \\
\text { bairro. } \\
\text { 3. Conhecer as } \\
\text { opiniões sobre os } \\
\text { jovens. } \\
\text { 4. Conhecer os } \\
\text { sentidos de Ser } \\
\text { jovem }\end{array}$ & $\begin{array}{l}\text { Entrevista } \\
\text { semi- } \\
\text { estruturada }\end{array}$ & $\begin{array}{l}\text { Quantitativos } \\
\text { e qualitativos }\end{array}$ & $\begin{array}{c}\text { Coordenadores } \\
\text { pedagógicos e } \\
\text { diretores das } \\
\text { escolas } \\
\text { municipais e } \\
\text { estaduais. }\end{array}$ & $\begin{array}{c}\text { Análise de } \\
\text { conteúdo } \\
\text { Criação de } \\
\text { categorias } \\
\text { temáticas } \\
\text { com o } \\
\text { auxílio do } \\
\text { software } \\
\text { Sphinx. } \\
\text { gerando } \\
\text { gráficos e } \\
\text { freqüências } \\
\text {. } \\
\text { Discurso } \\
\text { do Sujeito } \\
\text { Coletivo }\end{array}$ \\
\hline
\end{tabular}




\begin{tabular}{|c|c|c|c|c|c|}
\hline Etapa II & $\begin{array}{l}\text { 1. Conhecer as } \\
\text { opiniões sobre o } \\
\text { bairro. } \\
\text { 2.Conhecer os } \\
\text { sentidos de ser } \\
\text { jovem. } \\
\text { 3. Sentidos sobre } \\
\text { violência. } \\
\text { 4. Sentidos sobre } \\
\text { Paz }\end{array}$ & $\begin{array}{l}\text { Entrevista } \\
\text { semi- } \\
\text { estruturada }\end{array}$ & $\begin{array}{l}\text { Quantitativos } \\
\text { quantitativos }\end{array}$ & $\begin{array}{l}\text { Jovens de } 10 \text { a } \\
19 \text { anos. }\end{array}$ & $\begin{array}{c}\text { Análise de } \\
\text { conteúdo. } \\
\text { Criação de } \\
\text { categorias } \\
\text { temáticas } \\
\text { com o } \\
\text { auxílio do } \\
\text { software } \\
\text { Sphinx. } \\
\text { gerando } \\
\text { gráficos e } \\
\text { frequiências } \\
\text {. } \\
\text { Software } \\
\text { Discurso } \\
\text { do Sujeito } \\
\text { Coletivo }\end{array}$ \\
\hline \multirow[t]{2}{*}{$\begin{array}{l}\text { Fase VI } \\
\text { Pesquisa com } \\
\text { os gestores das } \\
\text { subprefeituras } \\
\text { e } \\
\text { lideranças/ONG }\end{array}$} & $\begin{array}{c}\text { Conhecer as } \\
\text { políticas públicas } \\
\text { destinadas aos } \\
\text { jovens. }\end{array}$ & Entrevista & Qualitativos & $\begin{array}{c}\text { Subprefeitos } \\
\text { ONG Sou da } \\
\text { paz } \\
\text { e Sociedade } \\
\text { Santos } \\
\text { Mártires }\end{array}$ & $\begin{array}{c}\text { Práticas } \\
\text { discursivas }\end{array}$ \\
\hline & $\begin{array}{l}\text { Acompanhar } \\
\text { elaboração do } \\
\text { plano de } \\
\text { intervenção }\end{array}$ & $\begin{array}{l}\text { Observação } \\
\text { participante }\end{array}$ & Qualitativos & $\begin{array}{c}\text { Comitê } \\
\text { Intersetorial }\end{array}$ & $\begin{array}{c}\text { Práticas } \\
\text { Discursivas } \\
\text {. }\end{array}$ \\
\hline
\end{tabular}




\subsection{ASPECTOS ÉTICOS DA PESQUISA}

$\mathrm{Na}$ pesquisa foram observados os cuidados éticos essenciais: os consentimentos informados, a proteção do anonimato e o resguardo do uso abusivo do poder na relação entre pesquisador e participante (SPINK,1997).

Para cada entrevistado foi explicado claramente o objetivo da pesquisa e solicitada a permissão para a realização das entrevistas. A pesquisa envolveu jovens de idade de 10 a 19 anos, portanto foi necessária a autorização do responsável legal e obtenção de sua assinatura no Termo de Consentimento Livre e Esclarecido. Além da autorização do responsável, foi também solicitado o consentimento do jovem. Esclarecemos que o jovem teve o direito de recusar-se a participar da pesquisa, mesmo com o consentimento e autorização dos pais ou responsáveis para a participação.

O projeto de pesquisa foi encaminhado e aprovado pelo Comitê de Ética da Faculdade de Saúde Pública da Universidade de São Paulo - COEP/FSP -USP, de acordo com a Resolução CNS 196/96, protocolo No 1489, OF.COEP/276/06 e Comitê de Ética e Pesquisa da Secretaria Municipal de Saúde de São Paulo, protocolo de pesquisa CAAE - 00015/06, e parecer No 0042/2006 - CEP - SMS (Anexo 13).

\subsection{ANÁLISE DOS DADOS}

A análise dos dados nas diferentes fases da pesquisa se diferenciou de acordo com a natureza dos dados coletados. Os dados quantitativos obtidos através da aplicação dos formulários foram em parte quantificados e analisados quantitativamente, e em parte analisados qualitativamente, por meio da análise do conteúdo e do Discurso do Sujeito Coletivo.

Para análise dos dados das diferentes fases da pesquisa, utilizamos a de interpretação de sentidos, sugerida por MINAYO (2002, 2004, 2005). A proposta, segundo a autora, "é um caminho de análise de significados dentro de uma perspectiva das correntes compreensivas das ciências sociais que analisa: (a) as 
palavras; (b) as ações; (c) conjunto de inter-relações; (d) grupos; (e) instituições; (f) conjunturas, dentre outros campos analíticos"( MINAYO, 2005, p.202).

A interpretação dos sentidos proposta por (MINAYO, 2005) tem base em uma perspectiva socioantropológica e tem como foco o fenômeno cultural. Devido à existência de várias concepções e teorias sobre esse, tema MINAYO adota o conceito de GEERTZ (1979), que concebe o ser humano como "um animal amarrado a teias de significados que ele mesmo teceu". GEERTZ (1979) considera a cultura como intricadas teias e a sua interpretação pelos que a vivem e ao mesmo tempo produzem estruturas de significados socialmente estabelecidos. "A interpretação seria, portanto, a compreensão dessas estruturas, dentro de sua base social material. A dialética entre as interpretações e reinterpretações dos diferentes atores sociais que interagem dentro das condições objetivas em determinado espaço e tempo é a contextualização" (GEERTZ,1979).

Para a comparação dos dados entre os dois distritos utilizou-se o software Sphinx plus Versão 4.0, e para a elaboração dos Discursos do Sujeito Coletivo o QualiQuantisoft, versão 1.3c- build (2), desenvolvido por Spi-Sales \& Paschoal Informática.

Inicialmente os dados quantitativos foram trabalhados em forma de tabelas e gráficos, incluindo análise univariada e bivariada com descrição absoluta e percentual, cruzamento de variáveis e análise de correspondência (PEREIRA, 2004).Quanto aos testes estatísticos utilizados, foram sempre de Qui-Quadrado em razão das tabelas de contingência, com vistas a identificar possíveis associações entre as variáveis estudadas. $\mathrm{O}$ teste de comparação entre a diferença de duas proporções obtidas de amostras independentes (alunos na escola e alunos que não freqüentam a escola) considerou uma margem de erro de 5\% (nível de confiança de 95\%). A rejeição da Hipótese nula - HO baseou-se no intervalo de confiança e no teste Z, para o qual é atribuído um valor P. Os cálculos foram realizados pelo programa Direccion Xeral de Saúde Pública Version 3.1 (2006).

Os programas utilizados para análise do conteúdo foi o Sphinx plus Versão 4.0 e para produção dos mapas foi o Mapinfo Versão 7.0 da Mapinfo co (2002). 
A análise dos dados foi organizada em seis fases:

Fase I - Cenário da Pesquisa.

Fase II - Análise dos Projetos/Programas e Ações das Entidades, das Escolas e das Unidades de Saúde.

Fase III - Análise das regiões de estudo por meio das opiniões das lideranças, profissionais de saúde, educadores, pais e jovens.

Fase IV - Informações sobre os jovens obtidas por meio das entrevistas, com entidades, profissionais de saúde, educadores e pais.

Fase V - Sentidos de ser jovem obtidos nas entrevistas com entidades, profissionais de saúde educadores e pais.

Fase VI - Sentidos de ser jovem, sobre violência e paz, dos jovens das regiões de estudo.

Os dados qualitativos das Fases II, III, e IV,V e VI do formulário utilizado na pesquisa coletados junto às entidades, escolas, subprefeituras, pais, profissionais de saúde, educadores e jovens foram categorizados e apresentados em forma de tabelas, listagens e narrativas temáticas.

Para a realização da análise da Fase II referente aos projetos, programas ou ações existentes nas áreas dos distritos destinados aos jovens da faixa etária de 10-19 anos, tomamos base no estudo Escolas Inovadoras: experiências bem sucedidas em escolas públicas (ABRAMOVAY, et al, 2003). Na análise identificamos oito grandes temas, isto é, os mais recorrentes dentre o material coletado, quais sejam: área educacional, área cultural, área ambiental, área da saúde, área de esporte e lazer, área profissionalizante, desenvolvimento psicossocial e participação, comunicação e cidadania, a partir da leitura dos objetivos e das descrições do projeto e ações desenvolvidas pelas entidades, instituições e serviços nas regiões, categorizamos os projetos e as ações.

Para classificar as entidades responsáveis pelos projetos desenvolvidos nas duas regiões de estudo para os jovens, utilizamos a Tipologia dos Atores da Sociedade Civil, desenvolvida por LAVALLE, CASTELLO e BICHIR (2006). Segundo os autores, o estudo das organizações civis impõe o desafio de desenvolver caracterizações capazes de organizar de modo coerente a complexidade e diversidade inerente a esses atores: 
os rótulos normalmente utilizados para distinguir atores societários são objetos de disputa simbólica para atribuir sentido ao seu agir, e, portanto a assunção de uma determinada denominação por parte das entidades entrevistadas, obedece a uma série de cálculos de auto-representação pública, destinados a posicioná-las em campos específicos do mundo das organizações civis perante interlocutores determinados (LAVALLE, CASTELLO e BICHIR, 2006, p .9).

Visando contornar essa dificuldade, LAVALLE et al. (2006) não classificam as organizações civis com base em suas autodefinições, e sim conforme critérios objetivos de duas ordens: público para qual os projetos são destinados e estratégia:

1. O conjunto de beneficiários encarna uma unidade real ou abstrata, exemplos: moradores do bairro ou cidadãos, respectivamente, cujos componentes são indivíduos e atores coletivos, ou segmentos da população concebidos como membros ou sócios, como público alvo, ou como a comunidade.

2. A cada tipo de associação corresponde uma estratégia de atuação distintiva e combinações excludentes de atividades orientadas para a reivindicação e mobilização, para o fornecimento de serviços, para a organização popular, ou para a intermediação entre o governo e os beneficiários (p. 9-10).

Portanto, com base nesses critérios, os autores delinearam uma tipologia de atores da sociedade civil denominadas ONGs, organizações populares, associações de bairro, associações comunitárias, entidades assistenciais, articuladoras e fóruns, que utilizamos para classificar a entidades existentes nos dois distritos administrativos.

A análise dos dados da Fase $\mathbf{V}$, cujo objetivo foi identificar os sentidos de ser jovem, para as lideranças, pais, profissionais de saúde e educadores, e da Fase VI, que visou identificar os sentidos de ser jovem, sentidos da violência e da paz dos jovens estudantes e não estudantes, foi realizada através da Técnica do Discurso do Sujeito Coletivo - DSC, desenvolvida por LEFÈVRE e LEFÈVRE (2000).

A técnica do DSC foi estruturada para ser trabalhada a partir de entrevistas individuais com questões abertas. Adaptamos a técnica utilizando-a em algumas respostas de questões abertas obtidas por meio dos formulários . 
Para a elaboração do Discurso do Sujeito Coletivo, utiliza-se quatro figuras metodológicas: expressões-chaves, idéias centrais, ancoragem e o discurso do Sujeito Coletivo (LEFEVRE e LEFEVRE,2003).

As expressões chaves (ECH), são trechos ou transcrições literais do discurso destacadas pelo pesquisador e que revelam a essência do depoimento, ou seja, o conteúdo discursivo dos segmentos em que se divide o depoimento, e corresponde geralmente às questões da pesquisa.

As idéias centrais (IC) são um nome ou expressão lingüística que revela e descreve, da maneira mais sintética e fidedigna possível, o sentido de cada um dos discursos analisados e de cada conjunto homogêneo de $\mathrm{ECH}$, que vai dar origem, posteriormente, ao DSC.

Ancoragem (AC) é uma figura metodológica inspirada na teoria da representação social e consiste na manifestação lingüística explícita de uma dada teoria, ou ideologia, ou crença, presente no discurso.

O Discurso do Sujeito Coletivo (DSC) é a principal da figura metodológica. "É uma estratégia metodológica com vistas a tornar mais clara uma dada representação social e o conjunto das representações que conforma um dado imaginário" (LEFÈVRE ; LEFÈVRE e TEXEIRA, 2000, p.20).

Para construir o DSC, parte-se dos discursos a que são submetidos inicialmente, a um trabalho analítico de decomposição que, consiste basicamente, "na seleção das principais ancoragens e/ou idéias centrais presentes em cada um dos discursos individuais e em todos eles reunidos, e que termina sob uma forma sintética, onde se busca a reconstituição discursiva da representação social" (LEFÈVRE; LEFÈVRE, e TEIXEIRA, 2003, p. 20). É como se uma só pessoa falasse por um conjunto de pessoas mas, obviamente, trata-se de uma construção artificial.

Os dados coletados, nas diferentes fases dessa investigação, foram analisados pela triangulação metodológica (PATTON, 1987). No contexto da pesquisa social, esse tipo de abordagem tem sido usual quando múltiplos métodos de pesquisa são empregados para analisar um problema. A utilização de multimeios, própria da proposta de triangulação, garante uma maior validade de dados, ou seja, a operacionalização de vários métodos. Esta estratégia metodológica parte da 
constatação de que as ações sociais e falas dos atores devam ser contextualizadas a fim de esclarecer e aprofundar os aspectos da realidade. A validação dos dados não é realizada por meio de aferição de índices e dados, ou do somatório de dados qualitativos e quantitativos, ao contrário, trata-se de uma analise das relações de contexto com as ações (PATTON 1987, ADORNO e CASTRO 1994). 


\section{RESULTADOS E DISCUSSÃO}




\title{
12. RESULTADOS E DISCUSSÃO
}

\begin{abstract}
A consciência das diferenças, embutidas no cotidiano de nossa experiência da cidade, marca profundamente a subjetividade. Dependendo do lugar social de onde é visto, o teatro e a condução permitem, pelo menos, duas leituras diferentes; a dos filhos da luz e a dos filhos da sombra. O que poderá aproximá-las? Há uma troca constante de olhares, mas a reciprocidade deles está carregada de significados diferentes.
\end{abstract}

\section{Sílvia Mello}

Este estudo teve como objetivo analisar e comparar os processos que orientam as ações coletivas e as experiências participativas de promoção da saúde dos jovens, realizadas pelas organizações governamentais e não-governamentais para o enfrentamento e resistência à violência nos Distritos Administrativos do Grajaú e Jardim Ângela do município de São Paulo, visando contribuir para a construção de uma cultura de paz e implementação de políticas públicas para a juventude local.

A primeira parte da pesquisa concentrou-se na construção dos referenciais teóricos e da metodologia. A segunda parte foi a realização da pesquisa empírica

Nesta parte do estudo apresentamos os resultados obtidos no trabalho empírico sobre o território, a experiência dos jovens no seu cotidiano a partir das percepções dos jovens, pais dos jovens que deixaram de freqüentar a escola, lideranças, educadores, profissionais de saúde e gestores. 


\subsection{OS JOVENS SUAS FAMÍLIAS E A COMUNIDADE}

Os resultados analisados neste capitulo referem-se aos dados coletados por meio de entrevistas com os jovens estudantes e não estudantes dos distritos de estudo.

O objetivo dessa fase do estudo foi caracterizar os jovens e suas famílias, bem como outros atores envolvidos com os mesmos territórios, e analisar as construções sociais e as percepções sobre o que é ser jovem, as condições de vida dos jovens e de suas famílias - e a relação com a violência. Junto aos jovens identificamos ainda as percepções sobre violência e paz.

Neste capítulo vamos tratar primeiramente dos jovens que estão indo à escola e depois dos que deixaram de freqüentá-la para identificar possíveis diferenças entre os dois grupos em relação às condições de vulnerabilidade à violência.

\subsubsection{Conhecendo os jovens estudantes}

Participaram da pesquisa os jovens das $5^{\mathrm{a}}$. e $7^{\mathrm{a}}$. séries do ensino fundamental e das $1^{\mathrm{a}}$. e $2^{\mathrm{a}}$ séries do ensino médio das escolas estaduais Jardim Moraes Prado II e Levi Carneiro do Distrito do Grajaú e das escolas José Lins do Rego e Dra. Rosa Pavone Pimont do DA Jardim Ângela, situadas nas áreas consideradas de maior vulnerabilidade social, segundo o Centro de Estudos da Metrópole. Foram entrevistados,nos dois distritos de estudo, 463 jovens que freqüentam a escola, sendo $316(68,3 \%)$ no DA do Grajaú e 147 (31,7\%) no DA do Jardim Ângela.

Quanto à idade de todos os jovens entrevistados nas duas regiões de estudo, verifica-se que 52,7\% tinham menos de 15 anos e 44,1\%, 15 anos ou mais. Analisando os percentuais por idade, observamos que entre os jovens estudantes não houve diferenças significativas entre os menores de 15 anos e os de 15 a 19 anos, (Anexo 13). 
Quanto à escolaridade dos jovens estudantes entrevistados, 37,4\% cursavam o ensino médio e $26,8 \%$, o ensino fundamental nos distritos, conforme tabela 2.

Tabela 2- Nível de ensino dos jovens que freqüentam a escola - DA Grajaú e Jardim Ângela - São Paulo, 2008

\begin{tabular}{|c|c|c|c|}
\hline \multirow{2}{*}{ Nível de ensino } & \multicolumn{2}{|c|}{ Distrito } & \multirow[b]{2}{*}{ Total } \\
\hline & Grajaú & Jardim Ângela & \\
\hline Ensino fundamental 5a . Série & 26,9 & 26,5 & 26,8 \\
\hline Ensino fundamental 7a․ Série & 24,7 & 24,5 & 24,6 \\
\hline Ensino médio 1 a Série & 42,1 & 27,2 & 37,4 \\
\hline Ensino fundamental $2^{\mathrm{a}}$. série & 6,3 & 21,8 & 11,2 \\
\hline Total & 100 & 100 & 100 \\
\hline
\end{tabular}

A maior proporção dos jovens nos distritos de estudo mora com o pai e a mãe, como mostra a Tabela 3, não havendo diferenças significativas entre os dois distritos. Na categoria Outros, incluem-se irmãos, avós e tios.

Tabela 3- Com quem os jovens que frequientam a escola moram - DA Grajaú e Jardim Ângela -São Paulo, 2008

\begin{tabular}{lcrrrr}
\multicolumn{1}{c}{ Distritos } & Pai e Mãe & Mãe & Pai & Outros & Total \\
\hline Grajaú & 57,6 & 32,3 & 4,6 & 5,5 & 100 \\
Jardim & & & & & \\
Ângela & 67,4 & 22,5 & 6,1 & 4,1 & 100 \\
\hline Total & $\mathbf{6 0 , 6}$ & $\mathbf{2 9 , 3}$ & $\mathbf{5 , 1}$ & $\mathbf{5 , 1}$ & $\mathbf{1 0 0}$ \\
\hline
\end{tabular}

A maioria dos jovens entrevistados relata que gosta de morar com os pais $(98,1 \%)$, Anexo 14. Constata-se que não há diferenças de opiniões dos jovens entre distritos e as diferentes faixas etárias. Entre as razões apresentadas pelos jovens que relataram gostar de morar com os pais, destacam-se: amam os seus pais $(19,8 \%)$, consideram que eles são "legais" $(14,1 \%)$. Os jovens ainda mencionam que recebem muito amor e carinho, são felizes vivendo com a família, têm apoio da família e são unidos. Há ainda jovens que não explicam por que gostam de morar com os pais $(7,5 \%),($ Anexo- 15) . As principais razões apresentadas pelos jovens que revelam não gostar de morar com os pais foram brigas e discussões $(28,1 \%)$, (Anexo 16). 
Nos dois distritos, os jovens citam que na família gostam da união $(16,6 \%)$, do amor e carinho dos pais e familiares $(14,3 \%)$. Nos relatos pode-se identificar que os jovens atribuem importância a alegria e felicidade, compreensão, apoio e respeito, companheirismo, amizade e solidariedade, que existem no ambiente familiar. Comparando as opiniões dos jovens residentes nos dois distritos, verifica-se que não há diferenças entre os relatos dos jovens, (Anexo 17).

Os jovens, de modo geral, consideraram o relacionamento com os pais ótimo $(47,5 \%)$ e muito bom (27,2\%), (Anexo 18). Apesar disso, nas explicações para respostas, encontram-se relatos de brigas e discussões em família (Anexo 19), sugerindo existência de dificuldades de relacionamento e de brigas e discussões familiares. As respostas em ambas as tabelas não apresentaram diferenças significativas entre as faixas etárias e os distritos.

Observa-se que uma pequena proporção de jovens, sendo 40 citações em um universo de 463 jovens, considera o relacionamento com os pais regular e ruim (42,5\%). Citam que o relacionamento é difícil (42,5\%), há brigas em casa (10,0\%), com destaque para a faixa etária de 15 a 19 anos nos dois distritos. A falta de liberdade $(10,0 \%)$ é mais referida entre os jovens na faixa etária de 10 a 14 anos e no DA do Jardim Ângela (Anexo 20). Portanto os dados sugerem que, na faixa etária de 10 a 14 anos, os pais exercem um maior controle sobre os filhos, em ambos os distritos.

A maioria dos jovens gosta de conversar com os pais $(82,5, \%)$. Os jovens conversam sobre a escola $(22,9 \%)$, o próprio jovem $(14,1 \%)$, amigos e namorados $(7,3 \%)$, a família $(8,9 \%)$ e sobre outros vários assuntos. Não há diferenças entre os distritos e as diversas faixas etárias.

Em ambos os distritos, verifica-se que o tema escola é predominante nas conversas dos filhos e pais, principalmente na faixa etária de 10 a 14 anos (28,1\%), o que evidencia a importância dessa instituição na vida dos jovens da periferia e a preocupação com as dificuldades de aprendizagem, com a motivação para os estudos e com as sucessivas reprovações que podem levar ao abandono da escola.

Além do tema escola, as conversas dos jovens com seus familiares giram em torno da família e o cotidiano, sobre o próprio jovem, lazer e esporte, principalmente, futebol, sexualidade, amigos, namorados, drogas e trabalho. 
Os temas violência, drogas e sexualidade são os mais freqüentes na faixa etária de 15 a 19 anos, pois é quando os jovens se tornam mais vulneráveis às ações do tráfico. Não há diferença entre as informações obtidas com jovens dos dois distritos. (Anexo 21).

Um percentual pequeno de jovens $(14,8 \%)$ respondeu não saber explicar por que não gosta de conversar com os pais. Um percentual menor $(13,8 \%)$ mencionou que os pais não os entendem, especialmente os da faixa etária de 15 a 19 anos. Ter vergonha de falar de certos assuntos é outro motivo que explica essa dificuldade $(12,3 \%)$, juntamente com o sentimento de que não há identidade entre pais e filhos sobre determinados assuntos $(11,1 \%)$ e consideram os pais muito rígidos e antiquados $(13,1 \%)$. No Jardim Ângela, dizem ter vergonha de falar de "certos assuntos" (25,0\%).(Anexo 22)

Esses dados sugerem a existência de conflitos intergeraçõess, que refletem a dificuldade de diálogo entre os jovens e familiares, principalmente quando se trata de assuntos relacionados à sexualidade.

Sintetizando, os resultados evidenciaram que os jovens gostam dos pais e/ou familiares, o relacionamento com a família é considerado ótimo e muito bom, no entanto relatam a existência de brigas e discussões. Os temas mais presentes nas conversas entre os familiares são a escola, o jovem e o cotidiano, e a família.

- Os jovens estudantes e a escola

A maioria dos jovens entrevistados nos distritos gosta da escola $(74,7 \%)$. No DA do Jardim Ângela, há um percentual maior de jovens que relataram gostar da escola $(84,4 \%)$ do que no Grajaú $(70,3 \%)$, sendo esta diferença significativa do ponto de vista estatístico (Anexo 23).

Os principais motivos apresentados pelos jovens dos distritos que gostam da escola foram: ter amigos e colegas (19,9\%), ensino bom e de qualidade $(18,2 \%)$, aprendem muitas coisas novas $(18,2 \%)$, os professores são bons e ótimos $(17,9 \%)$, o ambiente é bom (15,3\%), (Anexo 24). 
Esses dados demonstram, portanto, que os jovens, em sua maioria, gostam da escola, valorizam a convivência com os amigos e colegas, a oportunidade de aprendizagem, a qualidade do ensino, o corpo docente e um ambiente saudável.

Os que não gostam justificam sua opinião, destacando o ambiente de "bagunça" e indisciplina $(18,8 \%)$ e a precariedade do prédio e instalações (10,3\%). A violência entre os alunos é referida por apenas $(7,7 \%)$ dos jovens da faixa etária de 10 a 14 anos (Anexo 25).

Comparando os distritos, verifica-se que um percentual maior de jovens do Grajaú $(20,2 \%)$ se desagradam com a "bagunça" e indisciplina nas escolas contra 13\% para o Jardim Ângela. No Jardim Ângela ainda há jovens que consideram a escola muito distante de suas casas $(8,7 \%)$ e que é muito rigorosa e repressora $(8,7 \%)$.

Entre as opiniões dos jovens sobre de que mais gostam e de que menos gostam na escola, destacam-se os professores (22\%), os amigos $(19,7 \%)$ e a qualidade do ensino $(15,1 \%)$. A indisciplina $(13,8 \%)$ e a merenda $(10,2 \%)$ são mencionados novamente como aspectos que desagradam os jovens (Anexo 26 e 27).

Constatou-se, portanto, que em ambas as regiões a maioria dos jovens gosta da escola. No Grajaú há maior porcentagem de jovens que gosta da escola. Em ambas as regiões os jovens valorizam os amigos, os professores e a qualidade do ensino. Os dados também demonstram que os principais aspectos negativos da escola, na opinião dos jovens, são a indisciplina, a estrutura (prédio, instalações, limpeza e higiene) e qualidade da merenda. Consideram ainda dificuldades com professores, funcionários, incluindo diretores, e a violência.

- Os jovens estudantes e a participação nos grupos da comunidade A maioria dos jovens dos distritos administrativos não participa de grupos na comunidade $(93,7 \%)$, o que indica que eles não participam das ações nem de projetos existentes nas regiões (Anexo 28).

A participação dos jovens em grupos na comunidade refere-se aos existentes na Igreja, sendo no Grajaú $(6,3 \%)$ e no Jardim Ângela $(15,4 \%)$, o que confirma a forte participação da Igreja Católica no distrito do Jardim Ângela. Verifica-se ainda a 
participação no Clube de Desbravadores da Igreja Adventista (6,3\%) em ambos distritos.

Uma pequena percentagem de jovens citou a existência de outros grupos nas regiões, sendo, no Grajaú, grupos de capoeira (6,3\%), grupo de teatro $(6,3 \%)$ entidades Girassol (6,3\%), Elos da dança (6,3\%), Escola da família (6,3\%), Centro de Educação Unificado - CEU Três Lagos (6,3\%). No Jardim Ângela, um percentual pequeno de jovens mencionou entidades e programas ofertados a eles: Agente jovem (7,7\%), Força Jovem Brasil (7,7\%), Clube da Turma $(7,7 \%)$ e grupo ecológico $(7,7 \%)$. (Anexo 29). Os percentuais indicam desconhecimento e uma pequena participação em programas e ações existentes nos distritos.

As atividades mais referidas pelos jovens como núcleos da sua participação foram mutirões de limpeza e ação comunitária nos distritos. A participação nas atividades de mutirão corresponde, no Jardim Ângela, a 23,1\% e, no Grajaú, a 6,3\%; na ação comunitária, 15,4\% no Jardim Ângela e 6,3\% no Grajaú. Os jovens da faixa etária de 10 a 14 anos participam de mutirões de limpeza, e os jovens na faixa etária de 15 a 19 das ações comunitárias em ambos os distritos, (Anexo 30).

No Jardim Ângela um pequeno percentual de jovens participa, ainda, das seguintes atividades junto às entidades: danças, conscientização sobre drogas e violência, palestras, entregas de folhetos, plantação de mudas e árvores, promoção de festas para arrecadar dinheiro e trabalhos diversos (Anexo 30).

No Grajaú, verifica-se também um pequeno percentual de jovens que participa de atividades como capoeira, dança, cinema, teatro, cursos profissionalizantes, computação, coleta de material reciclável, visita aos asilos e orfanatos, e prece pelo bairro (Anexo tabela 30).

Constata-se, pelos percentuais apresentados, que a participação dos jovens nos territórios e nos projetos das entidades é muito pequena. Quando os jovens participam de ações, estão relacionadas à ação comunitária, ligadas à Igreja, com predominância da Católica. A participação em atividades culturais nas regiões de estudo não é significativa.

Os dados sugerem que a maior porcentagem de jovens que se dedicam a atividades de ação comunitária no Jardim Ângela relaciona-se com a presença da 
Sociedade Santos Mártires, articuladora da rede de proteção aos jovens na região, conforme será visto no decorrer do estudo.

- O jovem estudante e o lazer

Nas horas de folga e lazer, os jovens ocupam o tempo com internet computador (23,8\% no Jardim Ângela e 9,5\% no Grajaú) -, jogam bola e se dedicam a atividades esportivas (22,4\% no Grajaú e 16,8\% no Jardim Ângela), estudam, dedicam-se à leitura e a desenhar (19,6\% no Grajaú e 20,4\% no Jardim Ângela), assistem a televisão e filmes (16,1\% no Grajaú e 15,6\% no Jardim Ângela). Os jovens na faixa etária de 10 a 14 anos que dizem ocupar seu tempo brincando nos dois distritos corresponde a 20,9\% (Anexo 31).

Os dados mostram que, nas horas de lazer, os jovens permanecem em casa ou ficam na rua. Na rua frequientam lan houses, jogam bola e empinam pipa. Quando estão em casa, ocupam a maior parte do tempo dormindo, brincando, ouvindo música, estudando, assistindo a filmes, jogando videogames. Na faixa etária de 15 a 19 anos (7,6\%) ocupam o tempo nas horas de folgas trabalhando no mercado informal (Anexo 31). Os dados sugerem que as meninas permanecem em casa e os meninos, quando não trabalham, ficam na rua.

\subsubsection{Conhecendo os jovens que não freqüentam mais a escola}

Desta fase da pesquisa, participaram jovens que deixaram de freqüentar a escola, selecionados nas áreas de atuação das equipes de saúde da família, também considerados territórios de maior vulnerabilidade social em ambos os distritos de estudo.

- A escolaridade e a idade dos jovens quando deixaram de freqüentar a escola

Participaram desta fase da pesquisa 77 jovens não estudantes, sendo 36 do Grajaú $(46,8 \%)$ e 41 no Jardim Ângela $(53,2 \%)$. Foram entrevistados 16 jovens na faixa etária de 10 a 14 anos (20,8\%) e 61 jovens na faixa etária de 15 a 19 anos $(79,2 \%)$. Do total de jovens entrevistados, 10 jovens (13\%) deixaram a escola 
quando cursavam o ensino médio e 67 (87\%) deixaram a escola no ensino fundamental, (Anexo 32).

No que se refere ao tempo que deixaram a escola, 36 jovens $(46,8 \%)$ estão fora da escola há menos de 1 ano, 28 jovens (36,4\%) estão fora da escola de 1 a 2 anos. O total de jovens que estão fora da escola há 3 anos ou mais é de 11 (14,3\%).

$\mathrm{O}$ fato de a maioria dos entrevistados ter abandonado a escola no ensino fundamental é um dado preocupante, principalmente se agregado à questão da idade e aos motivos pelos quais deixaram a escola.

\section{- Os jovens não estudantes e a escola}

Os jovens não estudantes relatam que gostavam da escola (72,7\%). Gostavam dos amigos e dos colegas $(55,4 \%)$, os professores eram bons e "legais" $(30,4 \%)$, o ensino era bom (14,3\%), aprendiam muitas coisas (12,5\%), a escola era "legal" $(10,7 \%)$ e gostavam do espaço da escola e do prédio (8,9\%), (Anexo 33).

Os jovens que responderam não gostar da escola apresentaram os seguintes motivos: não gostavam das aulas de matemática $(16,9 \%)$, brigas entre alunos e violência (13,0\%), não gostavam dos professores $(11,7 \%)$, não gostavam das aulas de português $(9,1 \%)$, bagunça dos colegas $(9,1 \%)$ e não gostavam da direção da escola (7,8\%), (Anexo 34).

O principal motivo referido pelos jovens para deixarem de estudar foi a perda de estímulo (27,3\%), sendo um pouco maior na faixa etária de 10 a14 anos (31,3\%) do que na faixa etária de 15 a 19 anos (26,2\%). A perda de estímulo no ensino fundamental corresponde a 28,4\% e no ensino médio a 20,0\%, (Anexo35).

O segundo motivo mais citado para os jovens deixarem a escola foi a gravidez (20,8\%), na faixa etária de 15 a 19 anos e entre as jovens do ensino médio $(40,0 \%)$. Em terceiro lugar a necessidade de mudar de bairro (19,5\%), entre os jovens que cursavam o ensino fundamental $(22,4 \%)$ e estavam há menos de 1 ano fora da escola.

Em quarto lugar foi referido o baixo aproveitamento e a reprovação $(16,9 \%)$ entre os jovens de 15 a 19 anos (19,7\%), sendo verificado o mesmo motivo no ensino fundamental $(19,4 \%)$. 
O trabalho aparece em quinto lugar (14,3\%) entre os jovens de 15 a 19 anos que deixaram a escola. Foram citados, ainda, a falta de vagas, a distância para chegar à escola e o horário ruim, muitas faltas, baixa auto-estima e vergonha, presença de drogas na escola, discussão e brigas com os professores, casamento, "bagunça" e indisciplina.

Observa-se que os jovens que não freqüentam a escola, assim como os estudantes, gostam da escola, valorizam a convivência com os amigos, a qualidade do ensino e os professores. Os aspectos negativos evidenciados referem-se à indisciplina, violência, professores e direção da escola.

O principal motivo para deixar a escola foi a perda de estímulo e motivação. Esta perda de motivação pode relacionar-se com uma gravidez não planejada, ou com a necessidade de mudar de bairro, havendo, por isso, dificuldades para encontrar vagas nas escola e de adaptação. O baixo aproveitamento e as reprovações consecutivas bem como a necessidade de trabalhar são fatores importantes que também devem ser considerados.

- Os jovens que não freqüentam a escola e sua família

A percentagem de jovens entrevistados que mora com o pai e a mãe, nos distritos administrativos, corresponde, no Grajaú, a 19,4\% e, no Jardim Ângela, a $26,8 \%$. Verifica-se maior percentagem de jovens morando só com as mães em ambos os distritos, sendo 27,9\% no Grajaú e 43,9\% no Jardim Ângela. Entre a categoria Outros, destacam-se os familiares como avós, maridos, esposas, companheiro/a e filhos, sendo maior no Grajaú (50,0\%) conforme tabela 4. Os dados sugerem que as mães desses jovens são chefes de família nas regiões e, muitas vezes, os maridos ou companheiros são vitimados pela violência nos distritos. Mostram ainda que, nessa faixa etária, há jovens com filhos, em ambos os distritos, diferindo dos jovens estudantes. 
Tabela 4 - Com quem os jovens que não freqüentam a escola moram - DA do Grajaú e Jardim Ângela - São Paulo -2008

\begin{tabular}{ccrrrr} 
Distrito & Pai e Mãe & Mãe & Pai & Outros & \multicolumn{1}{c}{ Total } \\
\hline Grajaú & 19,4 & 27,8 & 2,8 & 50,0 & 100 \\
Jardim & & & & & \\
Ângela & 26,8 & 43,9 & 7,3 & 22,0 & 100 \\
\hline Total & $\mathbf{2 3 , 4}$ & $\mathbf{3 6 , 4}$ & $\mathbf{5 , 2}$ & $\mathbf{3 5 , 1}$ & $\mathbf{1 0 0}$ \\
\hline
\end{tabular}

Os jovens revelaram que gostam de conviver com as pessoas com quem moram $(96,1 \%)$. Os principais motivos apresentados foram: o bom relacionamento que os fazem sentir-se bem $(33,8 \%)$, o fato de serem cuidados e bem tratados $(15,6 \%)$, de gostarem e amarem as pessoas com quem moram $(11,7 \%)$, de considerarem as pessoas com quem moram "legais" e de sentirem que não existem problemas entre eles $(10,4 \%)$. Não há diferença significativa quanto ao gostar das pessoas com as quais moram entre as faixas etárias e as escolaridades do ensino fundamental e médio nos dois distritos administrativos (Anexo 36).

Os jovens consideram o relacionamento com as pessoas com quem moram como bom $(41,6)$. Os motivos apresentados foram: a conversa é boa $(22,5 \%)$, eles são compreensivos $(16,9 \%)$, são "legais" e se dão bem $(16,9 \%)$ e que não há brigas nem discussão $(14,1 \%$ ), (Anexo 37 ). Os jovens que classificaram como ruim ou regular justificaram que há brigas $(50,0 \%)$, não têm liberdade $(33,3 \%)$, falam muito de igrejas $(16,7 \%)$ e que os familiares são muito controladores $(16,7 \%)$.

Quanto ao que mais gosta na família, os jovens citaram a união $(19,5 \%)$ e o carinho que recebem $(10,4 \%)$, a convivência $(9,1 \%)$ e gostam do pai e da mãe $(9,1 \%)$ .Os jovens não gostam das brigas nem discussões (32,5\%) (Anexo 38) .

Os jovens fora da escola entrevistados gostam de conversar com os familiares $(77,9 \%)$ - (Anexo 39) e entre os assuntos de que mais gostam de conversar destacamse: escola $(38,3 \%)$, embora não estejam mais estudando, o que pode indicar a preocupação dos pais com os estudos dos filhos. Mencionaram como assunto das conversas o trabalho $(28,3 \%)$, amizades $(28,3 \%$,) questões de família $(28,3 \%)$, questões do dia a dia - cotidiano $(20,0 \%)$ e relacionamentos e/ou namoros $(20,0 \%)$ (Anexo 40). 
Os motivos apresentados pelos jovens que não gostam de conversar com os pais/familiares foram: não têm diálogo $(29,4 \%)$, há discussão e briga $(23,5 \%)$, não se sentem a vontade e têm vergonha (17,6\%) - (Anexo 41).

Os dados permitem constatar que a maioria dos jovens que não freqüentam a escola mora com os pais. Nesse grupo há jovens que moram com o marido ou companheiro e também têm filhos, mesmo na faixa etária de 10 a 14 anos, diferentemente dos jovens estudantes.

O relacionamento com os familiares é considerado bom, e os temas de conversa referem-se em primeiro lugar à escola, em segundo ao trabalho, em terceiro às amizades, em quarto à família. Os dados sugerem a preocupação dos familiares com o futuro dos jovens, atribuindo grande importância para a escola, trabalho e a família para os seus projetos de vida. Evidenciam também que os familiares preocupam-se com a influência das amizades e estas podem influir nas escolhas que farão nesse momento da vida.

- Os jovens que não freqüentam a escola e o trabalho

No que se refere ao trabalho, uma pequena proporção dos jovens entrevistados está trabalhando $(11,7 \%)$, com proporções semelhantes para as faixas etária de 10 a 14 anos $(12,5 \%)$ e de 15 a 19 anos (11,5\%).

Os jovens exercem atividades que não exigem qualificação profissional, entre elas: ajudante em mercado $(22,2 \%)$, ajudante de pedreiro $(22,2 \%)$, bico no bar $(11,1 \%)$, balconista de padaria $(11,1 \%)$, entregador $(11,1 \%)$, segurança $(11,1 \%)$ e babá $(11,1 \%)$. Verifica-se que jovens de 10 a 14 anos fazem bico em bar e trabalham como entregadores (Anexo Tabela 42).

- Os Jovens que não freqüentam a escola e o lazer

As atividades de lazer referidas pelos jovens foram: arrumar a casa e cozinhar $(49,9 \%)$, assistir a televisão e ouvir "um som" $(32,5 \%)$, ficar na rua $(24,7 \%)$, jogar bola $(23,4 \%)$, visitar amigos e parentes $(22,1 \%)$, cuidar dos sobrinhos e dos filhos (20,8\%), conversar com os amigos $(11,7 \%)$, dormir (10,4\%), empinar pipa e andar de bicicleta $(10,4 \%)$, e ajudar em casa $(7,8 \%)$. Constata-se que os jovens consideram 
como lazer realizar trabalhos domésticos, cuidar dos sobrinhos e dos filhos, trabalhar no farol, fazer bicos e ficar na "boca-de-fumo" (Anexo 43).

Os dados indicam que a maioria das jovens entrevistadas que não estudam cuida da casa, dos filhos e sobrinhos, e os homens ocupam o tempo na rua, jogando bola, empinando pipa ou andando de bicicleta. Quando não estão cuidando dos afazeres domésticos ou na rua, dormem, assistem a televisão ou ouvem música. A ociosidade e a vivência na rua evidencia que os jovens do sexo masculino são vítimas potenciais de homicídios e estão mais vulneráveis ao consumo de drogas e ao tráfico nas regiões do que as jovens. No entanto, as jovens estão vulneráveis à gravidez precoce e à violência doméstica e sexual, conforme veremos nos capítulos a seguir.

- Os jovens que não freqüentam a escola e sua participação nos grupos da comunidade.

Quanto à participação dos jovens em grupos existentes nos bairros, eles mencionaram que não participam de nenhum tipo de grupo (97,4\%). Portanto, os dados mostram que os jovens que não freqüentam a escola não têm acesso às atividades de lazer e cultura e aos projetos sociais desenvolvidos pelas entidades nos distritos administrativos do Grajaú e Jardim Ângela.

\subsubsection{Conhecendo os pais dos jovens que não freqüentam a escola}

Participaram da pesquisa 52 pais dos jovens que não mais freqüentam a escola das áreas de abrangências das equipes de saúde da família das UBS Jardim Três Corações e Jardim Gaivotas, no Grajaú e da UBS Coimbra e Aracati/Cidade Ipava no Jardim Ângela.

Dos entrevistados, 40,4\% têm menos de 40 anos, 36,5\% estão na faixa etária de 40 a 50 anos, e 19,2\% com 50 anos ou mais. Quanto a raça/cor, os pais referem a cor parda $(61,5 \%)$, negra $(17,3 \%)$ e branca $(19,2 \%)$. 
Quanto à religião, a maioria $(55,8 \%)$ dos pais dos jovens fora da escola dos dois distritos dizem que são católicos, um pouco mais de um quarto deles $(26,6 \%)$ evangélicos e uma minoria $(15,4 \%)$ não tem religião.

No que se refere ao local de nascimento, a maioria nasceu fora de São Paulo, o que indica uma história de migração na família $(78,8 \%)$. Nasceram na cidade de São Paulo somente 21,2\% dos entrevistados. A maioria dos pais mora no bairro há mais de dez anos (61,5\%), o que evidencia uma certa estabilidade em relação ao local de moradia. Quanto ao número de pessoas que moram no domicílio, destacamse com quatro a cinco pessoas $(25 \%)$ e cinco a sete pessoas $(25,0 \%)$. Em relação à renda, $32,7 \%$ dos pais dos jovens dos dois distritos têm renda familiar menor do que $\mathrm{R} \$ 600,00$, portanto os jovens fora da escola vivem em famílias consideradas pobres, às vezes, abaixo do nível de pobreza, conforme critérios estabelecidos para os objetivos do milênio (um dólar, por pessoa , por dia) .

O nível de escolaridade predominante dos pais entrevistados foi primeiro grau incompleto $(42,3 \%)$ sendo maior no Grajaú $(58,3 \%)$. A percentagem de pais que nunca estudaram corresponde nos dois distritos a 15,4\%, sendo 12,5\% no Grajaú e $17,9 \%$ no Jardim Ângela. A maioria dos pais tem dois filhos $(32,7 \%)$ e apenas $9,6 \%$ tem cinco filhos ou mais.

Os pais dos jovens não estudantes, das duas regiões de estudo, classificaram o seu relacionamento com os filhos como bom (38\% no Grajaú e 33\% no Jardim Ângela (Anexo 43)

A maioria dos pais entrevistados revelou gostar de conversar com os filhos $(94,2 \%)$. Conversam sobre os riscos na rua $(28,6 \%)$, amizades e namoro $(28,6 \%)$, conselhos e educação $(26,5 \%)$, drogas $(26,5 \%)$, sexualidade $(22,4 \%)$, voltar a estudar $(22,4 \%)$, família $(16,3 \%)$ e violência (16,3\%). (Anexo 44).

Os dados sugerem que os pais estão preocupados com a violência e com o consumo e tráfico de drogas. A questão da sexualidade pode relacionar-se com a preocupação de uma gravidez não planejada. A escola é vista pelos pais como importante para o desenvolvimento dos jovens e para o seu futuro.

Os pais dos jovens não se dedicam às atividades de lazer, uma vez que permanecem em casa ocupando-se das tarefas domésticas, como cuidar da casa e cozinhar $(73,1 \%)$. As atividades referidas foram: cuidar das crianças $(30,8 \%)$, assistir 
a televisão $(21,2 \%)$, cuidar das plantas e dos animais e trabalhos manuais $(15,4 \%) \mathrm{e}$ conversar com os vizinhos $(11,5 \%)$.

Quando saem de casa, os pais vão à igreja (11,5\%), ou bebem e jogam com os amigos $(7,7 \%)$, o que indica que as mulheres vão à igreja e os homens, para os bares. (Anexo 45).

Quando comparamos estes dados com as opções de lazer citadas pelos jovens, e com a análise dos dados secundários, verifica-se que ainda persiste a falta de opções de atividades de lazer e cultura para os jovens e pais nas duas regiões de estudo.

Mais da metade dos pais dos jovens recebe ajuda de instituições existentes nas duas regiões $(65,4 \%)$. As instituições que ajudam as famílias citadas pelos pais foram Associação Amigos de Bairro (55,6\%) e igrejas (44,4\%) ( Anexo 46).

Nas duas regiões, a ajuda recebida refere-se às necessidades de sobrevivência: cestas básicas $(27,8 \%)$, distribuição de leite $(16,7 \%)$, roupas e alimentos $(16,7 \%)$. Mencionaram ainda melhorias para o bairro $(33,3 \%)$ e cursos $(16,7 \%)$ oferecidos pelas igrejas e entidades (Anexo 47). Comparando os dois distritos, houve diferenças significativas entre as variáveis $(96,0 \%)$, predominando a ajuda recebida pela Igreja no Grajaú e pelas Associações de Bairro, no Jardim Ângela.

As expectativas dos pais dos jovens não estudantes referem-se, em sua maioria, a ter um emprego (78,8\%); na seqüência, a necessidade de educação $(65,4 \%)$, de saúde (55,8\%), moradia (36,5\%), assistência imediata (36,5\%) e segurança $(21,2 \%)$. Comparando os dois distritos, não se verifica dependência significativa entre as variáveis, mostrando que as expectativas são as mesmas para os distritos (Anexo 48).

As situações que geram insegurança para os pais dos jovens fora da escola estão relacionadas às questões de álcool e drogas $(48,1 \%)$, sendo no Jardim Ângela $57,1 \%$ e o Grajaú $37,5 \%$, à violência pessoal $(48,1 \%)$ seguidas de roubos e assaltos (40,4\%), filhos em situação de risco (38,5\%), doenças $(32,7 \%)$ e desemprego $(28,8 \%)$. As situações referidas são semelhantes entre os distritos e não há diferenças significativas entre as variáveis (Anexo 49). 
Os dados apresentados mostram as carências decorrentes das iniqüidades e da falta de oportunidades nas regiões de estudo. Possibilitam constatar que as famílias entrevistadas nos Distritos Grajaú e Jardim Ângela vivem em condições de vida precárias, sem ter as necessidades básicas e de sobrevivência atendidas pelas políticas públicas locais, necessitando contar com a assistência das redes de apoio. Os pais preocupam-se com a violência e com as situações de vulnerabilidade que afetam os jovens, como, por exemplo, o consumo e o tráfico de drogas. O desemprego e a saúde, assim como a educação, são questões importantes na vida das famílias nas regiões de estudo.

- As opiniões dos pais dos jovens que não estudam sobre os jovens

Segundo os pais entrevistados, os principais motivos dos jovens para terem deixado de freqüentar a escola foram: o trabalho $(21,2 \%)$, o desinteresse $(15,4 \%)$, o baixo desempenho escolar $(15,4 \%)$, a falta de vagas $(13,5 \%)$, influências das amizades (5,8\%), entre outros (Anexo 50).

De acordo com os pais, os jovens ocupam o tempo assistindo a televisão (50\%), brincando na rua (32,7\%), jogando futebol $(28,8 \%)$ ajudando em casa $(25,0 \%)$, empinando pipa $(15,4 \%)$ em clubes e associações $(15,4 \%)$, lan house $(13,5 \%)$, visitam amigos e vizinhos (13,5\%), namoram e saem com amigos $(11,5 \%)$ e jogam videogame $(11,5 \%)$ (Anexo 51)

Os relatos dos pais são semelhantes aos dos jovens. Os jovens permanecem a maior parte do tempo na rua brincando, jogando bola ou empinando pipa e na lan house; quando estão em casa, assistem a televisão.

\subsection{A ANÁLISE POR TRIANGULAÇÃO DOS DADOS}

A partir dos resultados e discussões apresentadas, realizou-se a análise por meio da triangulação, considerando os jovens estudantes, não estudantes e os pais dos jovens que não freqüentam a escola. A triangulação foi feita para os motivos apresentados pelos jovens e seus pais por terem deixado a escola, aspectos positivos e negativos da escola segundo os jovens, temas de conversas com os pais e o lazer dos jovens. 
- Jovens estudantes, não estudantes e os pais dos jovens que não freqüentam a escola interpretando a evasão escolar

Os resultados apresentados possibilitam constatar, conforme demonstra-se no

Quadro 2, que os depoimentos dos jovens e dos pais sobre os motivos pelos quais deixaram de freqüentar a escola são semelhantes, havendo diferenças apenas na ordem de citação.

Quadro 2 - Motivos apresentados pelos jovens e pais para não freqüentar a escola, por ordem de citação

\begin{tabular}{|l|l|}
\hline Jovens que não estudam & Pais dos jovens que não estudam \\
\hline (1) Perda de estímulo ${ }^{1}$ & (1) Trabalho (5) \\
\hline (2) Gravidez & (2) Desinteresse (1) \\
\hline (3) Mudança de bairro & (3) Baixo desempenho escolar (4) \\
\hline (4) Baixo aproveitamento e a reprovação & (4) Falta de vaga (6) \\
\hline (5) Começaram a trabalhar & (5) Ninguém sabe \\
\hline (6) Falta de vagas & (6) Influências das amizades \\
\hline (7) Distância e dificuldades com o horário & (7) Casamento (12) \\
\hline (8) Faltas & (8) Gravidez (2) \\
\hline (9) Baixa alta estima e vergonha & (9) Baixa auto-estima (9) \\
\hline (10) Presença de drogas na escola (10) & (10) Excesso de faltas (8) \\
\hline (11) Discussão e brigas com professores & (11) Envolvimento com o tráfico \\
\hline (12) Casamento & (12) Não quis estudar a noite (7) \\
\hline (13) Bagunça e indisciplina & (13) Briga na escola (11) (13) \\
\hline & (14) Nunca foram a escola \\
\hline (15) Violência no entorno da escola, \\
tráfico (10)
\end{tabular}

${ }^{1}$ Foi mais citada entre os jovens de 10 -14anos.

Os depoimentos dos estudantes e daqueles que deixaram de estudar demonstram que, embora os jovens não estejam mais na escola, ela desempenha, ou desempenhou, um importante papel na socialização e na sociabilidade desses jovens. É, ou foi, um espaço de convivência com amigos e professores e de aquisição de 
conhecimentos. As principais dificuldades encontradas referem-se a"bagunça", indisciplina, brigas entre alunos, violência interna entre os jovens e dificuldades estruturais, conforme Quadro 3. É possível verificar, pelos motivos apontados para a evasão escolar, que os problemas não estão somente na escola. É todo o entorno que envolve o jovem e sua família - pobreza, violência, drogas, gravidez precoce - que o move para fora da instituição. As outras instituições, como veremos ao discutir o território, não constituem ações coletivas para resolver os problemas de forma articulada entre si e com a escola. A perda de estímulo manifestada pelos jovens e apresentada também pelos pais como desinteresse, o baixo aproveitamento e a baixa auto-estima e vergonha, apresentados também pelos dois atores, e outros motivos expressam as dificuldades da escola para envolver o aluno a fim de que estes completem o seu desenvolvimento psicossocial e sua formação de cidadão.

Os dados do Quadro 3 confirmam essas informações e demonstram que os alunos que estão na escola correm um sério risco de deixá-la por problemas individuais e do entorno que refletem nela e das políticas públicas existentes e não implementadas que não valorizam as áreas de maior vulnerabilidade social da cidade (“bagunça”, alunos muito violentos, prédio e instalações).

Quadro 3 -Aspectos positivos e negativos da escola segundo os jovens

\begin{tabular}{|l|l|l|}
\hline \multirow{4}{*}{ Jovens estudantes } & Gosta na escola & Não gosta na escola \\
\cline { 2 - 3 } & Amigos e colegas & "Bagunça" e indisciplina \\
\cline { 2 - 3 } & Ensino bom e de qualidade & Prédio e instalações \\
\cline { 2 - 3 } & Aprende coisas novas & Não sabe explicar \\
\cline { 2 - 3 } & Professores são bons e ótimos & Alunos muito violentos \\
\cline { 2 - 3 } Jovens que não & Ambiente bom & \\
\hline \multirow{5}{*}{ estudam } & Gostava na escola & Não gostava na escola \\
\cline { 2 - 3 } & Amigos e dos colegas & Aulas de matemática \\
\cline { 2 - 3 } & Professores , ensino & Professores \\
\cline { 2 - 3 } & & $\begin{array}{l}\text { Brigas entre alunos e } \\
\text { violência }\end{array}$ \\
\cline { 2 - 3 } & Aprender coisas novas & Aula de português \\
\hline & Escola era "legal" & Bagunça e dos colegas \\
\cline { 2 - 3 } & Espaço da escola e do prédio & Direção da escola \\
\hline
\end{tabular}


No Quadro 4 verifica-se que os temas das conversas entre os jovens e os pais não diferem; no entanto, os depoimentos dos pais ressaltam a preocupação com a segurança e a necessidade de os filhos continuarem os estudos. Os depoimentos indicam que os pais depositam na escola a esperança de um futuro melhor para os jovens. As questões do entorno, como drogas e violência, continuam sendo temas de conversa entre os jovens e os pais, e de preocupação. Ultrapassam o âmbito das escolas e não têm sido objeto de ações coletivas e políticas integradas para superálos.

Quadro 4- Temas de conversas com os pais

\begin{tabular}{|l|l|l|}
\hline Jovem estudantes & Jovens que não estudam & $\begin{array}{l}\text { Pais dos jovens que } \\
\text { não estudam }\end{array}$ \\
\hline Escola & Escola & $\begin{array}{l}\text { Voltar a estudar Riscos } \\
\text { na rua }\end{array}$ \\
\hline Amigos e namorados & Amizades & Amizades e namoro \\
\hline Família & Família & Família \\
\hline Sobre o próprio jovem & Relacionamentos, namoros & Sexualidade \\
\hline Drogas & Drogas & Drogas \\
\hline Violência & Trabalho & Violência \\
\hline Tudo & Dia a dia - cotidiano & Conselhos e educação \\
\hline
\end{tabular}

No Quadro 5 observa-se que a sociabilidade dos jovens se dá na rua ou pelo acesso à internet. Os jovens estudantes têm mais acesso à internet, muitas vezes nas lan houses do que os jovens que não freqüentam a escola. Para as jovens que deixaram de freqüentar a escola, resta a opção de cuidar da casa e dos filhos, assistir a TV ou ficar na rua, onde se tornam mais vulneráveis às drogas e à violência. Há pais, com algumas exceções, que mencionam que os filhos ocupam o tempo em clubes e associações do bairro, onde poderiam se envolver em ações positivas para sua formação. 
- Os jovens estudantes, não estudantes e os pais dos jovens que não freqüentam a escola e o lazer

Quadro 5 - Como os jovens ocupam as horas de folgas no DA Grajaú e Jardim Ângela.

\begin{tabular}{|c|c|c|}
\hline Jovens estudantes & Jovens que não estudam & $\begin{array}{l}\text { Pais dos jovens que } \\
\text { não estudam }\end{array}$ \\
\hline $\begin{array}{l}\text { Computador e Internet }{ }^{1} \\
\text { Jogar videogame }^{3}\end{array}$ & & $\begin{array}{l}\text { Lan House } \\
\text { Jogar videogame }\end{array}$ \\
\hline $\begin{array}{l}\text { Jogar bola - atividades } \\
\text { esportivas }^{2} \text {. }\end{array}$ & $\begin{array}{l}\text { Jogar bola } \\
\text { Empinar pipa e andar de } \\
\text { bicicleta }\end{array}$ & $\begin{array}{l}\text { Brincar na rua } \\
\text { Empinar pipa }\end{array}$ \\
\hline Estudar e desenhar & $\begin{array}{l}\text { Arrumar a casa e cozinhar } \\
\text { Ajudar em casa } \\
\text { Cuidar dos sobrinhos e dos } \\
\text { filhos }\end{array}$ & Ajudar em casa \\
\hline $\begin{array}{l}\text { Assistir TV e filmes } \\
\text { Ouvir música em casa }\end{array}$ & Assistir a TV e ouvir som & Assistir a TV \\
\hline $\begin{array}{l}\text { Passear e sair com os } \\
\text { amigos }\end{array}$ & $\begin{array}{l}\text { Visitar amigos e parentes } \\
\text { Conversar com os amigos }\end{array}$ & $\begin{array}{l}\text { Visitar amigos e } \\
\text { vizinhos } \\
\text { Namorar e sair com } \\
\text { amigos }\end{array}$ \\
\hline \multicolumn{3}{|l|}{ Brincar } \\
\hline Dormir & & $\begin{array}{l}\text { Participar de atividades } \\
\text { em clubes e } \\
\text { associações }\end{array}$ \\
\hline & Ficar na rua & \\
\hline
\end{tabular}

${ }^{1}$ Foi mais citado no Distrito do Jardim Ângela.

${ }^{2}$ Foi mais citado no Distrito do Grajaú.

${ }^{3}$ Foi mais citado entre os jovens de 10 a 14 anos. 


\subsection{AS PERCEPÇÕES DAS LIDERANÇAS, EDUCADORES E PROFISSIONAIS DE SAÚDE SOBRE OS JOVENS}

Participaram dessa fase da pesquisa 73 entidades identificadas no levantamento de campo, que desenvolvem projetos e ações destinadas aos jovens da faixa etária de 10 a 19 anos.

Quanto aos educadores, foram entrevistados 70 profissionais da área da educação - diretores ou coordenadores pedagógicos -das escolas municipais e estaduais dos Distritos Administrativos do Grajaú e do Jardim Ângela conforme visto no capítulo Metodologia.

$\mathrm{Na}$ área da saúde foram entrevistados 33 profissionais, coordenadores das Unidades de Saúde com Programa Saúde da Família das Unidades existentes nos distritos administrativos do Grajaú e do Jardim Ângela, conforme critérios descrito no capítulo Metodologia

- Triangulação das opiniões das lideranças, educadores e profissionais de saúde, sobre o lazer e participação dos jovens nos grupos existentes nas regiões

$\mathrm{Na}$ análise por triangulação, conforme quadros abaixo, serão comparadas as respostas das lideranças, educadores, profissionais de saúde sobre as formas de lazer e participação dos jovens nas regiões de estudo.

Quadro 6- Grupos de jovens nas regiões por ordem de citação

\begin{tabular}{|l|l|l|}
\hline Lideranças & Educadores & Profissionais de Saúde \\
\hline Música & Grupos religiosos & Grupos de igrejas \\
\hline Religiosos & Música & Música \\
\hline Teatro & Teatro & $\begin{array}{l}\text { Grupos na Entidade Monte } \\
\text { Azul }\end{array}$ \\
\hline Dança & Projetos de entidades & Grupos de capoeira \\
\hline Ecológicos & Meio ambiente & \\
\hline Hip -Hop & Esportes & \\
\hline Hap & Dança & \\
\hline
\end{tabular}


Quadro 7- Formas de lazer existentes nas regiões segundo entrevistados para os jovens.

\begin{tabular}{|l|l|l|}
\hline Lideranças & Educadores & Profissionais da Saúde \\
\hline Associações Comunitárias & Escola da família & Escola da família \\
\hline Escola da Família & CEUS & Campos de futebol \\
\hline CEUS & Campos de várzeas -futebol & $\begin{array}{l}\text { Atividades das entidades e } \\
\text { associações }\end{array}$ \\
\hline Casa da Cultura & Ruas /praças e quadras & $\begin{array}{l}\text { Parques (Guarapiranga e } \\
\text { Ecológico }\end{array}$ \\
\hline Rua & Quadras das escolas & CEU \\
\hline Parques & Clube da Turma & Casa da Cultura \\
\hline Centro desportivos & Represa & \\
\hline Campos de várzea & SESC & \\
\hline Represa & & \\
\hline SESC Interlagos & & \\
\hline
\end{tabular}

Na análise do Quadro 6, verifica-se, na opinião dos entrevistados, que predominam nas regiões os grupos religiosos e os grupos musicais (Anexos 52,53 e 54). No entanto, a maioria dos jovens estudantes $(62,1 \%)$ e os que deixaram de estudar $(97,4 \%)$ não participam dos grupos citados.

O Quadro 7 apresenta as formas de lazer existentes nas regiões, segundo os entrevistados (Anexos 55,56 e 57). Predominam as atividades oferecidas pelas escolas da família, entretanto, nota-se que os jovens estudantes e não estudantes não participam das atividades oferecidas pelas escolas e entidades das regiões

No Jardim Ângela, as atividades culturais são oferecidas pelas escolas e entidades da região, uma vez que o CEU está em construção e a casa de Cultura pertence à região de M' Boi Mirim.

Na análise do Quadro 8, observa-se que as lideranças, profissionais de saúde e educadores mencionam que os jovens frequientam as escolas da família e a rua, quadras e praças, CEUS e entidades sociais (Anexos(58,59 e 60).).Os jovens, no entanto, revelam dividir o tempo de folga na rua e dentro de casa ajudando nas atividades domésticas, assistindo a televisão e navegando na internet. 
Quadro 8- Lugares mais procurados para lazer pelos jovens por ordem de freqüência

\begin{tabular}{|l|l|l|}
\hline Lideranças & Educadores & Profissionais de Saúde \\
\hline Ruas/ praças e quadras & Escolas da família & Escola \\
\hline $\begin{array}{l}\text { Centros Comunitários e } \\
\text { Entidades }\end{array}$ & Ruas/ praças e quadras & Ruas/praças e quadras \\
\hline Bares e casas noturnas & Campos de futebol & $\begin{array}{l}\text { Parques Guarapiranga e } \\
\text { Ecológico }\end{array}$ \\
\hline Campos de várzea & Quadras das escolas & Clube da Turma \\
\hline Escolas & CEUS & CEU da Cultura \\
\hline CEU & Danceterias e baladas & Bares \\
\hline Lan house & Clubes (da juventude, Criança e \\
& da Turma) & \\
\hline Igrejas & Represa & Bares/lanchonetes \\
\hline & Entidades/ONGS Associações & \\
\hline & & \\
\hline
\end{tabular}

$\mathrm{Na}$ opinião das lideranças, os jovens têm poucas oportunidades de lazer, sendo a rua o lugar mais procurado por eles nos distritos de estudo, o que confirma as informações obtidas dos jovens que expressam um pequeno percentual de participação em programas de entidades da região. Destacam a importância dos CEUS, Escola da Família os clubes e entidades para o lazer dos jovens.

- A percepção dos educadores sobre os jovem e seus problemas na escola

Os maiores problemas mencionados pelos educadores em relação aos jovens na escola nos dois distritos de estudo foram: indisciplina dos alunos $(35,7 \%)$, falta de compromisso, interesse e participação (14,3\%), desrespeito com funcionários $(12,9 \%)$ e destruição do patrimônio escolar, especialmente no Grajaú. Outros problemas foram citados, que não se referem especificamente ao jovem, mas às condições de vida familiar e financeira. Não houve diferenças significativas entre os problemas existentes com os alunos nas duas regiões de estudo (Anexo 61). 
Analisando, de acordo com a faixa etária, verifica-se que, entre os problemas existentes com os alunos da faixa etária de 10 a 14 anos, predominam as dificuldades de aprendizagem (25,7\%), seguidas pela indisciplina (24,3\%), agressividade no relacionamento $(22,9 \%)$ e falta de compromisso e interesse $(21,4 \%)$. Não houve diferenças significativas entre os problemas existentes com os alunos nessa faixa etária nas duas regiões de estudo (Anexo 61).

Entre os jovens de 15 a 19 anos, conforme os educadores, continua aparecendo o desinteresse com a aprendizagem (17,1\%), mas são mencionados outros problemas relacionados à idade, como a gravidez precoce (15,7\%), álcool, fumo e drogas $(14,3 \%)$, falta de perspectivas $(10,0 \%)$, indisciplina $(7,1 \%)$, violência $(7,1 \%)$, dificuldades para obter trabalho $(7,1 \%)$ e problemas familiares $(7,1 \%)$ Anexo 61

- A percepção dos problemas de saúde dos jovens pelos profissionais de saúde

Quando se compara a percepção dos educadores sobre os problemas verificados na escola com a percepção dos profissionais de saúde, evidencia-se que estas são semelhantes. Segundo os profissionais de saúde, os principais problemas dos jovens das regiões são: a gravidez precoce $(45,5 \%)$, sendo mais referida no DA do Grajaú (58,3\%); a dependência de álcool e drogas $(39,4 \%)$; situações relativas à sexualidade $(36,4 \%)$; DST $(21,2 \%)$; e violência $(18,2 \%)$. Os dados sugerem que estes problemas afetam mais os jovens na faixa etária de 15 a 19 anos. Enquanto as doenças respiratórias $(21,2 \%)$, doenças comuns da idade $(18,2 \%)$ e problemas de comportamento $(15,2 \%)$ provavelmente afetam mais os jovens de 10 a 14 anos (Anexo 62). 


\section{A SUBJETIVIDADE DOS JOVENS E AS CONSTRUÇÕES SOCIAIS SOBRE A JUVENTUDE: O QUE É SER JOVEM?}

Ser jovem é se divertir e brincar muito, mas também estudar e começar a pensar na vida e no futuro.

(Jovem entrevistado)

Neste capítulo serão apresentadas as percepções dos jovens, dos pais dos jovens que não freqüentam a escola, lideranças, educadores e profissionais de saúde, sobre o que é ser jovem. Os discursos foram elaborados utilizando a técnica do Discurso do Sujeito Coletivo - DSC (LEFÈVRE e LEFÈVRE, 2000).

\subsection{ANÁLISE DOS DISCURSOS DO SUJEITO COLETIVO DOS JOVENS ESTUDANTES E NÃO ESTUDANTES}

Na construção dos Discursos do Sujeito Coletivo sobre o que é ser jovem, que abrangeu os jovens de 10 a 19 anos, estudantes e não estudantes dos Distritos do Grajaú e do Jardim Ângela, obtivemos dez categorias numeradas de A a J, conforme figura abaixo:

Figura 2- Resultados Quantitativos do DSC dos jovens - Idéia Central - fale sobre o que é ser jovem.

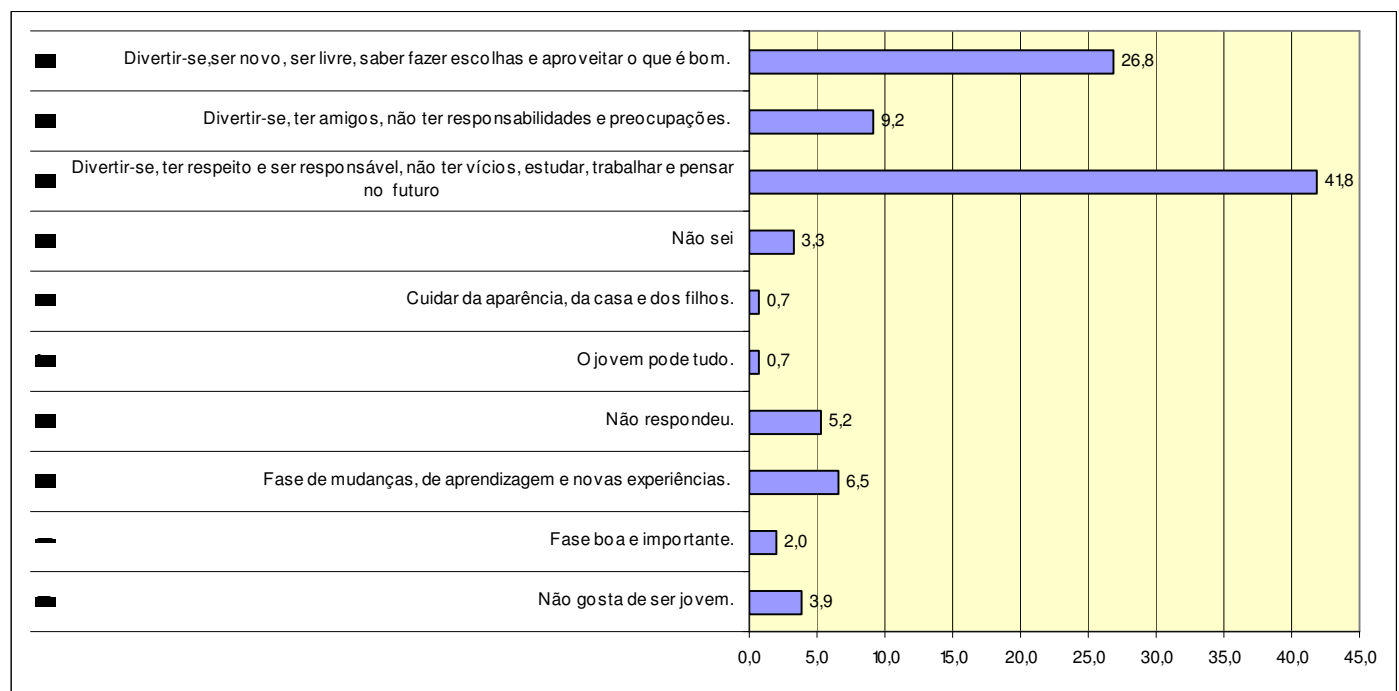

Total da Pergunta: 153 
Verifica-se que o discurso predominante dos jovens é divertir-se, ter respeito e ser responsável, não ter vícios, estudar, trabalhar e pensar no futuro com 64 respostas (41,83\%), seguido do discurso ser jovem é divertir-se, ser novo, ser livre, saber fazer escolhas e aproveitar o que é bom com 41 respostas $(26,80 \%)$

Os DSCs dos jovens estudantes e não estudantes permitem constatar a importância dada à família, ao trabalho e aos estudos. Estudar é visto como necessário para garantir um futuro melhor. Os jovens consideram que uma gravidez não planejada pode comprometer o projeto de vida. Ter um bom futuro significa estudar, ter um bom emprego e constituir família, como pode ser constatado no discurso a seguir e Anexo 63:

DSC - Divertir-se, ter respeito e ser responsável, não ter vícios, estudar, trabalhar e pensar no futuro.

Ser jovem é se divertir e brincar muito, mas também estudar e começar a pensar na vida e no futuro. É curtição, saber viver, mas primeiro tem que estudar e depois trabalhar, ter consciência, não abusar e não ficar fazendo burrada. Deve ser responsável, estudar, fazer cursos, ajudar a mãe, arrumar casa, ver televisão, ir pro salão, quem sabe pegar ferro velho para ganhar dinheiro.É sonhar com um futuro melhor e ter força de vontade para conquistá-lo. Deve-se estudar para ser alguém na vida e ter um emprego. É estar com as pessoas e fazer coisas boas para os outros, sem pensar em recompensa, respeitar uns aos outros e a si próprio e aprender com os erros. É não usar drogas, não ter filhos cedo e não ter medo de ser feliz.

É bom demais! É crescer rápido, ser novo e aproveitar, mas se divertir quando tem que se divertir.

Comparando os DSCs dos jovens fora da escola e na escola dos dois Distritos, não se constatam diferenças. Os jovens atribuem importância aos estudos, ao trabalho e ao não envolvimento com drogas. Embora considerem que esta é uma fase na qual se deve divertir e "curtir a vida", enfatizam a importância de ser responsável -“viver e deixar viver”, conforme Anexo ( 64).

Outro DSC que predominou, de acordo com os depoimentos dos jovens, foi:

\section{Divertir-se, ser novo, ser livre, saber fazer escolhas e aproveitar o que é bom.}

Nesse discurso, os jovens enfatizam a importância da liberdade, da diversão, da aquisição de novas experiências nesse momento da vida e ainda têm a percepção das responsabilidades que deverão assumir no futuro. 
Os jovens consideram que é importante lutar pelos direitos, deveres e aproveitarem as oportunidades existentes. Reconhecem que, se não souberem fazer boas escolhas, terão o projeto de vida prejudicado. O casamento é visto como um obstáculo para a diversão e para os estudos, como pode ser verificado a seguir:

DSC - Divertir-se, ser novo, ser livre, saber fazer escolhas e aproveitar o que é bom.

Ser jovem é bom é da hora, não tem explicação! É divertir-se, brincar, sair, curtir a vida, ter amigos, viver e ser feliz. É uma coisa boa, ser novo, sair, ir para qualquer lugar, aproveitar tudo que é de bom. Sei lá, tem mais privacidade, a mãe não se mete na sua vida. Pode-se fazer as coisas que os adultos não podem.

É viver, saber fazer escolhas para não se ferrar. Tem que saber escolher as amizades. Terminar os estudos e só depois trabalhar. Aproveitar enquanto é novo, ficar, namorar, depois que casa muda tudo.

É tudo de bom! Conhecer coisas novas, viajar, aprender e quebrar a cara. Aproveitar ao máximo e ter novas experiências. Ser jovem é tudo.

É ter respeito ao próximo e a si mesmo. Lutar pelos seus direitos. É apreciar as coisas belas que a vida nos oferece e não deixar escapar as boas oportunidades. É a melhor fase que se tem na vida. É ser inteligente, esperto e muito mais.

É pular, correr, rir, dançar, viver a vida. Enfim, ser!

É uma fase ótima, você sabe o que é certo e o que é errado. Conhece novas pessoas, faz novas amizades, diverte-se com os amigos, namora bastante e pode ter uma vida totalmente independente. $E$ ser alegre e feliz com as coisas da vida e conhecer tudo o que o mundo pode proporcionar.

É aproveitar enquanto temos essa idade sem fazer coisas ruins e tem várias oportunidades huhuhuhu!!!

É divertido ser jovem, brincar com boneca, pular corda, jogar bola, fazer outras coisas. É deixar de ser criança, ir comprar pão e ir para a escola. É ser um pouco adolescente, gostar de ser livre e caminhar para um futuro.

É a melhor época das nossas vidas. É nessa fase que fazemos nossas escolhas, certas ou erradas, que vão fazer o nosso futuro.

Comparando os discursos dos jovens na escola e fora da escola, das duas regiões, construídos para essa categoria, não se constatam diferenças. Os jovens, apesar de não freqüentarem mais a escola, consideram que estudar é importante para ter um bom futuro, assim como um bom trabalho. Há jovens que não estudam, estão casadas e expressam o sentimento de infelicidade diante das responsabilidades assumidas porque percebem que o casamento mudou a sua vida.

A diversão sem responsabilidade aparece com 14 respostas $(9,15 \%)$. Ser jovem é divertir-se sem preocupações, "sem pensar no amanhã", mesmo neste discurso, percebe-se que os jovens atribuem importância aos estudos e à necessidade de se prepararem para o futuro. Ressalta-se a importância de viver a juventude e não assumir responsabilidades como, por exemplo, uma gravidez precoce. 
Os jovens também consideram a juventude como uma fase de mudanças e de transição. Relatam no discurso que nesta fase de descobertas, em que "se aprende com a vida”, muitas vezes são incompreendidos e julgados pelos adultos. Foram dez respostas $(6,54 \%)$.

Temos ainda os seguintes discursos - Não gostar de ser jovem com seis respostas $(3,92 \%)$, quando os depoimentos dos jovens mostram que não é tão bom ser jovem. Nesses depoimentos verifica-se que não é possível pensar a juventude apenas como uma fase despreocupada e de diversão. Os jovens precisam assumir responsabilidades devido às necessidades de sobrevivência e das escolhas que fazem. Crescer, para alguns, implica perdas materiais e afetivas. Essas perdas demonstram que os jovens vivenciam todos os tipos de carência no cotidiano. A gravidez não planejada aparece como um dos motivos que compromete o futuro, sendo uma das causas da evasão escolar e da dificuldade para ingressar no mercado de trabalho.

DSC - Não gosta de ser jovem

E não entendo, porque não curto tanto ser jovem e crescer. Ser jovem é diversão, curtição e eu não gosto disso, queria trabalhar. Por outro lado, quando se cresce a roupa não serve mais, você tem que cuidar das coisas. Ser jovem não é tão bom quando se está grávida e tem filhos. Aí o futuro está condenado, você fica cuidando do filho. Ser jovem é também crescer, deixar nossos pais, e eu queria ser o bebê da minha mãe e do meu pai pro resto da vida.

Analisando os DSCs dos jovens, utilizando o referencial teórico sintetizado na Figura 1, que sintetiza o referencial da pesquisa,percebe-se que os jovens, em seus discursos, revelam uma grande energia vital, englobando o bem-estar físico representado pela disposição que têm para estudar, trabalhar, divertir-se, namorar ser livre e aproveitar tudo o que há de bom na vida. Na vida comunitária, amigos, namorados, pais desempenham papel fundamental, assim como a escola, para o desenvolvimento de habilidades, aquisição de conhecimentos e para realização do projeto de vida.

No entanto, os jovens que não freqüentam mais a escola citam desmotivação, perda de estímulo, o que faz supor que a escola já não atende mais as necessidades desses jovens. O desinteresse e a perda de estímulo, muitas vezes, podem ser 
atribuídos à organização de conteúdos, métodos de ensino e ao papel desempenhado pelo professor, que fica restrito ao desenvolvimento de sua disciplina.

O desinteresse pode ser atribuído também aos novos papéis que os jovens assumem, como vimos os jovens que não freqüentam a escola referem gravidez não planejada e necessidade de trabalhar. No entanto, revelam o desejo de estudar, mesmo percebendo que não terão oportunidades. Outros foram obrigados a deixar a escola por dificuldades de acesso, freqüentes interrupções, baixo aproveitamento e reprovação.

Embora os jovens tenham a expectativa de que por meio dos estudos conseguirão viabilizar o seu projeto de vida, a escola apresenta limitações para atender suas necessidades biopsicossociais, formá-los para o desenvolvimento de um projeto de vida, preparando-os para o mercado de trabalho, por meio de um ensino de qualidade e que contemple o jovem em sua integralidade. É socialmente reconhecido que a satisfação das necessidades é em parte devida à apropriação dos benefícios advindos da educação escolar, que permite formar sujeitos autônomos para a vida pública e privada (SPÓSITO, 2004).

Entretanto, os jovens têm dificuldades de acesso a educação, cultura, lazer e trabalho Aqueles que deixaram de estudar e trabalham não exercem atividades qualificadas. O trabalho é muito mais que um instrumento de sobrevivência, constitui o substrato da identidade masculina, é condição de uma autonomia moral, ou seja, da afirmação positiva de si (SARTI, 2007). Essa disposição para o trabalho, vivida como o fundamento da autonomia, relaciona-se com a saúde. Para ter disposição para o trabalho, é preciso ter saúde física e mental, assim como para "curtir a vida". A saúde é um valor que se relaciona com o trabalho e com a disposição para a vida. $\mathrm{O}$ corpo e a mente são instrumentos para o trabalho e para a vida social.

Predomina entre os jovens a visão da juventude como fase de transição para a vida adulta e a visão da juventude como liberdade, no entanto os jovens pesquisados incorporam as expectativas dos familiares, têm consciência das responsabilidades que deverão assumir, e muitos já assumem, como foi observado entre os jovens que deixaram de freqüentar a escola. Desses, muitos assumem as responsabilidades do casamento e da gravidez não planejada. Ser jovem, muitas vezes para as meninas, é cuidar dos filhos e da casa, do marido, reproduzindo a vida dos pais, sendo esta a 
única alternativa que lhes restam; porém, os jovens sonham com a liberdade individual e a conquista progressiva de uma autonomia, que será alcançada com a entrada no mundo adulto.

No que se refere à juventude em sua sociabilidade, o lazer, simbolicamente, concentra "o descompromisso' socialmente permitido antes das responsabilidades adultas e desempenha papel fundamental na formação da visão de mundo, na construção da identidade e no enfrentamento dos tabus culturais" (MINAYO, 1999, p. 50). Os jovens de estudo, em sua maioria, não têm atividades de lazer. As jovens consideram lazer desempenhar atividades domésticas, entre elas cuidar de filhos e sobrinhos.

Os discursos dos jovens mostram os conflitos, entre o desejo e a realidade, entre o desejo e as possibilidades existentes. Valorizam a família, mas querem ter liberdade; querem crescer, entretanto isso significa assumir responsabilidades; valorizam os estudos para o futuro, porém alguns já não têm mais acesso à escola; querem um bom trabalho, todavia alguns vivem de fazer "bicos". Para os jovens deste estudo, no momento da juventude, são esses conflitos que possibilitam a constituição da subjetividade e a formação do jovem como sujeito social. É na relação entre a identidade integrativa e conflitual que desponta a construção do sujeito (SCHALLER, 2002).

Os jovens que participaram desta pesquisa, especialmente os que foram excluídos, ou se excluíram da escola, aspiram a melhorar de vida, deparam-se com a competitividade acirrada e as desigualdades de acesso, decorrentes de sua precária formação e se frustram. O projeto de serem sujeitos autônomos, como demonstraram em seu discurso sobre o que é ser jovem, é inviabilizado em razão da falta de oportunidades e perspectivas.

As oportunidades e os obstáculos que os jovens experimentam nessa fase influenciarão a passagem para a vida adulta, conseqüentemente, também o lugar que ocuparão na escala social. Alguns obstáculos são inerentes ao mundo do jovem e outros são reflexos das transformações por que passa a sociedade brasileira (CAMARANO et. al, 2004). 
A juventude, desses indivíduos dos distritos de nosso estudo, estejam eles,na escola ou fora da escola, em um ou outro distrito, que não diferem substancialmente um do outro, que são periféricos e com muita falta de infra-estrutura e recursos, constitui uma fase de vida vulnerável. Nessa etapa, em que as características dos indivíduos são delineadas, eles passam, mais que os outros, por situações de conflitos e rupturas, justamente quando têm que definir o seu caminho e conseguir os meios para trilhá-lo. Não dispõem, em sua jornada, especialmente os que deixaram a escola mais cedo, de informações e experiência suficientes para fazer boas opções e às vezes fazem más escolhas, que repercutirão no futuro (CAMARANO e MELLO, 2004, p.14).

Diante das dificuldades e das condições de vida nos Distritos do Grajaú e Jardim Ângela, fica evidente a ausência de políticas públicas destinadas à juventude e o reconhecimento dos jovens como sujeitos de direitos.

\subsection{ANÁLISE DOS DISCURSOS DO SUJEITO COLETIVO DOS PAIS DOS JOVENS NÃO ESTUDANTES}

- Fale sobre o que é ser jovem -

Figura 3- Resultados Quantitativos do DSC Pais dos jovens-Idéias Central -Fale sobre o que é ser jovem

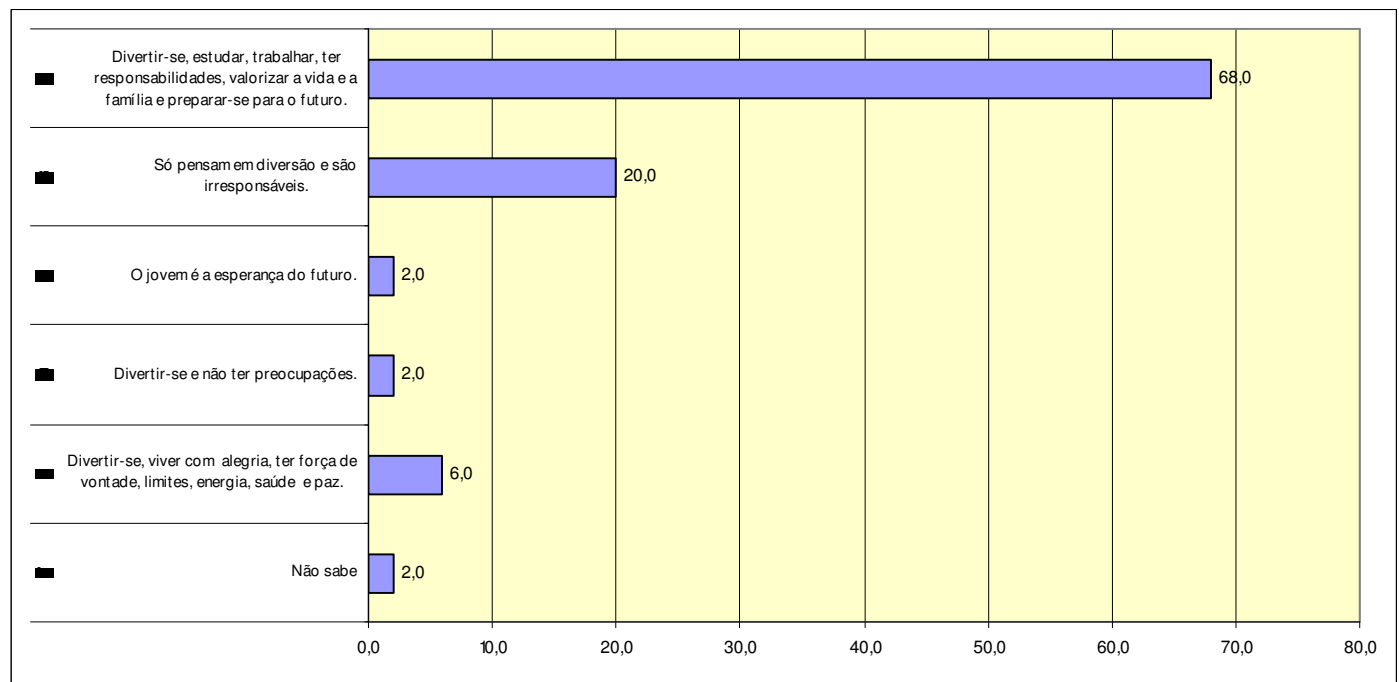

Total de respostas da pergunta: 50 
Verificam-se dois tipos de discursos do que é ser jovem entre os pais: a maioria (68\%) considera que ser jovem é Divertir-se, ter responsabilidades, valorizar a vida e a família e preparar-se para o futuro (34 respostas) e $20 \%$ considera que os jovens são irresponsáveis e só pensam em diversão (dez respostas).

Ser jovem é uma fase de transição, para os pais, na qual os jovens devem aproveitar as oportunidades que surgem; no entanto, ressaltam a importância da responsabilidade e ao mesmo tempo relativizam: "os jovens não sabem o que fazem, precisam aceitar o conselho dos mais velhos e o apoio da família”. Destacam também a preocupação com as situações de vulnerabilidades às quais os jovens estão expostos, entre elas a influência das "más companhias” e o acesso às drogas.

Segue o discurso:

DSC - Divertir-se, ter responsabilidades, valorizar a vida e a família e preparar-se para o futuro.

Ser jovem é uma transição constante, mas devem divertir-se, viver plenamente, curtir a vida, viajar, dançar, namorar, ser meigo, tranqüilo, porque as coisas acontecem no tempo determinado, não devem se precipitar porque nunca vão alcançar a perfeição. É gostar de se divertir, usar roupa bonita e passear com os amigos. Devem terminar os estudos, ser responsáveis, aproveitar as oportunidades que a vida proporciona e trabalhar.

É pensar como adulto, pensar um pouco sobre o mundo, ter responsabilidade, estudar e ser feliz com a escola. É saber o que quer, ter sonhos e procurar coisas boas na vida, não andar com gente errada, não se envolver com drogas e mortes, conhecer os amigos com quem se envolvem e ir em busca dos seus objetivos com força de vontade.

É procurar crescer, entender mais os pais, ter respeito pelos pais e pelos mais velhos. É preparar-se para a vida, fazer cursos, praticar esportes, preparar-se para o mercado de trabalho e construir um futuro estável.

Não devem ter cansaço e preguiça, devem lutar, buscando melhorar a cada dia, respeitando os limites para não errar. Na idade de 15 anos já têm cabeça e sabem o que estão fazendo, precisam aceitar os conselhos dos mais velhos e ter apoio da família.

O segundo discurso que predominou entre os pais dos jovens foi a visão dos jovens como irresponsáveis e como "problemas". Nesse discurso, segundo os pais, os jovens "não querem saber de nada". Consideram que a juventude é uma fase difícil e que têm dificuldades de entender os jovens, salientando a necessidade de ter "alguém para conversar com eles", conforme pode ser visto no Anexo 65 e no discurso a seguir: 
DSC - Só pensam em diversão e são irresponsáveis.

"É menor de idade, adolescente, criança, sei lá. Não sabem o que faz, não pensam em nada, só querem curtir a vida. Não pensam no futuro. Não sei o que dizer, hoje em dia está complicado. Acham que estão crescendo, vão se sentindo adultos e acham que podem tudo, namorar, casar. São vaidosos, não querem saber de nada, às vezes não entendem, quer andar pela sua cabeça, não é assim, tem que amadurecer e não ser criança cada dia que passa. Eles deveriam ter mais responsabilidades, obedecer a Deus e aos pais. São teimosos, acham que tudo podem e nós não sabemos nada. É uma fase difícil para agüentar eles.Tem que ter uma pessoa para conversar com eles.

É um a expectativa do futuro. É tão difícil falar deles. Estão irresponsáveis. não querem nada na vida. Coitado do nosso país!

Comparando os discursos dos jovens com os discursos dos pais dos jovens que deixaram de freqüentar a escola, verifica-se que são complementares. Tanto os jovens como os pais consideram a juventude uma fase de transição para a vida adulta, na qual devem se preparar para o futuro. Ambos entendem que esta é uma fase de diversão, mas que devem ter responsabilidades, estudar e trabalhar. A falta de liberdade sentida pelos jovens é justificada pelos pais, por meio da preocupação com os riscos de eles se envolverem com drogas e más companhias.

Observa-se, nos discursos dos pais, a importância atribuída aos estudos para o ingresso dos jovens no mercado de trabalho; no entanto, os jovens referem que abandonaram a escola por falta de estímulo, gravidez precoce, mudança de bairro, baixa aprovação e reprovação. Os pais, por sua vez dizem que os filhos tiveram que parar de estudar, pois necessitavam trabalhar e também por desinteresse, baixo desempenho escolar, falta de vagas e influências das amizades.

Os depoimentos dos jovens e seus pais mostram as contradições e ambigüidades das relações estabelecidas entre alunos e escola, caracterizadas não só pela exclusão, mas pela intermitência, matrículas sucessivas, abandonos, interrupções.

Segundo SPÓSITO (2004), “as trajetórias escolares são condições 'necessárias' de inserção e de sobrevivência no mercado de trabalho, mas não constituem condições 'suficientes' para ancorar todo o conjunto de expectativas anteriormente atribuídas ao projeto escolar, aspirações ainda consolidadas nas representações das famílias" (SPÓSITO, 2004, p.184). 
A autora ressalta que a inexistência de referências capazes de estruturar novos sentidos para a busca da educação sistemática se inscreve em situações paradoxais: "A ausência de significados positivos para a vida escolar caminha ao lado de novas exigências de domínio das linguagens, informações, conhecimento, enfim de todo um campo de atividade simbólica contemporânea que pressupõe o domínio de habilidades a serem adquiridas na escola" (SPÓSITO, 2004, p.184-185).

Na realidade a importância atribuída à escola pelos pais e jovens, visando prepará-los para um futuro mais promissor, não é condizente com a prática, pois não tem provocado adesões fortes à instituição escolar. A escola, por sua vez, tem apresentado dificuldades para alterar procedimentos consagrados de exclusão e para empreender novos caminhos.

Dessa forma, o modelo de escolaridade voltado para a mobilidade social convive com o enfraquecimento da capacidade socializadora da escola como instituição formadora de novas gerações. Um dos principais desafios é a busca de novas alternativas que possibilitem à escola redefinir sua presença no universo das crianças e adolescentes, visando alcançar algum significado efetivo no desenvolvimento desses sujeitos (SPÓSITO, 2004).

Constata-se, ainda, que a percepção de alguns pais sobre a juventude como uma fase difícil, de problemas e de irresponsabilidades, também é percebida pelos jovens. Estes incorporam a visão dos pais em seus discursos, quando relatam que é uma fase na qual se ocasionam muitas preocupações para os pais. No entanto, os discursos dos jovens mostram que eles não querem apenas se divertir, mas que têm um projeto, no qual se incluem estudo, trabalho e família, para construir um futuro melhor.

No debate sobre a juventude, verifica-se que é comum os jovens serem associados à marginalização e à criminalidade, ao "não querer nada com a vida". Todas essas questões caracterizam a juventude pela ótica pessimista (CAMARANO e MELLO, 2004) e de "crise" - noção que traz consigo a possibilidade de ruptura, tema freqüente nos estudos sobre juventude, como apresentado no capítulo sobre os jovens deste estudo. 


\subsection{ANÁLISE DOS DISCURSOS DO SUJEITO COLETIVO DAS ENTIDADES E LIDERANÇAS}

- Fale sobre o que é ser jovem.

Gráfico 3- Resultados Quantitativos do DSC das Entidades e Lideranças -Idéias Centrais - Fale sobre o que é ser jovem

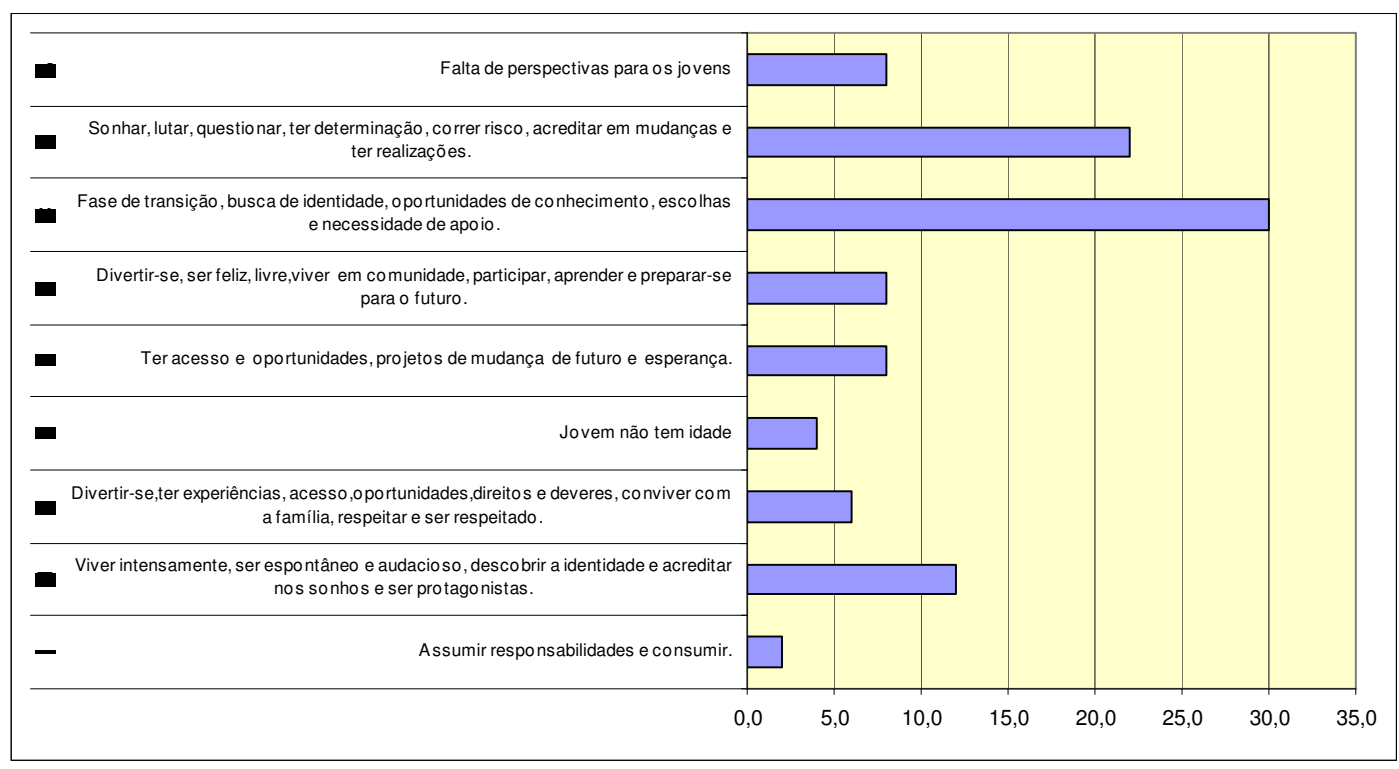

Predominam, entre as lideranças, o discurso da juventude como fase de transição e de necessidade de apoio para a formação da sua identidade, com 15 respostas (30\%), e o discurso da juventude como uma fase de sonhos, de risco e de acreditar em mudanças para obter realizações, com 11 respostas $(22 \%)$.

O DSC predominante mostra que, para as lideranças, a juventude é uma fase de transição para a vida adulta e de moratória - momento de aperfeiçoamento individual de desfrute do prazer e do lazer, antes da assunção das responsabilidades da vida adulta (MADEIRA e RODRIGUES, 1998). Para as lideranças, o Estado tem que garantir, para a juventude, esta moratória e não se evidencia a coresponsabilidade pelo desenvolvimento do jovem, pelas entidades entrevistadas.

Destacam a importância do apoio e proteção aos jovens. Nessa fase há necessidade de limites, valores, ter sonhos e construir o projeto de vida. Estão presentes nos discursos as dimensões física, social e emocional da saúde para o crescimento do jovem e a importância da autonomia e formação do jovem como sujeito social, conforme pode ser visto a seguir: 
DSC - Fase de transição, busca de identidade, oportunidades de conhecimento, escolhas e necessidade de apoio.

Ser jovem é uma fase de transição para o mundo adulto, onde é fundamental ter limites, valores, alimentar sonhos e ter projetos de vida. É um momento peculiar da vida, onde começam a desenvolver opiniões, formar crenças e valores, a buscar novas formas de expressão e conhecer o mundo.É uma fase de transição psicológica, biológica, neurológica e afetiva muito grande. É uma fase muito dolorida porque, a mesmo tempo que ele é criança, ele tem que assumir regras da sociedade.Você não pode ser irresponsável, mas também não pode pegar tanta responsabilidade. Tem que ter possibilidades de errar, consertar e fazer escolhas.

O jovem busca oportunidades que não são necessariamente financeiras, ou seja, oportunidade de desenvolver o seu potencial criativo e produtivo e que vai implicar no adulto que eles vão se tornar.

Eles não têm noções de muitas coisas que fazem, passam por transformações, revoltas, não entendem. Eu sou jovem porque procuro entender essa nova geração, entender a cultura, a moda, para entrar no meio deles.

Eles estão descobrindo as maravilhas do mundo, têm perguntas, questionamentos, trazem mensagens do que precisa mudar e procuram alternativas. É um momento peculiar de desenvolvimento $e$ precisam de respaldo afetivo, psicológico e social.

Ser jovem é inovar, se atualizar, buscar o novo, aproveitar as oportunidades, correr atrás.Neste processo de transformação há muitas cobranças e não está claro para eles. Eles têm dúvidas, preocupam-se mais com os sonhos e com os hormônios.

Ser jovem é ser dinâmico, questionador, querer conhecer tudo e todos, ter desejos de aprender sempre, ter interesse de ajudar, pois é ajudando que se é ajudado. É poder experimentar, de forma sadia as oportunidades que o mundo oferece, e o Estado tem que garantir à juventude essa moratória, para que a sua escolha possa ser mais próxima dos seus desejos e sonhos.

É olhar de modo diferente, buscar horizontes, contribuir com sua família, aproveitar com muita sabedoria, constituindo a sua personalidade.

É ser irreverente, ultrapassar os desafios, mas necessitam de suporte.

Devem ter autonomia de escolha do que fazer, e ter um lugar ou alguém, para expor o que querem e orientação certa, se não acabam se desenvolvendo de forma errada.

É você ter oportunidade de estudar, se formar e ser cidadão.

O DSC abaixo mostra que as lideranças entrevistadas valorizam, para o desenvolvimento do jovem, a força de vontade, a persistência, a criatividade, a necessidade de lutar para alcançar os objetivos e enfrentar desafios. A juventude é vista como uma possibilidade de mudanças para um mundo melhor. Para as lideranças, é a educação que pode ajudar o jovem a crescer e desenvolver-se como sujeito social, conforme pode ser visto no DSC Anexo 66 e no que segue: 
DSC - Sonhar, lutar, ter determinação, correr riscos, acreditar em mudanças e ter realizações.

Ser jovem é ter força de vontade, lutar pelos seus objetivos e, mesmo diante de tantas dificuldades, sempre ser perseverantes e nunca desistir de seus sonhos Acreditar que é capaz, que você pode, que tudo vai melhorar no futuro e que você tem uma vida pela frente.

$E$ enfrentar desafios com soluções reais para vencer e ultrapassar os limites.

Ser jovem é arriscar, ter liberdade para errar, ter idéias boas, sonhos bons e adrenalina para queimar. Se não queimar vai para o outro lado.

É vida, é tudo, é sonhar, é o futuro do nosso mundo, é um paraíso, um livro.

É maravilhoso, ter objetividade, ir para luta, se tem que buscar ele vai atrás. É a esperança de mudança para o futuro. Ser jovem é ensinar os adultos a terem disponibilidade para agir, com coragem, busca e risco.

O jovem sempre vai ter um olhar diferente do adulto que desiste mais fácil. Eles têm o poder de mudanças e decisão, depois vão perceber que existe uma maior dificuldade e excesso de confiança.

É uma pessoa aberta para o novo, através da educação e de cursos ele enfrenta o mundo moderno e dá a volta por cima.

Ser jovem é viver a idade, não procurar ser adulto, buscar viver os seus sonhos, questionar, vivenciar ações, loucuras e realizar algo. É nessa fase de experimentações que ele solidifica o cidadão que deseja ser. É somente isso que vem à minha cabeça neste momento..

Os DSCs construídos a partir dos depoimentos das lideranças dos distritos deste estudo apresentados e os constantes no anexo mostram a importância da formação da identidade, a busca da autonomia e o projeto de vida.

A juventude é vista pelas lideranças como uma fase de intensa energia física, de preocupar-se com os hormônios (com isso todos concordam). Os jovens devem aproveitar todas as oportunidades que a vida lhes oferece para o seu desenvolvimento biopsicossocial. Consideram que os jovens são receptivos às mudanças e inovações, devem correr ricos e enfrentar desafios. "Devem questionar, revoltar-se, fazer escolhas, desenvolver seu potencial criativo e produtivo, ter sonhos e projetos para o futuro, ter força de vontade, acreditar em mudanças, acreditar num futuro melhor, ter oportunidade de estudar, formar-se e torna-se um cidadão".

É atribuída aos jovens a responsabilidade de gerir o amanhã da nação e decifrar os novos códigos e conteúdos, que estão emergindo no novo modelo de sociedade, mas nos distritos, onde estamos desenvolvendo nosso estudo, não há infra-estrutura, nem apoio social suficiente para os jovens se formarem a fim de gerir o amanhã, a não ser obtendo recursos e oportunidades de outras formas, como a aproximação com grupos ligados ao tráfico, conforme discurso a seguir que finaliza esta sessão. Nessa argumentação percebe-se que, apesar das diferenças sociais de 
classe, de gênero, de idade e de etnia, existe uma identidade ou marca própria dessa etapa de vida - a criatividade e as potencialidades para mudar e transformar - que de uma forma ou de outra acaba sendo formada, conforme MADEIRA e RODRIGUES (1998).

As lideranças, além de ressaltarem as potencialidades dos jovens, trazem a dimensão dos direitos e dos deveres. Os jovens são portadores de direitos e deveres: devem ter moradia, possibilidade de convivência familiar, boa educação em casa e na escola, ter acesso a entretenimento, cultura, esporte, lazer, oportunidade de experiência e vida pública, ter carinho, ser respeitado, saber respeitar aprender com os mais velhos, e também, ser protagonistas da sua história.

Um outro argumento presente nos discursos das lideranças é o do jovem como protagonista. Conforme MAGALHÃES (2006), "é possível afirmar que o discurso do protagonismo juvenil seja uma resposta à expectativa adulta de reencontro da juventude com a política, porém, de uma juventude ampliada de faixa etária e origem social que faz uma política também transformada" (MAGALHÃES 2006, p.18).

Conforme a autora, permanece o mito do jovem como agente político; “ durante a década de 80 e 90, até os dias de hoje, os pesquisadores seguem reagindo à imagem de apatia, individualismo e conformismo juvenis, e vêm procurando a ação política na juventude. O protagonismo juvenil é a resposta a essa procura" MAGALHÃES (p.21).

Contrapondo-se à visão dos jovens como potencialidade, tem-se o discurso dos jovens sem perspectivas, sem incentivos e oportunidades nas regiões onde vivem. Neste DSC as lideranças entrevistadas consideram que a necessidade de sobrevivência tira a oportunidade dos jovens de viver a sua juventude. Eles não têm tempo, têm que correr atrás da sobrevivência. Os sonhos se acabam rápido, tornamse adultos muito cedo e se envolvem em crime pra suprir suas necessidades. Referem ainda que as escolas públicas têm poucos recursos para atender as necessidades de aprendizagem dos jovens e as entidades têm dificuldades para investir nos jovens. 
DSC - Falta de perspectivas para os jovens

A juventude nossa não tem muita perspectiva não. Nessa região é muito difícil ser jovem, pela falta de incentivo e oportunidades. Eu considero que ser jovem hoje é muito difícil, não deveria mas é. A escola pública possui o ensino mínimo, temos jovens na oitava série que não sabem escrever o próprio nome. Jovens sem perspectivas. A gente tenta, mas não dá tempo de investir neles.

Para eles é muito difícil, o tempo todo é tirado a oportunidade de ser jovem, de se preparar, conhecer as coisas, gerenciar novas coisas. Eles não têm tempo, tem que correr atrás da sobrevivência. Os sonhos se acabam rápido, tornam-se adultos muito cedo e se envolvem em crime pra suprir suas necessidades.

Os DSCs das lideranças mostram, portanto, o confronto entre a visão "otimista" e "pessimista" sobre os jovens. De um lado, os jovens são a esperança de um futuro melhor, de uma sociedade menos desigual e humana, são protagonistas e atuam para transformar a realidade e, de outro, o jovem sem perspectivas enreda-se no mundo do crime para sobreviver. O interessante é verificar que as lideranças não se colocam como co-responsáveis na resolução da questão nem apresentam propostas das instituições que representam para resolver o problema da juventude no território onde as instituições que dirigem atuam.

\subsection{ANÁLISE DOS DISCURSOS DO SUJEITO COLETIVO DOS PROFISSIONAIS DA EDUCAÇÃO}

Figura 5- Resultados Quantitativos do DSC dos profissionais da educação - Idéias Central - Fale sobre o que é ser jovem

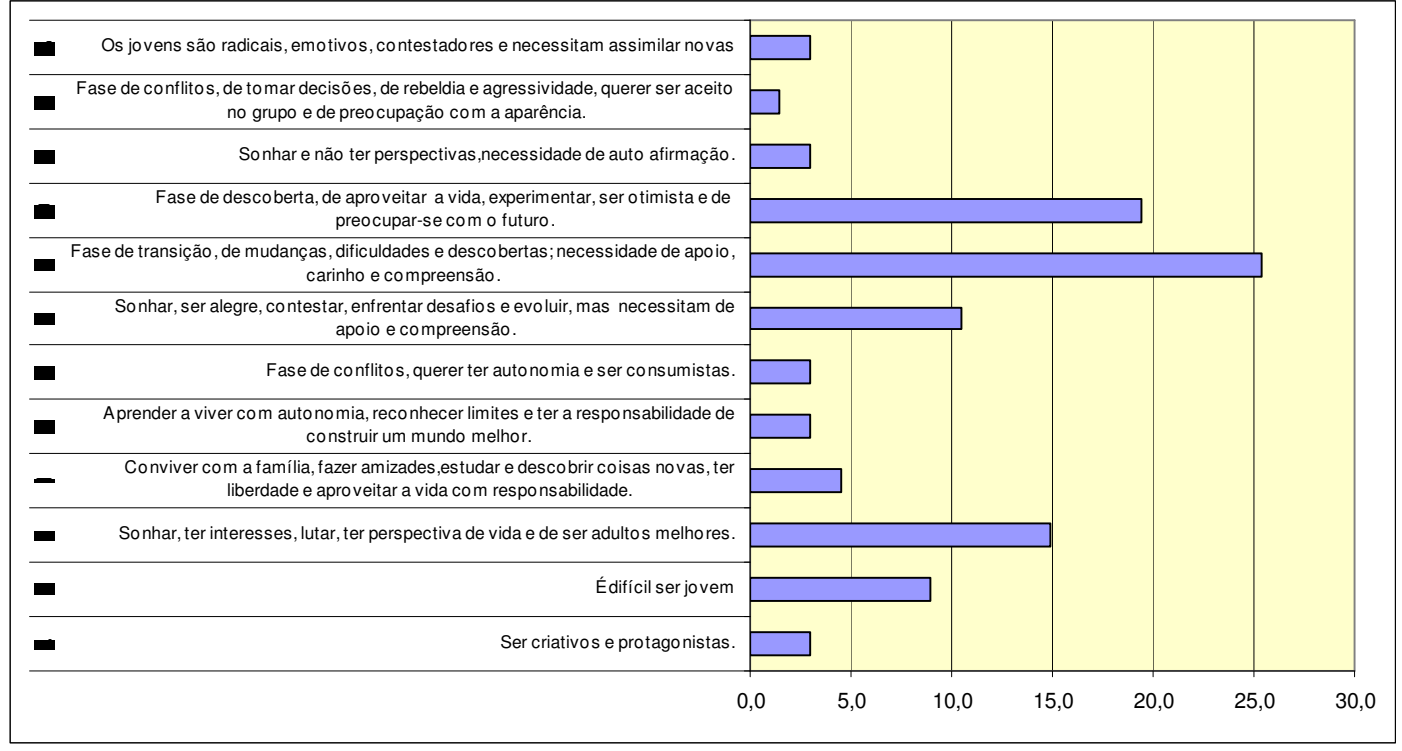

Total de resposta da pergunta: 67 
Para os profissionais da área da educação, ser jovem é predominantemente: Fase de transição, de mudanças, dificuldades e descobertas; necessidade de apoio, carinho e compreensão, com 17 respostas (25,37\%), seguido do discurso: Fase de descoberta, de aproveitar a vida, experimentar, ser otimista e de preocupar-se com o futuro, com 13 respostas $(19,40 \%)$.

Verifica-se, ainda, o discurso: Sonhar, ter interesses, lutar, ter perspectiva de vida e de ser adultos melhores, com dez respostas $(14,93 \%)$ e Sonhar, ser alegre, contestar, enfrentar desafios e evoluir, mas necessitam de apoio e compreensão, com sete respostas (10,45\%). Contrapondo-se, temos a visão de que $\mathbf{E}$ difícil ser jovem, com seis respostas $(8,96 \%)$.

O discurso predominante dos educadores é o da juventude como fase de transição para a idade adulta. Uma fase difícil, marcada por mudanças físicas, emocionais e psicológicas, na qual o jovem tem dificuldade de se integrar na sociedade. Consideram que os jovens necessitam de boa orientação familiar e educacional e que lhes seja indicado o caminho para o seu desenvolvimento: e o que querem na verdade é alguém de pulso firme, que mostre o caminho certo e errado, para aprender a crescer, amadurecer e reconhecer a vida futura. É um ser inseguro, semi-Deus, sabe tudo, mas ao mesmo tempo são muito carinhosos, precisam muito de amor, carinho e muita orientação, como pode ser visto no DSC, Anexo 67 e nos que seguem:

DSC- Fase de transição, de mudanças, dificuldades e descobertas, necessidade de apoio, carinho e compreensão.

É um período legal da vida, em que estão passando da infância para a idade adulta e precisam de apoio e compreensão. É uma fase de extrema mudança, tanto física como emocional e psicológica. É uma fase de procura, de descobertas com o que se passa no mundo, de descobrir suas afinidades, dificuldades e encontrar um caminho certo para a formação do seu caráter e integração na sociedade.

Segundo a minha visão é um período de conflitos, incertezas, escolhas e cobranças. É um período difícil de transição, ora são crianças para algumas coisas, ora têm que ser adultos para outras. Acho que é uma perda de posição, quando crianças, tudo é perdoado, te cobram postura de adulto que ainda não têm. Todos nós já passamos por essa fase de vida, que é uma fase de descoberta do mundo em que vivemos de preocupar-se com o nosso futuro, com o que nos aguarda e com as nossas referências.

Hoje eles têm muita informação, mas não conseguem selecionar o que é bom para a formação deles. A adolescência é muito sofrida porque os problemas da vida adulta estão muito presentes. A dificuldade é que tudo está muito solto, não tem diretrizes claras para se sentirem situados neste contexto sociopolítico. Os adolescentes sofrem muito, faltam informações e falta base familiar. 
É processo mudança, de sonhar com o impossível, acreditar nos ideais. Momento de estar atento às transformações do crescimento. Momento de descobertas e investigações, onde tem que ter a presença de adultos. Se essa fase for bem curtida, irá gerar bons frutos. Passam por um período de amadurecimento, questionando os valores que tinham quando crianças e precisam saber se colocar na sociedade. Precisam de boa orientação familiar e educacional, e o que querem na verdade é alguém de pulso firme, que mostre o caminho certo e errado, para aprender a crescer, amadurecer $e$ reconhecer a vida futura. É um ser inseguro, semi-Deus, sabe tudo, mais ao mesmo tempo são muito carinhosos, precisam muito de amor, carinho e muita orientação..

O segundo discurso mostra a juventude como um momento de descobertas, de liberdade, experimentações e transformações constantes de sonhos e esperanças.

DSC - Fase de descoberta, de aproveitar a vida, experimentar, ser otimista e de preocupar-se com o futuro

É um movimento de descoberta, de transformação, de aproveitar melhor a adolescência, pensar no futuro ou pelo menos começar a pensar no futuro. É tudo de bom! É você achar que a vida é linda e maravilhosa e descobrir um monte de coisa.

É uma coisa muito legal. Muitos acham que podem fazer o que quer, estão livres para namorar e beijar.

É uma fase de mudanças e experimentação, o qual se vai descobrindo a liberdade $e$ as responsabilidades ao mesmo tempo.

É a fase mais bonita e não aproveitam, estão se conhecendo melhor, passam por transformações constantes.O corpo e a cabeça se modificam. É uma fase muito boa, pensamento de crescer ter um futuro.

É a fase da descoberta, de mudanças, de descobrir o mundo e aproveitar a vida. Querem conhecer, saber tudo sobre as novidades e experimentar. Eles não têm medo, são questionadores, têm esperanças e acreditam que podem mudar o mundo.

É aproveitar ao máximo o que a vida tem para oferecer, ter bom humor, ser otimista e planejar o futuro.

Como no discurso anterior, o DSC seguinte mostra que os educadores consideram que os jovens devem viver com intensidade, ter sonhos, mas devem lutar, ter oportunidades, força de vontade e querer mudar. No entanto, no discurso, $o$ adolescente é como um vaso, tem que ser modulado desde pequeno, ensinado a ter objetivos, sonhos e como realizá-lo, verifica-se que o jovem não é visto como um sujeito em desenvolvimento, capaz de adquirir controle sobre a própria vida e ter autonomia. 
DSC - Sonhar, ter interesses, lutar, ter perspectivas de vida e ser adultos melhores.

Os adolescentes têm que sonhar, viver cada dia com intensidade, ser feliz e ter poucas responsabilidades. Os adolescentes têm de ser lutadores, correr atrás dos seus sonhos, não desistir nunca dos seus objetivos e lutar sempre.

Ser jovem é começar desde criança conhecer as coisas boas, aproveitar a infância para quando crescer ter suas perspectivas de poder ser adultos melhores.

Na minha opinião, o jovem tem que ter esperanças, ter incentivo, oportunidades e perspectivas de um futuro melhor. O adolescente é como um vaso, tem que ser modulado desde pequeno, ensinado a ter objetivos, sonhos e como realizá-los.

Ser adolescente é descobrir a vida, os caminhos que ela oferece, é poder ser você mesmo, não ter medo e nem vergonha de errar.É saber perguntar, ter limites e ter respeito pelo próximo.

Hoje adolescente é a maneira de pensar, o jovem tem que sonhar viver aventuras, ter objetivos $e$ nunca desistir de seus sonhos.

Os jovens têm que ter mais oportunidades e força de vontade, querer mudar, ter um futuro melhor.

É um período de descobertas, vontade de superar dificuldades, de mostrar que é capaz..

Observam-se, nos discursos dos educadores, os conflitos vividos pelos jovens para a constituição da subjetividade. A juventude é considerada uma fase de transição, e os jovens necessitam de apoio, referências positivas e oportunidades para seu desenvolvimento.

Segundo os educadores entrevistados, nesse período de transitoriedade, os jovens ora são crianças para algumas coisas, ora têm que ser adultos para outras. Entendem que é uma perda de posição, quando crianças, tudo é perdoado, te cobram postura de adulto que ainda não têm. É momento de estar atento às transformações do crescimento. Nessa fase de transição e descoberta do mundo, inicia-se a preocupação com o futuro; entretanto, os jovens, segundo os educadores, apesar de terem muitas informações, não conseguem selecionar o que é bom para a formação deles. Os jovens passam por um período de amadurecimento, questionando os valores que tinham quando crianças e precisam saber se colocar na sociedade. No caminho para seu desenvolvimento, encontram muitas dificuldades, tudo está muito solto, não têm diretrizes claras para se sentirem situados neste contexto sociopolítico. O sofrimento dos jovens decorre da falta de informações e falta base familiar, além disso, os problemas da vida adulta estão muito presentes. Verifica-se que os educadores não se referem ao papel da escola nesse contexto.

Para os educadores, as dificuldades vivenciadas na juventude são biológicas, emocionais, psicológicas, próprias dessa fase, e estruturais. Os discursos indicam que as famílias têm um papel importante para orientar e dar diretrizes aos 
jovens; no entanto, devido às vulnerabilidades, não conseguem suprir suas necessidades. Referem-se, ainda, à importância das relações sociais estabelecidas e à aceitação nos grupos.

Embora dêem importância à formação dos jovens para que estes possam tomar decisões e fazer escolhas que irão determinar o futuro, os DSCs dos educadores não explicitam propostas da escola nesse sentido. Ressaltam nessa fase as alegrias vividas, o processo de mudanças, as descobertas, os sonhos e ideais, a irreverência, as inovações e a influência do consumo na vida dos jovens. É um momento de desafios, de força, evolução e desenvolvimento físico, psicológico e financeiro. Depositam nos jovens a esperança de um futuro melhor $e$, segundo os educadores, se essa fase for bem curtida, irá gerar bons frutos.

O DSC É difícil ser jovem revela as vulnerabilidades sociais, tais como a violência doméstica, a falta de estrutura familiar, o tráfico, presentes no cotidiano dos jovens, e ainda a falta de perspectivas para o futuro. Este DSC mostra a percepção dos jovens como "problema", atribuindo responsabilidades à desestruturação familiar pelas dificuldades vividas pelos jovens e para o contexto estrutural. No DSC os jovens não são vistos como sujeitos de direitos. Essa concepção sobre a juventude da região dificulta a adoção de propostas educativas para a formação e 0 desenvolvimento dos jovens e para uma cultura de não violência pela escola.

DSC - É difícil ser jovem.

Hoje o ser jovem é muito complicado, pois muitas vezes aprendem e convivem com coisas erradas dentro de casa com os próprios pais, por exemplo, a violência doméstica e tráfico. Crescendo assim os jovens se tornam agressivos e sem perspectivas de vida.

Os jovens querem ser rebeldes, sem limites, o dono da razão, eles só querem saber de ter direitos e, deveres, não. Eles não sonham e não têm objetivos, apenas vivem um dia após o outro.

É um ser aborrescente, têm uma visão de futuro, embora não consigam realizá-lo.

$\mathrm{Na}$ minha época era muito diferente, temos os adolescentes aborrescentes e não aborrescentes, tem uma estrutura familiar ruim com maus exemplos de casa, tentamos orientar os pais; estão se descobrindo agora, o pai não enxerga o problema dos filhos.

São tão difíceis, têm uma opinião que não bate com o adulto, não são entendidos e não entendem os adultos, são cheios de dúvidas e intrigas.

É um ser sem compromisso com pouca responsabilidade, sem iniciativa, sem objetivos, alguns jovens tem falta de estrutura familiar. 
A análise dos discursos construídos a partir dos depoimentos dos educadores sobre o que é ser jovem evidencia as marcas dos desencantos, das incertezas em relação ao futuro, do distanciamento em relação às instituições, da descrença na sua legitimidade e na política formal, traduzidas na falta de perspectivas e na necessidade de os jovens terem esperanças em um futuro melhor.

Ressalta-se, ainda, a necessidade de os jovens construírem referências positivas; entretanto, a escola e a família já não teriam a mesma referência que tiveram para as outras gerações. As opiniões sobre as construções dessas referências mostram as vulnerabilidades, no sentido de fragilidades e obstáculos no desenvolvimento dos jovens no contexto local e macro-estrutural.

Segundo AYRES (2008), a noção de vulnerabilidade é um referencial conceitual que vem sendo desenvolvido e utilizado principalmente no campo da prevenção da aids (MANN; TARANTOLA, 1996; AYRES E et.al., 2006), "mas que, a rigor, cabe para qualquer questão de saúde, especialmente quando se trata de problemas complexos, ou seja, aqueles que envolvem questões físicas, mas também questões psíquicas, comportamentais, sociais, culturais, econômicas" (AYRES, 2009, no prelo).

A noção de vulnerabilidade visa estabelecer uma "síntese conceitual e prática das dimensões sociais, político-institucionais e comportamentais associadas às diferentes suceptibilidades de indivíduos, grupos populacionais e até mesmo nações. (AYRES,1996, p.6).

A vulnerabilidade se volta para o contexto singular dos sujeitos e sua finalidade pode ser descrita como: a compreensão e o fortalecimento da capacidade de resposta de indivíduos, famílias, comunidades (das locais até a global) aos diferentes obstáculos e limitações que estes encontram na busca de seus projetos de felicidade em contextos determinados (AYRES, 2009, no prelo).

Para adequada compreensão da adolescência, é necessário observar a indissociabilidade das dimensões sociais, culturais e psicológicas, já constatada em respeitáveis produções teóricas relacionadas ao tema em questão (AYRES, 2008).

$\mathrm{Na}$ fala dos educadores, evidenciam-se os obstáculos e as fragilidades presentes nessa fase de vida nas dimensões física, psicológica, social e cultural, mas também indicam a possibilidade de mudanças, por meio da educação, aliada à 
importância do apoio e orientação a fim de construir de referências positivas para a formação dos jovens como cidadãos. Apontam ainda a necessidade da presença do Estado, no sentido de garantir os direitos básicos para que os jovens possam concretizar seus projetos de vida, todavia não mencionam o papel da escola para a formação do jovem como sujeito social.

\subsection{ANÁLISE DOS DISCURSOS DO SUJEITO COLETIVO DOS PROFISSIONAIS DA SAÚDE}

São apresentados, neste capítulo, os discursos dos profissionais de saúde sobre o que é ser jovem. Ressalta-se que predominam, entre os profissionais entrevistados, uma visão da juventude como fase de transição para a vida adulta, de descobertas, experiências, formação, desafios e busca da identidade; acreditam que vão mudar o mundo, e a visão da juventude como uma fase difícil.

As demais categorias podem ser verificadas na Figura 6 e constam no anexo (68).

\section{- Fale sobre o que é ser jovem.}

Gráfico 6- Resultados Quantitativos do DSC dos profissionais de saúde - Idéia Central - Fale sobre o que é ser jovem.

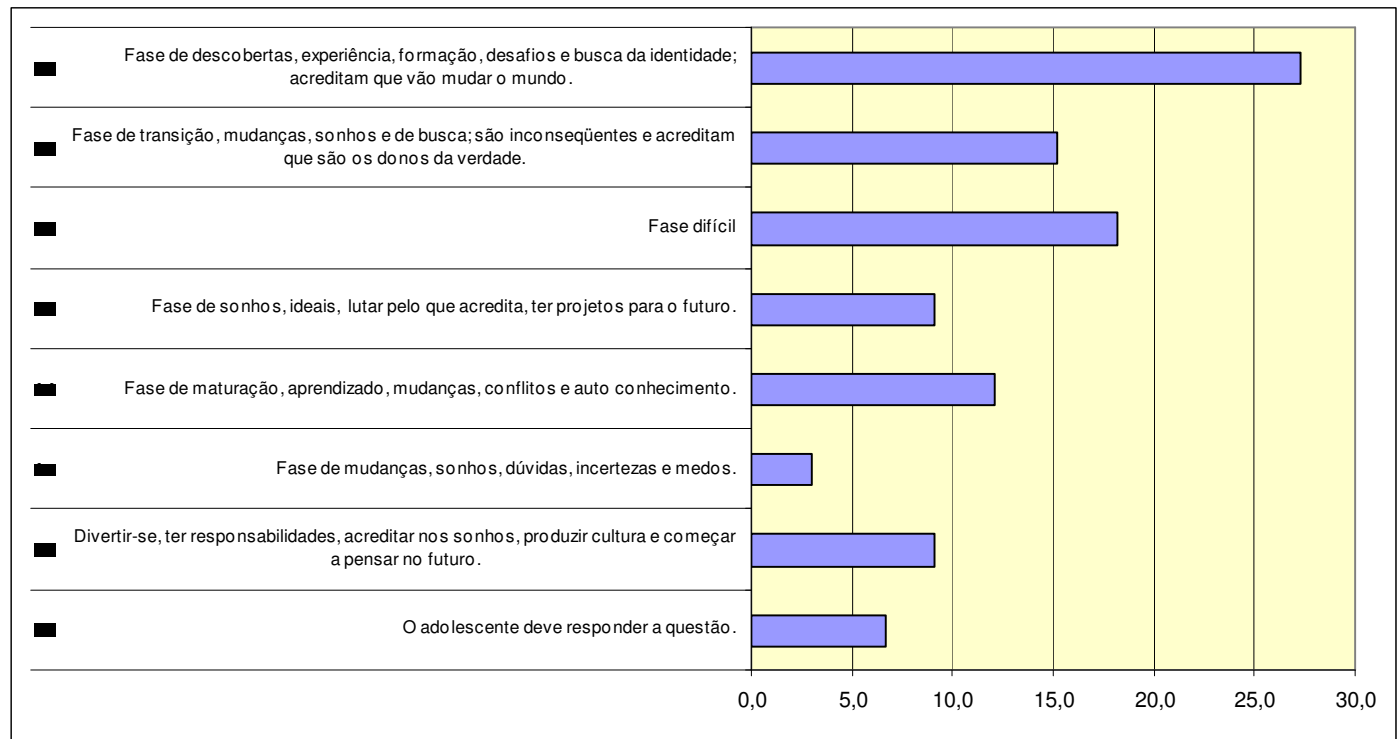

Total de respostas da pergunta: 33 
Apresentamos a seguir o DSC - fase de descobertas, experiências, formação, desafios e busca da identidade; acreditam que vão mudar o mundo, no qual está presente a uma visão "otimista" dos jovens: é um momento de ganhar experiência, de formação e de aproveitar esse momento de crescimento e expandir a energia, que eles têm, de uma forma construtiva. É um momento importante de crescimento pessoal e profissional.

DSC- Fase de descobertas, experiências, formação, desafios e busca da identidade; acreditam que vão mudar o mundo.

"Pra mim é uma delícia. É descobrir o mundo procurando a sua própria identidade. É uma fase de descoberta e de acreditar que vai mudar o mundo. Aí a gente cai na real. Acho bacana. É sonhar, realizar muita coisa e sentir um pouco super homem. Você acredita que pode muito sempre buscando construir alguma coisa.

Ser jovem, adolescente, é não ter medo de nada, acreditar que o mundo não tem perigo e que nada errado vai acontecer com eles. Gostam de desafiar, na minha época era assim.

É não ser mais criança, sem ainda ser um adulto. É começar a enxergar o mundo com um olhar mais desencantado, é sentir inseguro, e não saber exatamente o que é. É ver cair os seus heróis por terra e surgirem outros da forma mais inesperada. É querer mais, do que em qualquer outro momento da vida, amar e ser amado.

Eu vejo que é um momento de ganhar experiência, de formação e de aproveitar esse momento de crescimento e expandir a energia, que eles têm, de uma forma construtiva. É um momento importante de crescimento pessoal e profissional.

Ser adolescente é você buscar algo, que mesmo com muito trabalho, algumas vezes é inatingível. Não porque eles não têm capacidade de buscar, mas porque não depende só dos adolescentes.

É a busca de uma identificação no meio de uma sociedade, e um querer único sem poder se desvincular de um grupo, seguindo os mesmos padrões deste, resumindo, é um conflito geral, fase de transição entre criança e adulto.

Nessa fase as transformações acontecem, assustam e encantam. É uma tomada rápida de decisão. Ser jovem é uma transformação de caráter e a base de sustento, para a definição do seu caráter, para a busca de desafios e conquistas é o lar”.

Contrapondo-se à visão otimista da juventude dos profissionais de saúde entrevistados, há a noção de juventude como uma fase difícil, uma fase de descobertas, dúvidas e inseguranças, sendo difícil também definir as transformações que ocorrem nesta fase. Além disso, revela a visão do jovem no contexto das políticas públicas: é muito difícil, é um segmento isolado de tudo e ninguém direciona o foco para eles. Não há programas para eles. Mostra ainda as vulnerabilidades, a gravidez na adolescência e o acesso à s drogas, como problemas da desestruturação familiar que afeta os jovens nas periferias. 
DSC - Fase difícil.

É uma fase difícil, eles têm que se situar no mundo adulto, não é mais uma criança. Têm atitudes de crianças e querem ser adultos. É uma fase de descobertas, dúvidas e inseguranças. É uma coisa dificil de definir.

É muito difícil, é um segmento isolado de tudo e ninguém direciona o foco para eles. Não há programas para eles. É difícil, todos nós já fomos, para mim é a época onde a gente tem muita energia e na verdade não se dá muita importância para os mais velhos. Acha que sabe tudo. A capacidade de aprendizado está muito fresca, mas precisam de boa família, boa escola, para a rebeldia não fluir.

É cruel, é uma fase de mudanças fisiológicas e precisam de orientação. Será que as mães e os pais destes adolescentes têm orientação sexual e cultural para passar para os filhos? Eles não têm orientação dentro de casa e ficam vulneráveis à gravidez e drogas, por falta de maturidade e de estrutura familiar. Há muitos questionamentos. Acho que é isso, a dificuldade de suportarem e passarem por essa fase com prazer e segurança. É complicado porque têm uma vida pela frente. $E$ uma fase de ter sonhos, achar a identidade, se formar enquanto gente e pensar no futuro. Eles não têm prazer e sonhos, mesmos que frustrados.

Constatamos que os discursos dos profissionais denotam os conflitos que permeiam essa fase da vida e vão ter influência na construção da identidade dos jovens, tais como a noção de transição, a sexualidade, a exaltação do corpo, a influência do grupo, o papel da família, da escola, do trabalho, os projetos para o futuro e a falta de perspectivas.

Nesse sentido, os profissionais questionam o papel das famílias: É cruel, é uma fase de mudanças fisiológicas e precisam de orientação. Será que as mães e os pais destes adolescentes têm orientação sexual e cultural para passar para os filhos? Eles não têm orientação dentro de casa e ficam vulneráveis à gravidez e drogas, por falta de maturidade e de estrutura familiar.

São inúmeras as dificuldades e conflitos vivenciados pelos jovens. Os profissionais entendem que, nessa fase de transição em direção à autonomia da vida adulta, a experiência dos jovens está permeada de contradições. Uma delas, considerada a maior, seria a própria situação juvenil: etapa de vida em que o indivíduo já alcançou as condições físicas e biológicas para assumir certos papéis e tarefas que, no entanto, ainda lhes são negados pela sociedade (FORACCHI,1982, p.26).

Os profissionais caracterizam a juventude como uma situação de "crise da adolescência", desencadeada partir do fenômeno da puberdade, traz consigo os conflitos estreitamente vinculados à questão da sexualidade. Com este enfoque o período de mudanças físicas e hormonais que a caracterizam introduz conflitos e 
transformações, na adolescência, sendo permeado pela necessidade de o jovem assumir uma determinada posição em relação à própria sexualidade, tarefa difícil que freqüentemente é acompanhada de muitas angústias.

A sexualidade é tida como uma dimensão fundamental de todas as etapas da vida de homens e mulheres, envolve práticas e desejos relacionados à satisfação, à afetividade, ao prazer, aos sentimentos, ao exercício da liberdade e à saúde. É uma construção histórica, cultural e social, que se transforma conforme mudam as relações sociais. Na nossa sociedade, a sexualidade foi histórica e culturalmente limitada em suas possibilidades de vivência, devido aos tabus, mitos e preconceitos, interdições e relações de poder (MS, 2006 p.13).

A sexualidade para os jovens é um campo de descobertas, experimentações e vivências de liberdade, como também de construção de capacidades para tomada de decisões, de escolhas, de responsabilidades e de afirmação de identidades, tanto pessoais como políticas, o que explica as inseguranças dos jovens referidas pelos profissionais.

Afirmar-se sexualmente é motivo de insegurança, temores e medo, sentimentos nem sempre manifestados claramente, que com toda certeza mobilizam e ocupam grande parte da vida dos jovens e os deixam vulneráveis. Nesse campo a busca por autonomia de projetos e práticas é exercida de forma singular e com urgência própria da juventude. A falta de reconhecimento social dos adolescentes e jovens como pessoas sexuadas, livres e autônomas, submetem-nos a situações de vulnerabilidade, no plano pessoal, social e institucional e a diversas interdições pessoais (MS, 2006).

Conforme mostram os discursos, a juventude é uma fase de solidão, incertezas e instabilidades, sendo muito difícil para o jovem pensar no que serão quando adultos. Desejam uma aparência física diferente, rejeitam seus traços naturais, valorizam o corpo, o físico, a aparência., conforme a concepção de sujeito ideal proposta socialmente. A passagem do jovem para a condição de adulto é crítica na sociedade moderna, em razão da complexidade das formas que assumem a organização social, a variedade de alternativas de vida e a conseqüente incerteza quanto ao próprio destino pessoal. 
Essas questões são decorrentes das transformações ocorridas na Revolução Industrial. Conforme HOBSBAWM (1997), analisando as transformações ocorridas na revolução cultural e fim do século XX, destaca o "triunfo do indivíduo sobre a sociedade, ou melhor, o rompimento dos fios que antes ligavam os seres humanos em texturas sociais", e a insegurança diante dessa sociedade anônima, onde "a incerteza e a imprevisibilidade eram iminentes" ( HOBSBAWM 1997, p.328).

Concluindo, neste capítulo foram apresentados os discursos dos jovens estudantes e não estudantes, dos pais dos jovens, lideranças, educadores e profissionais de saúde. Verificou-se que predominam entre os entrevistados a percepção da juventude como uma fase de transição, marcada pelas dificuldades físicas, sociais, culturais e psicológicas.

Os jovens, assim como seus pais, valorizam a família, os estudos e o trabalho, e consideram que a juventude é um momento de se preparar para o futuro.

As lideranças enfatizam que os jovens são sujeitos de direitos e responsabilizam o Estado na garantia desses direitos. Os educadores, os profissionais de saúde e as lideranças ressaltam as vulnerabilidades que afetam os jovens nas regiões de estudo, tais como: a violência, acesso às drogas, o tráfico, a gravidez precoce, o desemprego e a falta de perspectivas, de oportunidades e de políticas públicas. Ressaltam a desestruturação familiar e o contexto social como obstáculos para o desenvolvimento dos jovens. Os educadores citam a importância da educação para o desenvolvimento dos jovens, contudo não apresentam propostas do ponto de vista do ensino. As lideranças das entidades sociais das regiões, por sua vez, destacam a importância do Estado, mas também não se colocam como coresponsáveis no desenvolvimento dos jovens. Nos discursos dos entrevistados estão presentes ainda a visão "otimista" e "pessimista" da juventude. 


\section{OS TERRITÓRIOS: HISTÓRIA, CONTEXTO, INTERAÇÕES E PERCEPÇÕES DOS ATORES}

O Grajaú e o Jardim Ângela fazem parte dos 96 distritos administrativos que constituem o município de São Paulo. Localizados na região sul do município, esses distritos estão incorporados desde agosto de 2002 às subprefeituras da Capela do Socorro e do M'Boi Mirim, respectivamente. As duas regiões têm em comum vários aspectos. Ambos os distritos estão em áreas de proteção ambiental: o Grajaú limitase com a Represa Billings e o Jardim Ângela com a Represa de Guarapiranga. A primeira etapa de ocupação das duas regiões foi marcada pela construção da Represa de Guarapiranga e a criação da linha de bondes ligando São Paulo a Santo Amaro.

A partir da década de 1960 iniciou-se um processo de ocupação nas regiões, associado à industrialização da região de Santo Amaro, com o desmembramento de antigos sítios e chácaras de ambas as regiões e a criação de bairros e vilas caracterizados por loteamentos irregulares, desprovidos de infra-estrutura, o que permanece, em muitas áreas, até os dias de hoje.

Neste capítulo são apresentados os aspectos históricos das regiões da Capela do Socorro e de M'Boi Mirim, a caracterização dos distritos de estudo, com o objetivo de mostrar as semelhanças e diferenças existentes.

Como veremos a seguir, os dois distritos têm crescimento demográfico elevado e predominância de população de baixa renda, e é expressivo o percentual de população migrante de outras regiões do país. Os índices de violência que, apesar da redução registrada nos anos mais recentes, são ainda elevados em relação ao restante do município.

\subsection{ASPECTOS HISTÓRICOS DA REGIÃO DA CAPELA DO SOCORRO}

Conforme FERNANDEZ e LICO (2006), a história da ocupação da região da Capela do Socorro, a qual pertence o distrito do Grajaú, está estreitamente relacionada à expansão e estruturação urbanas da Administração Regional de Santo Amaro, à qual esteve administrativamente ligada até 1985. 
A região, em épocas anteriores, foi habitada pelos índios tupis, que ocupavam também vários pontos da região Sul do Brasil, além do litoral. Já no século XX, os guaranis, subgrupo tupi, no curso de seu processo migratório, chegaram a Parelheiros - distrito com o qual a Capela do Socorro tem seu limite mais ao sul - e lá se fixaram. Remanescentes desse núcleo são as duas aldeias que ainda existem na porção meridional da cidade de São Paulo - a de Krucutu e a do Morro da Saudade que reúnem cerca de 600 indígenas.

O interesse pela região da Capela do Socorro desponta nas primeiras décadas do século XX, após a construção das barragens da Light: em 1907, a do rio Guarapiranga, dando origem à represa que ocupa área de $33,9 \mathrm{~km}^{2}$, com a finalidade principal de regularizar a vazão do rio Tietê e garantir a geração de energia na Usina Edgard de Souza em Santana do Parnaíba; e a do Rio Grande, construída após a grande seca de 1924, que deu origem à represa Billings, ocupando área de $130 \mathrm{~m}^{2}$ entre São Paulo e São Bernardo do Campo.

As represas criaram um potencial de lazer até então desconhecido na região, ensejando intensa especulação imobiliária em torno de loteamentos para construção de equipamentos recreativos. Chácaras de recreio, clubes de campo, clubes náuticos e balneários passaram a caracterizar extensas áreas dos arredores das represas. A construção da auto-estrada Washington Luís em 1928, com 16 km, ligou o Ibirapuera a Interlagos, via Santo Amaro e Socorro, e foi, posteriormente, completada com a avenida Interlagos, impulsionando ainda mais o desenvolvimento das atividades recreativas da região.

Alguns loteamentos residenciais de padrão médio surgiram nessa época, na porção norte da Capela do Socorro, entre os quais o maior era Vila Friburgo. $\mathrm{Na}$ década de 1930, uma importante construtora e imobiliária, a "Aesa - Auto Estradas S.A.", criou o loteamento denominado "Interlagos - Balneário Satélite de São Paulo", realizando no local grandes investimentos para criar infra-estrutura urbana e melhorias rodoviárias.

O objetivo era assentar, de frente para a Represa de Guarapiranga, um bairro residencial de alto padrão para atender às camadas de maior poder aquisitivo. No entanto, o empreendimento não evoluiu; anos depois, apenas algumas dezenas de famílias haviam se instalado, em meio a quarteirões completamente vazios. Muitas 
casas construídas para fins residenciais acabaram sendo ocupadas por restaurantes. Naquela época, com exceção de uma ou outra chácara que serviam de residência permanente de famílias de alta renda, a região das represas não atraiu essa camada da população, a não ser para fins recreativos. Hoje a área está ocupada por residências, ainda que na orla da represa se tenha mantido e desenvolvido a ocupação por desenvolvimentos comerciais.

Até a década de 1940, Capela do Socorro era ainda pouco ocupada. No entanto, esses anos marcam o início do processo de abertura de loteamentos industriais em Santo Amaro que, pela proximidade, começaram a afetar a dinâmica urbana da região de Capela. Os trabalhadores das empresas de Santo Amaro encontram, em Capela, local mais acessível para morar.

Em um meio essencialmente rural, desenvolveram-se vários povoamentos ao longo de estradas locais ou nos entroncamentos de estradas, na medida em que passaram a ser servidas por linhas de ônibus. Entre esses núcleos, destacava-se, pela sua importância, Rio Bonito, situado no entroncamento da então estrada estadual Engenheiro Marsilac com a Estrada do Clube de Campo. Mais ao sul, destacava-se a Vila São José, onde já existia um bairro rural de mesmo nome. Esses dois povoados se transformaram, posteriormente, em pólos em torno dos quais surgiram densos subúrbios.

Cidade Dutra é outro exemplo de bairro popular que surgiu na década de 1940. Os bairros citados haviam se formado em um desenvolvimento mais espontâneo da população em torno de entroncamentos de estradas ou de vilas rurais preexistentes, que passaram a ser servidas por linhas de ônibus. Cidade Dutra, ao contrário, foi planejada e construída pela empresa Auto-Estrada S.A., com financiamento do Instituto de Aposentadorias e Pensões dos Serviços de Transporte (IAPST), com o objetivo de atender a demanda habitacional dos trabalhadores ligados a esse Instituto. Aquela empresa realizou não só o loteamento, mas também a construção das casas. Tratava-se de um grande conjunto residencial (com cerca de 500 unidades inicialmente) caracterizado por grande homogeneidade no tamanho e estilo das casas, dotado de infra-estrutura urbana, como ruas pavimentadas, iluminação pública, água e esgoto, além de um pequeno centro comercial. Na época em que foi construída, Cidade Dutra encontrava-se completamente isolada, mas 
representou uma experiência pioneira na região. Logo foram estabelecidas linhas de ônibus para atender ao novo bairro que passou a exercer função polarizadora no desenvolvimento de seus arredores. ${ }^{1}$

Outros bairros continuavam a se formar como resultado de iniciativas imobiliárias, como o loteamento de glebas quase sempre sem preocupações urbanísticas ou outros critérios além da obtenção de lucros. Característica comum a todos foi o fato de que a linha de ônibus surgiu em decorrência do núcleo já loteado e ocupado. As estradas percorridas pelos ônibus funcionaram como eixos, gerando pequenas aglomerações em torno dos pontos de parada ou no terminal da linha. Nesses locais instalaram-se estabelecimentos comerciais e de serviços, geralmente modestos, para atender as necessidades locais.

Os pequenos centros de atividades terciárias ao longo das vias principais foram crescendo à medida que os bairros se adensaram e muitos serviram como pólos em torno dos quais surgiram novos bairros.

Nas décadas de 1950 e 1960, o Estado de São Paulo viveu intenso processo de expansão industrial, com importantes alterações no padrão de localização da indústria, que foi se deslocando das regiões centrais para as mais periféricas. $\mathrm{Na}$ cidade de São Paulo, esse processo teve, como um de seus aspectos, a ampliação do parque industrial de Santo Amaro, que se consolidou como um dos mais importantes pólos de emprego industrial da região metropolitana. A disponibilidade de áreas, as facilidades de transporte, particularmente com a construção do sistema de marginais do rio Pinheiros e a abundância de água e energia, contribuíram para atrair grande número de estabelecimentos industriais dos setores mais modernos da indústria de transformação, que se instalaram ao longo do canal de Jurubatuba, chegando até as proximidades do Largo do Socorro.

O desenvolvimento industrial exerceu grande influência em Capela do Socorro. A região passou a acomodar parte do crescimento urbano da cidade, uma vez que sua área rural era imensa e relativamente próxima do centro industrial de Jurubatuba e dos dinâmicos centros de comércio e serviços localizados ao sul e sudoeste da região metropolitana. Para Capela afluíram significativos segmentos da

\footnotetext{
${ }^{1}$ Langembuch, Jurgen R. A Estruturação da Grande São Paulo, Fundação IBGE, Rio de Janeiro, 1971.
} 
população trabalhadora que buscavam áreas ainda não consolidadas e com disponibilidade de terra urbana a baixo custo.

Os novos bairros que então surgiram acompanharam o padrão periférico de expansão urbana que caracterizou o crescimento de São Paulo particularmente na década de 1970. Os arruamentos penetraram em áreas onde o solo é mais vulnerável à erosão e com altas declividades que as tornam inadequadas à urbanização.

Sem dispor de infra-estrutura urbana, de equipamentos sociais e distantes do transporte coletivo, grande número de trabalhadores construíram suas casas em lotes muitas vezes ilegais e comprados através de longos financiamentos.

O crescimento populacional é um importante indicador das transformações ocorridas na região: de 36.510 habitantes em 1960, Capela do Socorro passou a 317.179 em 1980; dados do Censo 2000 do IBGE apontam que a região contava, naquele momento, com 675.162 habitantes. Isso representa um incremento populacional de mais de $768 \%$ nos primeiros 20 anos e novo crescimento de $113 \%$ nos últimos 20 anos. $^{2}$

A partir de 1976 a ocupação da região de Capela do Socorro passou a ser regulamentada pela Lei de Proteção dos Mananciais $^{3}$ e pela legislação de zoneamento industrial ${ }^{4}$. Esta última obteve certo êxito no que se refere às restrições à implantação de novas indústrias na região e ao controle de expansão das já existentes. No entanto, a legislação relativa aos mananciais foi insuficiente para conter o avanço da urbanização e a degradação ambiental.

A lei dos mananciais estabeleceu baixos limites de densidade para a ocupação do solo e dificultou o licenciamento de empreendimentos na área, mesmo quando adequado às normas legais. Praticamente excluídos do mercado imobiliário formal, os preços dos terrenos se tornaram extremamente baixos. A depreciação do valor da terra, aliada a outros fatores, como inadequada política habitacional, baixa renda dos trabalhadores, proximidade de grande concentração de empregos, dificuldades de fiscalização e certa conivência por parte dos órgãos públicos, tiveram como efeito a

\footnotetext{
${ }^{2}$ Estes dados incluem os distritos de Parelheiros e Marsilac, que foram, em 2002, desmembrados da Capela do Socorro, dando origem à Subprefeitura de Parelheiros. Em 2000, segundo o Censo do IBGE, a população desses dois distritos somava 111.240 moradores.

${ }^{3}$ Lei n.o $1172 / 76$.

${ }^{4}$ Lei n. ${ }^{\circ} 1817$ de 27/10/78.
} 
expansão desenfreada dos loteamentos clandestinos e de favelas, localizadas em grande parte ao longo dos córregos contribuintes das represas.

Esse tipo de urbanização teve impacto negativo nas áreas de proteção ambiental, particularmente sobre a represa do Guarapiranga, que tem papel tão importante no abastecimento de água do município de São Paulo. Essa represa está sendo poluída pelos despejos dos dejetos e águas servidas dos aglomerados urbanos que se localizam nas proximidades, que não são servidos por rede de esgoto nem são atendidos pela coleta de lixo.

Diante desse quadro de degradação ambiental, a Prefeitura da cidade de São Paulo desencadeou em 2007 um conjunto de medidas para controlar, recuperar e urbanizar os mananciais Guarapiranga, Billings e seu entorno. A operação tem Comitês Gestores constituídos nas Subprefeituras de Parelheiros, Capela do Socorro, M'Boi Mirim e Cidade Ademar, com participação de vários órgãos estaduais e municipais, responsáveis pelo planejamento local e execução. Trata-se de um trabalho que prevê uma série de ações integradas para implementar medidas de controle de ocupação e expansão irregular.

Além da Operação Defesa das Águas que ocorre na região, a subprefeitura da Capela do Socorro tem como proposta para 2008 implantar núcleos de reurbanização na região do Grajaú em parceria com outros órgãos da administração pública.

\subsection{ASPECTOS HISTÓRICOS DA REGIÃO DE M’BOI MIRIM}

M’Boi Mirim, que na língua indígena significa rio das cobras pequenas, teve seu primeiro processo de ocupação em 1607. Nessa época, foram instalados, à beira do rio Pinheiros, próximo à aldeia indígena do M'Boi Mirim, o Engenho de Nossa Senhora da Assunção de Ibirapuera e uma sociedade para extração de minério de ferro, a primeira da América do Sul. A área onde hoje fica o Jardim São Luiz era então conhecida como Ibirapuera e funcionava como uma espécie de posto avançado, para identificar e retardar prováveis ataques de índios ao povoado principal, fundado pelos jesuítas no Páteo do Colégio.

A experiência com a extração de minério de ferro durou cerca de 20 anos e depois foi abandonada, pois o material produzido não foi considerado de boa qualidade. Após essa fase, a área da antiga aldeia dos índios Guaianases ficou 
praticamente esquecida, servindo apenas como ponto de passagem para os viajantes em direção ao Embu e Itapecerica da Serra. Em 1829 ocorreu o segundo processo de ocupação da região, com a chegada de um grupo de imigrantes alemães, trazidos por D. Pedro I, para colonizar as terras. Três anos depois a região de Santo Amaro, que incluía a antiga aldeia do M'Boi Mirim, foi elevada à categoria de município. Em 1886 foi inaugurada a primeira ligação de bondes movidos a vapor entre São Paulo e Santo Amaro devido, em grande parte, à produção de batata, marmelada, farinha de mandioca, milho e carne, consumidos em São Paulo, e também madeira, areia e pedras, utilizadas nas construções que vinham do no novo município.

No início do século XX, a The São Paulo Tramway, Light \& Power represou o rio Guarapiranga, afluente do Rio Pinheiros, com a finalidade de regularizar a vazão do Tietê nos meses de seca. A existência de transporte regular nas proximidades colaborou com a escolha do local para construção da represa Guarapiranga. Durante o período de estiagem, as águas do Guarapiranga deveriam ser represadas e descarregadas no Rio Pinheiros para, assim, alimentar as turbinas da Usina de Parnaíba. Com isso a região passou a atrair outras pessoas, como alemães e italianos que vinham nos finais de semana para a região praticar caça, pesca e esportes aquáticos. A área onde hoje fica o Jardim Ângela ficou conhecida como a Riviera Paulista, devido à beleza das margens da represa.

A extinção do município de Santo Amaro ocorreu em 1934 com a inauguração do Aeroporto de Congonhas, por determinação do governo do Estado.

Foi por volta da década de 1950 que se iniciou o processo de degradação da região de M'Boi Mirim. Esse processo começou com o desmembramento dos antigos sítios e chácaras em lotes. No auge do processo industrial, surgiram diversas vilas na zona sul, que em sua maioria eram moradias de operários que chegavam de vários estados e do interior paulista para trabalhar nas fábricas instalando-se em Santo Amaro. Eles foram chegando lentamente e, a partir do fim da década de 1960, ocorreu a grande explosão, com a ocupação predatória e desordenada, inclusive em áreas de preservação, como na região dos mananciais. Depois, com o fim do chamado "milagre brasileiro", as condições de vida passaram a se deteriorar, e a região passou a abrigar principalmente trabalhadores desempregados e pessoas 
"expulsas" de outros bairros pelos altos preços dos aluguéis, muitos deles vivendo em condições precárias, sem água, luz ou saneamento.

Em 2007 teve início na região a Operação Defesa das Águas, com um conjunto de medidas para controlar, recuperar e urbanizar os mananciais Guarapiranga, Billings e seu entorno.

A região, nesse período, também teve um desenvolvimento positivo. Em setembro de 1974, ganhou o Parque Municipal Guarapiranga, com projeto elaborado pelo escritório Burle Marx e Cia. Posteriormente, em 1977, foi inaugurado o Centro Empresarial de São Paulo, localizado no Jardim São Luiz e, em 2008, o Hospital Municipal do M'Boi Mirim.

\subsection{CARACTERIZAÇÃO DOS DISRITOS}

\section{- Localização}

O distrito do Grajaú é um dos três distritos administrativos pertencentes à subprefeitura da Capela do Socorro. Esta subprefeitura compreende ainda os distritos do Socorro e Cidade Dutra. O distrito de Grajaú, com uma área de $92 \mathrm{~km}^{2}$, limita-se ao sul e a oeste com o distrito de Parelheiros, ao norte com o distrito de Cidade Dutra e a leste com a Represa de Guarapiranga.

O distrito administrativo do Jardim Ângela pertence à subprefeitura de M’Boi Mirim. Faz parte ainda dessa subprefeitura o distrito do Jardim São Luis. O distrito de Jardim Ângela, com uma área de $37,4 \mathrm{~km}^{2}$, limita-se ao sul com o distrito de Parelheiros, a leste com a Represa de Guarapiranga, ao norte com os distritos de Capão Redondo e Jardim São Luís e a oeste com o município de Itapecerica da Serra. 
Figura 7 - Município de São Paulo e as subprefeituras

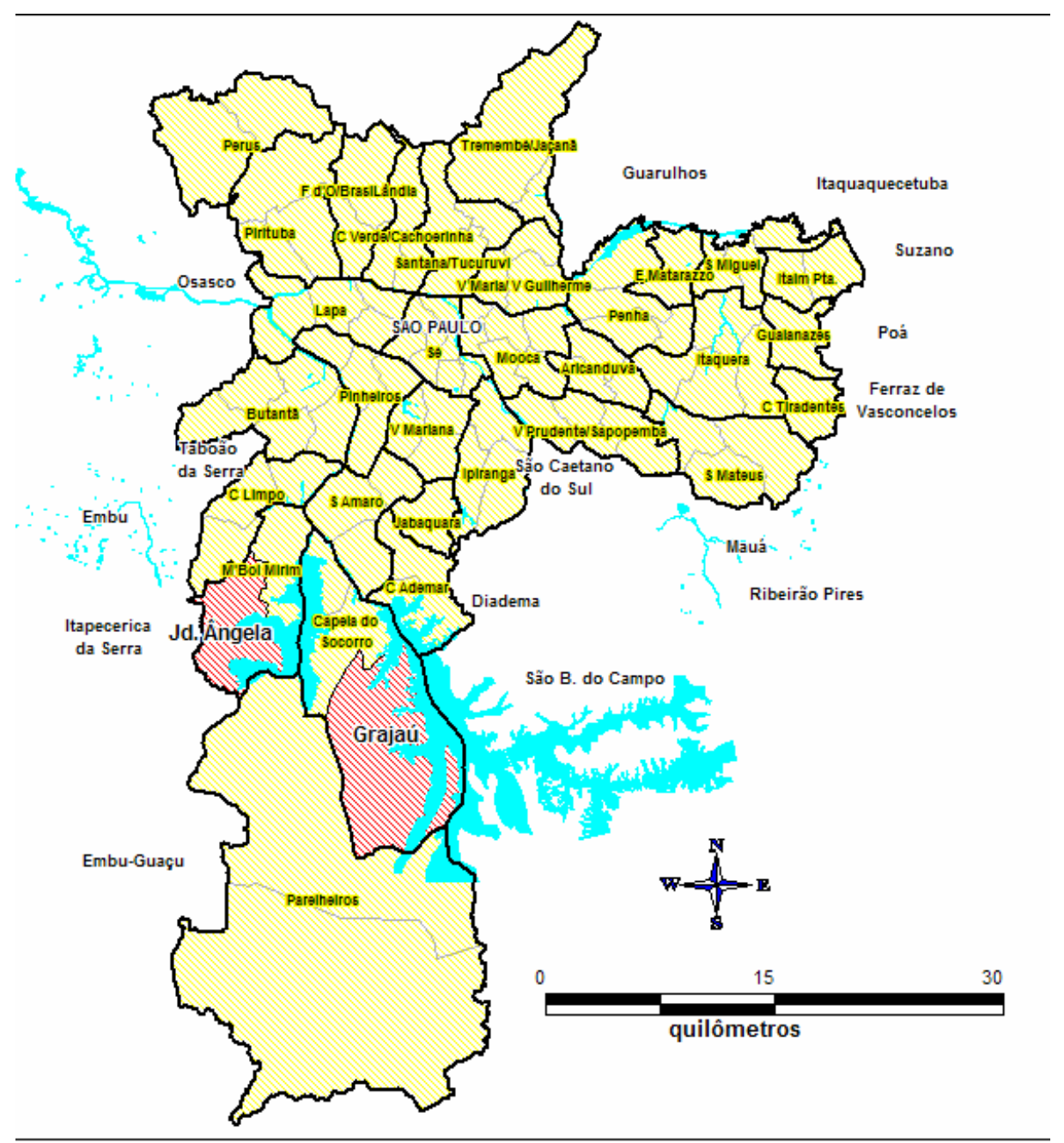

Fonte: Prefeitura Municipal de São Paulo 


\section{O PERFIL DEMOGRÁFICO}

- População residente e a taxa de crescimento demográfico

Segundo dados da Fundação Seade e do IBGE, a população residente no município de São Paulo em 2007, conforme Tabela 5, era de 10.834.244 pessoas. Comparada com a população residente de 1991, apresentou um crescimento anual no período considerado de $0,75 \%$.

O crescimento populacional do distrito de Jardim Ângela, situado na subprefeitura de M'Boi Mirim, no período entre 1991 e 2007, foi de 2,88\% contra $2,11 \%$ da subprefeitura a que está vinculado, correspondendo, em 2007, a populações de 279.975 pessoas no distrito e 532.313 pessoas na subprefeitura. O contingente populacional da subprefeitura de M'Boi Mirim corresponde a 4,9\% da população estimada do município, e o distrito do Jardim Ângela participa com 53\% do total da população da subprefeitura.

O crescimento populacional do distrito do Grajaú, situado na subprefeitura de Capela do Socorro, no período considerado, foi de 4,99\% contra 3,08\% da subprefeitura a que se vincula, correspondendo, em 2007, a populações de 420.880 pessoas no distrito e 656.695 pessoas na subprefeitura. O contingente populacional da subprefeitura de Capela do Socorro corresponde a $6,1 \%$ da população estimada do município, e o distrito do Grajaú participa com $64 \%$ do total da população da subprefeitura.

É importante salientar as fortes taxas de crescimento demográfico apresentadas pelas as áreas de estudo (distrito e subprefeituras), comparativamente com as do município de São Paulo, indicando que o processo de ocupação ainda se mantém presente e forte, constituindo um dos eixos dinâmicos de crescimento demográfico do município. 
Tabela 5 - População residente e estimada, participação percentual no total do município e taxa geométrica de crescimento anual entre 1991 e 2007, subprefeituras e distritos de estudo.

\begin{tabular}{|c|c|c|c|c|}
\hline \multirow{2}{*}{ Território } & \multicolumn{2}{|c|}{ Ano } & \multirow{2}{*}{$\%$} & \multirow{2}{*}{$\begin{array}{c}\text { TCA } \\
(1991-2007)\end{array}$} \\
\hline & 1991 & 2007 & & \\
\hline Município de São Paulo & 9.610 .659 & 10.834 .244 & 100 & 0,752 \\
\hline Subprefeitura Capela do Socorro & 404.276 & 656.695 & 6,1 & 3,078 \\
\hline Grajaú & 193.042 & 420.880 & 3,9 & 4,992 \\
\hline Subprefeitura M $^{\prime}$ Boi Mirim & 381.250 & 532.313 & 4,9 & 2,108 \\
\hline Jardim Ângela & 177.717 & 279.795 & 2,6 & 2,877 \\
\hline
\end{tabular}

Fonte: Prefeitura Municipal de São Paulo - Pro - AIM

- A distribuição da população por sexo

Conforme a Tabela 6, a distribuição percentual da população por sexo no município de São Paulo é de 52,4\% para a população de sexo feminino e 47,6\% para a população masculina. Esses valores indicam uma razão de masculinidade de 0,90, ou seja, para cada mil mulheres residentes, temos 900 homens. Nos distritos de estudo, a proporção de população feminina é de 50,1\% e 50,3\% para Jardim Ângela e Grajaú, respectivamente, correspondendo, na proporção de mil mulheres residentes a 969 e 964 homens, respectivamente.

Tabela 6 - Total da população residente estimada e distribuição percentual por sexo, segundo município, subprefeitura e distritos de estudo em 2007.

\begin{tabular}{|c|c|c|c|c|c|c|}
\hline \multirow{2}{*}{ Território } & \multicolumn{4}{|c|}{ Sexo } & \multirow{2}{*}{ Total } & \multirow{2}{*}{$\%$} \\
\hline & Masculino & $\%$ & Feminino & $\%$ & & \\
\hline Município de São Paulo & 5.159 .366 & 47,6 & 5.674 .878 & 52,4 & 10.834 .244 & 100 \\
\hline Subprefeitura Capela do Socorro & 322.295 & 49,1 & 334.400 & 50,9 & 656.695 & 100 \\
\hline Grajaú & 209.264 & 49,7 & 211.616 & 50,3 & 420.880 & 100 \\
\hline Subprefeitura M`Boi Mirim & 262.777 & 49,4 & 269.536 & 50,6 & 532.313 & 100 \\
\hline Jardim Ângela & 139.490 & 49,9 & 140.305 & 50,1 & 279.795 & 100 \\
\hline
\end{tabular}

Fonte: Prefeitura Municipal de São Paulo - Pro - AIM 
- A distribuição da população por idade

A Tabela 7 indica que a população dos distritos de estudo (Jardim Ângela e Grajaú) tem estruturas populacionais semelhantes, com forte presença de população jovem (até 19 anos) e menor participação das populações idosas (acima de 60 anos). Esse perfil populacional é diferente da média do município, em que essas populações -jovens e idosas - têm participação menos acentuada na faixa de menor idade e maior na outra. Quando comparada a proporção de população até 19 anos nos distritos com as do município de São Paulo, verifica-se que esse contingente populacional representa 39,6\% da população total nos distritos de Grajaú e Jardim Ângela contra $31,7 \%$ para o total do município.

Tabela 7 - Distribuição da população estimada por faixa de idade e sexo, segundo distritos e município de São Paulo em 2007.

\begin{tabular}{|c|c|c|c|c|c|c|c|c|c|c|c|c|}
\hline \multirow{3}{*}{$\begin{array}{l}\text { Faixa de idade } \\
\text { (anos) }\end{array}$} & \multicolumn{8}{|c|}{ Distritos } & \multirow{2}{*}{\multicolumn{4}{|c|}{$\begin{array}{l}\text { Município } \\
\text { São Paulo }\end{array}$}} \\
\hline & \multicolumn{4}{|c|}{ Grajaú } & \multicolumn{4}{|c|}{ Jardim Ângela } & & & & \\
\hline & Homens & Mulheres & Total & $\%$ & Homens & Mulheres & Total & $\%$ & Homens & Mulheres & Total & $\%$ \\
\hline 0 a 4 & 23.825 & 22.529 & 46.354 & 11,0 & 16.294 & 15.107 & 31.401 & 11,2 & 460.072 & 439.577 & 899.649 & $\overline{8,3}$ \\
\hline 5 a 9 & 22.864 & 22.020 & 44.884 & 10,7 & 15.317 & 14.440 & 29.757 & 10,6 & 454.119 & 437.642 & 891.761 & 8,2 \\
\hline 10 a 14 & 19.500 & 18.683 & 38.183 & 9,1 & 12.825 & 12.407 & 25.232 & 9,0 & 417.131 & 405.659 & 822.790 & 7,6 \\
\hline 15 a 19 & 18.392 & 18.609 & 37.001 & 8,8 & 11.994 & 12.290 & 24.284 & 8,7 & 414.313 & 409.280 & 823.593 & 7,6 \\
\hline 20 a 29 & 38.910 & 40.129 & 79.039 & 18,8 & 26.774 & 27.386 & 54.160 & 19,4 & 888.773 & 934.796 & 1.823 .569 & 16,8 \\
\hline 30 a 39 & 35.250 & 36.522 & 71.772 & 17,1 & 23.336 & 24.014 & 47.350 & 16,9 & 836.366 & 918.964 & 1.755 .330 & 16,2 \\
\hline 40 a 49 & 26.520 & 27.132 & 53.652 & 12,7 & 17.101 & 17.258 & 34.359 & 12,3 & 712.866 & 818.998 & 1.531 .864 & 14,1 \\
\hline 50 a 59 & 15.923 & 15.731 & 31.654 & 7,5 & 10.292 & 10.583 & 20.875 & 7,5 & 507.516 & 616.633 & 1.124 .149 & 10,4 \\
\hline 60 a 69 & 5.615 & 6.502 & 12.117 & 2,9 & 3.908 & 4.346 & 8.254 & 3,0 & 281.031 & 370.734 & 651.765 & 6,0 \\
\hline 70 e mais & 2.465 & 3.759 & 6.224 & 1,5 & 1.649 & 2.474 & 4.123 & 1,5 & 187.179 & 322.595 & 509.774 & 4,7 \\
\hline Total & 209.264 & 211.616 & 420.880 & 100 & 139.490 & 140.305 & 279.795 & 100 & 5.159 .366 & 5.674 .878 & 10.834 .244 & $\overline{100}$ \\
\hline
\end{tabular}

Fonte: Prefeitura Municipal de São Paulo - Pro - AIM

\section{CONDIÇÕES SOCIOECONÔMICAS E VULNERABILIDADE SOCIAL}

\section{- A renda domiciliar}

A Figura 8 mostra a distribuição percentual dos domicílios, segundo a renda mensal domiciliar em faixas de salários mínimos para São Paulo e para os distritos de Jardim Ângela e Grajaú. Conforme indica a figura, os domicílios com até três e entre três e cinco salários mínimos representam, respectivamente, $60,3 \%$ e 58,8\% do total de domicílios do Jardim Ângela e Grajaú contra 37,7\% do total para o município de São Paulo. Nas faixas superiores (10 a 20, e 20 e mais) essa proporção 
é de 11,9\% e 13,0\% para Jardim Ângela e Grajaú, respectivamente, e 36,3\% para o município, o que possibilita afirmar que esses distritos têm uma condição de renda muito mais baixa que a do município de São Paulo, quando considerado em sua totalidade.

Figura 8 - Distribuição percentual dos domicílios por faixa de renda mensal em salários mínimos (1), segundo distritos e município de São Paulo (MSP) - 2000.

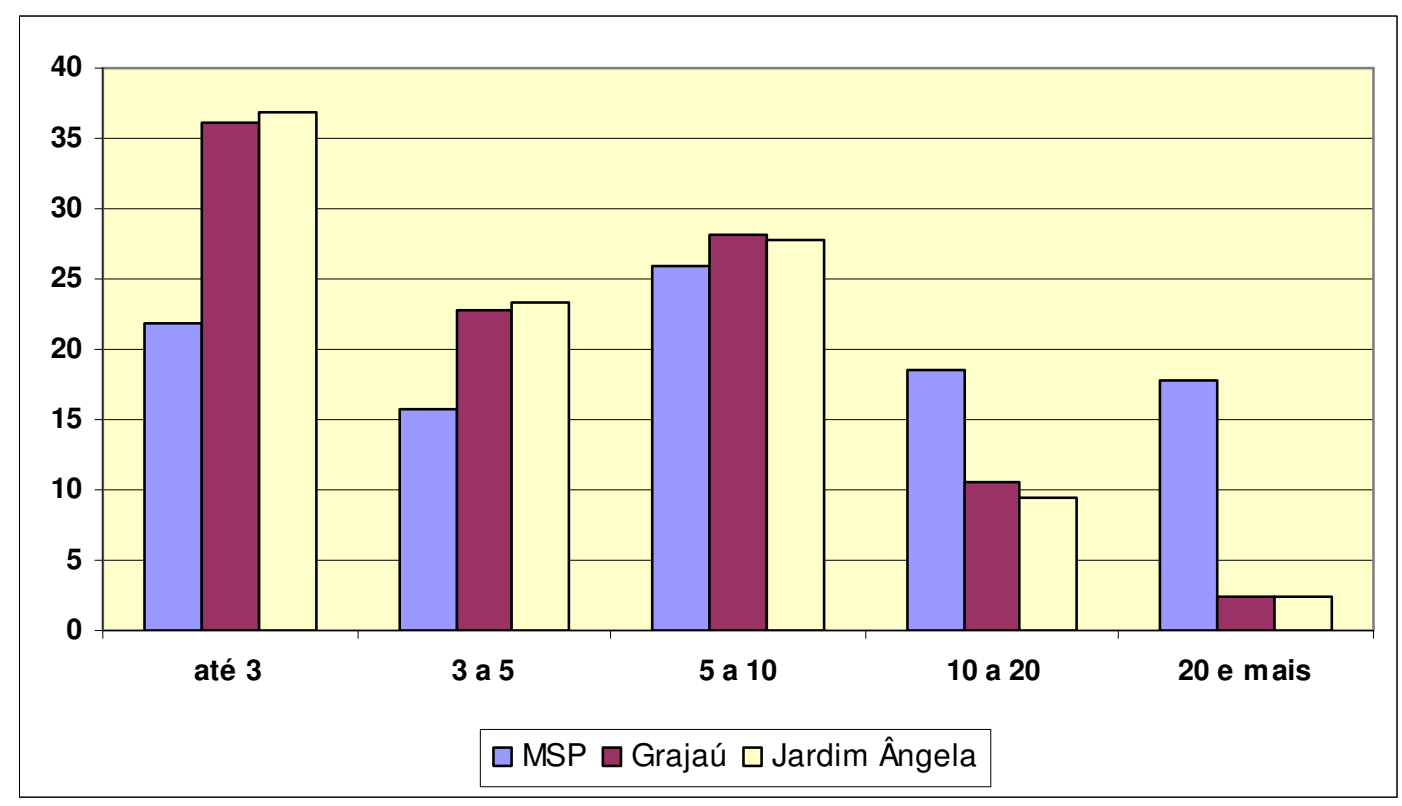

Fonte: Sempla/IBGE

(1) Salário mínimo de referência $\mathrm{R} \$ 151,00$

- Vulnerabilidade social

Estudo desenvolvido pela Secretaria Municipal de Assistência Social e pelo Centro de Estudos da Metrópole - Cebrap (2004) classificou os setores censitários do município de São Paulo, segundo a vulnerabilidade social. Esta foi dimensionada a partir dos setores censitários do Censo Demográfico 2000, considerando duas dimensões: a socioeconômica e a demográfica. A partir de análise fatorial foram relacionadas variáveis representativas para a composição do modelo. Essas variáveis resumidamente indicaram: condição de educação dos responsáveis pelos domicílios; renda; idade; estrutura familiar; e condições de habitação. Para a representação e análise foram criados oito grupos (categorias) ordenados, desde setores sem nenhuma 
privação até aqueles com altíssima privação, associando-os ao grupo populacional mais presente. (CEM, 2004)

A Figura 9 apresenta um recorte para os distritos de Jardim Ângela e Grajaú e permite avaliar, do ponto de vista espacial, os agrupamentos de condição de vulnerabilidade.

Figura 9 - Grupos de vulnerabilidade social por setor censitário, segundo os distritos de Jardim Ângela e Grajaú - 2000.

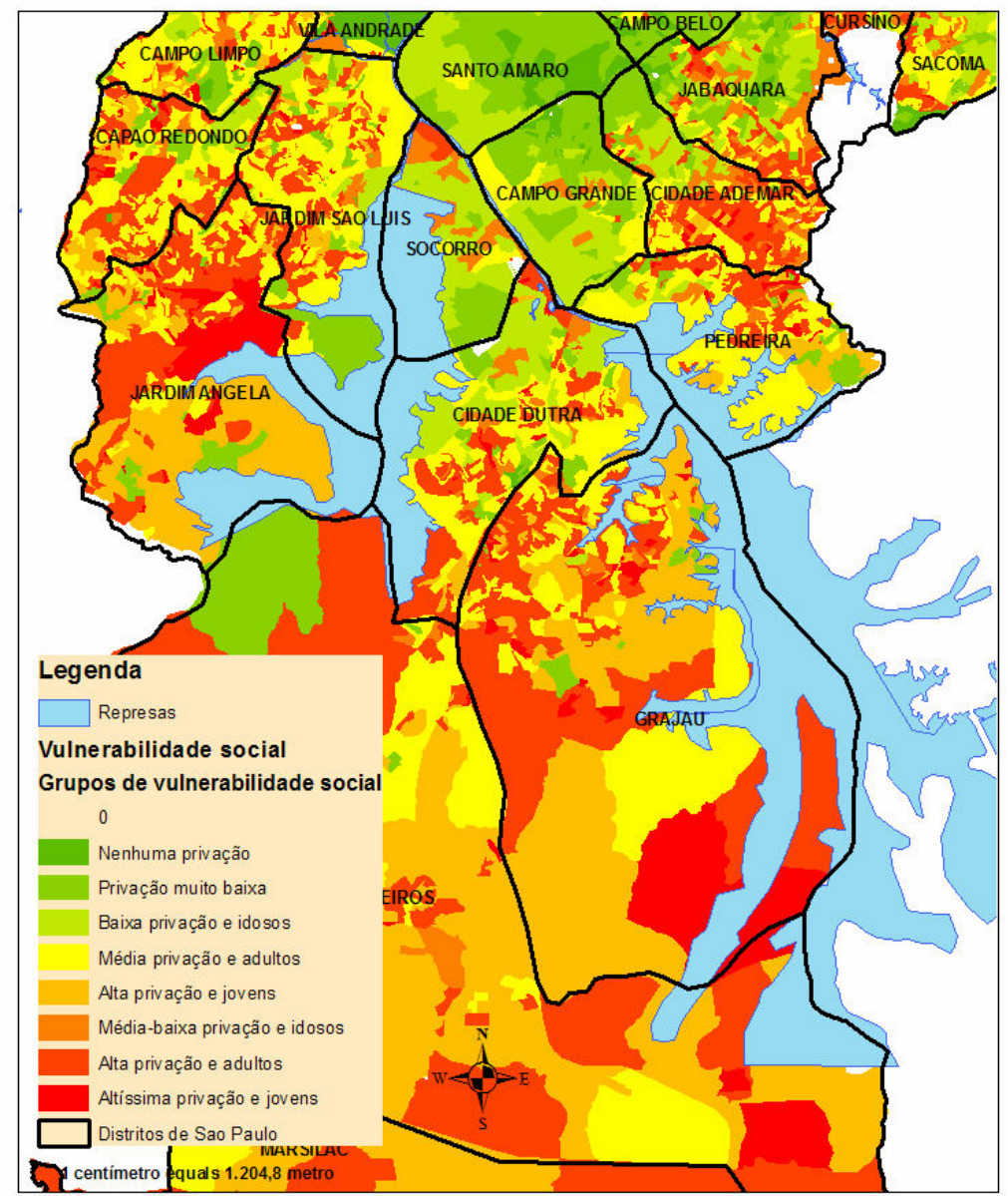

Fonte: Centro de Estudos da Metrópole e IBGE

Comparando o percentual de população classificada segundo os critérios de agrupamento da condição de vulnerabilidade, conforme a Tabela $\mathbf{8}$, verificamos que os grupos de alta e altíssima privação e a presença de jovens reunidos correspondem nos distritos de Grajaú e Jardim Ângela a 35,57\% e 37,59 \%, respectivamente, e 
$11,15 \%$ para o total do município, associando a esse grupo etário uma alta condição de vulnerabilidade social nas áreas de estudo.

Tabela 8 - Percentual da população por grupo de vulnerabilidade, segundo distritos e município de São Paulo - 2000.

\begin{tabular}{lrrr}
\hline \multicolumn{1}{c}{ Grupo de } & \multicolumn{3}{c}{ Unidade territorial } \\
\cline { 2 - 5 } vulnerabilidade & \multicolumn{1}{c}{ Sao Paulo } & Grajaú & Jardim Ângela \\
\hline Não classificada & 0,56 & - & - \\
1. Nenhuma privação & 6,33 & - & - \\
2. Muito baixa privação & 15,72 & 5,93 & 6,21 \\
3. Baixa privação e adultos & 16,34 & 1,19 & - \\
4. Média privação e adultos & 20,71 & 17,48 & 19,82 \\
5. Alta privação e jovens & 7,37 & 30,44 & 28,62 \\
6. Média-baixa privação e idosos & 11,34 & 2,45 & 0,64 \\
7. Alta privação e adultos & 17,85 & 37,38 & 35,74 \\
8. Altíssima privação e jovens & 3,78 & 5,13 & 8,97 \\
\hline Total & $\mathbf{1 0 0 , 0 0}$ & $\mathbf{1 0 0 , 0 0}$ & $\mathbf{1 0 0 , 0 0}$ \\
\hline
\end{tabular}

\section{AS CONDIÇÕES DE HABITAÇÃO, OS ASSENTAMENTOS PRECÁRIOS E AS INIQÜIDADES NO ACESSO AO SANEAMENTO BÁSICO}

A Figura 10 indica a localização das favelas nos distritos de Grajaú e Jardim Ângela, destacadas na cor vermelha. Os números levantados pela Secretária Municipal da Habitação e Centro de Estudos da Metrópole, em estudo conjunto, relativo à localização, identificação e contagem desses agrupamentos habitacionais precários no município, identificaram 2.018 áreas no total, sendo nos distritos do Grajaú e Jardim Ângela encontraram-se, respectivamente, 128 e 153 dessas áreas, o que corresponde a $6,3 \%$ e $7,6 \%$ do total desses agrupamentos habitacionais no município. Comparado com o percentual da população residente de $3,6 \%$ e 2,5\%, respectivamente, para os distritos de Grajaú e Jardim Ângela, pode-se avaliar a grandeza do problema de ocupação e da pressão sobre as áreas de mananciais representadas pelas Represas Guarapiranga e Billings em função desses assentamentos precários. 
Figura 10 - Localização de favelas em distritos da região Sul do município São Paulo - 2000.

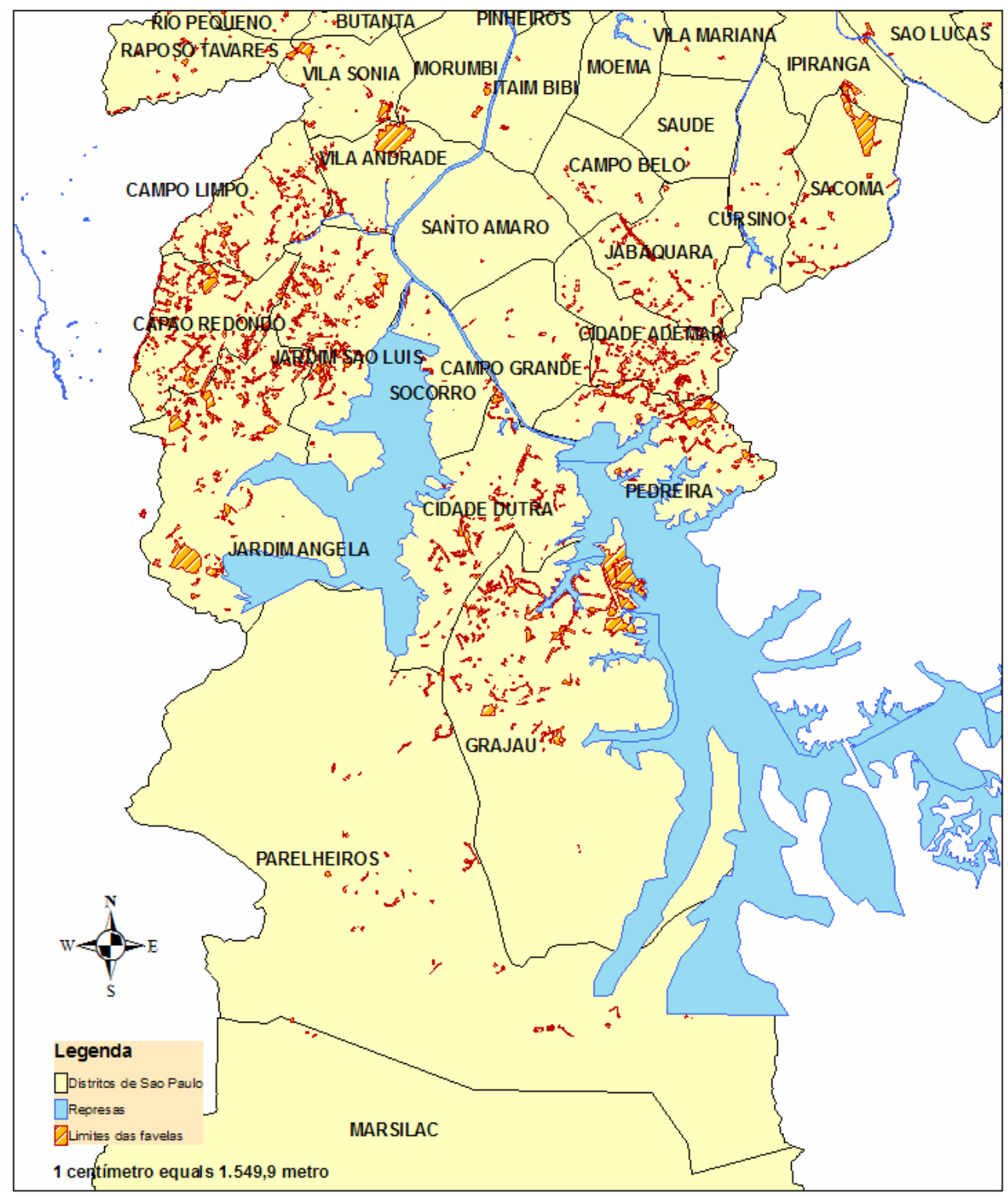

Fonte: Centro de Estudos da Metrópole.

Estudo realizado pela Secretaria Nacional de Habitação do Ministério das Cidades e Centro de Estudos da Metrópole - CEM-Cebrap (2007) com base no Censo Demográfico 2000, sob a temática de Assentamentos precários e capacidades administrativas no Brasil urbano, mostra, por um lado, indicadores relativos a não cobertura da rede geral de água, esgoto e coleta de lixo, ausência de banheiros ou sanitários e percentual de moradias do tipo cômodos e, por outro lado, 
variáveis relativas à condição dos responsáveis por domicílios, como percentual de responsáveis com menos de 30 anos de idade; não alfabetizados; condição de escolaridade e renda. O conjunto de variáveis indica, para os dois distritos do Grajaú e Jardim Ângela, comparativamente ao município de São Paulo, conforme Tabela 9, a precariedade desses assentamentos.

Enfatiza-se, principalmente, no quadro das precariedades, relativamente ao município de São Paulo, a ausência de rede de coleta de esgoto ou inexistência de fossas sépticas, para os distritos de estudo, assim como a baixa escolaridade dos responsáveis pelas famílias e a presença de domicílios cujos responsáveis percebem menos de três salários mínimos mensais, refletindo essa condição na renda média dos responsáveis, que no ano de 2000 correspondia a $35 \%$ e $33 \%$ da média do município, respectivamente, para o Grajaú e Jardim Ângela.

Tabela 9 - Percentual de domicílios e de responsáveis por domicílios pelo conjunto de variáveis características da condição de precariedade dos assentamentos, segundo distritos de estudo e município de São Paulo, 2000.

\begin{tabular}{|c|c|c|c|}
\hline \multirow{2}{*}{ Variáveis } & \multicolumn{2}{|c|}{ Distritos } & \multirow{2}{*}{$\begin{array}{c}\text { Município de } \\
\text { Sao Paulo }\end{array}$} \\
\hline & Grajaú & Jardim Ângela & \\
\hline$\%$ de Moradias do tipo cômodos no total de domicílios & 1,03 & 5,58 & 1,31 \\
\hline$\%$ de domicílios sem rede de abastecimento de água & 2,10 & 4,25 & 1,02 \\
\hline$\%$ de domicílios sem rede de esgoto ou fossa séptica & 33,61 & 24,88 & 8,40 \\
\hline$\%$ de domicílios sem banheiros ou sanitários & 0,31 & 0,45 & 0,23 \\
\hline$\%$ de domicílios sem lixo coletado na porta & 0,93 & 1,17 & 0,65 \\
\hline Média de moradores por domicílio & 3,84 & 3,78 & 3,45 \\
\hline Número de banheiros por domicílio & 1,19 & 1,17 & 1,50 \\
\hline$\%$ de Responsáveis com menos de 30 anos & 21,48 & 23,60 & 14,41 \\
\hline \% de Responsáveis não alfabetizados & 10,36 & 10,94 & 5,62 \\
\hline \% de Responsáveis com menos de 30 anos não alfabetizados & 0,96 & 1,02 & 0,42 \\
\hline$\%$ de Responsáveis com menos de 8 anos de estudo & 68,78 & 71,14 & 47,52 \\
\hline Anos médios de estudo do responsável & 5,37 & 5,23 & 7,81 \\
\hline \% de Responsáveis com renda de até 3 salários mínimos & 59,34 & 61,95 & 39,07 \\
\hline Renda média do responsável & 485,23 & 460,52 & $1.381,40$ \\
\hline
\end{tabular}

Fonte: Ministério das Cidades/CEM, IBGE 


\section{EDUCAÇÃO}

A eqüidade no acesso à educação é essencial para a formação de indivíduos cidadãos, capazes de fazer escolhas informadas, preparados para a obtenção de um espaço no mercado de trabalho, por meio do desenvolvimento de suas funcionalidades para se relacionar com os outros, formar identidades sociais e se integrar socialmente. Podemos afirmar, entretanto, que o acesso à educação é precário nos distritos administrativos de Grajaú e Jardim Ângela onde e a evasão escolar é muito grande, especialmente nas regiões periféricas das grandes cidades como São Paulo. Os distritos de Grajaú e Jardim Ângela são regiões da cidade onde as iniqüidades de acesso à educação se manifestam mais visivelmente.

Atendem a população em idade escolar, conforme Tabela 10, no distrito de Grajaú, 76 unidades de creche e ensino pré-escolar, 54 unidades de ensino de $1^{\mathrm{a}}$. a $4^{\mathrm{a}}$. série, 45 unidades de $5^{\mathrm{a}}$. a $8^{\mathrm{a}}$. série e 30 unidade de ensino médio, tendo, no total, 86.645 alunos matriculados em 2006, número menor que o total da população de 5 a 19 anos no Distrito, que é de 120.068 crianças e jovens. No distrito do Jardim Ângela há, respectivamente, 82 unidades de creche e pré-escola, 44 unidades de ensino de $1^{\mathrm{a}}$. a $4^{\mathrm{a}}$. séries, 36 unidade de $5^{\mathrm{a}}$. a $8^{\mathrm{a}}$ séries e 23 unidades de ensino médio, correspondendo a 66.485 matriculas em 2006, número também menor que a população de 5 a 19 anos, que reside no local, que é de 79.273 crianças e jovens.

Da mesma forma que no município de São Paulo, a totalidade das crianças com idade adequada ao ensino fundamental se matricula na escola, mas os percentuais de matrículas nos níveis seguintes, $2 .^{\circ}$ ciclo e ensino médio, sugerem uma evasão escolar gradativa de um ciclo para outro, o que explica a não universalização do ensino na região. 
Tabela 10 - Índice de matrículas por nível de ensino, segundo município e distritos de estudo, 2006.

\begin{tabular}{lrrrr}
\hline \multirow{2}{*}{ Nível de ensino } & \multicolumn{3}{c}{ Unidade Territorial } \\
\cline { 2 - 5 } & Município & Grajaú & Jardim Ângela \\
\hline Ensino fundamental 1o. Ciclo & 100 & 100 & 100 \\
Ensino fundamental 2o. Ciclo & 91,0 & 86,1 & 90,5 \\
Ensino médio & 57,8 & 40,2 & 45,9 \\
\hline
\end{tabular}

Fonte: PMSP/Sempla

A Tabela seguinte, que explicita melhor as matrículas escolares nos dois distritos, oferece dados de comparação com o município de São Paulo e permite visualizar melhor esse processo de exclusão da escola.

Tabela 11 - Número de estabelecimentos e matrículas por nível de ensino, segundo distritos de estudo e município de São Paulo, 2006.

\begin{tabular}{|c|c|c|c|c|c|}
\hline \multirow{3}{*}{ Unidade territorial } & \multirow{3}{*}{$\begin{array}{c}\text { Estabelecimentos } \\
\text { Matrículas }\end{array}$} & \multicolumn{4}{|c|}{ Nível de ensino } \\
\hline & & \multirow{2}{*}{$\begin{array}{l}\text { Creche e } \\
\text { pré-escola }\end{array}$} & \multicolumn{2}{|c|}{ Ensino fundamental } & \multirow{2}{*}{$\begin{array}{l}\text { Ensino } \\
\text { médio }\end{array}$} \\
\hline & & & 1 a 4 séries & 5 a 8 séries & \\
\hline \multirow{2}{*}{ Município } & Estabelecimentos & 4.766 & 2.416 & 1.942 & 1.203 \\
\hline & Matrículas & 198.540 & 844.730 & 768.705 & 488.210 \\
\hline \multirow{2}{*}{ Grajaú } & Estabelecimentos & 76 & 54 & 45 & 30 \\
\hline & Matrículas & 5.316 & 35.940 & 30.931 & 14.458 \\
\hline \multirow{2}{*}{ Jardim Ângela } & Estabelecimentos & 82 & 44 & 36 & 23 \\
\hline & Matrículas & 3.464 & 26.649 & 24.118 & 12.224 \\
\hline
\end{tabular}

Fonte: PMSP/Sempla

Para tentar explicar a diferença entre a população residente e as que tem acesso à escola e a evasão escolar, o dado de reduções no número de matrículas, quando se analisam os diferentes níveis de ensino, é muito significativo. Considerando o total de matrículas nos primeiros quatro anos de estudo ( $1 .^{\circ}$ ciclo) igual a 100 e comparando os totais do $2 .^{\circ}$ ciclo ( $5^{\mathrm{a}}$. a $8^{\mathrm{a}}$. séries) e ensino médio, temos um índice de 91 e 57,8 para o município e 86,1 e 40,2 para o Grajaú e 90,5 e 45,9 para o Jardim Ângela. Estes dados fazem pensar na qualidade do ensino ministrado na região, que pode estar ampliando a vulnerabilidade da população em idade escolar às violências objeto de estudo desta pesquisa. 


\section{SITUAÇÃO DE SAÚDE}

A situação de saúde dos distritos Grajaú e Jardim Ângela foi avaliada a partir de alguns indicadores, tais como fecundidade, atenção à saúde das gestantes, peso ao nascer e mortalidade infantil, no âmbito da saúde materno-infantil, resultante do potencial genético das crianças e das condições de vida no local. Taxa de mortalidade bruta e por causa para o conjunto da população e as mortes por causas externas, principalmente os homicídios, objeto deste estudo, como os dados vão demonstrar, têm forte presença junto às populações jovens dessas áreas de periferia. A eqüidade no acesso aos serviços de assistência à saúde nas regiões de estudo, um direito da população em geral e dos jovens em particular, não ocorre nesses distritos administrativos conforme será demonstrado.

\section{- Fecundidade}

A Figura 11 indica, para o ano de 2007, a taxa de fecundidade por mil mulheres entre 15 e 49 anos por grupos de idade. Comparativamente com os resultados do município, os distritos do Jardim Ângela e Grajaú apresentam, entre as jovens de 15 e 19 anos, valores superiores à média do município. A gravidez nessa faixa etária implica, muitas vezes, o abandono da escola por parte da mãe adolescente e o aumento do número de pessoas no domicílio de origem da mãe, gerando, por vezes, conflitos entre parentes. 
Figura 11 - Taxa de fecundidade entre mulheres segundo a faixa de idade - 2007.

(Taxa por mil mulheres)

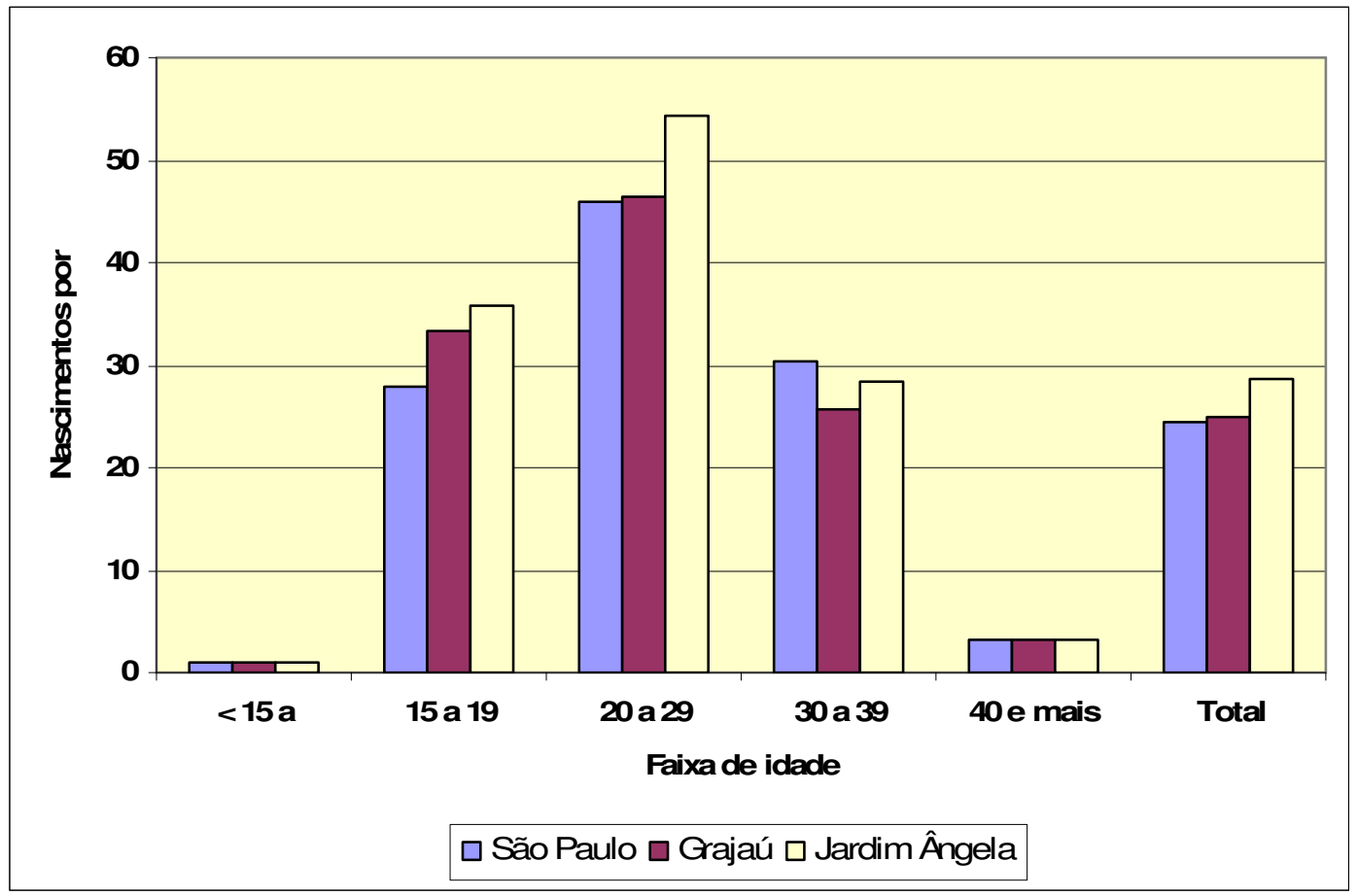

Fonte - PMSP/Sempla

- Atenção à saúde das gestantes

A Tabela 12 aponta o percentual de consultas de assistência pré-natal para os distritos de estudo, relacionando com o município de São Paulo. O distrito do Grajaú apresenta uma freqüência de mulheres com sete ou mais consultas muito inferior àquelas verificadas no Jardim Ângela e no município como um todo, indicando que um percentual menor de gestantes do Grajaú completam o ciclo de consultas do que nas áreas de comparação. 
Tabela 12 - Distribuição percentual de gestantes e o número de consultas médicas de exame pré-natal, segundo distritos de estudo e município de São Paulo (MSP), 2007.

\begin{tabular}{crrr}
\hline \multirow{2}{*}{ Número de consultas } & \multicolumn{3}{c}{ Unidades Territoriais } \\
\cline { 2 - 5 } & \multicolumn{1}{c}{ MSP } & Grajaú & Jardim Ângela \\
\hline Nenhuma & 1,35 & 2,11 & 0,76 \\
1 a 3 & 4,49 & 8,39 & 2,85 \\
4 a 6 & 20,32 & 35,0 & 19,26 \\
7 e + & 72,04 & 52,44 & 76,26 \\
Ignorado & 1,80 & 2,10 & 0,87 \\
\hline Total & 100,00 & 100,00 & 100,00 \\
\hline
\end{tabular}

Fonte: PMSP/Sempla

- Peso ao nascer

Importante indicador da condição de saúde de crianças e gestantes, o peso ao nascer, conforme Tabela 13, para os distritos de estudo e município de São Paulo, obedece, praticamente, ao mesmo padrão. A incidência de baixo peso (menos de 2,499 g) situa-se em torno de 9,5 \% com um pequeno viés para o distrito de Grajaú, que chegou perto dos $10 \%$ nessa categoria. $\mathrm{O}$ índice de fecundidade na faixa etária de 15 a 19 anos, maior que o do município de São Paulo, para os distritos em estudo, pode estar relacionado à distribuição percentual do baixo peso ao nascer, que é tão alto quanto o do município de São Paulo como um todo.

Tabela 13 - Distribuição percentual de peso ao nascer, segundo distritos de estudo e município de São Paulo - 2007.

\begin{tabular}{lrrr}
\hline \multirow{2}{*}{ Peso (em g) } & \multicolumn{3}{c}{ Unidades Territoriais } \\
\cline { 2 - 4 } & MSP & Grajaú & Jardim Ângela \\
\hline$<2.499$ & 9,5 & 9,9 & 9,1 \\
2.500 a 2.999 & 25,6 & 25,5 & 26,4 \\
3.000 a 3.499 & 41,7 & 41,6 & 40,7 \\
3.500 a 3.999 & 19,4 & 19,4 & 20,0 \\
4.000 e + & 3,7 & 3,7 & 3,8 \\
Ignorado & 0,0 & 0,0 & 0,0 \\
\hline Total & 100,0 & 100,0 & 100,0 \\
\hline
\end{tabular}


- Mortalidade infantil

A taxa de mortalidade infantil entre 2000 e 2007 no município de São Paulo apresentou uma redução na taxa por mil nascidos vivos. A Figura 12 demonstra essa tendência, registrando a taxa, no início da década, próxima de 16 óbitos por mil nascidos vivos; para no ano de 2007, aproxima-se dos 12.

Figura 12 - Evolução da taxa de mortalidade infantil (1) entre 2000 e 2007 no município de São Paulo.

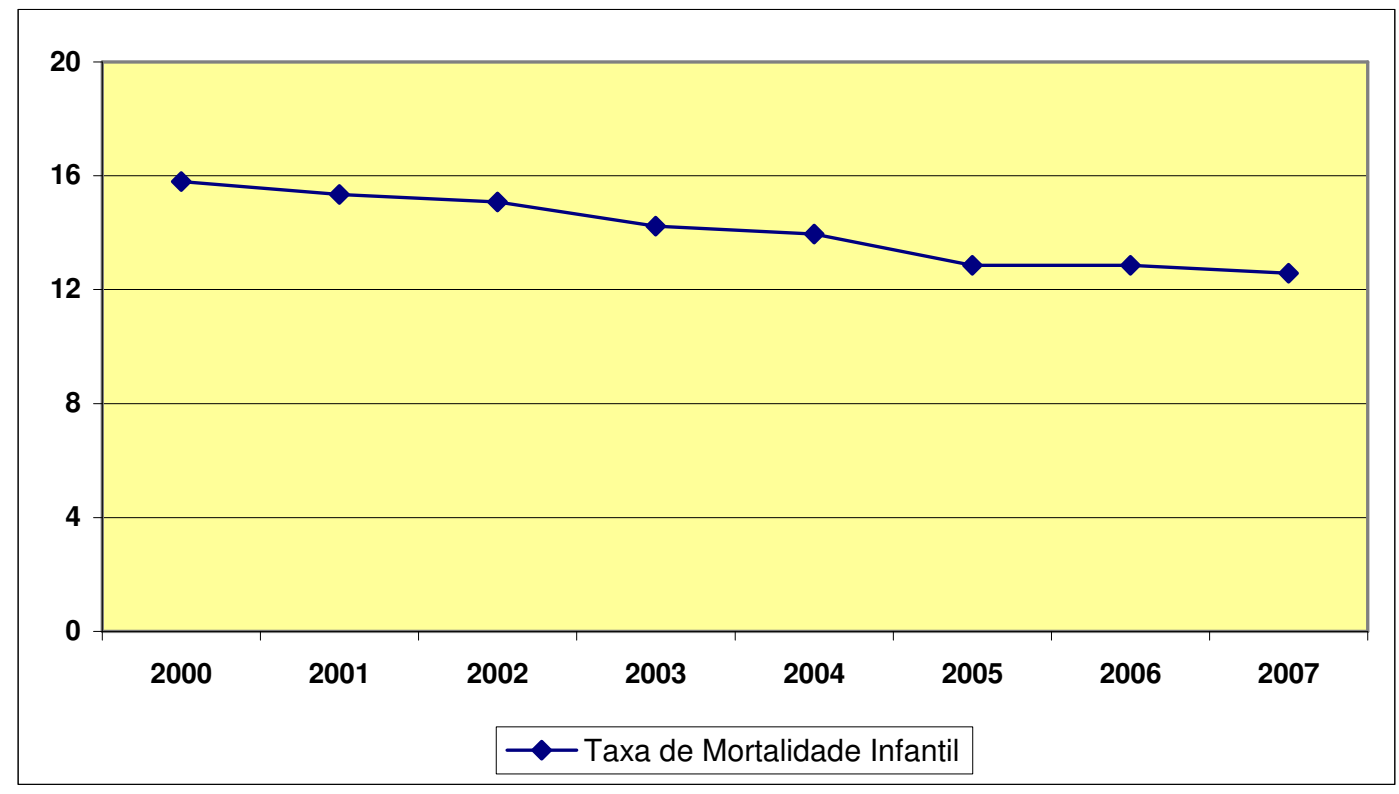

(1) Taxa de mortalidade infantil por mil nascidos vivos

Fonte: PMSP/Sempla

Apesar da redução nos números municipais e do padrão próximo a 12 óbitos por mil nascidos vivos, um valor elevado por si só, nos distritos de estudo esse indicador apresenta um desempenho pior, reflexo das condições de vida e trabalho das famílias que residem nos dois distritos. Analisando os dados de 2007, conforme Tabela 14, verifica-se que as taxas de mortalidade infantil do distrito de Grajaú e Jardim Ângela em relação ao município apresentam valores mais altos. No Grajaú a taxa de mortalidade infantil tanto pós como neonatal, indica valores sensivelmente mais altos, tanto em relação ao município quanto em relação ao distrito de Jardim 
Ângela, o que permite, neste caso, estabelecer conjeturas a respeito do nível de assistência às gestantes, em um e outro distrito, nas redes de proteção social e familiar.

Ressalte-se que as frações relativas à mortalidade neo e pós-neonatal evidenciam, de um lado, uma melhor assistência à saúde, como é o caso da redução dos óbitos neonatais, e por outro lado a melhor condição de vida, com acesso a serviços sanitários básicos e a elevação dos níveis de escolaridade das mães.

Tabela 14 - Número de nascidos vivos, óbitos e taxa de mortalidade infantil, segundo distritos de estudo e município de São Paulo, 2007.

\begin{tabular}{lrrrrr}
\hline Unidades & Nascidos & \multicolumn{2}{c}{ Menores de um ano } & \multicolumn{2}{c}{ Menores de 28 dias } \\
\cline { 3 - 6 } Territoriais & Vivos & Óbitos & Taxa(1) & Óbitos Neonatais & Taxa(1) \\
\hline MSP & 171546 & 2156 & 12,6 & 1407 & 8,2 \\
Grajaú & 6932 & 122 & 17,6 & 86 & 12,4 \\
Jardim Ângela & 5474 & 78 & 14,2 & 58 & 10,6 \\
\hline
\end{tabular}

(1) Taxa de mortalidade infantil por mil nascidos vivos

Fonte : PMSP/Sempla

- Mortalidade geral e proporcional por causa

A taxa de mortalidade bruta, entre 2000 e 2006, no município de São Paulo, apresentou uma pequena redução ao longo do tempo, fixando-se em torno de seis óbitos por mil habitantes em 2005 e 2006. 
Figura 13 - Evolução da taxa de mortalidade geral (1) entre 2000 e 2006 no município de São Paulo

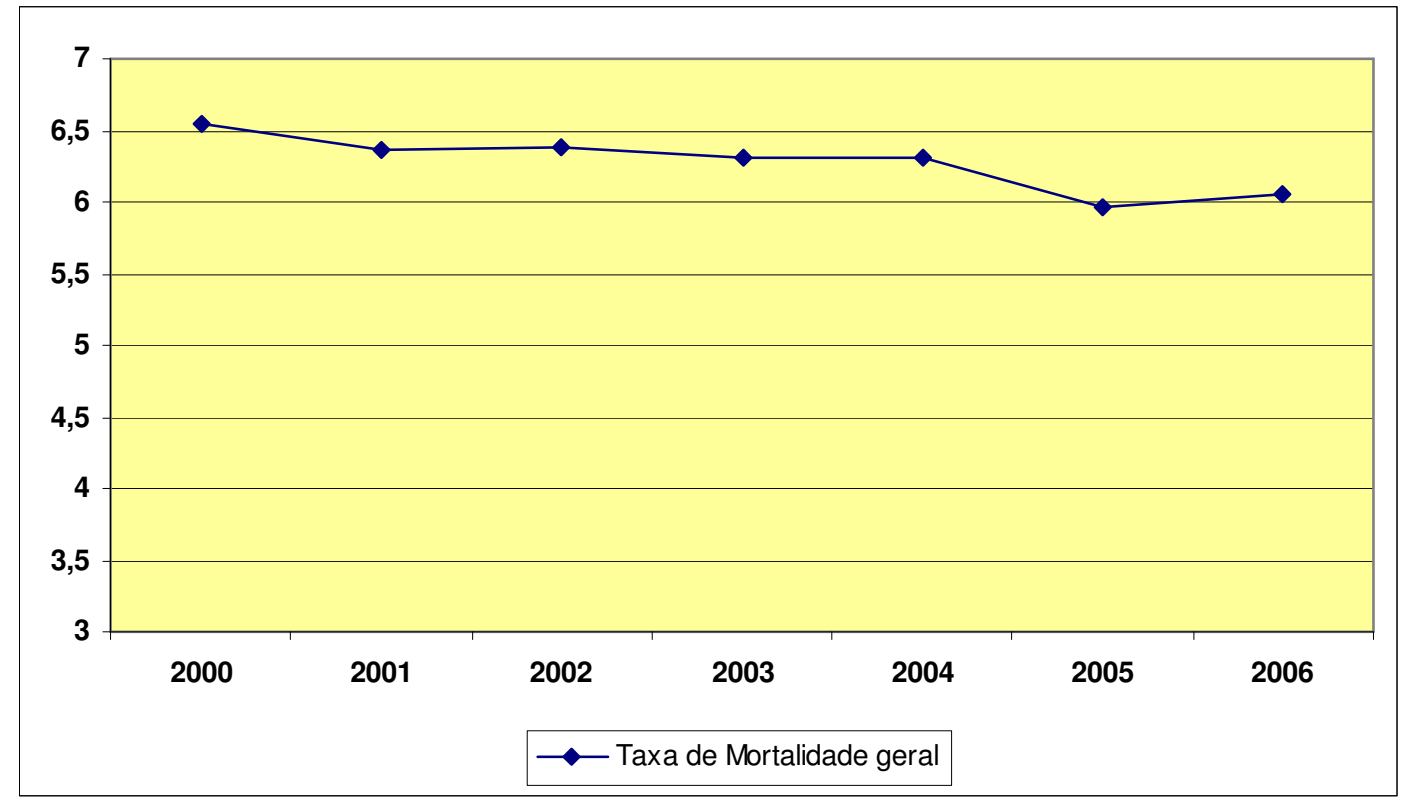

(1) Taxa de mortalidade por mil habitantes

Fonte: PMSP/Sempla

O exame da Tabela 15 indica a mortalidade por causa de morte para o ano de 2007 e permite comparar a proporção de óbitos por tipo de causas entre os distritos de estudo e o município de São Paulo a partir da Classificação Internacional de Doenças - 10 $0^{\mathrm{a}}$; edição - CID 10.

A principal causa de morte tanto no município como nos distritos focados são as doenças do aparelho circulatório, responsáveis por cerca um terço dos óbitos. Enquanto os tumores constituem a segunda causa de morte no município, para os distritos do Grajaú e Jardim Ângela essa posição é ocupada pelas causas externas, em que os homicídios de jovens, como veremos mais à frente, são os responsáveis pela maioria dessas mortes. Merece destaque, ainda, a proporção de óbitos devidos às causas perinatais. Em comparação com o município, esse tipo de causa de mortalidade está perto de três vezes maior no distrito do Grajaú e duas vezes e meia no Jardim Ângela em comparação ao município. 
Tabela 15 - Percentual de óbitos segundo as causas de morte, nos distritos de estudo e município de São Paulo - 2007.

\begin{tabular}{lrrr}
\hline \multirow{2}{*}{ Causas de morte } & \multicolumn{3}{c}{ Unidades Territoriais } \\
\cline { 2 - 4 } & MSP & Grajaú & Jardim Ângela \\
\hline Doenças do Aparelho Circulatório & 32,54 & 31,44 & 29,95 \\
Tumores (Cáncer) & 19,60 & 14,24 & 15,96 \\
Doenças do Aparelho Respiratório & 12,59 & 9,69 & 8,36 \\
Causas Externas & 9,13 & 15,56 & 16,53 \\
Doenças do Aparelho Digestivo & 5,91 & 6,59 & 6,38 \\
Outras causas ou causas mal definidas & 4,69 & 4,22 & 6,85 \\
Doenças Endócrinas, Nutricionais e Metabólič & 4,34 & 3,30 & 3,85 \\
Algumas Doenças Infecciosas & 4,20 & 6,20 & 4,60 \\
Doenças do Sistema Nervoso & 2,96 & 2,18 & 1,60 \\
Doenças do Aparelho Geniturinário & 2,21 & 1,25 & 1,03 \\
Causas Perinatais & 1,82 & 5,34 & 4,88 \\
\hline Total & 100,00 & 100,00 & 100,00 \\
\hline
\end{tabular}

Fonte: Programa de Aprimoramento das Informações de Mortalidade no Município de São Paulo /PRO - AIM.

Analisando comparativamente na Tabela 16 os óbitos para a população de 10 a 49 anos entre as subprefeituras e o município como um todo, verifica-se que a proporção de óbitos decorrentes de agressões e homicídios é muito maior no M'Boi Mirim e Capela do Socorro, o que caracteriza de forma marcante o traço de violência dessas duas regiões, vitimando principalmente a população jovem.

Tabela 16 - Percentual de causas de morte por causas externas (Cap. XX - CID 10) junto a população de 10 a 49 anos, segundo sexo e distritos de estudo e município de São Paulo, 2007.

\begin{tabular}{lrrrrrr}
\hline \multirow{2}{*}{ Causas } & \multicolumn{3}{c}{ Homens } & \multicolumn{3}{c}{ Mulheres } \\
\cline { 2 - 7 } & São Paulo & Grajaú & J. Ângela & São Paulo & Grajaú & J. Ângela \\
\hline Homicídio & 42,7 & 43,0 & 44,6 & 27,5 & 25,0 & 43,8 \\
Lesões de intenção indeterminada & 11,1 & 9,5 & 7,4 & 14,4 & 15,0 & 6,3 \\
Demais acid trânsito e transporte & 9,8 & 9,5 & 17,4 & 15,5 & 20,0 & 12,5 \\
Suicídio & 7,8 & 6,3 & 5,0 & 15,9 & 5,0 & 0,0 \\
Motocic traum em acid transporte & 7,2 & 9,5 & 7,4 & 3,0 & 5,0 & 6,3 \\
Atropelamento de pedestre & 6,9 & 3,8 & 6,6 & 15,7 & 20,0 & 25,0 \\
Queda acidental & 4,9 & 4,4 & 3,3 & 1,9 & 5,0 & 6,3 \\
Intervenção legal & 4,1 & 3,2 & 3,3 & 0,0 & 0,0 & 0,0 \\
Demais causas externas & 5,5 & 10,8 & 5,0 & 6,2 & 5,0 & 0,0 \\
\hline Total & 100,0 & 100,0 & 100,0 & 100,0 & 100,0 & 100,0 \\
\hline
\end{tabular}

Fonte: PMSP/ Pro-AIM 
- A mortalidade por agressões (homicídios)

O número de homicídios, conforme Figura 14, caracterizados pelos eventos descritos pela Classificação Internacional de Doença - CID 10 nos itens de X85 a Y09, apresentou o menor valor em 2006 desde 1996 e tem refletido uma tendência persistente de queda nos últimos anos no município de São Paulo.

Quanto aos distritos do Jardim Ângela e Grajaú, essa tendência se mostra igualmente presente com a inflexão da curva a partir de 2003, para ambas as áreas distritais.

Figura 14 - Evolução do número de homicídios no município de São Paulo e distritos de estudo entre 1996 e 2007.

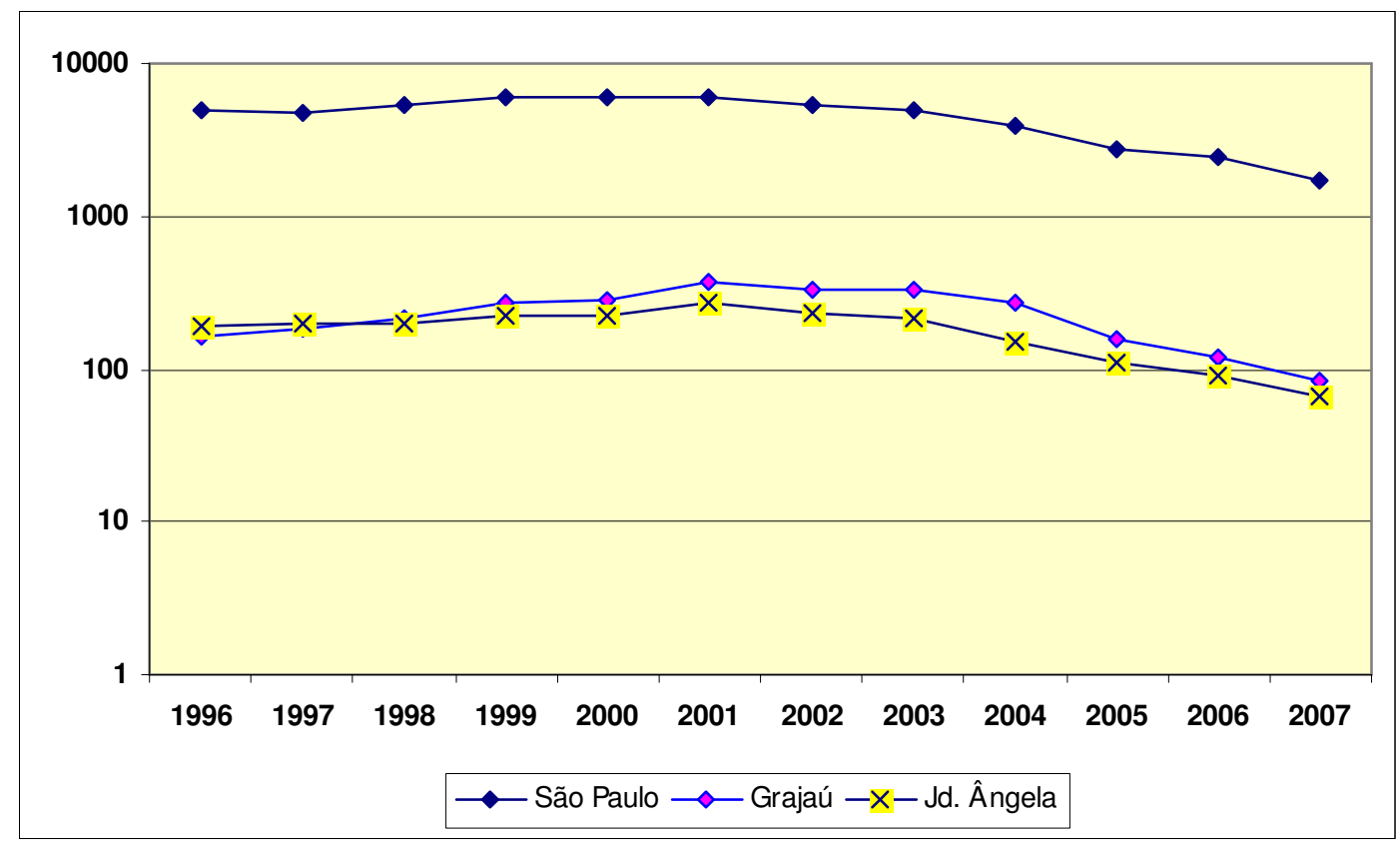

Fonte: PMSP/ Pro-AIM

Os homicídios incidem, principalmente, sobre as populações jovens do sexo masculino. No período entre 1996 e 2007 foram vitimadas, no município de São Paulo, segundo dados da PMSP/PRO-AIM, 54.089 pessoas, sendo 50.007 homens e 4.082 mulheres, o que corresponde a 92,5\% dos óbitos para pessoas do sexo masculino. No distrito do Grajaú, o número de óbitos correspondeu a 2.774 
ocorrências e, no Jardim Ângela, 2.177, sendo 93,8\% e 92,9\% para os homens residentes nos dois distritos, respectivamente.

A proporção de mortes por homicídio nesses distritos supera a proporção de suas populações no município de São Paulo. Considerando a projeção da população residente em 2007, pode-se estimar a participação das populações do Grajaú e Jardim Ângela no município de São Paulo, como 3,9\% e 2,6\% contra 5,1\% e 4,0\% dos homicídios, respectivamente, o que por si só permite classificar essas áreas (Grajaú e Jardim Ângela) como violentas.

Observando a população entre 10 e 19 anos, foco do estudo, verifica-se que o total de homicídios nessa faixa de idade entre 1996 e 2007 registrou o número de 9.416 eventos, o que corresponde a $17,4 \%$ do total de óbitos em todas as idades. No distrito do Grajaú, esta ocorrência atingiu 571 jovens, ou seja, 6,1\% do total do município na faixa de idade considerada e, no Jardim Ângela, 4,9\%. As populações na faixa de idade no distrito do Grajaú e Jardim Ângela correspondem a 4,5\% e 3,0\% da população municipal nesse segmento de idade.

Ao focar o grupo etário de 15 a 19 anos, a proporção de óbitos corresponde a 94,0\%, 92,3\% e 93,8\% do grupo (10 a 19 anos), respectivamente para São Paulo, Grajaú e Jardim Ângela. A Tabela 17 possibilita avaliar, entre 1996 e 2006, o percentual de óbitos de jovens de sexo masculino e com idade entre 15 e 19 anos no grupo etário de 10 a 19 anos.

O estudo Olhar São Paulo - Violência e Criminalidade, do Departamento de Estatística e Produção de Informação - Dipro de 2008, permite, a partir de uma análise espacial, avaliar a densidade de ocorrências de mortes por agressões (homicídios) no município de São Paulo, apontando as áreas de maior incidência desses eventos. A Figura 15, reproduzida do estudo, mostra em dois momentos a intensidade da ocorrência de homicídios entre jovens de 15 a 24 anos. A dinâmica dos eventos, reproduzindo a tendência de redução desses homicídios, fica evidenciada na região de estudo, em que as manchas de densidade têm o tamanho diminuído de 2000 para 2005, assim como a tonalidade das cores representativas. 
Figura 15 - Densidade de ocorrência de homicídios entre jovens de 15 a 24 anos no município de São Paulo - 2000 e 2005.

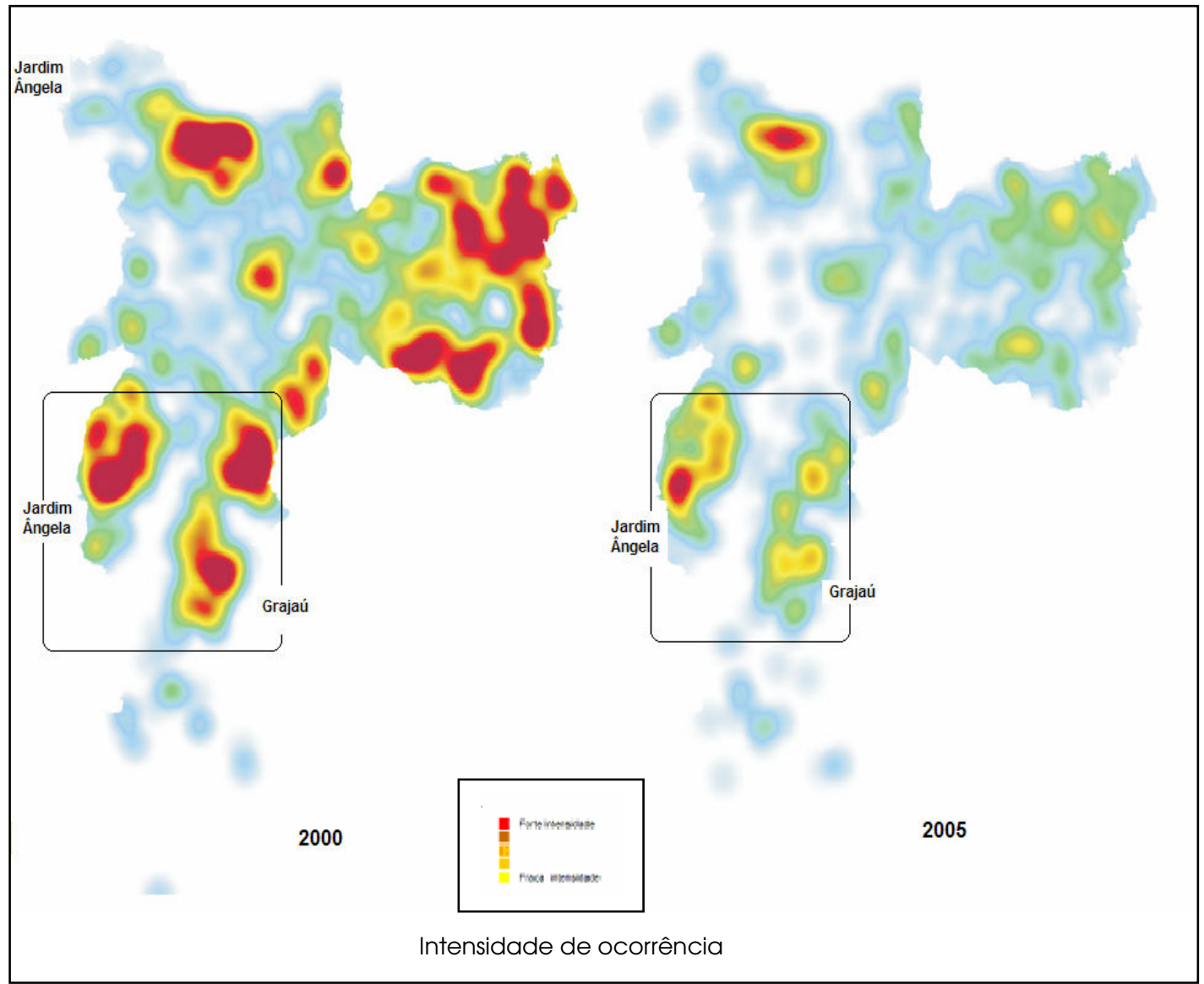

Fonte PMSP/Dipro

- Eqüidade no acesso a serviços de saúde

Atuam no território dos distritos do Grajaú e Jardim Ângela, vinculadas ao atendimento da Prefeitura Municipal, respectivamente, 13 e 21 unidades de atenção à saúde de diversos níveis. A grande maioria são as de atenção primária a Unidades Básicas de Saúde - UBS. 
Tabela 17 - Número e tipo de equipamentos de atenção à saúde nos distritos de estudo e município de São Paulo, 2008.

\begin{tabular}{|c|c|c|c|}
\hline \multirow[b]{2}{*}{ Tipo de equipamento } & \multicolumn{3}{|c|}{ Unidades Territorriais } \\
\hline & Grajaú & Jardim Ângela & São Paulo \\
\hline Unidade Básica de Saúde - UBS (1) & $\overline{10}$ & 18 & 405 \\
\hline Centro de Atenção Psicossocial (2) & & 1 & 32 \\
\hline Ambulatório de Especialidades (3) & 1 & & 23 \\
\hline Centro de Convivência e Cooperativa & & & 20 \\
\hline Hospital & & & 16 \\
\hline Centro de Especialidades Odontológicas - CEO & 1 & & 15 \\
\hline Centro de Atenção Psicossocial Álcool e Drogas & & 1 & 13 \\
\hline Pronto Socorro Geral & 1 & & 12 \\
\hline Serviço de Atendimento Especializado em DST/AIDS & & & 10 \\
\hline Centro de Testagem e Acompanhamento DST/AIDS & & & 9 \\
\hline Assistência Médica Ambulatorial - AMA & & 1 & 6 \\
\hline Pronto Atendimento (4) & & & 4 \\
\hline Outros tipos & & & 25 \\
\hline Total & $\overline{13}$ & 21 & $\overline{590}$ \\
\hline
\end{tabular}

(1) Inclusive com AMA e CEO

(2) Todos os públicos ( Adulto, Infantil e Adolescentes)

(3) Inclusive com Centro de Especialidades Odontológicas e AMA

(4) Inclusive com UBS

A região das subprefeituras de Capela do Socorro e M'Boi Mirim é servida por cinco unidades hospitalares, com 802 leitos, que atendem os distritos de estudo e os demais localizados nessas subprefeituras (Socorro e Cidade Dutra, na sub de Capela do Socorro, e Jardim São Luís, na de M’Boi Mirim). O número de leitos por mil habitantes, que para o município é de 2,9 leitos, na região é de 0,61 e 0,75 leitos por mil habitantes, na subprefeitura da Capela do Socorro e M'Boi Mirim, respectivamente. 
Tabela 18 - População, número de unidades hospitalares, leitos disponíveis e leitos por mil habitantes, segundo subprefeituras de Capela do Socorro, M'Boi Mirim, distritos e município de São Paulo, 2007.

\begin{tabular}{lcccc}
\hline Unidades Territoriais & População & \multicolumn{2}{c}{ Número } & Leitos \\
& 2007 & Hospitais & Leitos & por 1000 habs. \\
\hline São Paulo & 10.834 .244 & 188 & 31392 & 2,90 \\
Capela do Socorro & 656.695 & 3 & 402 & 0,61 \\
Cidade Dutra & 199.119 & 2 & 150 & 0,75 \\
Grajaú & 420.880 & 1 & 252 & 0,60 \\
Socorro & 36.696 & 0 & 0 & 0,00 \\
M'Boi Mirim & 532.313 & 2 & 400 & 0,75 \\
Jardim Ângela & 279.795 & 0 & 0 & 0,00 \\
Jardim São Luís & 252.518 & 2 & 400 & 1,58 \\
\hline
\end{tabular}

Fonte: PMSP/Sempla

- Eqüidade no acesso a equipamentos de cultura, lazer e esportes

Os equipamentos de cultura à disposição das populações da região de estudo podem ser avaliados conforme Tabela 19, que dá conta da pouca disponibilidade de espaços voltados para essas atividades. O conjunto de salas disponíveis para a população, considerando todos os equipamentos e sua vinculação (pública/privada) para ambas as subprefeituras com mais de um milhão de habitantes, resume-se a dez locais

Tabela 19 - Número de equipamentos culturais por tipo, segundo o município e subprefeituras da região de estudo, 2007.

\begin{tabular}{lccc}
\hline \multirow{2}{*}{ Equipamento } & \multicolumn{3}{c}{ Subprefeitura } \\
\cline { 2 - 4 } & São Paulo & $\begin{array}{c}\text { Capela } \\
\text { do Socorro }\end{array}$ & M'Boi Mirim \\
\hline Museus & 81 & - & - \\
Centros Culturais & 64 & 1 & 2 \\
Salas de cinema & 266 & 3 & - \\
Salas nos CEUs & 21 & 3 & 1 \\
Salas de shows & 46 & - & - \\
\hline
\end{tabular}

Fonte: PMSP/Sempla 
Os equipamentos esportivos, segundo a vinculação administrativa, somam para os dois distritos - Grajaú e Jardim Ângela - 42 unidades entre clubes desportivos municipais, campos de futebol e outros tipos de unidades, como pode ser avaliado na Tabela 20.

Tabela 20 - Número de equipamentos por tipo e vinculação administrativa, segundo município e distritos de estudo - 2007

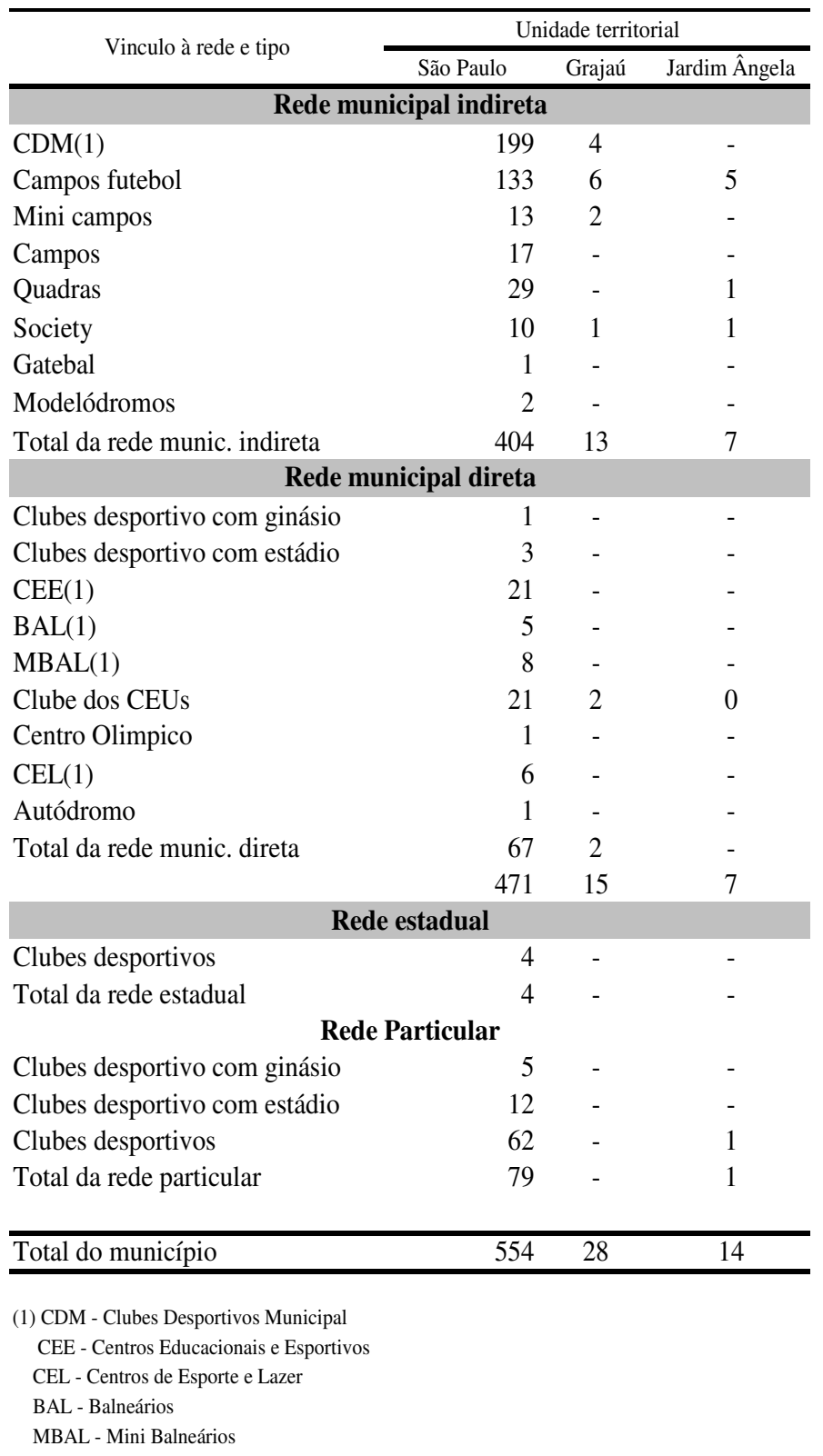

Fonte: PMSP/Sempla 
O lazer vinculado às áreas verdes corresponde, conforme Tabela 21, a índices muito baixos se considerado o município como um todo. A subprefeitura da Capela do Socorro, com uma área de quase $887,0 \mathrm{mil} \mathrm{m} 2$, tem uma taxa de 1,42 m2 por habitante; a subprefeitura de M’Boi Mirim, com uma área de 4,1 milhões de m2, tem uma taxa de 7,58 m2 contra 11,58 m2 para o município de São Paulo como um todo. É importante salientar que tanto a região da Capela do Socorro como a subprefeitura do M'Boi Mirim são banhadas pelas represas Guarapiranga (ambas as subprefeituras) e Billings (somente Capela do Socorro), representando um enorme potencial para o lazer, não só das populações locais, como de todo o município de São Paulo.

Tabela 21 - Existência de áreas verdes em m2 por tipo, segundo o município de São Paulo e subprefeituras da região de estudo - 2008.

\begin{tabular}{lrrrrr}
\hline \multirow{2}{*}{ Unidades Territoriais } & \multicolumn{3}{c}{ Tipo de área verde $(\mathrm{em} \mathrm{m2})$} & \multirow{2}{*}{$\begin{array}{c}\text { Area verde por } \\
\text { habitantes(m2/hab. }\end{array}$} \\
\cline { 2 - 5 } & Parques & Parques Lineares & Praças & Total & \\
São Paulo & 115.798 .573 & 3.043 .462 & 10.618 .945 & 129.460 .981 & 11,58 \\
Capela do Socorro & 117.357 & 90.000 & 679.633 & 886.990 & 1,42 \\
M'boi Mirim & 3.973 .383 & 0 & 154.845 & 4.128 .228 & 7,58 \\
\hline
\end{tabular}

Fonte: PMSP/Sempla

\subsection{O TERRITÓRIO SOB A ÓTICA DOS ATORES}

Neste capítulo serão apresentadas as percepções dos jovens estudantes e não estudantes, dos pais dos jovens não estudantes, lideranças, educadores e profissionais de saúde, sobre o território dos distritos administrativos de estudo.

\subsubsection{As percepções dos jovens e dos seus pais sobre os territórios}

Os dados obtidos nessa fase permitiram verificar que os jovens, assim como os pais, gostam dos bairros onde moram nos respectivos distritos.

Os jovens estudantes entrevistados relataram que gostam de morar no bairro $(73,9 \%)$, sendo $(75, \%)$ no Grajaú e $(71,4 \%)$ no Jardim Ângela, assim como os jovens não estudantes (84,4\%), (Anexos 69 e 70). Não houve diferenças significativas sobre as opiniões dos jovens e entre as faixa etárias. 
A maioria dos pais $(61,5 \%)$ gosta do bairro. No Grajaú verifica-se maior proporção de pais que referem gostar do bairro $(33,3 \%)$ enquanto no Jardim Ângela o percentual foi $17,9 \%$. Também não houve diferenças significativas de opiniões nos distritos - (Anexo 71). Os motivos citados pelos jovens e pais dos jovens não estudantes podem ser verificados no Quadro 9.

Quadro 9- Triangulação dos motivos apresentados pelos jovens estudantes e não estudantes e dos pais destes, para gostarem dos territórios.

\begin{tabular}{|l|l|l|}
\hline Jovens estudantes & Jovens não estudantes & $\begin{array}{l}\text { Pais dos jovens que não } \\
\text { estudam }\end{array}$ \\
\hline Bairro tranqüilo sem violência & Tem amigos & A tranqüilidade do lugar \\
\hline As pessoas são legais & $\begin{array}{l}\text { Nasceram e moram no bairro } \\
\text { há muito tempo }\end{array}$ & Os bons vizinhos \\
\hline $\begin{array}{l}\text { Moram há muito tempo no } \\
\text { bairro }\end{array}$ & Bairro sossegado e tranqüilo & \\
\hline Tem muitos amigos & As pessoas são boas e legais & \\
\hline Lugar bom e simpático & $\begin{array}{l}\text { Todo mundo se conhece e } \\
\text { conhece muita gente }\end{array}$ & \\
\hline
\end{tabular}

Embora a maioria dos jovens estudantes e não estudantes tenham referido que gostam de morar no bairro, houve um pequeno percentual de jovens que relataram não gostar de morar nos distritos. O motivos mais citado entre os jovens que responderam não gostar de morar no Grajaú foi a falta de infra-estrutura e, entre os jovens do Jardim Ângela, foi a falta de respeito dos moradores, violência e insegurança. (Anexo72), conforme quadro 10.

Quadro 10- Triangulação dos motivos apresentados pelos jovens estudantes e não estudantes para não gostarem dos territórios

\begin{tabular}{|l|l|}
\hline Jovens estudantes & Jovens não estudantes \\
\hline Falta de infra-estrutura & Não tem amigos \\
\hline Violência, falta de Segurança & Tudo muito longe \\
\hline Falta de respeito dos moradores & Presença de drogas \\
\hline & Muita violência \\
\hline
\end{tabular}


No Quadro 11, verifica-se que, embora os jovens estudantes, não estudantes e seus pais tenham dito que o bairro é tranqüilo e bom para morar, observam-se contradições, quando estes mencionam os problemas existentes nos distritos.

Quando indagados sobre a existência da violência nos distritos administrativos, mais da metade dos pais respondeu afirmativamente $(53,8 \%)$ (Anexo73). Os tipos de violência existentes nos bairros, segundo os pais dos jovens não estudantes entrevistados, são: tráfico (35,7\%), drogas e álcool (35,7\%), assassinatos $(28,6 \%)$, agressão física $(21,4 \%)$, assaltos e roubos $(17,9 \%)$ e brigas $(14,3 \%)$ ( Anexo 74).

Quanto aos pais terem, na família, jovens que já sofreram violência nos DA, $38,5 \%$ responderam afirmativamente (Anexo75). As violências sofridas pelos jovens citadas pelos pais foram agressões físicas (40\%), assassinatos (20,\%) e assaltos $(20 \%)-($ Anexo 76$)$

Enquanto no Jardim Ângela as violências referidas foram agressões físicas (45,5\%), no Grajaú foram assassinatos (44,4\%), assaltos (33,3\%), agressões físicas $(33,3 \%)$, violência policial $(11,1 \%)$, preconceito $(11,1 \%)$ e violência sexual e estupro $(11,1 \%)$. A diferença entre as variáveis, ao se compararem os distritos, é pouco significativa $(90,20 \%)$.

Os principais problemas que afetam os jovens nas duas regiões de estudo, conforme os pais são: as drogas e o álcool (32,7\%), a falta de emprego (28,8\%), a violência $(23,1 \%)$, espaço para esporte, lazer e cultura $(19,2 \%)$, tráfico de drogas $(11,5 \%)$ e a falta de atividades $(11,5 \%)$ - (Anexo 77 e78). 
Quadro 11 - Triangulação das contradições relacionadas à violência, dos jovens estudantes e não estudantes nos territórios.

\begin{tabular}{|c|c|c|}
\hline \multirow{2}{*}{$\begin{array}{l}\text { Jovens que não } \\
\text { estudam }\end{array}$} & Problemas nos bairros & Problemas nas escolas \\
\hline & Violência & Agressão físicas \\
\hline \multirow{3}{*}{$\begin{array}{l}\text { Bairro sossegado } \\
\text { e tranqüilo }\end{array}$} & $\begin{array}{l}\text { Consumo de drogas e bebidas } \\
\text { alcoólicas }\end{array}$ & Estupros na saída da escola \\
\hline & Prostituição & \multirow[t]{2}{*}{ Agressões dos professores } \\
\hline & Mortes e assassinatos & \\
\hline \multirow{3}{*}{$\begin{array}{l}\text { Jovens } \\
\text { estudantes }\end{array}$} & Falta de segurança & Agressão física \\
\hline & Falta de respeito & \multirow[t]{2}{*}{ Brigas entre colegas } \\
\hline & Violência & \\
\hline
\end{tabular}

De acordo com a análise por triangulação verifica-se que, apesar de os jovens e de os pais dos jovens não estudantes gostarem dos bairros onde moram e considerarem que estes são tranqüilos e bons para morar, os dados indicam a fragilidade das afirmações. Os seus cotidianos estão marcados pela violência, e a aparente tranqüilidade pode ser explicada pelo fato de os jovens terem crescido e convivido com uma história de violência nas regiões, em especial a do Jardim Ângela, e isto pode levá-los a experimentar um certo sentimento de "normalidade" ao conviverem desde cedo com situações de violência nas regiões. Conforme estudo realizado por PERES et al. (2009), parece ser comum os jovens afirmarem a tranqüilidade do bairro onde moram, sendo a imagem que "os de fora" têm do bairro pior do que a realidade. No entanto, segundo a autora "a tranqüilidade presente convive com um passado recente no qual a experiência de violência parece ter sido quase cotidiana" (2009, no prelo) 
- As violências presenciadas e sofridas pelos jovens

A maioria jovens estudantes relata já ter presenciado violência nos bairros dos dois Distritos (76\%) (Anexo79). Entretanto, ao responderem que tipo de violência já presenciaram, referem-se às brigas e violência doméstica. Predominam as brigas entre os pais (padrasto), sendo no Grajaú (27,6\%) e no Jardim Ângela (25,7\%), entre irmãos $(19,8 \%)$ e entre parentes $(10,8 \%)$. Não houve diferenças significativas entre os distritos (Anexo 80). Os jovens não estudantes também dizem ter presenciado violência nos bairros, prevalecendo as agressões físicas nos lares (80\%) (Anexo 81)

$\mathrm{Na}$ questão específica sobre ter presenciado violência em casa, constata-se que a maioria dos jovens já presenciou, sendo $(89,8 \%)$ dos estudantes e $61 \%$ entre os jovens que deixaram de estudar em ambos os distritos. Não há diferenças significativas entre as faixas etárias pesquisadas e nos distritos (Anexos 82 e 83).

A metade dos jovens estudantes relatou que levam surras dos pais $(51,1 \%)$ e houve menções a ferimentos. No Grajaú e no Jardim Ângela, referiram que levam surra e apanham dos pais, $(44,1 \%)$ e $(69,2 \%)$ respectivamente. Os dados indicam que nos dois distritos os jovens convivem com a violência doméstica. Houve ainda relatos de tentativas de suicídio na faixa etária de 15 a 19 anos, no Jardim Ângela (Anexo 84 ).

$\mathrm{O}$ fato de os jovens apanharem dos pais indica que estes acreditam que as crianças e jovens para serem educados precisam ser punidos. Essa é uma das crenças que fundamenta a presença da violência no interior dos lares (SOUZA, 2007).

Os jovens não estudantes também referiram ter sofrido violência em casa, por parte de parentes (38,5\%), surra de pai e mãe $(15,4 \%)$, agressão do marido e namorado $(15,4 \%)$, além de brigas $(30,8 \%)$. Os dados indicam que as jovens que deixaram de estudar e moram com companheiros ou maridos continuam sendo vítimas da violência doméstica - (Anexo 85 ).

No que concerne à violência na escola nos distritos, a maioria dos jovens não estudantes $(64,9 \%)$ comentou ter presenciado, enquanto entre os jovens estudantes o percentual foi de 45,4\% (Anexo 86).

Quanto ao tipo de violência sofrida pelos jovens estudantes, eles relataram: briga entre colegas (34,0\%), agressão física (32,0\%), sendo este tipo de agressão mais citada na faixa etária de 10 a 14 anos; xingamento (18,0\%), preconceito, 
discriminação (4,0\%). Não há diferenças significativas entre os resultados verificados nos distritos.(Anexo 87)

Quanto aos tipos de violência que os jovens não estudantes presenciaram, a maioria referiu brigas entre alunos $(88,0 \%)$. Mencionaram ainda consumo de drogas e tráfico, presença de armas e depredações (Anexo88).

Um percentual de 20,8\% dos jovens não estudantes relataram ter sofrido algum tipo de violência na escola, predominando as agressões (43,8\%), brigas com colegas e xingamentos (12,5\%).Quanto à violência sofrida dentro da escola, citaram ainda a agressão pelos professores $(6,3 \%)$ e, externamente à escola, foi mencionado estupro na saída da escola $(6,3 \%)$.

Concluindo, os jovens estudantes e não estudantes admitiram já ter presenciado violência nas regiões e citam brigas e agressões no domicílio. Metade dos jovens estudantes relatou ter apanhado dos pais, enquanto as jovens não estudantes, além de apanharem dos pais e parentes, quando se casam ou vão morar com os companheiros, continuam sendo vítimas da violência doméstica.

$\mathrm{Na}$ escola a principal violência sofrida pelos estudantes e não estudantes refere-se à agressão física por parte dos colegas; no entanto, os dados indicam que os jovens que deixaram de freqüentar a escola conviveram com um ambiente escolar mais violento do que os jovens estudantes

\subsubsection{Percepções dos educadores sobre a escola}

Os educadores revelam que os principais problemas existentes nas escolas são: espaço físico $(21,4 \%)$, falta de acompanhamento dos pais (20,0\%), falta de funcionários (18,6\%), indisciplina dos alunos (10,0\%), acomodação dos alunos $(8,6 \%)$, falta de professores $(7,1 \%)$, dificuldade financeira $(5,7 \%)$, desestrutura familiar $(5,7 \%)$ e prédio antigo $(5,7 \%)$.

A percentagem de educadores que referem não ter problema de segurança nas escolas é de 50,0\%, e a ronda atende as necessidades, 48,6\%. No entanto verificam-se relatos de ocorrência de violência no entorno das escolas por parte dos alunos e professores. Estes enumeram: invasão, roubos e furtos, circulação de estranhos fora da escola, invasão da quadra, dificuldades com a violência policial, destruição do patrimônio pelos alunos, sentimento de insegurança, drogas na porta 
das escolas, violência noturna, dificuldades de parceria com a comunidade e mato no entorno da escola.

Os educadores referem que existe violência dentro das escolas $(58,6 \%)$ (Anexo Tabela). Citam: agressão verbal (25,7\%), brigas entre os alunos $(24,3 \%)$, violência natural, normal $(12,9 \%)$ e vandalismo, depredações $(5,7 \%)$. Portanto a percepção dos educadores não difere da percepção dos estudantes e não estudantes.

No que concerne ao que mais agrada os educadores na escola, estes mencionam: os alunos (31,4\%), os colegas de trabalho $(18,6 \%)$, a atuação dos professores $(14,3 \%)$, o ambiente de cooperação (14,3\%), as instalações das escolas $(10,0 \%)$ e os objetivos alcançados $(10,0 \%)$ - (Anexo Tabela 84 ). Entre o que mais desagrada os educadores na escola, citam: falta de funcionários (22,9\%), professores $(11,4 \%)$, ausência dos pais $(10, \%)$, excesso de alunos $(8,6 \%)$ e condição dos prédios (8,6\%)- (Anexo Tabela 85).

Constata-se que para os educadores os problemas que mais os incomodam e os desagradam não estão relacionados à qualidade do ensino, currículo e metodologia, e sim aos problemas estruturais, de pessoal, indisciplina dos alunos e falta de participação das famílias.

14.4.3. O território segundo as lideranças, educadores e profissionais de saúde comparado com as opiniões do jovens e dos pais dos jovens fora da escola.

No Quadro 12 podem ser observados, conforme as opiniões das lideranças, educadores e profissionais de saúde, os problemas que mais os incomodam nos distritos e que direta ou indiretamente afetam a vida dos jovens (Anexos: $88,89,90,91,92,93)$. 
Quadro 12 - O que mais incomoda nos bairros por ordem de citação

\begin{tabular}{|c|c|c|c|c|c|}
\hline $\begin{array}{l}\text { Jovens } \\
\text { Estudantes }\end{array}$ & $\begin{array}{l}\text { Jovens não } \\
\text { estudantes }\end{array}$ & Pais & Lideranças & Educadores & $\begin{array}{l}\text { Profissiona } \\
\text { is de Saúde }\end{array}$ \\
\hline $\begin{array}{l}\text { Violência, falta } \\
\text { de segurança }\end{array}$ & $\begin{array}{l}\text { Violência, } \\
\text { prostituição }\end{array}$ & Rua sem asfalto & Violência & $\begin{array}{l}\text { Falta de infra- } \\
\text { estrutura }\end{array}$ & Violência \\
\hline $\begin{array}{l}\text { Falta de } \\
\text { respeito }\end{array}$ & $\begin{array}{l}\text { Ruas sem } \\
\text { asfalto }\end{array}$ & Violência & Álcool e as drogas & $\begin{array}{l}\text { Falta de áreas de } \\
\text { lazer /cultura }\end{array}$ & $\begin{array}{l}\text { Ausência } \\
\text { de lazer e } \\
\text { cultura }\end{array}$ \\
\hline $\begin{array}{l}\text { Falta de asfalto } \\
\text { na rua }\end{array}$ & $\begin{array}{l}\text { Pessoas e o } \\
\text { vizinhos }\end{array}$ & Transporte & Saúde pública & Transporte & $\begin{array}{l}\text { Urbanizaçã } \\
\text { o precária }\end{array}$ \\
\hline $\begin{array}{l}\text { Consumo de } \\
\text { droga, tráfico }\end{array}$ & $\begin{array}{l}\text { Falta de áreas } \\
\text { de lazer }\end{array}$ & Tráfico & Falta de lazer & Violência & $\begin{array}{l}\text { Falta de } \\
\text { cuidado } \\
\text { com o meio } \\
\text { ambiente }\end{array}$ \\
\hline Nada presta & $\begin{array}{l}\text { Não tem área } \\
\text { de lazer }\end{array}$ & $\begin{array}{l}\text { Acesso fácil às } \\
\text { drogas }\end{array}$ & $\begin{array}{l}\text { Falta de } \\
\text { oportunidade de } \\
\text { trabalho }\end{array}$ & Droga /tráfico & $\begin{array}{l}\text { Falta de } \\
\text { ocupação } \\
\text { dos jovens } \\
\text { e adultos }\end{array}$ \\
\hline Sujo/feio & $\begin{array}{l}\text { Mortes, } \\
\text { assassinatos }\end{array}$ & $\begin{array}{l}\text { Falta de } \\
\text { saneamento } \\
\text { básico }\end{array}$ & $\begin{array}{l}\text { Condição sócio- } \\
\text { econômica }\end{array}$ & $\begin{array}{l}\text { Ausência do } \\
\text { poder público }\end{array}$ & $\begin{array}{l}\text { Exclusão } \\
\text { social, } \\
\text { pobreza }\end{array}$ \\
\hline $\begin{array}{l}\text { Faltam parques, } \\
\text { praças }\end{array}$ & $\begin{array}{l}\text { Falta de } \\
\text { transporte }\end{array}$ & $\begin{array}{l}\text { Falta de áreas } \\
\text { de lazer, esporte }\end{array}$ & $\begin{array}{l}\text { Transporte } \\
\text { coletivo }\end{array}$ & $\begin{array}{l}\text { Falta de } \\
\text { emprego }\end{array}$ & Lixo \\
\hline \multirow[t]{2}{*}{ É longe } & $\begin{array}{l}\text { Esgoto ao céu } \\
\text { aberto }\end{array}$ & $\begin{array}{l}\text { Ausência de } \\
\text { serviços, } \\
\text { comércio }\end{array}$ & $\begin{array}{l}\text { Equipamentos } \\
\text { públicos }\end{array}$ & & Transporte \\
\hline & $\begin{array}{l}\text { Comércio } \\
\text { longe e caro }\end{array}$ & Barulho & Moradia precária & & \\
\hline
\end{tabular}

Os dados indicam que os principais problemas existentes nas regiões, na opinião dos pais entrevistados, referem-se à falta de infra-estrutura, destacando ruas sem pavimentação, saneamento básico, transporte, ausência de serviços e comércio, falta de áreas de lazer e esportes, e iluminação.

No Grajaú a qualidade ou falta de saúde pública, falta de transporte e moradia precária foram mais referidas. No Jardim Ângela, falta de lazer e condições socioeconômicas, falta de atividades para os jovens, saneamento básico, falta de ação 
governamental, educação, desemprego e estruturas das escolas, condições das ruas e o excesso de bares os foram mais citados.

No entanto, também é ressaltado que existem coisas boas nos distritos, segundo pais e lideranças. Os pais dos jovens não estudantes apontam o posto de saúde (25\%), verificando-se um maior percentual de citações no Grajaú (33,3\%), a proximidade do comércio $(15,4 \%)$, transporte, escola e a igreja freqüentada $(7,7 \%)$ ( Anexo 94 e95)

Os principais serviços existentes são: a coleta de lixo (38,5\%), posto de saúde $(2,7 \%)$, água $(32, \%)$, energia elétrica $(32, \%)$ e correio $(28,8 \%)$. A diferença entre as variáveis é pouco significativa quando se comparam os distritos $(87,35 \%)$. (Anexo 96).

As lideranças também destacaram os aspectos positivos nos distritos administrativos, que são: a união da comunidade $(26,4 \%)$, o meio ambiente natural $(17,0 \%)$, a solidariedade da população $(13,2 \%)$, as entidades $(13,2 \%)$, as potencialidades dos jovens $(9,4 \%)$ e as redes sociais $(9,4 \%)$, (Anexo 97).

As lideranças entrevistadas consideram que existe violência nas regiões (86,8\%),- (Anexo 98).

No Quadro 13, construído a partir das tabelas anexadas, verificam-se as principais violências existentes nas duas regiões conforme a opinião dos entrevistados - (Anexos 99,100 e 101).Os dados indicam que estão relacionadas ao consumo de álcool e drogas e ao tráfico. Um importante problema constatado nas regiões é a violência doméstica, violência contra a criança e a violência sexual e estupros. É citado o crime organizado, indicando, diante do quadro apresentado, que ele está relacionado com o tráfico de drogas. Os assassinatos também podem relacionar-se com o consumo e tráfico de drogas nas regiões. Para os jovens a principal violência é a doméstica, conforme já apresentado. 
Quadro 13- Violências existentes nos distritos por ordem de freqüência

\begin{tabular}{|l|l|l|}
\hline Lideranças & Educadores & Profissionais de Saúde \\
\hline Drogas e álcool & Drogas e álcool & Drogas e álcool \\
\hline Roubos, assaltos e furtos & Roubos e assaltos & Assassinatos \\
\hline Assassinatos & Assassinatos & Violência doméstica \\
\hline Violência doméstica & Violência doméstica & Tráfico \\
\hline Tráfico & Brigas & Violência contra crianças \\
\hline Violência sexual & $\begin{array}{l}\text { Agressões e violência } \\
\text { física }\end{array}$ & Comportamento agressivo \\
\hline Violência institucional & Tráfico & Assaltos e roubos \\
\hline Agressões & Violência sexual e & Crime organizado e \\
gangues
\end{tabular}

- As opiniões sobre as oportunidades de trabalho para os jovens dos distritos

A falta de oportunidades de trabalho é um dos principais problemas encontrados nos distritos pelos entrevistados.

As lideranças entrevistadas referiram que há trabalho nas regiões $(54,7 \%)$, sendo $60,6 \%$ no DA Grajaú e 45,0\% no Jardim Ângela. No entanto, verifica-se de acordo com as opiniões dos entrevistados que os jovens exercem atividades que não exigem qualificação e outras ligadas ao tráfico de drogas.

As atividades citadas pelas lideranças foram: nos pequenos comércios $(35,8 \%)$ e no trabalho informal $(17, \%)$. No Grajaú são mais citados os trabalhos de entregador/motoboy $(9,1 \%)$, lava-rápido $(6,1 \%)$ e cobradores de lotação $(6,1 \%)$. No Jardim Ângela o trabalho doméstico/babá (10\%) e tráfico (10\%) - (Anexo 102).

A maioria dos educadores entrevistados relataram que não há trabalho nas regiões (68,6\%), assim como os profissionais de saúde (60,6\%) - (Anexo 103 e 104). 
Os trabalhos existentes nas regiões, na opinião de ambos os entrevistados, são: os pequenos comércios, trabalhos informais e programas/projetos das entidades

No Quadro 14 são apresentadas as propostas mais citadas entre os entrevistados para ajudar a resolver os problemas existentes no bairro. Estas referemse à necessidade de políticas públicas destinadas a educação, segurança, trabalho, promoção e fortalecimento das famílias, infra-estrutura e criação de espaços de cultura e lazer.

Quadro 14- Propostas para as regiões por ordem de citação.

\begin{tabular}{|c|c|c|c|}
\hline $\begin{array}{l}\text { Pais dos jovens } \\
\text { não estudantes }\end{array}$ & Lideranças & Educadores & $\begin{array}{l}\text { Profissionais de } \\
\text { Saúde }\end{array}$ \\
\hline $\begin{array}{l}\text { Áreas de lazer, } \\
\text { esporte }\end{array}$ & $\begin{array}{l}\text { Promoção da } \\
\text { educação. }\end{array}$ & $\begin{array}{l}\text { Áreas de lazer, } \\
\text { esporte e cultura. }\end{array}$ & $\begin{array}{l}\text { Atividades de } \\
\text { esportes, lazer e } \\
\text { cultura. }\end{array}$ \\
\hline $\begin{array}{l}\text { Ofertando } \\
\text { empregos }\end{array}$ & $\begin{array}{l}\text { Políticas públicas } \\
\text { adequadas. }\end{array}$ & $\begin{array}{l}\text { Criação de } \\
\text { empregos. }\end{array}$ & Emprego. \\
\hline $\begin{array}{l}\text { Ocupar o tempo } \\
\text { dos jovens }\end{array}$ & $\begin{array}{l}\text { Ação local do } \\
\text { governo. }\end{array}$ & $\begin{array}{l}\text { Presença do poder } \\
\text { público. }\end{array}$ & $\begin{array}{l}\text { Políticas públicas } \\
\text { adequadas. }\end{array}$ \\
\hline $\begin{array}{l}\text { Oferecendo } \\
\text { cursos }\end{array}$ & $\begin{array}{l}\text { Participação da } \\
\text { comunidade. }\end{array}$ & $\begin{array}{l}\text { Mais projetos } \\
\text { sociais. }\end{array}$ & $\begin{array}{l}\text { Melhor infra- } \\
\text { estrutura urbana. }\end{array}$ \\
\hline $\begin{array}{l}\text { Orientação das } \\
\text { famílias }\end{array}$ & $\begin{array}{l}\text { Espaços de cultura } \\
\text { e lazer. }\end{array}$ & $\begin{array}{l}\text { Aumentar o } \\
\text { policiamento. }\end{array}$ & $\begin{array}{l}\text { Retirar os jovens } \\
\text { da ociosidade. }\end{array}$ \\
\hline Melhor educação & $\begin{array}{l}\text { Oferta de } \\
\text { empregos. }\end{array}$ & $\begin{array}{l}\text { Promoção das } \\
\text { famílias. }\end{array}$ & \\
\hline $\begin{array}{l}\text { Colocando a } \\
\text { polícia na rua }\end{array}$ & $\begin{array}{l}\text { Cursos } \\
\text { profissionalizantes. }\end{array}$ & $\begin{array}{l}\text { Melhorar a infra - } \\
\text { estrutura. }\end{array}$ & \\
\hline $\begin{array}{l}\text { Orientação } \\
\text { contra o crime }\end{array}$ & $\begin{array}{l}\text { Investimento em } \\
\text { saúde. }\end{array}$ & $\begin{array}{l}\text { Organização da } \\
\text { comunidade. }\end{array}$ & \\
\hline $\begin{array}{l}\text { Prendendo } \\
\text { traficantes }\end{array}$ & $\begin{array}{l}\text { Melhorar a infra- } \\
\text { estrutura das } \\
\text { regiões }\end{array}$ & $\begin{array}{l}\text { Cursos } \\
\text { profissionalizantes }\end{array}$ & \\
\hline
\end{tabular}


A análise dos dados dessa fase do estudo permite verificar que os jovens gostam das regiões em que moram; no entanto, estes como os seus pais não participam de ações para enfrentamento dos problemas existentes nas regiões. Porém o sentimento de pertencimento, ou seja, o sentimento de "ser"e /ou "estar" num determinado lugar no qual se reconhece como pessoa é um fator positivo e pode vir a mobilizá-los para a participação da gestão social, visando ao desenvolvimento do território e enfrentamento da violência nas regiões.

Embora se observem contradições nos depoimentos dos jovens, estes, os pais, lideranças, educadores e profissionais de saúde consideram como principais problemas nas regiões, além da falta de infra-estrutura, a violência, que muitas vezes decorre do consumo de drogas e do tráfico, e a violência doméstica.

Levando em conta a complexidade dos problemas existentes nas regiões e, ao se considerar o espaço local como um marco estratégico na construção de novas práticas e de compromissos públicos, destaca-se como elemento-chave para o enfrentamento dos problemas, a gestão como uma forma de organização social e de relação entre o político, o econômico e o social. A gestão social "exige não só do poder local, mas de diferentes atores, o desempenho do papel de promotores e articuladores de políticas públicas, desde a sua definição, até a implementação e monitoramento das ações (WESTPHAL; PAIS, 2006, p. 15).

Nessa perspectiva, a intersetorialidade, a integralidade e a participação social configuram-se como elementos que incidem fortemente sobre as possibilidades de inclusão social e de desenvolvimento local. Por intersetorialidade entende-se:

\footnotetext{
Um processo articulado e integrado de formulação e implementação de políticas públicas. Pressupõe a integração de estruturas, recursos e processos organizacionais e se caracteriza pela co-responsabilidade dos diferentes setores governamentais, não governamentais e da sociedade civil, no sentido do desenvolvimento humano e da qualidade de vida. Isso significa a maturidade do setor público em realizar, com participação dos setores governamentais, do empresariado, de organizações não governamentais e da sociedade civil, o diagnóstico de problemas, a identificação de potencialidades e a definição de prioridades (Fernandez; Mendes, 2007 p. 56).
} 
Diante da magnitude e da complexidade dos problemas existentes nas regiões, uma vez que as necessidades sociais apresentam-se de múltiplas formas exigindo intervenções setoriais, o desafio para a gestão social consiste em ampliar a capacidade de resposta dos setores e incentivar e criar espaços para a participação dos jovens, pais e comunidade, para a qualidade de vida e enfrentamento da violência.

\section{AS CONSTRUÇÕES SOCIAIS DOS JOVENS SOBRE A VIOLÊNCIA}

Violência é algo ruim, desagradável que deixa marcas físicas e psicológicas, é também uma violação dos direitos. Violência é tudo o que vivenciamos hoje no mundo (jovens entrevistados).

\section{ANÁLISE DOS DISCURSOS DO SUJEITO COLETIVO DOS JOVENS ESTUDANTES E NÃO ESTUDANTES}

O que você entende por violência?

Figura 16- Resultados Quantitativos - Idéias Centrais - O que você entende por violência?

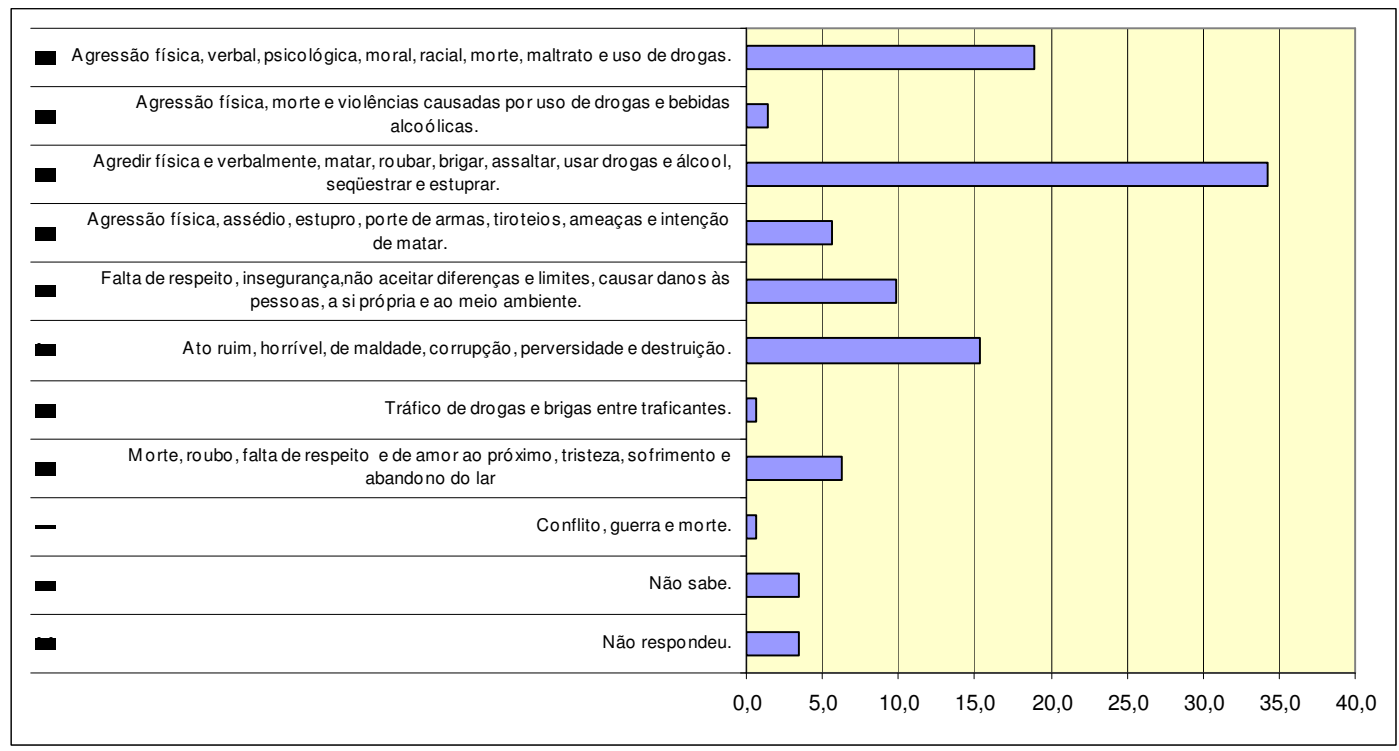

Total de respostas da pergunta: 143 
Os jovens dos Distritos do Grajaú e Jardim Ângela referem que violência é predominantemente: agredir física e verbalmente, matar, roubar, brigar, assaltar, usar drogas e álcool, seqüestrar e estuprar, 49 respostas (34,27\%); seguida da agressão física, verbal, psicológica, moral, racial, morte, maus-tratos e uso de drogas, com 27 respostas $(18,88 \%)$. Em terceiro lugar, a violência é entendida como um ato ruim, horrível de maldade, corrupção, perversidade e destruição, com 22 respostas $(15,38 \%)$.

DSC - Agredir física e verbalmente, matar, roubar, brigar, assaltar, usar drogas e álcool, seqüestrar e estuprar.

Violência é roubar, matar, bater, destruir, usar armas e só, não sei mais. É morte, brigar na rua aqui não tem tanto isso o bairro é bom. É seqüestro, uso de armas e assaltos. Usar drogas, bebidas alcoólicas e traficar drogas.É espancar o outro e discussão que leva o sujeito à morte. É bater sem motivos, essas coisas aí, tudo. Matar é pior.Violência é falta de respeito e falar palavrões e agredir o outro.

Não tenho mente poluída, nunca gostei de violência matar, xingar, roubar, não faço isso.Violência é bater,xingar, arrumar briga com a turma, agredir com palavras, beber e deixar a esposa triste.É se envolver com coisa que não presta, é tudo que não é aceito por Deus e pela sociedade.

Eu vejo cada coisa na televisão! A partir do momento que machuca uma criança até a morte de alguém é violência. É morte, roubo, tráfico, você acaba machucando as pessoas com palavras. Não digo que causa a violência, mas o álcool e drogas, isso me incomoda profundamente. Até mesmo alguns programas que exercem influência negativa sobre as pessoas, dando idéia para a prática do crime. Algo que é feito para incomodar as pessoas por meio de ações que não é legal. Um querer brigar, agredir é o que mais tem aqui no bairro.

Violência é sair por aí matando sem motivo. Ninguém tem direito de tirar a vida do outro.Eu já sofri muito por violência, quase fui estuprada por três vezes. Já fui assaltada, me bateram. Já vi gente morta. Isso tudo é violência. Já vivi muita violência.

Violência é uma coisa que existe muito no Brasil e também muito por parte dos jovens. O que é uma pena!

Só a palavra diz tudo, né? Muitos pais espancam os filhos, maridos batem nas esposas, filhos batem nas mães. É estupro agressão, pedofilia, drogas assassinatos, matar inocentes, sem motivos.

Violência é mal, é ruim, machuca, humilha, dói e agride. Acho que não deveria existir nenhum tipo de violência no mundo..

DSC - Agressão física, verbal, psicológica, moral, racial, morte, maus-tratos e uso de drogas.

Violência é briga, bater um nos outros, murro, tapa, muito sangue. Meu irmão brigando com a mulher, homem batendo em mulher. Não sei mais.

Palavras rudes ditas em horas erradas e palavrão. Pessoas ficarem brigando. É matar roubar, usar drogas, ver os caras fumando crack na minha frente.

São vários tipos de agressão: física, como espancar, mulheres e crianças. Violência verbal, moral, racial. Na boa,isto deveria mudar.

Violência é o ato de agredir e ferir o indivíduo, tanto fisicamente quanto moralmente.É tudo o que possa deforma direta ou indireta machucar os outros. Como por exemplo, este povo que fica me maltratando, fere o meu coração e mesmo que eles não me agridam fisicamente, agridem o meu coração. Acho que é isso. 
Eu entendo que violência é uma coisa muito ruim, as vezes matam as pessoas por coisas bestas, mas não é só matar. É também magoar as pessoas e espancar, é maltratar e manter presas.

Violência é também pessoas que não pensam nas outras, agride e mata sem motivos. É maltratar que nos quer bem.

É matança, obrigar a usar drogas. Violência é muita coisa ruim. É bater e xingar, mas matar é pior, no entanto as palavras as vezes machucam mais do que um tapa. Violência é algo desagradáve que deixa marcas físicas e psicológicas. Violência é tudo o que vivenciamos hoje no mundo.

Os discursos dos jovens demonstram que a violência é um fenômeno de definição complexa, polissêmica e está muito presente no cotidiano dos jovens, quer seja, nas regiões, na sociedade brasileira ou no mundo. Verifica-se que não há diferenças na percepção da violência entre os jovens estudantes e não estudantes, nem entre os jovens das duas regiões de estudo.

Os discursos mostram a vulnerabilidade social que caracteriza a vida dos jovens nos distritos de estudo. Os depoimentos dos jovens refletem a insegurança e a exposição à violência nas suas experiências cotidianas. Eles estão expostos à ocorrência de tiroteios e homicídios, de ter amigos envolvidos em atividades criminosas, de presenciar cotidianamente a venda e consumo de drogas, de sofrer com a violência doméstica e sexual, e ainda é verificada a influência da mídia no cotidiano.

Predomina nos DSCs dos jovens uma visão da violência a partir de sua relação com condições estruturais relativas ao contexto urbano e spcioeconômico em que estão inseridos. No entanto, conforme definição da violência de MINAYO (1999) adotada neste estudo, entende-se que não há um fato denominado violência, e sim violências, "como expressão de exacerbação de conflitos sociais, cujas especificidades necessitam ser conhecidas". Ela tem "profundos enraizamentos nas estruturas sociais, econômicas e políticas, e também nas consciências individuais, numa relação dinâmica entre condições dadas e subjetividade" (MINAYO; SOUZA,1999, p.14).

A violência estrutural, que se impõe sobre a condição de vida das crianças e adolescentes, a partir de decisões histórico-econômicas e sociais, torna vulnerável o seu crescimento e desenvolvimento. O caráter de perenidade e a ausência da intervenção imediata dos indivíduos fazem com que essa forma de violência pareça "naturalizada, como se não houvesse nela a ação de sujeitos" (MINAYO, .2002, p.99). 
Os discursos evidenciam a percepção da banalização da violência, a influência negativa da mídia e as associações entre consumo de álcool e drogas e violência, bem como do tráfico de drogas e violência nas regiões. Os jovens expressam que violência é também falta de respeito ao próximo, ao meio ambiente e à vida, falta de amor e de solidariedade, abandono e corrupção, e ainda mencionam a violência racial e institucional - Anexo (105).

Percebem-se algumas contradições nos discursos no que se refere às experiências dos jovens com a violência: ora a violência parece estar distante, sendo os bairros considerados bons, tranqüilos e seguros, ora a violência parece estar muito próxima, com relatos mostrando que alguns jovens já sofreram muito com a violência. Ninguém tem direito de tirar a vida do outro. Eu já sofri muito por violência, quase fui estuprada por três vezes. Já fui assaltada, me bateram. Já vi gente morta. Isso tudo é violência. Já vivi muita violência.

No entanto fica evidente nos discursos que os jovens conviveram e ainda convivem com a violência e sofrem suas consequiências, nas regiões onde residem, destacando-se a violência doméstica e sexual. 


\title{
16. AS CONSTRUÇÕES SOCIAIS DOS JOVENS SOBRE A PAZ
}

\author{
A pazé fazer do nosso mundo, o melhor, da nossa casa um lugar \\ muito calmo e feliz, pois assim, a partir do momento que mudamos o nosso \\ espaço quadrado, criamos forças pra mudar o quarteirão, depois o bairro e assim vai.
} (Jovem entrevistado)

\section{ANÁLISE DOS DISCURSOS DO SUJEITO COLETIVO DOS JOVENS ESTUDANTES E NÃO ESTUDANTES}

O que você entende por paz?

Figura 17 - Resultados Quantitativos- Idéia Central - $O$ que você entende por paz?

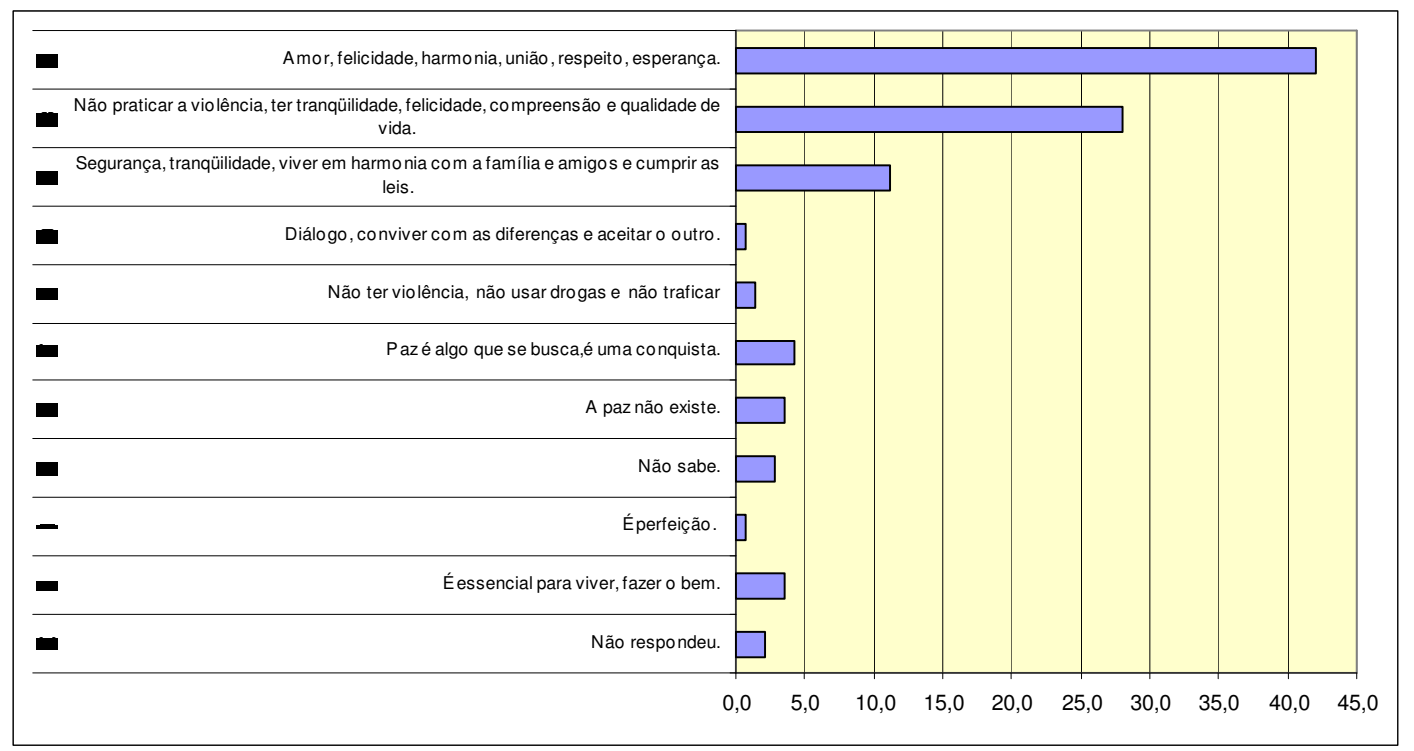

Total de Respostas da Pergunta: 143

Para os jovens dos Distritos do Grajaú e Jardim Ângela, paz é: Amor, felicidade, harmonia, união, respeito, esperança - 60 respostas (41,96\%), seguido de: Não praticar a violência, ter tranqüilidade, felicidade, compreensão e qualidade de vida - 40 respostas $(27.97 \%)$ e Segurança, tranquiilidade, viver em harmonia com a família e amigos e cumprir as leis - 16 respostas $(11,19 \%)$. A paz é entendida ainda como uma conquista, essencial para viver e fazer o bem, diálogo, 
conviver com as diferenças e aceitar o outro, não violência, não usar drogas nem traficar, e também a paz não existe, com cinco respostas $(3,50 \%)$.

Os discursos, sobre a paz, dos jovens estudantes e não estudantes expressam a violência existente no cotidiano. Na tentativa de explicar o que entende sobre a paz, os jovens falam da violência presente nas duas regiões, da violência doméstica, das causas da violência. Destacam ainda a importância da família, da solidariedade, do amor, do respeito, da liberdade, de lutar para conseguir mudanças, visando à melhoria da qualidade de vida e da região, além da expectativa de ter um futuro melhor, como pode ser verificado nos discursos que seguem:

DSC - Amor, felicidade, harmonia, união respeito e esperança.

Paz é ter amor no coração e nunca praticar a violência. É amor, harmonia, alegria, ter carinho e respeitar os outros e ter consideração com os parentes. É viver feliz, sem brigas em paz com os outros, sem morte e sem bebida alcoólica. É poder dormir e acordar sossegado, sem discussão, todo mundo falando normal. Isso é paz.

É não ter violência no bairro. É muita união, nenhum conflito. É ir para minha casa nova, com meu filho e meu companheiro. É ser humilde, compartilhar, fazer as coisas sem jogar na cara dos outros., Fazer do nosso mundo, ou melhor, da nossa casa um lugar muito calmo e feliz, pois assim, a partir do momento que mudamos o nosso espaço quadrado criamos forças pra mudar o quarteirão, depois o bairro e, assim vai.

Todo mundo junto, em união, conversando, sem brigas, filhos respeitando pais e as leis respeito aos mais velhos, família juntas, uma não brigar com a outra. Compartilhar a verdade e dividir as coisas. Tudo que fizer de bom é paz. É estar bem consigo e com a sociedade, andar com liberdade, sem medo do futuro. É um sossego, todos em conjunto em união, todo mundo na igualdade, sem inveja, ninguém querendo ser melhor que o outro. Sem guerra e amizades saudáveis. É viver feliz, paz é uma coisa boa que todo mundo precisa.

É todo mundo junto, lutando por direitos comuns, tentando mudar a região que tem muita violência. É cuidar do ambiente, ter respeito próprio e pelo próximo. É ouvir música e sentir o que ela tem para lhe dizer. É paz de espírito e prática do bem. É ficar sempre de boa, sem problemas. É viver num ambiente agradável, limpo,com harmonia, alegria, com esperança e felicidade. É amar $e$ ser amado, é qualidade de vida. É amor, carinho e paixão pelos seres humanos e com os animais.

Paz é muito bom, é amizade e conviver com as pessoas. Para ter paz é necessário ter respeito, viver sem fronteiras, livre, não machucar o próximo e poder expressar os seus sentimentos. Paz é tudo de bom.É tudo o que leva à felicidade.Paz é todo mundo viver sem briga, fumar um baseado para ficar nas nuvens e viver de boa,sem arrumar briga com o seu namorado, sua família e amigos. É viver e querer ter um futuro melhor sem violência. 
DSC - Não praticar violência, ter tranqüilidade, felicidade, compreensão e qualidade de vida.

Paz é meus irmãos não me baterem mais, viver melhor, sem ter conta para pagar e viver na paz de Jeová. É não ver ninguém brigando, ver o bairro quieto sem violência. É não ter mortes, assaltos, viver em paz, tranqüilo.É não tirar sangue do outro e não ver as pessoas se destruírem.É oposto da violência e mais, estar em equilíbrio comigo mesmo.

É não ter guerras, o mundo sem violência, ninguém se matando. As pessoas vivendo calmas e tranqüilas, com compreensão, sossegado, sem problemas, sem discussão, sem drogas e, sem brigas. $E$ ́́ o que temos aqui agora, sentados, conversando e olhando o mundo em silêncio.

É uma palavra, sei lá. Sem morte, todas as pessoas se respeitam; é procurar Deus e viver curtindo a vida numa boa. É compreensão mútua, ser amigo dos outros, não haver guerra e ter Deus no coração.

É sair na rua olhar pro lado e não ver coisa ruim, não se preocupar. É ficar bem com a vida e exclui tudo o que é violência. É viver sossegado, sem se preocupar com nada. É ser feliz e ter alguém que seja feliz com você e que as pessoas não sejam violentas umas com as outras por qualquer coisa.

É levar a vida como se fosse o último momento. É entrosamento, algo saudável, que não faz os outros sofrerem por violência. É não sofrer agressões e poder sorrir e ser feliz.

A paz é um tranquiilizante para todos os seres vivos dessa terra. É não xingar, não roubar, não bater, não estuprar não ser ignorante, não maltratar, não ser mal educado.É quando não tem ninguém para te machucar.É ficar em casa sem coisa ruim.É ter mais escolas, mais hospitais, postos de saúde. Abaixar o valor dos médicos, as pessoas conseguirem um emprego melhor e as faxineiras ganharem mais.

A análise dos DSCs permite constatar que os jovens deixam transparecer valores, atitudes, comportamentos e estilo de vida, presentes na cultura de paz, conforme (Guimarães, 2005, p.2), entre eles: o respeito à vida, o fim da violência e a promoção da não violência, o respeito pleno e a promoção de todos os direitos humanos e as liberdades fundamentais; o compromisso com a resolução pacífica dos conflitos; as necessidades de desenvolvimento e proteção do meio ambiente, o respeito e a promoção do direito ao desenvolvimento; o respeito e o fomento do direito de todas as pessoas à liberdade de expressão, opinião e informação; a adesão aos princípios de liberdade, justiça, tolerância, solidariedade, cooperação, pluralismo, diversidade, diálogo e entendimento em todos os níveis da sociedade e entre nações.

Os discursos dos jovens sobre a paz estão em consonância com a definição contida na Declaração e Programa de Ação sobre a Cultura de Paz de 1999: a paz requer "um processo positivo, dinâmico e participativo em que promova o diálogo e se solucionem os conflitos com um espírito de entendimento e cooperação mútuos" (MILANI, 2005; GUIMARÃES, 2005). 
Diferentemente do conceito de paz, em que a paz é compreendida como uma condição estática e definitiva, na perspectiva da cultura de paz, "incorporam-se o dinamismo, as múltiplas interações, a polissemia e polifonia e o caráter processual, inacabado e inesgotável do conceito de cultura" (MILANI, 2005, p. 54).

O conceito de cultura de paz possui um elemento sistêmico, indicando que o corpo social, político e econômico da sociedade deve ser reconstruído, tratando-se, portanto, de uma ampla visão de paz que abrange elementos relativos tanto aos macroprocessos da sociedade, como também os microprocessos sociais (GUIMARÃES, 2005).

Nesse sentido os jovens apresentam argumentos como: A paz é ter mais escolas, mais hospitais, postos de saúde. Abaixar o valor dos médicos, as pessoas conseguirem um emprego melhor e as faxineiras ganharem mais". Na esfera microsocial, os jovens mostram a importância de construir relações sociais, é amizade e conviver com as pessoas (....) é compartilhar as coisas com meus amigos, fazer o bem e conquistar as pessoas para fazerem o bem.

Valorizam o papel da família: a minha família, ela me traz sossego e o desejo de um mundo melhor. A esperança de cada dia nos torna mais fortes e aumenta o desejo de que um dia o mundo e as pessoas que vivem nel, mudem para melhor.

A paz deve ser pensada multiculturalmente, como realidade intersubjetiva, como uma agenda para a paz, com positividade e como construção. É uma cultura em permanente construção e mudança e cada pessoa, ao mesmo tempo que faz parte dela, participa de sua configuração. Sendo assim, "a perspectiva de co-construção, participação, cidadania e processo individual e coletivo proporcionado pela cultura de paz é fundamental para mobilizar vontades e compromissos de forma consciente e responsável” (MILANI, 2005, p.54).

É nessa perspectiva que os jovens entendem a paz. A paz é: fazer do nosso mundo o melhor, da nossa casa um lugar muito calmo e feliz, pois assim, a partir do momento que mudamos o nosso espaço quadrado, criamos forças pra mudar o quarteirão, depois o bairro e assim vai. 


\section{AS ACCÕES COLETIVAS NOS DISTRITOS DO GRAJAÚ E JARDIM ÂNGELA.}

Para analisar projetos e ações nos distritos administrativos do Grajaú e Jardim Ângela, foram entrevistados: as lideranças das entidades existentes nos territórios que tinham projetos destinados aos jovens de 10 a 19 anos, sendo 20 entidades no DA do Grajaú e 33 no Jardim Ângela; os diretores e/ou coordenadores pedagógicos das escolas municipais e estaduais, 46 no Grajaú e 24 no Jardim Ângela; os profissionais de saúde das Unidades de Saúde, 12 no Grajaú e 21 no Jardim Ângela; e os gestores das subprefeituras, sendo cinco em cada distrito administrativo.

Participaram da rede de indicações 92 entidades do Grajaú e 70 do Jardim Ângela. A rede foi constituída a partir das respostas à questão formulada aos entrevistados sobre entidades, pessoas ou projetos que estes conheciam na região com projetos/ações destinados aos jovens na faixa etária de 10 a 19 anos para a promoção da saúde e enfrentamento da violência.

\subsection{PROJETOS, PROGRAMAS E AÇÕES DESENVOLVIDOS NOS DISTRITOS DO GRAJAÚ E JARDIM ÂNGELA}

Os projetos, programas e ações identificados nas escolas das regiões dos dois Distritos Administrativos foram categorizados e organizados em oito grandes temas, isto é, os mais recorrentes dentre o material coletado, quais sejam: área educacional, área cultural, área ambiental, área da saúde, área de esporte e lazer, área profissionalizante, desenvolvimento psicossocial e participação, comunicação e cidadania. Essa categorização foi determinada a partir da leitura dos objetivos e da descrição de cada projeto da entidade/instituição e serviço entrevistado, destinado aos jovens na faixa etária de 10 a 19 anos nas duas regiões de estudo.

Para classificar as entidades responsáveis pelos projetos desenvolvidos nas duas regiões de estudo, utilizamos a Tipologia dos Atores da Sociedade Civil, desenvolvida por LAVALLE, CASTELLO e BICHIR (2006), descrita no Capítulo Metodologia. Segundo os autores o estudo das organizações civis impõe o desafio de desenvolver caracterizações capazes de organizar de modo coerente a complexidade e diversidade inerente a esses atores. 
De acordo com os critérios utilizados na tipologia elaborada por LAVALLE, CASTELLO e BICHIR (2006), as entidades que participaram do estudo nas duas regiões foram classificadas como: ONGs, organizações populares, associações de bairro, associações comunitárias, entidades assistenciais, articuladoras e fóruns.

Na Tabela 22, verifica-se a distribuição das entidades conforme a tipologia adotada e observa-se que, no Grajaú, predominam as Associações de Bairro (33,3\%), bem como maior atuação de ONG/OSCIP, e, no Jardim Ângela, as Entidades Assistenciais (61,9\%).

Tabela 22 - Tipo de Associação - DA Grajaú e Jardim Ângela, São Paulo, 2008.

\begin{tabular}{|lrrr|}
\hline \multicolumn{1}{r}{ Tipo de Associação } & \multicolumn{2}{c|}{ Distrito } & \multirow{2}{*}{ TOTAL } \\
\cline { 2 - 4 } & Grajaú & Jardim Ângela & 37 \\
\hline Entidade Assistencial & 21,2 & 61,9 & 25,9 \\
Associação de Bairro & 33,3 & 14,2 & 11 \\
Associação Comunitária & 12 & 9,5 & 5,6 \\
Fórum & 6,1 & 4,8 & 5,6 \\
Entidade Educacional/ Esportiva & 6,1 & 4,8 & 5,6 \\
Subprefeitura & 6,1 & 4,8 & 9,3 \\
ONG/OSCIP & 15,2 & 0 & $\mathbf{1 0 0}$ \\
Total & $\mathbf{1 0 0}$ & $\mathbf{1 0 0}$ & \\
\end{tabular}

Os valores da tabela são os percentuais em coluna estabelecidos sobre 70 observações.

- Projetos e ações desenvolvidos pelas escolas dos distritos

Verifica-se na Tabela 23 que há predominância de projetos da Área de Participação, comunicação e cidadania $(60,0 \%)$. Em seguida, os projetos da Área Educacional (50,0\%), Ambiental (42,9\%, Área da Saúde (37,1\%), Área de Desenvolvimento psicossocial (18,6\%) e Esporte e Lazer (12,9\%). A distribuição dos projetos, conforme os distritos, pode ser verificada na Tabela 6. 
Tabela 23 - Tipos de projetos e ações das escolas- DA do Grajaú e Jardim Ângela São Paulo, 2008.

Projetos, programas e ações (tipo)

\begin{tabular}{rrrr}
\hline \multicolumn{2}{c}{ Distrito } & \multicolumn{2}{c}{ TOTAL } \\
\cline { 1 - 2 } Grajaú & \multicolumn{2}{c}{ Jardim Ângela } & \\
\hline 60,9 & 58,3 & 60,0 \\
58,7 & 29,2 & 48,6 \\
50,0 & 50,0 & 50,0 \\
52,2 & 25,0 & 42,9 \\
39,1 & 33,3 & 37,1 \\
17,4 & 20,8 & 18,6 \\
10,9 & 16,7 & 12,9 \\
2,2 & 0,0 & 1,4 \\
2,2 & 8,3 & 4,3 \\
\hline 100 & 100 & 100 \\
\hline
\end{tabular}

Os valores da tabela são os percentuais em coluna estabelecidos sobre 70 observações.

A Tabela 24 mostra que a maioria dos projetos são destinados aos alunos $(84,3 \%)$ no DA Jardim Ângela. Há também projetos que envolvem a comunidade $(24,3 \%)$, alunos e professores(12,9\%), comunidade escolar $(14,3 \%)$ e a comunidade $(12,9 \%)$.

Tabela 24 - Participantes dos projetos - DA Grajaú e Jardim Ângela - São Paulo, 2008

\begin{tabular}{|c|c|c|c|}
\hline \multirow{2}{*}{ Público-participante } & \multicolumn{2}{|c|}{ Distrito } & \multirow{2}{*}{ TOTAL } \\
\hline & Grajaú & Jardim Ângela & \\
\hline Não resposta & 2,2 & 16,7 & 7,1 \\
\hline Alunos & 89,1 & 75 & 84,3 \\
\hline Alunos e comunidade & 23,9 & 25 & 24,3 \\
\hline Alunos e professores & 8,7 & 20,8 & 12,9 \\
\hline Comunidade escolar & 17,4 & 8,3 & 14,3 \\
\hline Comunidade & 10,9 & 16,7 & 12,9 \\
\hline TOTAL & 100 & 100 & 100 \\
\hline
\end{tabular}

Os valores da tabela são os percentuais em coluna estabelecidos sobre 70 observações.

Os principais objetivos dos projetos que foram agrupados, conforme critério descrito, foram: Conscientizar para o meio ambiente $(37,1 \%)$, integrar comunidade escola $(30,0 \%)$, promover cultura e crenças $(27,1 \%)$, desenvolver a auto-estima $(17,1 \%)$, alfabetizar $(12,9 \%)$, atividades de lazer e cultura $(12,9 \%)$, conservar o 
patrimônio escolar (12,9\%), prevenir aids e DSTs $(11,4 \% 0$, desenvolver habilidades de leitura e escrita (10,0\%), prevenir álcool e drogas $(10,0 \%)$.

No que se refere aos colaboradores das escolas, a maioria dos educadores entrevistados não respondeu, pressupondo-se que não existam colaboradores (48,6\%). O maior colaborador é o governo/prefeitura (21,4\%), sendo mais referido no Jardim Ângela $(33,3 \%)$. Seguido de professores e funcionários das escolas $(11,4 \%)$, comunidades e alunos ( $8,6 \%)$, empresas privadas e voluntários $(7,15 \%)$. No Jardim Ângela, verifica-se maior participação de voluntários (16,3\%), da comunidade e alunos (12,5\%) - ( Anexo 107 )

As dificuldades relatadas pelas entidades entrevistadas foram: dificuldades materiais $(42,9 \%)$, sendo predominante nos dois Distritos. A segunda maior dificuldade refere-se à participação e envolvimento dos alunos, comunidade escolar e comunidade $(28,6 \%)$, sendo maior no Grajaú $(37, \%)$. A dificuldade de organização é citada no Jardim Ângela $(12,5 \%)$ e as dificuldades de falta de profissionais $(4,3 \%)$ nos dois distritos - (Anexo108)

Os educadores relatam que nas escolas há participação dos jovens nos projetos $(71,4 \%)$, sendo que $30 \%$ participam na sala de aula com os professores. $\mathrm{Na}$ Tabela 25 observamos as formas de participação referidas pelos educadores.

Tabela 25-Formas de participação dos jovens nos projetos das escolas - DA Grajaú e Jardim Ângela - São Paulo -2008.

\begin{tabular}{|c|c|c|c|}
\hline \multirow{2}{*}{ Como jovens participam } & \multicolumn{2}{|r|}{ Distrito } & \multirow{2}{*}{ TOTAL } \\
\hline & Grajaú & Jardim Ângela & \\
\hline Na sala de aula com professores & 34,3 & 20,0 & 30,0 \\
\hline Sugestão dos alunos & 22,9 & 33,3 & 26,0 \\
\hline Conselho da escola & 20,0 & 20,0 & 20,0 \\
\hline Projetos dos alunos mediados pelos educadores & 20,0 & 6,7 & 16,0 \\
\hline Consulta questionário/seminário & 14,3 & 13,3 & 14,0 \\
\hline Por intermédio do grêmio & 5,7 & 20,0 & 10,0 \\
\hline Representantes de classe & 2,9 & 6,7 & 4,0 \\
\hline Reunião com pais & 5,7 & 0,0 & 4,0 \\
\hline Dialogo aberto & 0,0 & 6,7 & 2,0 \\
\hline Só a minoria participa & 0,0 & 6,7 & 2,0 \\
\hline Caixa de opiniões & 0,0 & 6,7 & 2,0 \\
\hline TOTAL & 100 & 100 & 100 \\
\hline
\end{tabular}

Os valores da tabela são os percentuais em coluna estabelecidos sobre 50 observações. 
- Os projetos e ações desenvolvidos pelas entidades/lideranças dos Distritos

As maioria das entidades dos distritos administrativos desenvolve projetos e ações destinados aos jovens na faixa etária de 10 a 19 anos, na área de participação comunicação e cidadania $(57,4 \%)$. Verificam-se projetos na área educacional $(44,4 \%)$ sendo um percentual maior no DA do Jardim Ângela (60,6\%). Na área de desenvolvimento psicossocial $(35,2 \%)$, o percentual maior é no Jardim Ângela (47,6\%), assim como projetos profissionalizantes, esportivos, ambientais, na área de saúde e assistencial, conforme apresentado na Tabela 26.

Tabela 26 - Área de atuação dos projetos - DA Grajaú e Jardim Ângela São Paulo, 2008 .

\begin{tabular}{|c|c|c|c|}
\hline \multirow[b]{2}{*}{ Áreas de atuação dos projetos } & \multicolumn{2}{|c|}{ Distrito } & \multirow[b]{2}{*}{ TOTAL } \\
\hline & Grajaú & $\begin{array}{l}\text { Jardim } \\
\text { Ângela }\end{array}$ & \\
\hline Participação, comunicação e cidadania & 54,5 & 61,9 & 57,4 \\
\hline Educacional & 60,6 & 19,0 & 44,4 \\
\hline Desenvolvimento psicossocial & 27,3 & 47,6 & 35,2 \\
\hline Cultural & 27,3 & 28,6 & 27,8 \\
\hline Profissionalizante & 15,2 & 23,8 & 18,5 \\
\hline Esportivo & 18,2 & 19,0 & 18,5 \\
\hline Ambiental & 15,2 & 19,0 & 16,7 \\
\hline Saúde & 12,1 & 19,0 & 14,8 \\
\hline Assistencial & 15,2 & 9,5 & 13,0 \\
\hline TOTAL & 100 & 100 & 100 \\
\hline
\end{tabular}

Nos dois distritos administrativos, os projetos e ações, em sua maioria, são destinados a crianças e adolescentes $(75,9 \%)$; no entanto, há entidades que atendem somente crianças $(45,3 \%)$ e outras só adolescentes $(7,4 \%)$. Há projetos que atendem a comunidade de forma geral (66,7\%). Algumas também desenvolvem projetos e ações para idosos $(9,3 \%)$ e portadores de necessidades especiais $(1,9 \%)$ - (Anexo 109)

Verifica-se que, entre os principais projetos/ações desenvolvidos nas duas regiões de estudo, predomina o projeto dos Núcleos Socioeducativo (27,8\%). Os Núcleos Socioeducativos pertencem à rede de serviços socioassistenciais de proteção 
básica da Prefeitura, que atendem crianças e adolescentes de 6 a 24 anos, em situação de vulnerabilidade social decorrente da pobreza.

Seguem, por ordem de citação: as atividades culturais (22,2\%), atividades esportivas e de lazer $(18,5 \%)$ e creches $(16,7 \%)$. Há também projetos/ações referentes à cursos profissionalizantes (11,1\%), MOVA - Educação de adultos (9,3\%), Viva Leite- distribuição de leite $(7,4 \%)$, meio ambiente $(7,4 \%)$, idosos (7,4\%), ensino religioso (7,4\%), Programa Pró-Jovem (7,4\%). (Anexo 109).

O Pró-Jovem é um programa do governo federal, implantado no município de São Paulo por quatro secretarias: Secretaria do Desenvolvimento e Assistência Social, Secretarias do Trabalho, Educação, Participação e Parceria, por meio da Coordenadoria da Juventude. É direcionado a jovens de 18 a 24 anos de idade que não tenham concluído a $8^{\mathrm{a}}$ série do Ensino Fundamental, devendo ter concluído pelo menos a $4^{\mathrm{a}}$ série. Tem por finalidade proporcionar formação integral ao jovem, por meio de elevação de sua escolaridade (conclusão do Ensino Fundamental). Visa à qualificação profissional, ao desenvolvimento de ações comunitárias e à reinserção social.

Os principais colaboradores das entidades entrevistadas são: a Prefeitura da Cidade de São Paulo (46,3\%), ONGs (29,6\%), sendo estas as mais citadas no Grajaú $(39,4 \%)$, voluntários $(22,2 \%)$, comunidade $(24,1 \%)$, empresas privadas $(16,7 \%)$ e o Governo do Estado de São Paulo (13,\%). Há ainda colaboração do governo federal $(1,9 \%)$, fundação e grupos estrangeiros $(3,7 \%)$ e de políticos (1,9\%). 18\% dos entrevistados não responderam.

As principais dificuldades encontradas pelas entidades/lideranças foram: financeira $(48,1 \%)$ e materiais e equipamentos $(33,3 \%)$. Há ainda entre as mais citadas dificuldades com falta de profissionais e colaboradores $(18,1 \%)$ e espaço físico (13\%), - (Anexo 110)

Os entrevistados referiram que os jovens participam dos projetos e ações desenvolvidos pelas entidades (83,3\%), nos dois distritos. Quanto ao tipo de participação, 42,2\% dos jovens dão sugestões para os projetos. O percentual maior de repostas é verificado no Jardim Ângela (60\%). A forma de participação mais freqüente é aquela por meio de reuniões específicas (20\%).. 
Tabela 27 - Forma de participação dos jovens nos projetos e ações das entidades DA- do Grajaú e Jardim Ângela - São Paulo, 2008.

\begin{tabular}{|c|c|c|c|}
\hline \multirow{3}{*}{ Como os jovens participam } & \multicolumn{2}{|c|}{ Distrito } & \multirow{3}{*}{ TOTAL } \\
\hline & & Jardim & \\
\hline & Grajaú & Ângela & \\
\hline$\overline{\text { Dando sugestões/idéias }}$ & 33,3 & 60,0 & 42,2 \\
\hline Por meio de reuniões específicas & 20,0 & 20,0 & 20,0 \\
\hline Desenvolvem projetos & 16,7 & 6,7 & 13,3 \\
\hline Emitindo opinião & 16,7 & 13,3 & 15,6 \\
\hline Discussão, conversas & 13,3 & 6,7 & 11,1 \\
\hline Avaliações sistemáticas & 3,3 & 13,3 & 6,7 \\
\hline Trabalho voluntário & 10,0 & 6,7 & 8,9 \\
\hline Fazendo demandas & 6,7 & 6,7 & 6,7 \\
\hline Por meio do grêmio & 3,3 & 0,0 & 2,2 \\
\hline Promovem eventos & 3,3 & 0,0 & 2,2 \\
\hline Liderança de classe & 0,0 & 6,7 & 2,2 \\
\hline Não resposta & 6,7 & 0,0 & 4,4 \\
\hline TOTAL & 100 & 100 & 100 \\
\hline
\end{tabular}

Os valores da tabela são os percentuais em coluna estabelecidos sobre 45 observações.

- Projetos, programas e ações desenvolvidos pelas Unidades de Saúde dos Distritos do Grajaú e Jardim Ângela

As Unidades de Saúde entrevistadas desenvolvem projetos e ações predominantemente na área da saúde $(93,6 \%)$. Foram citados também projetos na área cultural $(15,2 \%)$ e educacional $(9,1 \%)$. Projetos e ações da área cultural foram referidos no DA do Grajaú $(23,1 \%)$; na área ambiental, $(6,1 \%)$ nos dois distritos pesquisados; projetos e ações na área de desenvolvimento psicosssocial (10\%), referidos no Jardim Ângela; e esportivo, referido no Grajaú (7,7\%) - (Anexo111).

As ações referentes à área esportiva desenvolvidas pelas Unidades de Saúde referem-se ao Cecco - Centro de Convivência e Cooperativa Interlagos, por meio de parceria com o Centro Desportivo Municipal - Escola de Velas, e também as ações desenvolvidas pelo Programa Práticas Integrativas em Saúde: Práticas Corporais e Meditativas das Medicinas Tradicionais Chinesa, que abrange caminhada, capoeira, Lien Ch'i, Tai chi chuan, Liang- Gong.

Os programas e as ações das unidades de saúde são destinados à promoção, prevenção e assistência à saúde de adultos, crianças e adolescentes, de acordo com as diretrizes dos Programas de Saúde do Ministério da Saúde e das áreas Técnicas da 
Secretaria Municipal da Saúde. A Área Técnica de Saúde da Criança e do Adolescente tem como objetivo planejar a assistência integral à saúde da criança e do adolescente, dentro dos princípios do SUS, visando diminuir a morbimortalidade infantil e de jovens, e promover ações de promoção e prevenção de saúde.

As ações citadas pelos entrevistados referenciaram o atendimento universal em saúde (42,4\%), sendo 33,3\% das ações destinadas aos adolescentes. Conforme citado pelos coordenadores das unidades de saúde entrevistados, $27,3 \%$ são ações destinadas à gestante. - (Anexo 112). Os resultados indicam que os adolescentes procuram as Unidades de Saúde para participar dos Programas destinados a gestantes.

A Tabela 28 mostra os objetivos das ações desenvolvidas pelos profissionais de saúde. Destacam-se as ações de assistência à gravidez e puerpério (33,3\%) , educação sexual $(33,3 \%)$, sendo mais referida no DA do Grajaú $(46,2 \%)$ e ações de orientação para a utilização de métodos contraceptivos.

As Unidades de Saúde desenvolvem o Programa Mãe Paulistana, criado pela Prefeitura de São Paulo. A Rede de Proteção à Mãe Paulistana oferece assistência integral a gestantes, acompanhando os atendimentos realizados, inclusive dos bebês, durante o primeiro ano de vida. 
Tabela 28 -Objetivos dos programas, projetos e ações desenvolvidos pelas Unidades de Saúde - DA do Grajaú e Jardim Ângela - São Paulo, 2008.

\begin{tabular}{|c|c|c|c|}
\hline \multirow{2}{*}{ Objetivos } & \multicolumn{2}{|c|}{ Distrito } & \multirow{2}{*}{ TOTAL } \\
\hline & Grajaú & Jardim Ângela & \\
\hline Gravidez e Puerpério & 30,8 & 35,0 & 33,3 \\
\hline Educação sexual & 46,2 & 25,0 & 33,3 \\
\hline Métodos contraceptivos & 23,1 & 30,0 & 27,3 \\
\hline Promover qualidade de vida & 15,4 & 30,0 & 24,2 \\
\hline Controle de hipertensão e diabetes & 23,1 & 20,0 & 21,2 \\
\hline Redução de risco de doenças & 0,0 & 25,0 & 15,2 \\
\hline Consulta médica de rotina & 7,7 & 15,0 & 12,1 \\
\hline Cidadania, cultura, política & 23,1 & 5,0 & 12,1 \\
\hline Planejamento familiar & 7,7 & 10,0 & 9,1 \\
\hline Arte, dança & 0,0 & 5,0 & 3,0 \\
\hline Saúde bucal & 7,7 & 5,0 & 6,1 \\
\hline Dependência química & 7,7 & 5,0 & 6,1 \\
\hline Relaxamento e condicionamento físico & 0,0 & 10,0 & 6,1 \\
\hline Controle de peso & 7,7 & 5,0 & 6,1 \\
\hline Saúde da mulher & 7,7 & 5,0 & 6,1 \\
\hline Educação ambiental & 7,7 & 5,0 & 6,1 \\
\hline Qualidade de vida pop vulneráveis - mental & 0,0 & 5,0 & 3,0 \\
\hline Informações de saúde & 0,0 & 5,0 & 3,0 \\
\hline Avaliação de risco & 0,0 & 5,0 & 3,0 \\
\hline AIDS, DST & 7,7 & 0,0 & 3,0 \\
\hline Orientação alimentar & 0,0 & 5,0 & 3,0 \\
\hline Atendimento psicológico & 0,0 & 5,0 & 3,0 \\
\hline Promover aproximação de usuários & 0,0 & 5,0 & 3,0 \\
\hline Tratamento da Tuberculose & 7,7 & 0,0 & 3,0 \\
\hline Medicina chinesa & 0,0 & 5,0 & 3,0 \\
\hline Promoção de relacionamento familiar & 7,7 & 0,0 & 3,0 \\
\hline Não resposta & 23,1 & 5,0 & 12,1 \\
\hline TOTAL & 100 & 100 & 100 \\
\hline
\end{tabular}

Os valores da tabela são os percentuais em coluna estabelecidos sobre 33 observações.

Quanto aos colaboradores das Unidades de Saúde, 57,6\%, não responderam, indicando que a metade das Unidades de Saúde não tem colaboradores. Entretanto, os profissionais que responderam citaram como principais colaboradores as entidades e associações $(15,2 \%)$, os voluntários e profissionais $(15,2 \%)$, as escolas $(9,1 \%)$, o Ministério da Saúde $(9,1)$, a Prefeitura, por meio da Secretaria $(6,1 \%)$ e da Coordenadoria de Saúde Sul (3,0\%). Houve menções à Organização Social - Centro de Estudos e Pesquisa João Amorim - Cejam e Fundo Municipal da Saúde (Anexo113). 
As dificuldades encontradas pelos coordenadores das unidades de saúde entrevistados referem-se à falta de adesão ao tratamento pelos usuários (27,3\%), sensibilização da população $(21,2 \%)$ e falta de pessoal $(15,2 \%)$ - (Anexo114).

Os profissionais de saúde referiram que $63,6 \%$ dos jovens participam das ações e projetos desenvolvidos nas Unidades de Saúde, que ocorre nos grupos $(52,4 \%)$, em reuniões e palestras $(28,6 \%)$, durante o atendimento e consultas $(14,3 \%)$ e pelo acolhimento dos agentes comunitários de saúde $(4,8 \%)$. Os dados sugerem que a participação dos jovens está relacionada às ações referentes a gravidez e puerpério, educação sexual e métodos contraceptivos. ( Anexo Tabela 115)

\section{2.REDES SOCIAIS DE PROTEÇÃO AOS JOVENS}

\subsubsection{A identificação de uma rede de proteção}

O levantamento de campo relacionou e entrevistou 162 entidades que atuam nos distritos do Grajaú e Jardim Ângela. Dessas entidades, 69 são escolas de ensino fundamental e médio da rede pública, incluindo as escolas administradas pela Prefeitura do município e pelo Estado. No âmbito da saúde, foram relacionadas 31 entidades entre unidades básicas de saúde - UBS e centros de apoio como CAPS, Creca. As entidades civis, representadas por organizações não-governamentais ONGs, associações comunitárias, de bairro e assistenciais, bem como unidades esportivas e culturais e os fóruns e conselhos, somaram 52 organizações. Figuram como entidades independentes dez setores das subprefeituras da Capela do Socorro e M'Boi Mirim que atuam diretamente com jovens e adolescentes, tais como as supervisões de assistência social, coordenações de esporte e cultura, conforme Tabela 29. 
Tabela 29 - Tipos de entidades existentes no DA Grajaú e Jardim Ângela - São Paulo, 2008.

\begin{tabular}{lrrrrrrr}
\hline \multirow{2}{*}{ Tipo de entidade } & \multicolumn{4}{c}{ Distrito } & \multicolumn{2}{c}{ TOTAL } \\
\cline { 2 - 5 } & \multicolumn{2}{c}{ Grajaú } & \multicolumn{3}{c}{ Jardim Ângela } & & \\
\hline & $\mathbf{N}$ & $\%$ & $\mathbf{N}$ & $\%$ & $\mathbf{N}$ & $\%$ \\
\hline Escolas & 46 & 50,0 & 23 & 32,9 & 69 & 42,6 \\
Saúde & 12 & 13,0 & 19 & 27,1 & 31 & 19,1 \\
Assistencial & 8 & 8,7 & 12 & 17,1 & 20 & 12,3 \\
Cultural/esportiva & 3 & 10,9 & 3 & 5,7 & 6 & 8,6 \\
Associação & & & & & & \\
comunitária & 2 & 5,4 & 2 & 7,1 & 4 & 6,2 \\
Associação de Bairro & 10 & 2,2 & 4 & 2,9 & 14 & 2,5 \\
ONG/OSCIP & 4 & 4,3 & 1 & 1,4 & 5 & 3,1 \\
Subprefeitura & 5 & 3,3 & 5 & 4,3 & 10 & 3,7 \\
Forum/Conselho & 2 & 2,2 & 1 & 1,4 & 3 & 1,9 \\
\hline TOTAL & $\mathbf{9 2}$ & $\mathbf{1 0 0}$ & $\mathbf{7 0}$ & $\mathbf{1 0 0}$ & $\mathbf{1 6 2}$ & $\mathbf{1 0 0}$ \\
\hline
\end{tabular}

As entidades relacionadas informaram se mantinham relações/ligações, mesmo que só de conhecimento, com outras entidades civis existentes nos territórios dos distritos de estudo, que desenvolvessem ações, projetos, programas destinados à melhoria das condições de saúde, qualidade de vida e enfrentamento da violência junto a jovens e adolescentes das regiões. A tabela 30 demonstra que mais de dois terços das entidades entrevistadas manifestaram possuir algum tipo de ligação, sendo essa relação mais significativa no distrito do Jardim Ângela do que no Grajaú.

Tabela 30 - Indicações de associações e entidades pelos entrevistados - Da Grajaú e Jardim Ângela- São Paulo, 2008.

\begin{tabular}{|c|c|c|c|c|c|c|}
\hline \multirow{3}{*}{$\begin{array}{c}\text { Indicaram } \\
\text { assoc/entidades }\end{array}$} & \multicolumn{4}{|c|}{ Distritos } & \multirow{2}{*}{\multicolumn{2}{|c|}{ TOTAL }} \\
\hline & \multicolumn{2}{|c|}{ Grajaú } & \multicolumn{2}{|c|}{ Jd. Ângela } & & \\
\hline & $\mathbf{N}$ & $\%$ & $\mathbf{N}$ & $\%$ & $\mathbf{N}$ & $\%$ \\
\hline Sim & 38 & 41,3 & 13 & 18,6 & 51 & 31,5 \\
\hline Não & 54 & 58,7 & 57 & 81,4 & 111 & 68,5 \\
\hline TOTAL & 92 & 100 & 70 & 100 & 162 & 100 \\
\hline
\end{tabular}

As entidades entrevistadas apontaram 259 associações, sendo 125 no Grajaú e 134 no Jardim Ângela, correspondendo, em média, a 2,3 associações por entidade entrevistada, conforme Tabela 31. 
Tabela 31 - Número de associações e entidades indicadas pelos entrevistados - DA Grajaú e Jardim Ângela, São Paulo, 2008.

\begin{tabular}{|c|c|c|c|}
\hline \multirow{2}{*}{ Associações e entidades } & \multicolumn{2}{|c|}{ Distritos } & \multirow{2}{*}{ TOTAL } \\
\hline & Grajaú & Jd. Ângela & \\
\hline Entidades entrevistadas (1) & 54 & 57 & 111 \\
\hline Associações indicadas & 125 & 134 & 259 \\
\hline Média de indicações & 2,3 & 2,4 & 2,3 \\
\hline TOTAL & 92 & 70 & 162 \\
\hline
\end{tabular}

(1) entidades entrevistadas que indicaram alguma relação

Os projetos, programas e ações desenvolvidas pelas associações indicadas, conforme Tabela 32, em última instância buscam tirar os jovens das ruas por meio de atividades diversas que preencham o tempo ocioso. A tipificação desses programas, projetos ou ações denota a orientação de cada um, dando um direcionamento mais específico no sentido da coordenação das atividades e sua motivação. Essas intervenções refletem a preocupação dos promotores para a mitigação dos problemas dos jovens e se voltam principalmente para a redução do risco de violência, referido por um terço das entidades, seguidas pelo foco voltado para a educação, cultura, desenvolvimento socioeducativo, que muitas vezes atende programas educacionais e culturais, a prática de esportes e o lazer, principalmente. 
Tabela 32 - Tipo de programas e ações, segundo entidades entrevistadas - DA Grajaú e Jardim Ângela, São Paulo, 2008.

\begin{tabular}{|c|c|c|c|}
\hline \multirow{2}{*}{ Tipo de programa } & \multicolumn{2}{|c|}{ Distrito } & \multirow{2}{*}{ TOTAL } \\
\hline & Grajaú & Jardim Ângela & \\
\hline Não resposta & 9,3 & 14,0 & 11,7 \\
\hline Redução do risco de violência & 24,1 & 42,1 & 33,3 \\
\hline Educacional & 31,5 & 28,1 & 29,7 \\
\hline Cultural & 31,5 & 19,3 & 25,2 \\
\hline Sócio-educativo & 9,3 & 21,1 & 15,3 \\
\hline Esporte e lazer & 20,4 & 10,5 & 15,3 \\
\hline Cidadania e defesa de direitos & 13,0 & 15,8 & 14,4 \\
\hline Promoção de saúde & 13,0 & 12,3 & 12,6 \\
\hline Profissionalizante & 11,1 & 8,8 & 9,9 \\
\hline Creche, berçario & 7,4 & 7,0 & 7,2 \\
\hline Educação sexual & 3,7 & 7,0 & 5,4 \\
\hline Artesanato & 3,7 & 5,3 & 4,5 \\
\hline Orientação familiar & 7,4 & 1,8 & 4,5 \\
\hline Distribuição de leite, alimentos & 5,6 & 3,5 & 4,5 \\
\hline Alfabetização & 3,7 & 3,5 & 3,6 \\
\hline Apoio psicológico & 5,6 & 1,8 & 3,6 \\
\hline Prevenção ao uso de drogas & 3,7 & 3,5 & 3,6 \\
\hline Promoção social & 0,0 & 5,3 & 2,7 \\
\hline Erradicação de trabalho infantil & 3,7 & 0,0 & 1,8 \\
\hline Ambiental & 1,9 & 1,8 & 1,8 \\
\hline Planejamento familiar & 0,0 & 3,5 & 1,8 \\
\hline Cuidado com idosos & 3,7 & 0,0 & 1,8 \\
\hline Recuperação de dependentes químicos & 1,9 & 0,0 & 0,9 \\
\hline Encontro de jovens & 1,9 & 0,0 & 0,9 \\
\hline TOTAL & 100 & 100 & 100 \\
\hline
\end{tabular}

Por meio de Análise de Correspondência AC, foram relacionadas as entidades que manifestaram ligações e o tipo de programa relativo às organizações citadas com o objetivo de identificar diferenças nos dois territórios analisados no estudo.

A AC é uma técnica multivariada para examinar relações geométricas do cruzamento, ou contingenciamento, de variáveis categóricas e permite avaliar relações entre variáveis categóricas ou entre categorias dessas variáveis. (Pereira, 2001)

As Figuras 18 e 19, respectivamente a AC do Grajaú e Jardim Ângela, mostram, no distrito do Grajaú, que as escolas têm um papel centralizador, atuando com diversos programas e ações, o que parece ser natural, uma vez que esta instituição dedica-se a apoiar o crescimento e desenvolvimento dos jovens e 
adolescentes. As demais entidades, como as associações, que compreendem as associações de bairro, comunitárias e assistenciais, têm vocação para a prática assistencial, principalmente relativa à distribuição de leite e à guarda de crianças (creches e berçários). Outros atores atuam no território, desempenhando papéis semelhantes, sem, entretanto desempenharem uma tarefa bem definida.

No Jardim Ângela o quadro se apresenta de forma um pouco diferente. Embora a escola tenha um papel relevante, ela divide as atenções com as entidades de saúde, que participam com intensidade na administração de programas dirigidos aos jovens. As associações desempenham, além da prática assistencial, uma função importante na alfabetização de jovens e adultos, como pode ser visto no diagrama abaixo. 
Figura 18 - Análise de correspondência - AC entre as entidades e o tipo de programa das associações indicadas - Grajaú

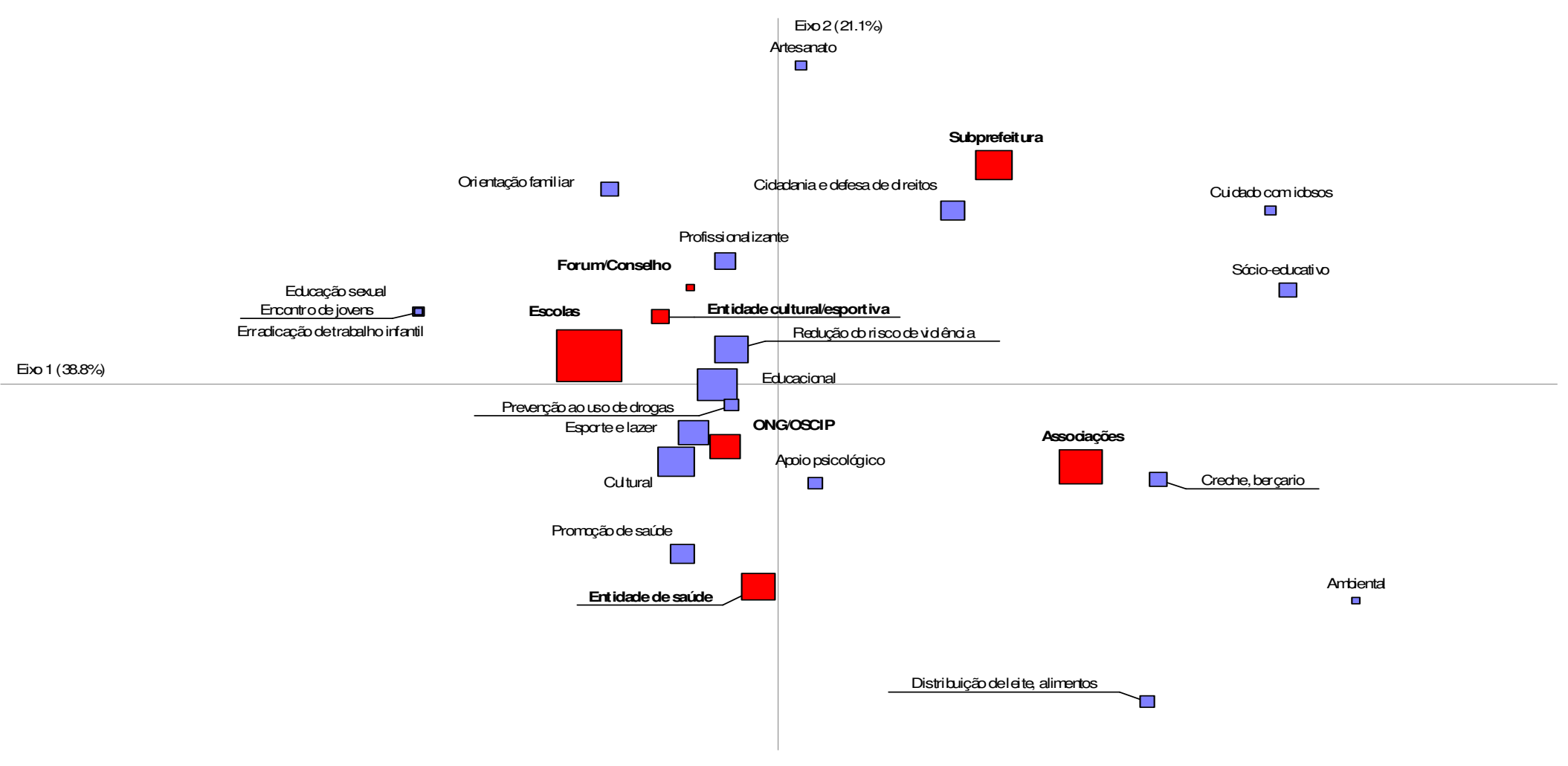


Figura 19 - Análise de correspondência AC, entre as entidades e o tipo de programa das associações indicadas - Jardim Ângela

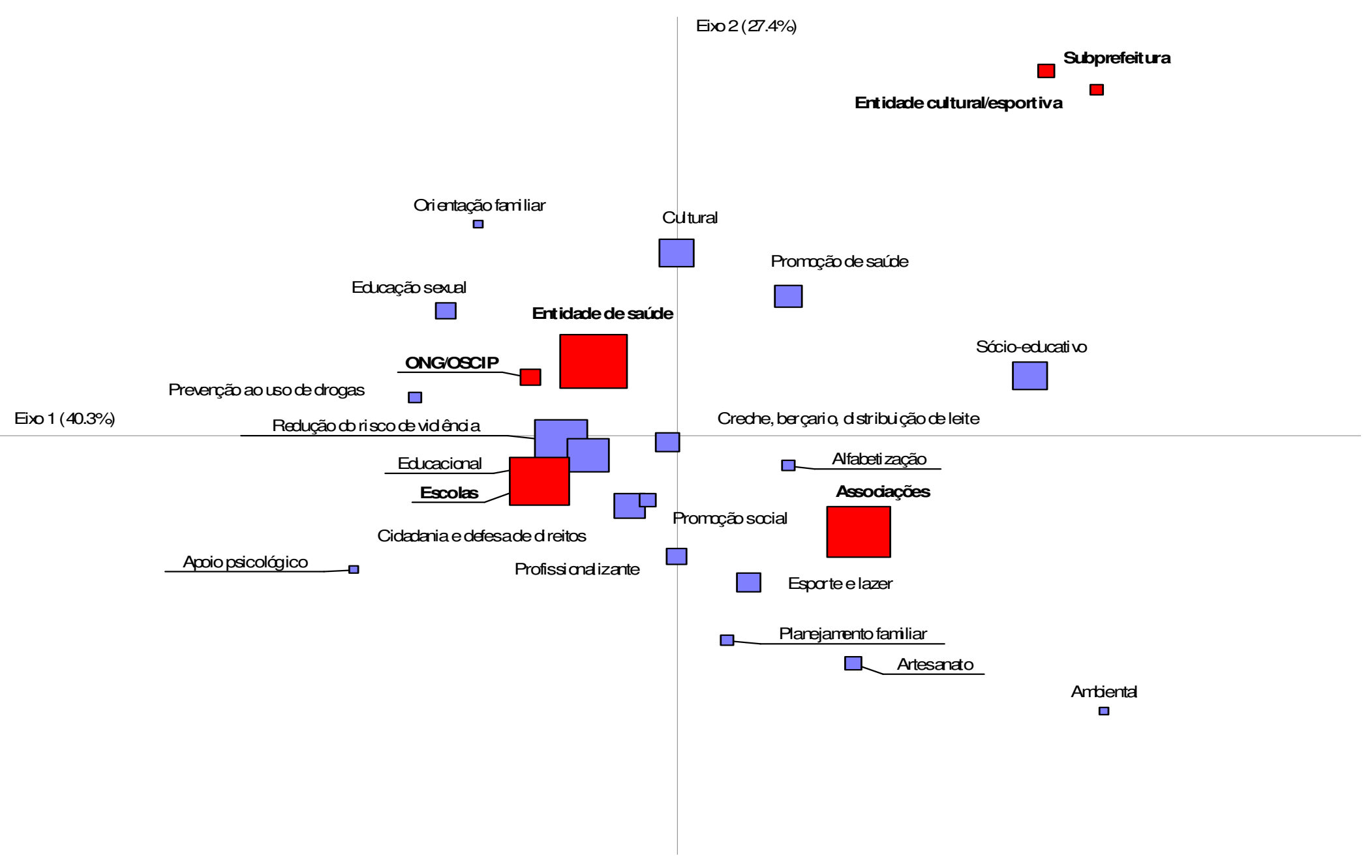




\subsection{AS ENTIDADES E SUAS RELAÇÕES}

A análise das 111 entidades entrevistadas e a rede social resultante do relacionamento entre esses atores e as 259 associações indicadas foi realizada com o programa Ucinet 6 - versão $6.130^{5}$. Construiu-se uma matriz de dupla entrada com as entidades entrevistadas e indicadas, distribuídas em linhas e colunas, atribuindo-se 1 ou 0 para caracterizar a existência ou não de relacionamento entre elas.

O exame do relacionamento considerou o conceito de centralidade. Esta idéia foi introduzida por BAVELAS em 1948, aplicada ao conceito de comunicação (FREEMAN, 1978). O conceito de centralidade é também correlato ao de poder, mas neste caso pode-se considerar, basicamente, a proeminência das associações na disseminação de seus programas, projetos e ações voltados para os jovens, ou seja, a sua importância no contexto do enfrentamento da violência entre jovens e adolescentes, e outros objetivos.

Por essa perspectiva, buscou-se identificar junto às associações locais o grau de centralidade que se apresentava no relacionamento entre outras associações existentes nos territórios, como se estabelece o relacionamento entre todos os atores e se é possível reconhecer grupos ou claques a que cada entidade está mais direta e fortemente ligada.

Analisando a rede social por essa vertente, verifica-se no sociograma, Figura 20, quanto a centralidade das associações destaca-se no Grajaú. Em um primeiro plano, o Circo Escola, o Conselho Tutelar e a Casa da Cultura seguem sem a mesma intensidade os projetos Guri e Anchieta. Saliente-se que para a formação da rede, a partir da ligação entre as entidades, as escolas são fundamentais, reforçando seu papel de articulação entre os diversos projetos existentes na região.

Quanto à formação de grupos ou claques, permite entender a estrutura social e o encaixe dos atores na rede social, uma vez que a claque é um subconjunto de atores que estão mais fortemente ligados entre si do que a outros que não fazem parte do grupo. Podem-se identificar pelo menos três representados pelas figuras de cor

${ }^{5}$ Borgatti, S.P., Everett, M.G. and Freeman, L.C. 2002. Ucinet for Windows: Software for Social Network Analysis. Harvard, MA: Analytic Technologies. 
preta e centrados no Circo Escola e Projeto Anchieta, um outro de cor vermelha centrado no Conselho Tutelar, Casa da Cultura e Projeto Guri, e um terceiro, identificado pela cor verde com menor centralização. Devem-se mencionar as figuras de cor azul, dispersas no sociograma, sem articulação entre si, representando ilhas de relacionamento.

Os grupos de cor preta, vermelha e verde estão articulados no território podendo-se imaginar a possibilidade de integração das diversas ações empreendidas de forma mais sinérgica. 
Figura 20 - Sociograma da rede de apoio da região do Grajaú.

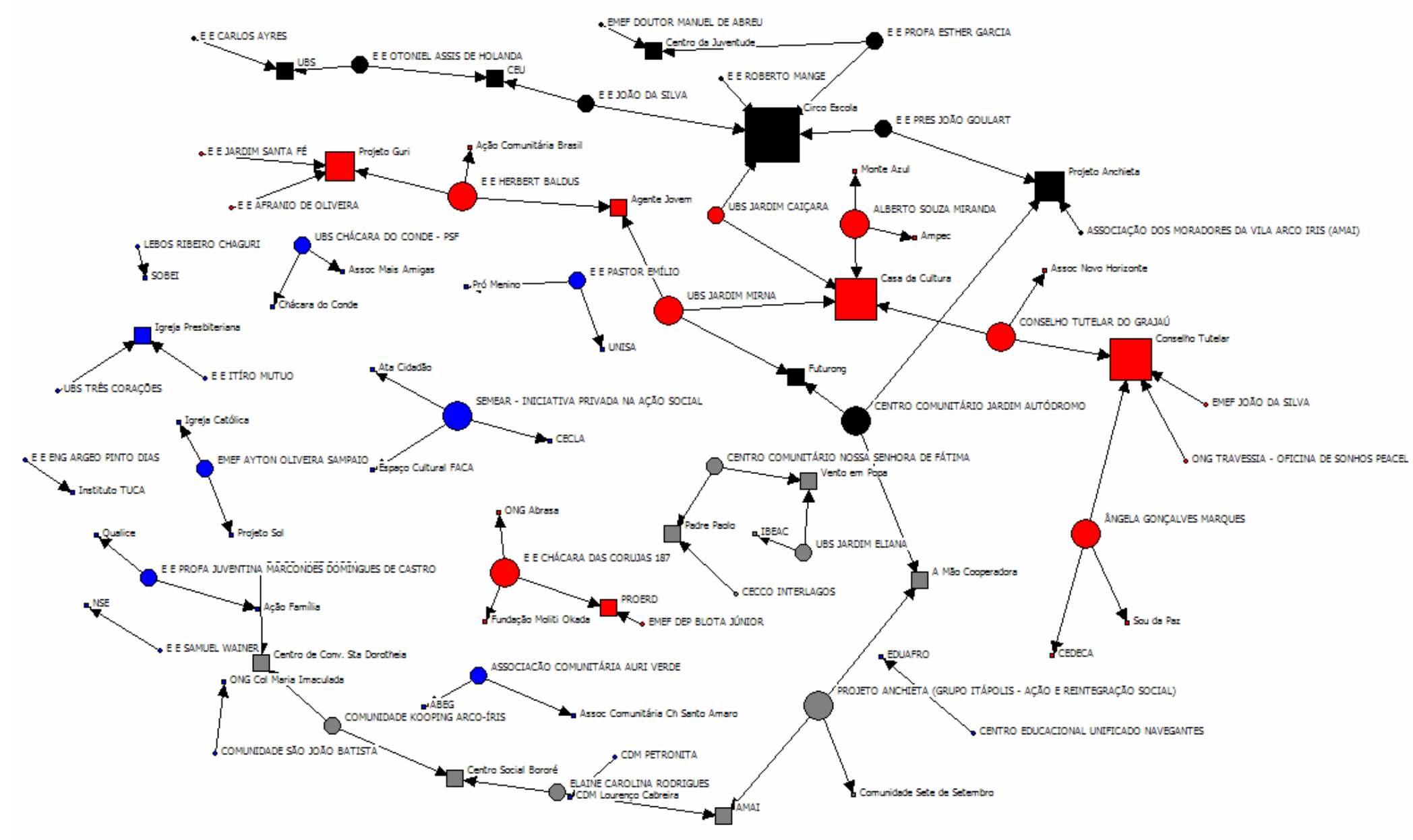


Analisando a rede social do Jardim Ângela, quanto à centralidade dos projetos, verifica-se no sociograma, Figura 21, que se destacam, em um primeiro plano, a Casa da Cultura, a Ancor, o Clube da Turma, Cardeal Rossi e os Santos Mártires, cujos programas são os protagonistas da ação na região.

Quanto à formação de grupos ou claques, podem-se distinguir claramente pelo menos três grupos: o grupo de cor azul, que se articula pela inspiração da Igreja Católica, que atua no território do Jardim Ângela de forma intensa, principalmente por intermédio da Associação dos Santos Mártires, como promotora e articuladora de programas. Há um grupo representado pelas figuras de cor vermelha, centrado na Casa da Cultura do M'Boi Mirim, e um grupo de cor verde, centrado no Clube da Turma e nas Unidades Básicas de Saúde - UBS. Devem-se citar as figuras de cor preta, que não constituem um grupo articulado, mas correspondem a ilhas isoladas.

Diferentemente da região do Grajaú, os grupos se relacionam a partir das associações existentes na região, ou por meio das UBS, como é o caso do grupo de cor vermelha, o que pode indicar maior capacidade de articulação de planos com ganhos de sinergia na ação. 
Figura 21 - Sociograma da rede de apoio da região do Jardim Ângela

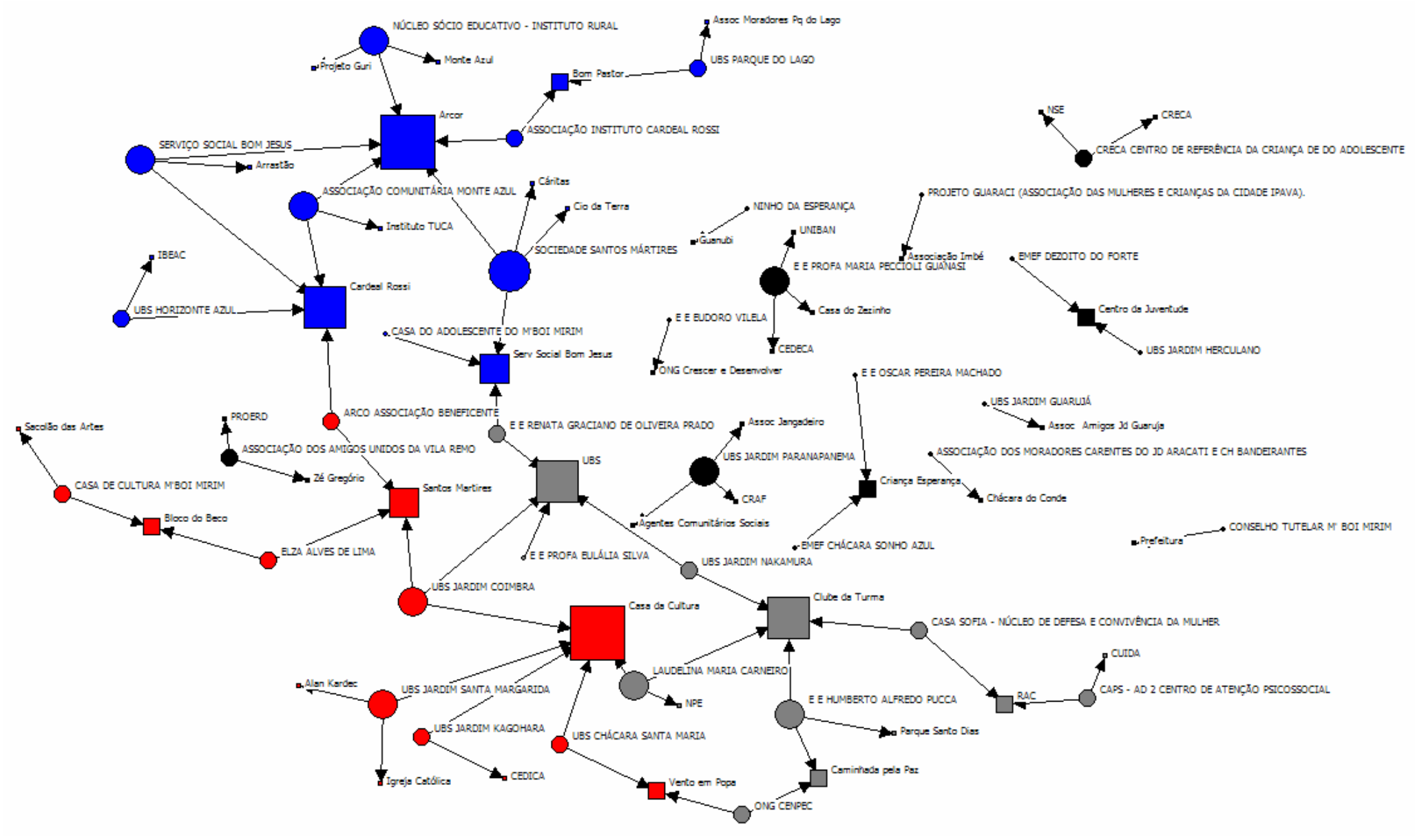


O estudo da relação juventude e violência, conforme demonstram os dados, desenvolveu-se em um cenário onde a vulnerabilidade social é grande e as condições oferecidas, em termos de serviços públicos, é precária. As instituições existentes e atuantes no local formam redes de relações de laços frágeis e implementam os programas assistenciais, em sua maioria, de maneira desintegrada, formando uma rede inconsistente e pouco efetiva para a proteção dos jovens que vivem nos dois distritos administrativos em estudo.

\section{AÇÕES COLETIVAS E POLÍTICAS PÚBLICAS NO GRAJAÚ E JARDIM ÂNGELA}

O grande desafio para nós, no lugar no mapa da exclusão, no lugar do mapa da violência, é criarmos um mapa de esperança, e acho que muitas dessas atividades tem dado esperanças,

(Liderança do DA Jardim Ângela)

\subsection{POLÍTICAS PÚBLICAS NA REGIÃO DO GRAJAÚ}

$\mathrm{Na}$ entrevista realizada com o gestor da subprefeitura da Capela do Socorro, foram identificados dois tipos de problema existentes na região: Infra-estrutura realmente você tem problemas de água, problemas de saneamento, problemas de pavimentação, e falta de equipamentos de cultura e de lazer, decorrentes da ocupação desordenada ocorrida na região.

\footnotetext{
"No Grajaú, nós temos 400 mil pessoas, e eu costumo dizer que isso equivale a duas Araraquaras, uma São José do Rio Preto (...) no Grajaú, como nós tivemos como ocupação selvagem da região durante 20, 30 anos, restou muito pouco espaço para implantação de equipamentos públicos, às vezes as ruas são muito estreitas, os loteamentos são irregulares e clandestinos então você tem o problema da regularização, as pessoas não têm estrutura, não tem documentação das suas casas, dos seus terrenos, porque os loteamentos regulares foram feitos à margem da Lei. A Lei previa que os lotes que tinham que ter entre 500, 600 e 700 metros foram feitos terrenos irregulares e clandestinos com 150 metros, 100 metros, então totalmente ilegal de acordo com a Lei. Então, além de serem ilegais, não havia possibilidade de regularização. E o que veio modificar isso foi a lei específica da Guarapiranga que foi aprovada no ano passado, regulamentada pelo governador no começo do ano passado, e que ela permite a regularização, impondo algumas condições".
} 
Segundo a subprefeitura, haverá um investimento em reurbanização na região, mas existe o problema da falta de espaços para instalação de equipamentos públicos.

(...) com verbas e recursos do PAC (Programa de Aceleração do Crescimento, do Governo federal), então nós vamos ter aqui em nossa região um investimento entre 1 milhão e 100 milhões em quatro anos, em reurbanizações. Mas é interessante para explicitar, nós temos ali no Cantinho do Céu, na península do Gaivotas, que vai ser uma área de urbanização, com 170 milhões de reais deixados lá, moram 65 mil pessoas numa área equivalente a Imilhão e 200 mil metros quadrados, que é parecida com o Parque do Ibirapuera, então nós vamos ter 65 mil pessoas morando numa área equivalente ao Parque do Ibirapuera. Só pra você ter uma idéia do adensamento. Eu tive recentemente com arquitetos (...) têm uma demanda de salas de aula no Grajaú, tem dinheiro e não acham terreno para implantar. (...) Quer dizer, uma demanda de 10 mil alunos com recurso pra atender, e tem dificuldades de achar terreno para implantar as escolas, tal grau de adensamento de ocupação que a região teve. Então, frente a isso, estão sendo tomadas algumas medidas.

Outra questão apontada pela subprefeitura é a necessidade de pavimentação, a revitalização e a construção de praças.

a segunda questão importante são as pavimentações, nós estamos realizando um grande (...) aliás o que nós estamos fazendo no Grajaú hoje corresponde a um terço do que está sendo feito na cidade de São Paulo. Nós devemos fechar só no Grajaú aí, em torno de 280, 300 ruas pavimentadas, em torno de $60 \mathrm{~km}$ de pavimentação só na região do Grajaú, nesse terceiro ano já foi feito a maioria disso, e vamos terminar o programa esse ano, que já tá com recurso, com a verba, com o encaminhamento. Então foi feito um grande trabalho de pavimentação, também de revitalização e construção de praças, pontos de contato, de lazer, de encontro entre as pessoas, que é uma questão fundamental e essas são as intervenções digamos, pulverizadas ou localizadas. .

$\mathrm{Na}$ área de cultura e lazer, a subprefeitura pretende fazer intervenções que considera mais significativas e de maior porte. A proposta é construir o "Complexo Cultural ou calçadão da Cultura”, no Jardim América, no começo do Grajaú, projeto prioritário que integra o Plano Local de Prevenção da Violência e Promoção da Convivência desenvolvido na região em parceria com o Instituto Sou da Paz, e o "Centro de Tradições Popular”, na região do Jardim Shangri-lá, mais no final do distrito, como ponto de encontro e de lazer para a população, conforme depoimentos: 
É nós estamos buscando fazer duas intervenções mais significativas, de maior porte. Uma, é a que nós chamamos de Pólo, ou Complexo Cultural do Grajaú, (...) ou "Calçadão da Cultura”. Lá nós temos o Centro de Cidadania da Mulher, tínhamos lá um sacolão, que transformaremos num teatro, estamos criando uma área coberta, um galpão ali no Tancredo Neves, um Espaço de Eventos e oficinas culturais, vamos incorporar nesse conjunto as duas praças que existem ali, e que vão ter atividades, numa delas inclusive nós estamos fazendo uma quadra coberta, fazer uma pista de skate, fazer várias atividades, um playground, tudo isso, tal, e temos dois CDMs na região. Então a idéia é justamente criar nessa região algo que não existe: primeiro, um Centro no Grajaú. Normalmente, acho que é fundamental pra vida das pessoas, pelo menos os comportamentos históricos mostram isso, no interior você tinha sempre a pracinha onde eles faziam o footing né (...). No Grajaú não tem nem supermercado, não tem praça, não tem shopping, não é mais supermercado, é shopping... isso, shopping, no Grajaú não tem nem Shopping. Então, quer dizer, a nossa idéia é fazer todo esse Complexo de oficina de cultura, de teatro, de cinema, de centro de cidadania da mulher, ligados por praças, ligados por calçadões, pra se tornar um local onde as pessoas realmente possam se encontrar, conversar, trocar experiências, andar, e ter uma alternativa diferente (...) porque a alternativa que existe ou algumas baladas bem perigosas, ou botecos (...). Uma entrevista da Folha no Grajaú mostrou que grande parte das pessoas entrevistadas pela Folha não conheciam cinema. Não existe cinema, aliás não existe cinema nem na Capela, em Santo Amaro só, shopping, em Santo Amaro só. E as pessoas, a maioria, nem chega lá. A maioria das pessoas fica restrita ao seu bairro, então você precisa numa região dessa importância, de 400 mil pessoas, você criar opções de lazer, opções de as pessoas se encontrarem, conversarem, tudo isso. Então a idéia desse Pólo, desse Complexo no Grajaú, é justamente essa função. Eu diria que o que existia no Grajaú antes (...) são os CEUs. Nós tínhamos dois CEUs no Grajaú: Navegantes e Três Lagos. Os dois CEUs, mal ou bem cumprem a função, eles têm o teatro, poder passar filmes, coisa desse tipo, abrem nos fins-de-semana para a comunidade, e realmente eles são muito valorizados pela população”.

A segunda proposta, considerada de impacto para a qualidade de vida da população, é o Centro de Tradições Populares:

outra proposta (...) nós temos lá no fundão do Grajaú, na região do Shangri-lá, nós temos um clube negro, um clube que foi o primeiro clube negro de São Paulo que se chama Os Aristocratas, que hoje tá decadente e semi-invadido. Nós estamos desapropriando, já encaminhamos (...), já existe um decreto de desapropriação, são 50 mil metros quadrados e a nossa idéia é fazer um parque com opções de esporte e de cultura nesse parque. (...) por ser uma área mais de verde, uma área de esportes, arborismo, coisas desse tipo, e a nossa idéia é também ali fazer uma espécie de Centro de Tradições Populares, quer dizer, como nós temos uma migração muito grande na nossa região, acho que aquelas pessoas pra se inserirem culturalmente é preciso o resgate das suas origens e tal, (...)a idéia é fazer festas temáticas, só que normalmente você tem o Centro de Tradições Nordestinas na Barra Funda, tem o Patativa aqui em Santo Amaro, que são particulares, mas é só comida nordestina e forró, só isso tem lá. Nós queremos trazer artesanato, trazer teatro pra nossa região, festas, algumas festas folclóricas na nossa região nós podemos inclusive fazer, então a idéia é ir além da arte culinária e da música, que também são muito importantes. Vai se chamar Centro de Tradições Populares. 
Com essas ações, a subprefeitura espera resgatar a auto-estima da população local e o sentimento de pertencimento ao território, conforme depoimento:

(...) a idéia, realmente, eu acho que essas coisas também subjetivamente geram uma autoestima maior em relação ao local que ele vive, é um lugar onde a pessoa pode ter experiências mais interessantes do que aquele cotidiano que normalmente ela tem. (...) para fazer obras melhores para ela começar a identificar o espaço onde ela vive, de uma forma mais favorável e talvez pensar com isso cuidar melhor desse espaço, se identificar com ele.

- Projetos para o enfrentamento da violência da subprefeitura Capela do Socorro

Além das propostas citadas para o enfrentamento da violência, a subprefeitura participa do Projeto São Paulo em Paz do Instituto Sou da Paz com a Prefeitura da Cidade de São Paulo e de uma parceria com a ONG Cenpec - Projetos Jovens Urbanos, do Agente Jovem Programa do Governo Federal, e do Pró-Menino, projeto de combate ao Trabalho Infantil em parceria com a Fundação Telefônica.

Especificamente, nesse período, para a questão da violência, dois projetos que apesar de serem pontuais (...) foi o trabalho do Cenpec chamado Jovens Urbanos, e tem também outro programa da Secretaria (...) que é o Agente Jovem, que trabalha essa questão da educação não-formal, acesso a Internet, a inclusão cultural e um trabalho também de combate ao Trabalho Infantil, que é o Pró-Menino, em parceria com a Fundação Telefônica. (...) são esses dois projetos Jovens Urbanos e o Agente Jovem que estimulam o jovem (...) estimulam a aprendizagem.

Para a subprefeitura, as ações e projetos em desenvolvimento contribuem para a qualidade de vida da população e, dessa forma, para o enfrentamento da violência na região. É ressaltada também a importância da presença do Estado intervindo para enfrentar a rede do crime organizado e ações conjuntas com a polícia civil, além da mudança de concepção da atuação da polícia, conforme depoimento abaixo:

Então, o enfrentamento da violência, eu acredito que essas medidas todas são formas de enfrentamento da violência, que em geral você tem que corroer a base que gera a cultura de violência, aí que você consegue fazer isso. Agora, nós temos desenvolvido programas como o Sou da Paz, temos feito contatos com a PM, temos trabalhado em diversas regiões, temos desenvolvido neste conjunto de ações e contato com a população procurar, inclusive sempre tratar a questão da violência (...) a cultura da violência. Na verdade esse trabalho que a gente faz é uma forma de enfrentar nas suas bases a cultura da violência e, por outro lado, na medida em que o Estado é visível, na medida em que o Estado começa a penetrar (...) na 
medida em que o Estado penetra, ocupa espaços, você vai tirando espaços que eram do crime organizado, as pessoas que acabam tendo um papel que o Estado deveria ter e não tem, então acabam se colocando como xerifes, pequenos prefeitos (...) e estabelecem uma rede de proteção dentro deles. Então, na medida em que o poder público vai penetrando nesses lugares você vai também abrindo espaços para que a influência desses grupos seja cada vez menor e diminua a violência. E a outra forma é procurar ter um contato estreito com a policia, a PM, a Policia Civil, para que realmente... até você tem normalmente uma cultura policial que pela história, é uma cultura especializada num processo repressivo. Eu acho que esse contato antes facilita um pouco que as culturas se interpenetram e você tenha condições até de uma assimilação (...) de uma força mais comunitária que perceba melhor os problemas da população e estabeleça formas de cooperação com a população"

\section{- Políticas públicas integradas e participativas}

De acordo com a subprefeitura, existem esforços para realizar um trabalho integrado na região, envolvendo as entidades e a comunidade, mas há dificuldades nesse sentido. Uma delas é a falta de representatividade das várias entidades da região. Uma das estratégias para a participação da população é a execução do Projeto Capela em Ação, desenvolvido nas micro-áreas da região, que visa desenvolver políticas públicas integradas e participativas.

A nossa prática do trabalho, desde o Capela em Ação foi trabalhar... toda a ação pública tem que ter o envolvimento da população (...) a questão da Guarapiranga são dezenas de discussões, a idéia nossa do Cine Clube, você vê. O Cine Clube, por que é um Cine Clube e não um cinema? O cinema é um lugar em que você vai lá e passa um filme onde a pessoa fica lá passiva, o cine clube é porque ele tem condições de promover ciclos, de debates sobre a mulher, sobre a violência, promover discussões, ele pode favorecer oficinas (...) então essa idéia no Centro de Tradições Populares é justamente envolver, existe na região inclusive, potenciais artísticos, (...) é sempre procurar, eu acho que em todas as nossas ações ter uma preocupação permanente de trazer as entidades, a população organizada e tal, e a população em geral até, que não responde ás associações, no sentido de se integrar os trabalhos que nós estamos fazendo. Nós temos tido uma resposta razoável (...) sempre temos contado com entidades representativos ao nosso favor e a gente bate na dificuldade de que as próprias entidades tem uma audiência não muito grande, não muito grande.. 
O depoimento abaixo ilustra a percepção sobre a falta de representatividade das entidades e evidencia as estratégias adotadas pela subprefeitura para participação da comunidade.

Tem entidades, lá no Cantinho do Céu tem entidade que lá ela deve falar, num lugar de 65 mil pessoas, ela deve falar com 500, 600, no máximo. Apesar de que no Grajaú tem muita entidade e em representatividade elas são minúscula, presidente, tesoureiro, secretário e mais umas duas ou três pessoas. Como estratégia de comunicação a gente sempre procura trabalhar em dois níveis: um com as entidades, e com as pessoas, que não venham através só da liderança, da entidade, ou coisa desse tipo.

\section{- A participação dos Jovens}

No que se refere à participação dos jovens nos projetos da região, existe a percepção de que eles participam, quando há espaço e estímulo. Embora os jovens tenham participado de algumas ações, ainda não corresponde ao esperado. Segundo o entrevistado, os jovens não se interessam pelas questões de infra-estrutura da região, o interesse da juventude é voltado para lazer e cultura. Há movimentos de participação em espaços públicos como o EJA - Educação de Jovens e Adultos e os Grêmios nas escolas:

Olha, eu acho que os jovens têm participado muito quando eles são estimulados (...) com o Agente Jovem, o Jovens Urbanos. Então, quando há espaços para eles virem, eles participam bastante (...) e quando bem estimulados, eles respondem bem a este chamamento mas em termos gerais, por bairros com 200 mil jovens, eu acho que o chamamento ainda é pouco (...) muitas escolas aqui não têm EJAs, que é o espaço de organização dos jovens, os que têm eu vejo que há uma movimentação, que eles estão discutindo o espaço público, o Grêmio (...) então tá havendo um certo desenvolvimento. (...) a impressão que dá é que quem se mobiliza por reivindicações de infra-estrutura são os mais velhos, eles (os jovens) não se interessam muito por reivindicação de asfalto, falta de luz, os jovens estão mais preocupados quando se fala em cultura, quando se fala em lazer -hip-hop, skate, grafite(...) é, você consegue uma mobilização maior e é até um problema porque sempre olho as lideranças de bairro e cada dia elas estão mais velhas (...) então você vê o mesmo pessoal, é difícil você ver alguém mais jovem ou mais novo, participando dessas ações.

\section{- Os principais problemas dos jovens}

$\mathrm{Na}$ opinião dos entrevistados os principais problemas dos jovens são as drogas, o desemprego e a falta de esperança: Eu acho que não são diferentes do conjunto... os problemas de droga, os problemas da oferta de drogas (...), da falta de emprego, das desesperanças, né... 


\section{- Opinião sobre os jovens}

Para o entrevistado, o futuro dos jovens depende das oportunidades que lhes são oferecidas e das escolhas que puderem fazer. Considera fundamental investir na formação e no futuro dos jovens, propiciando opções interessantes para que eles possam desenvolver o potencial que têm.

Os jovens são o que eles podem ser dentro do mundo que eles vivem.. Eu acho que é geral, aqui nesta região não é diferente das outras, principalmente o jovem, ele tem uma visão muito aberta, ele tem uma alma muito aberta pro mundo e o que ele vai ser depois vai depender muito do que acontecer, de quem entrar por essas aberturas. Então eu acho que o jovem, se a gente conseguir gerar essas situações que a gente tá vivendo, realmente é um momento de formação, um momento em que ele vai construir a maneira de ele ser no futuro, então, se o cara realmente não tem oportunidade nenhuma, nada, não sei o quê, o que ele vai ser, o que ele acha do mundo? Pode ser uma pessoa extremamente egoísta, fechada nela mesma, achando que ele resolve as coisas por ele mesmo (...), só tem inimigos a sua volta, (...) cada um na sua, ou realmente se mostrar pro mundo, pra vida, pra outras possibilidades, outras oportunidades. Acho que o jovem é um investimento fundamental agora você tem que dar opções interessantes pra essa abertura que ele naturalmente tem.

\section{- Potencialidades da região}

Apesar das dificuldades existentes no Grajaú, a região apresenta aspectos positivos, mas necessita de investimentos a fim de contribuir para a melhoria das condições de vida da população:

Então, se você pensar, você pode pensar em várias hipóteses: emprego e renda. A região do Grajaú é totalmente desprovida de oferta de emprego e renda. Com esse trabalho de revitalização da Guarapiranga nós esperamos gerar aqui uma área de emprego e renda compativel com a região de mananciais, que consiga ter emprego maior, de mão de obra, de coisas desse tipo. E quanto às atividades culturais, desses pólos culturais, você ter mais condições de as pessoas poderem aprender e colocar pra fora as suas... os seus talentos...suas vocações e tal, conseguir gerar espaços onde eles possam realmente trocar essas coisas aí (...) oferecer livro, incentivar a leitura, essas ações desse tipo. Acho que a idéia é envolver a região num pólo turístico (...). É, a Billings tem uma região muito bonita que é o Bororé, pra turismo né, mas é uma região ainda muito primitiva, então a idéia, nós vamos fazer um modelo na Guarapiranga, por que na Guarapiranga e não no Grajaú que talvez tá mais carente?, porque a Guarapiranga (...) ela é o reservatório mesmo...dali que sai a água que vai pra sua torneira, então realmente tinha que proteger esse manancial, era uma questão vital, urgente, fundamental proteger esse que é o grande manancial na região metropolitana de São Paulo... é o Guarapiranga, é o único manancial, não tem outro na capital então por isso é que ele tem que ser protegido. Mas agora a idéia é, a partir desse modelo do Guarapiranga, avançar pra Billings... inclusive como turismo, como lazer...as urbanizações vão estabelecer taxas de verde em volta da Billings.. 
Os investimentos referem-se também ao desenvolvimento de formas e espaços coletivos de participação, solidariedade e aquisição de conhecimentos para que se possa mudar a realidade e ter qualidade de vida:

Eu acho que a gente tem que, principalmente desenvolver formas de solidariedade, participação coletiva, eu acho que falta muito isso pro jovem, acho que utilizar esses pólos de atração como o Cine Clube, tudo isso, pra procurar fazer com que as pessoas se encontrem, conversem, discutam, participem, montem grêmios nas suas escolas. Eu acho que essa relação positiva, essa relação potente, vai, quer dizer, eu acho que é fundamental para as pessoas não se sentirem impotentes, que a realidade é uma droga e que realmente eles não têm como interferir nisso e que eles olham o futuro e vêem a mesma coisa. Eu acho que do ponto subjetivo, eu acho que é fundamental a gente instaurar uma certa capacidade de potência, as pessoas perceberem que é possivel melhorar, que é possível mudar as coisas, que é possível mexer na sua qualidade de vida, então eu acho que...e essas situações são ganhas coletivamente, né, você, isolado, tal, sozinho, você não tende a adquirir, não tende a ter essas satisfações, você precisa criar espaços coletivos, espaços de sociabilidade coletivos, pra que as pessoas possam ter informações além daquelas que vem da televisão, do boteco, né, espaços onde as pessoas possam interagir de outras formas.

\section{- Percepção sobre a violência na região}

Segundo os entrevistados, a violência na região está diminuindo e esta é uma tendência na cidade de São Paulo. Embora a subprefeitura não tenha indicadores precisos para analisar essa queda, a percepção que se tem é de que as ações realizadas na região têm contribuído:

Tem caído, de acordo com a polícia, tem caído. Eu acho que tem alguns fatores: o índice de violência baseado na criminalidade (...) há uma tendência de queda histórica na cidade de São Paulo que impacta todos os lugares, então é uma tendência de queda. Agora, como a gente não tem indicadores mais atuais, e a violência não é só o homicídio, eu tenho impressão de que as ações da subprefeitura tem tornado os espaços mais abertos e mais permeáveis então a gente, andando no Grajaú, você percebe que as pessoas melhoraram em termos de qualidade de vida, as ruas foram ordenadas, foram abertas, foram calçadas, asfaltadas, onde não existia passagem de ônibus, tá tendo, praças foram feitas, então apesar de não haver um indicador preciso pra ver isso, o Centro de Cidadania da Mulher, você consegue olhar eu acho que, a região, um pouquinho mais aberta.

Constata-se que os novos espaços públicos criados ou revitalizados, segundo o entrevistado, permitem uma convivência mais saudável, possibilitando diálogo, respeito e auto-afirmação, o que contribui para a redução da violência doméstica, bem como novas reivindicações para melhoria da qualidade de vida: 
Agora, outros problemas vão surgindo, à medida que a gente faz, que abre ruas num bairro, que asfalta, urbaniza, vem outro tipo de demanda aí eles querem (...) playground (...) aqui no Grajaú 10 praças foram feitas, ou 15 até (...) para melhorar a qualidade de vida das pessoa. A pavimentação mesmo, o testemunho que a gente tem das pessoas é que as pessoas saem no asfalto pra conversar, de fim de semana principalmente, não é carro que anda lá, são as pessoas, então elas passam a conversar, coisa que não faziam então realmente acho que conversar, socializar, ter experiências, falar das coisas, é uma coisa positiva à nível de enfrentar a violência doméstica, se auto-afirmar como pessoa, de saber um pouco mais dos seus direitos.

- O Projeto São Paulo em Paz: Plano Local de Prevenção da Violência e Promoção da Convivência do Grajaú

São Paulo em Paz é um projeto piloto municipal de segurança pública para a cidade de São Paulo em desenvolvimento nos distritos da Brasilândia, na zona norte, Grajaú, na zona sul, e Lajeado, na zona leste. O projeto foi viabilizado a partir da parceria entre a Secretaria Especial de Participação e parcerias da Prefeitura da Cidade de São Paulo e o Instituto Sou da Paz. A proposta do projeto foi originada pela preocupação da Prefeitura da Cidade de São Paulo com as altas taxas de homicídio e violência na cidade e do reconhecimento de seu papel na construção de uma cidade mais segura (INSTITUTO SOU DA PAZ, p.3, 2007).

O Projeto teve como objetivo elaborar um Plano Local de Prevenção da Violência e Promoção da Convivência por meio da participação comunitária e articulação intersetorial em cada um dos distritos selecionados. Os Planos trazem novas propostas e também propõem a articulação, complementação e fortalecimento de ações já desenvolvidas nos Distritos (INSTITUTO SOU DA PAZ, p.3, 2007).

O plano foi desenvolvido e duas grandes etapas. Na primeira etapa foi elaborado o diagnóstico em cada um dos distritos, contendo informações quantitativas e qualitativas sobre crimes, violências, programa de prevenção do poder público e da sociedade civil e percepções sobre o tema. Na segunda etapa foi elaborado o Plano contendo propostas prioritárias, identificadas pelos atores locais para prevenir a violência e promover a convivência pacífica nos distritos participantes do projeto. 
- Articulações para construir uma São Paulo em Paz

O grupo de gestão Estratégica do Programa realizou uma ampla articulação, com as Secretarias Municipais da Educação, Saúde, Assistência e Desenvolvimento Social e do Verde e Meio Ambiente para a implementação da ação de mediação de conflitos nos distritos da Brasilândia, Grajaú e Lajeado. Por meio dessa articulação, o Programa São Paulo em Paz envolveu a Defensoria Pública Geral do Estado de São Paulo e a Secretaria Nacional de Segurança Pública (Senasp), por meio do Programa Segurança Cidadã. A Coordenação Geral do Programa São Paulo em Paz também realizou uma série de reuniões em diferentes secretarias municipais e estaduais, visando definir ações prioritárias e estratégicas para a prevenção da violência e implementação das ações.

No dia 8 de agosto de 2007, foi realizado o Seminário São Paulo em Paz: Jogos de Mediação, em parceria com a Secretaria do Verde e Meio Ambiente e a Fundap - Fundação de Administração Pública. O evento ocorreu na UmapazUniversidade da Paz com o objetivo de discutir a mediação de conflitos, suas forma de sensibilização e replicabilidade. Os jogos de mediação são instrumentos para a simulação de situações-problema e resolução de conflitos.

\section{- O Projeto no Distrito do Grajaú}

No distrito do Grajaú, a primeira etapa do projeto ocorreu no primeiro semestre de 2007, quando foram constituídos grupos de trabalho e realizado o diagnóstico participativo. Na segunda etapa, no segundo semestre, foi elaborado e implementado o plano de trabalho. Para o ano de 2008 foi prevista a continuidade da implementação e consolidação do plano. Os compromissos assumidos foram o de promover a convivência pacífica e segura no Distrito do Grajaú, o de diminuir o envolvimento de adolescentes e jovens em situações de violência e e de reduzir os crimes de maior incidência e/ou maior impacto no distrito. 


\section{- Definição dos Projetos Prioritários no Distrito Grajaú}

O Programa São Paulo em Paz passou por uma revisão de estratégia para implementação. Foram selecionadas ações prioritárias dos Planos Locais para desenvolver projetos específicos, facilitando, assim, o processo de implementação.

Dentre as ações previstas no Plano, foram priorizada nove para implementação do Programa no Distrito do Grajaú. De todas as ações, a gente elegeu algumas ações prioritárias porque tinham muitas ações que não eram de governabilidade do Instituto Sou da Paz pra serem implementadas, e daí precisaria de uma parceria mais efetiva da prefeitura e que a gente tava com um pouco de dificuldade de implementar essas ações (Instituto Sou da Paz, 2007).

Essa escolha se deu devido aos trabalhos desenvolvidos pelos parceiros no território e também pelo seu impacto s na prevenção da violência e promoção de convivência pacífica, da adesão do poder público local e das parcerias para o desenvolvimento das ações.

As ações priorizadas foram: realizar o Curso de Orientadores Jurídicos Populares, promover a Mediação de Conflitos, como instrumento de resolução pacífica de conflitos, criar Pólos Culturais nos bairros do distrito, promover atividades culturais, esportivas e de lazer no período noturno, tornar as escolas espaços de prevenção de violência e promoção de convivência pacífica, criar mecanismos de aproximação entre jovens e agentes de segurança, ampliar a Rede de Telecentros no Distrito, gerar oportunidades educacionais, culturais e profissionalizantes, iluminar e efetuar reparos urbanos no entorno das escolas.

Várias reuniões do Comitê Local foram realizadas para discutir os avanços na implementação e os desafios do plano. Nessas reuniões verificou-se a ausência da participação da maioria das entidades, bem como a ausência dos jovens que integram a rede cultural, do Pró-Jovem e de outras entidades da região, o que indica a dificuldade de adesão ao Programa pelas dificuldades de diálogo com a subprefeitura, conforme mostram os depoimentos dos entrevistados.

A maior participação é do poder público representado pela subprefeitura e pela Secretaria de Participação e Parceira, da Secretaria de Desenvolvimento e Assistência Social com o Craf - Centro de Referência da Família, da Coordenadoria 
Municipal da Educação da Capela do Socorro e das ONGS que desenvolvem trabalhos na região, como o Instituto Pólis e o Cenpec:

(...) a gente tem dificuldade, por exemplo, pra adesão do programa, alguns parceiros, a gente tem investido muito na adesão de alguns parceiros até hoje apesar de o programa estar no Grajaú desde, desde o início de 2006. A parceria com a prefeitura é uma parceria difícil também, algumas questões de mediação mesmo entre subprefeitura e entidades locais pra discussão de alguns dos projetos, então às vezes a gente tem dificuldades de mediar algumas discussões entre a população e entidades com a subprefeitura (E-2).

Outra dificuldade refere-se à perda de contato com as entidades e às mudanças ocorridas na equipe que participou da fase do diagnóstico a gente se depara muito com entidades ou pessoas da comunidade que participaram da fase de diagnóstico só que acabou perdendo contato no meio do caminho, aí aparece na reunião e fala "ah, a gente não teve retorno", então teve muita coisa que foi feita nessa fase, que a gente não participou e não estabeleceu todos os contatos com as entidades, mas eu acho que grande parte dos grupos que participaram do diagnóstico estão com a gente agora e tinha jovens (E.3).

Para discutir o projeto da Casa da Cultura, que será no espaço em reforma no Parque América, com a transformação de um local que abrigará e um "complexo cultural", onde funcionará um Cinema. O Comite Local reivindica a participação e incorporação dos jovens que integram a rede cultural na região e também dos jovens que fazem parte do Projeto Jovens Urbanos. O Projeto Jovens Urbanos está em fase de intervenção e abrange 480 jovens. O Comitê considera a necessidade de identificar estratégias para que os jovens participem, tragam contribuições e discutam a viabilidade do projeto. A construção de casa de cultura é uma briga histórica no Grajaú e agora tem essa possibilidade, só que o jeito que a comunidade quer e as entidades querem participar é diferente do modo como a subprefeitura quer que eles participem, então a gente fica nesse meio do caminho (E.3).

\section{- Consolidação do Plano}

Em 13 de março de 2008, foi realizada, na subprefeitura da Capela do Socorro, uma reunião de planejamento para o ano corrente, visando consolidar as ações iniciadas com o Projeto Convivência e Segurança Pacífica em 2007 na região. 
O contrato, realizado entre o Instituto Sou da Paz e a Prefeitura do Município de São Paulo, tinha seu término previsto no final da gestão municipal de 2008. A proposta do Instituto Sou da Paz é que a subprefeitura e a sociedade civil assumam o trabalho.

\begin{abstract}
O nosso plano pra consolidação das ações é investir no potencial comunitário que existe no distrito, então, a gente quer investir em equipes técnicas nas escolas, a gente quer investir nos jovens, a gente quer investir pra que alguma coisa desse programa fique. Então, a nossa aposta é investir nas lideranças, essa vai ser nossa aposta na fase de consolidação, até porque pra nós nesse momento tá muito difícil investir no poder público local pra consolidação dessas ações por conta de ser um a no eleitoral, de possível mudança de partido ou não, mas de qualquer forma, o ano eleitoral ele tá impossibilitando um pouco nosso investimento nas secretarias municipais e nas subprefeituras então a gente vai investir na comunidade pra questão da consolidação da sustentabilidade do programa (E.2).
\end{abstract}

O Plano Local de Prevenção da Violência e Promoção da Convivência para o Distrito do Grajaú é avaliado como um trabalho inovador, e a equipe do Instituto Sou da Paz realiza o papel de articulador entre poder público e poder local. Eu avalio como um trabalho inovador, quer dizer, a gente que trabalha com poder público, com Secretaria, a gente sabe tem que fazer com que eles conversem pra atingir um objetivo comum é, de fato, um avanço e é um trabalho que eu vejo como um trabalho diferenciado por ser um trabalho intersecretarial.

Quanto aos projetos prioritários em execução, avalia-se que foi dada prioridade para ações voltadas aos jovens da região, visando ao enfretamento da violência e ao papel das ONGs como articuladoras, no entanto é ressaltada a dificuldade de diálogo entre as entidades, entre os grupos de jovens e poder público, a diversidade de ações pontuais e a falta de investimento:

Eu acho que, falando do programa, as ações pra combater a violência ligada a juventude e tal, a gente deu uma prioridade bem grande pra área dos jovens, desde o trabalho com as escolas até essa coisa de trabalho com pólos culturais, casa de cultura e tal. Agora, no Grajaú o que eu vejo são muitas ações, ações com grupos de jovens mesmo e de outras entidades, mas, até se dialogam, mas o que falta mesmo é investimento, muito, iniciativa tem de monte, o que falta é investimento. (...) É um distrito que tem muitas iniciativas de jovens. Eu acho assim, que eles, eles se conhecem, eles sabem o que um grupo faz o que outro faz, que algumas ocasiões eles pensam em coisas juntas, mas acho que são pontuais, talvez faltasse uma articulação maior e mais organizada entre eles. 
Quanto ao papel articulador das ONGS e os grupos de jovens:

(...) com entidades, ONGs que trabalham na região, e aí sim essa rede ela tenta fazer um trabalho articulado. Tem também o movimento Hip Hop Grajaú que reúne muitos jovens da região, não é uma coisa formal, eles não se reúnem mensalmente, mas eles se comunicam muito bem, sempre que tem algum evento, alguma atividade, quase todo mundo tá sabendo, aparece, não é nada formal, nada institucionalizado, também eles nem querem isos

A articulação com o poder público:

Acho que às vezes, é uma coisa interessante a gente, o pessoal, as entidades, a população vêem o nosso trabalho como um meio de tentar entrar, fazer um diálogo com o poder público local (...) eles tentam marcar com a subprefeitura então eles falam com a gente, eles percebem que a gente é uma ponte pra eles, pra os aproximarem mais da subprefeitura.

\subsection{AÇÕES COLETIVAS NO JARDIM ÂNGELA}

No ano de 2000, o Jardim Ângela, ficou famoso quando foi apontado pela Organização das Nações Unidas (ONU) como o lugar mais violento do mundo. $O$ título era resultado de uma taxa anual de 116,23 assassinatos para cada 100 mil habitantes, índice que subia para 200 por 100 mil quando calculado apenas sobre a população masculina entre 15 e 25 anos de idade, de acordo com o Mapa da Exclusão Social, organizado pelo Núcleo de Pesquisas em Seguridade Social da PUC de São Paulo e Programa de Pesquisas em Geoprocessamento do Instituto Nacional de Pesquisas Espaciais (INPE) ( Subprefeitura M'Boi Mirim, 2007).

Em 2002, o Mapa da Exclusão Social revelava que 19,8\% dos chefes de família moradores do distrito não tinham renda e apenas $1 \%$ tinha curso superior. $\mathrm{O}$ Jardim Ângela chegou a ostentar, na década de 1990, a triste posição de líder em mortalidade materna e um aumento de $40 \%$ da mortalidade infantil entre os anos de 1994 e 1999, quando a média estava caindo em toda a cidade (Subprefeitura M'Boi Mirim, 2007).

A carência de ações públicas levou a comunidade a se organizar de forma altamente reivindicatória; diversos projetos foram desenvolvidos na tentativa de tirar as crianças e os jovens das ruas e afastá-los das drogas e da violência a fim de melhorar das condições de vida da população da região.

Conforme uma liderança entrevistada, a história da mobilização da comunidade civil no Jardim Ângela começou no início da década de 19 70: 
O trabalho da Igreja Católica, a instrução das comunidades eclesiástica de base construiu aqui nessa região o que eu chamo de "comunidade civil organizada" que não existia, eu acho que isso foi o alicerce para quando nós chegamos em 1987 e chegamos em dois padres, e que já tínhamos um trabalho junto em Embu das Artes, então quando chegamos aqui já tinha um alicerce, já tinha um trabalho (...).E eu já conhecia bem a região antes de vir morar aqui eu já trabalhava em Embu das Artes e os padres que trabalhávamos juntos tanto no movimento contra a opressão nos anos 70 quanto em outros momentos das comunidades eclesiásticas base então já tínhamos um contato. Santos Dias que tinha sido assassinado em 1979 já era meu amigo de alguns anos então eu já tinha uma inserção nessa região desde o início dos anos 70, que ajudou quando eu vim para cá eu já conhecia a realidade dessa região.

Foi no início da década de 1980, segundo a liderança, que começou o trabalho da Sociedade Santos Mártires. Nessa época, com o crescimento do desemprego, as mulheres, que necessitavam trabalhar para ajudar em casa, não tinham onde deixar as crianças, então foram organizadas as creches pela Paróquia Santos Mártires:

(...) para uma região que cresceu em torno das fábricas nas Nações Unidas e no início dos anos 80, com uma industrialização, robotização, computadorização, aquela mão-de-obra barata virou sucata e aí é onde a grande onda de desemprego nos anos 80, durante o Governo Montoro, deixou essa região muito carente, e aí eu acho que iniciou, com o desemprego e o fechamento das metalúrgicas e muitas outras saindo do estado de São Paulo, vendo os dados, por exemplo, a Calói, que em 1980 tinha 5 mil trabalhadores em 1990 tinham 500 trabalhadores fabricando o mesmo número de bicicletas ou até mais e com menos trabalhadores e essa realidade também da mudança com o desemprego foi o que nós chamaríamos de independência das mulheres, como os maridos não arrumavam trabalho aí as mulheres foram obrigadas a trabalhar, ou como diaristas, ou como em diversos tipos de empregos e surgiu assim o lado bom e o lado ruim disso e aí surgiu a grande problemática das crianças, onde deixar as crianças, e acho que a sociedade diante disso, a Paróquia Santos Mártires, que já tinha a construção das igrejas e salões, que eram usadas mais aos finais de semana para catequese ou outras atividades assim mas que durantes a semana eram ociosos, por isso que começamos a trabalhar com essas crianças em um tipo de creches."

A Sociedade Santos Mártires foi criada em 1988 como braço jurídico da Paróquia. Começaram assim as primeiras atividades da Sociedade Santos Mártires, com a realização de convênios com órgãos públicos para organização das creches, mas sempre considerando que esta era uma obrigação do Estado. Com esta visão, ao mesmo tempo que eram organizadas as creches pela Sociedade, as mães eram conscientizadas a reivindicarem junto ao poder público creches e escolas na região:

(...) como a Paróquia não é pessoa jurídica nós criamos em 1988 o que chamamos de sociedade a Sociedade Santos Mártires para ser o "braço jurídico" da Paróquia e para poder fazer convênios como os parceiros públicos e para fazer as primeiras atividades que foram as creches e que também a creche foi a que nós mantivemos mas sempre defendendo aquela visão que essa obrigação era do estado, não era papel nosso assumir o papel do estado então sempre foi lado a lado um trabalho com as mães para reivindicar creches e isso se estende para escolas, etc... 
Sendo assim, outros projetos e ações começaram a ser desenvolvidos pela Sociedade Santos Mártires e diante da gravidade da situação da região, considerada então a mais violenta do mundo, as entidades locais foram chamadas pela Sociedade para juntos analisarem a situação e intervir visando mudar a realidade. Conforme a liderança houve boa receptividade:

(...) e nesse sentido o trabalho da entidade Santos Mártires foi como a gente chama de uma bola de neve, uma coisa puxando outra, o jovem sai da creche e aí nessa idade de 7 a 9 anos que começam os pequenos furtos, os pequenos roubos, entram no tráfico para serem usados como "aviõezinhos" e nesse sentido, chegamos em 1996, quando a região foi declarada a região mais violenta do mundo, passando de Cali na Colômbia, que em 1995 tinha 80 assassinatos por 100 mil habitantes, o Jardim Ângela em 1996 tinha 120 por 100 mil habitantes, e acho que aí foi um desafio para nós e aí talvez nós demos um novo passo e convocamos todas as entidades da região para sentarmos juntos e analisar essa realidade e vermos como que podíamos intervir na questão da violência. Não só nos números mas também os padres na região são chamados para enterrar os mortos, rezar missa de sétimo dia, consolar as famílias e de uma forma ou de outra nós estávamos muito envolvidos nessa realidade toda e não bastava ficar só rezando e de modo especial a maioria das vítimas nós podemos dizer que são jovens de 14 a 25 anos de idade e aí tomamos aquela iniciativa de chamar escolas, diretores de escolas, entidades, outras igrejas e graças a Deus tivemos muita receptividade e que motivamos pessoas a participarem e a primeira proposta daquela vez, enquanto todos estavam recuando, dando mais espaço para o que era ruim a gente tinha analisado e definido que tínhamos que colocar a bandeira da vida e da paz."

Em 02 de novembro de 1996, foi realizada a primeira Caminhada pela Paz na região do Jardim Ângela. A proposta da Caminhada desencadeou diferentes emoções na população; no entanto, apesar do medo, houve adesão da comunidade e cobertura da imprensa:

(...) e partir daí, isso foi em agosto de 1996 e marcamos a Caminhada pela Vida e pela Paz até o cemitério São Luis, onde estavam sendo enterrados os dois lados da violência, nós podemos dizer e marcamos para o dia de finados, dia 02 de novembro de 1996. Quando iniciamos e divulgamos aquela ação, a reação do povo era interessante, muita gente vinha implorar a gente para não entrar nessa que era arriscado, perigoso e que iria colocar a vida da gente em risco e mil e outras coisas nesse sentido mas como éramos um grupo grande mantivemos a proposta e graças as Deus, naquela primeira caminhada tivemos em torno de 5 mil pessoas, como uma boa cobertura da imprensa e acho que o que era mais importante era essa participação da região e isso deu um grande incentivo para a gente que não estávamos sozinhos, que tínhamos que ir a diante e a partir daquela caminhada chamamos de Fórum em Defesa da Vida pela Superação Violência. 
Dessa forma, foi criado no Jardim Ângela o Fórum em Defesa da Vida pela Superação Violência que desde 1996, na primeira sexta-feira de cada mês e doze anos depois, dificilmente tivemos uma reunião com menos de 50 pessoas então é uma coisa que pegou e continua atuando até hoje ( liderança) .

- Os projetos e ações integrados desenvolvidos na região

Iniciaram-se, com a constituição do Fórum em Defesa da Vida, com o apoio do Centro de Defesa de Direitos Humanos de Campo Limpo e da Sociedade Santos Mártires, que depois assumiram a liderança do Fórum, a integração do poder público e sociedade civil e constituição de uma rede da qual participam, entre outros, a Subprefeitura de M'Boi Mirim, polícia civil e metropolitana, Secretaria do Governo, Ministério Público, Universidades, Secretaria da Municipal da Saúde para desenvolvimentos de projetos e ações na região, que segundo a liderança entrevistada, tem conseguido modificar a situação da região:

(...) nós sempre preocupados com uma integração, tanto com polícia civil, militar e agora a metropolitana, uma integração com o Ministério Público, uma integração com o poder constituído, como no caso a subprefeitura e a Secretaria de governo e graças a essa interação conseguimos inverter e acima de tudo criamos uma rede em que um complementa o outro, e acho que reconhecendo isso e criando diversas ações, como na questão das drogas por exemplo, conseguimos em parceria com a Unifesp, Escola Paulista de Medicina criar uma unidade comunitária de álcool e drogas, que tem feito muito atendimento, marcado muita presença, agora conveniada com a Secretaria de Saúde..

Foi criada a Casa Sofia, que oferece atendimento às mulheres vítimas da violência doméstica, por meio de orientação psicológica, jurídica e social, o Cedeca Centro de Defesa da Criança e do Adolescente, cujo trabalho desenvolvido é dirigido para os jovens em situação de risco e em liberdade assistida e projetos de alfabetização:

\footnotetext{
A violência escondida que chamamos de violência doméstica; foi criado um trabalho como a Casa Sofia, para combater toda essa violência doméstica e aí entra a questão da criança e do adolescente; foi criando o CEDECA (Centro de Defesa da Criança e do Adolescente) $e$ outros trabalhos que visam redescobrir os adolescentes na comunidade para jovens $e$ adolescentes em situação de risco, um projeto que foi pioneiro inclusive, um trabalho entre o estado e o município para acolher, apoiar e dar uma perspectiva para estes adolescentes e jovens ou fora da escola ou em situações de risco ou também liberdade assistida isso em parceria com muitas outras associações amigas de bairro, sociedade, e aí dando força também a questão da alfabetização de adultos e atividades que se tem que caminhar ao lado para criar um espírito de valorização da vida e graças a Deus.
} 
Uma das ações que teve êxito na região foi a implantação das bases da Polícia

Comunitária:

Eu acho que a primeira coisa quando se discute violência é que precisamos de mais polícias $e$ aí a gente tinha que discutir que tipo de policia, reconhecendo que essa região tinha muita violência policial também nos anos 80 e 90, de modo especial o famoso cabo Bruno, em que a região dele era aqui e a partir dai iniciamos uma discussão sobre que tipo de policia queremos e levantamos a proposta para a Secretaria de Segurança Pública da implantação de uma policia comunitária e que levamos para o Secretário de Segurança que a acolheu e o próprio secretário, José Afonso da Silva, veio aqui fazer diversos seminários conosco sobre violência e por fim, em 1998 foram implantados as bases comunitárias da policia e que deu um outro olhar para a policia.

$\mathrm{Na}$ área da saúde, após 12 anos de reivindicação, a população conseguiu a construção do Hospital de M' Boi Mirim, que trouxe perspectivas para a região. Segundo a liderança, os números mostram que a violência tem diminuído na região e isto se deve à integração e à somatória de pequenas ações desenvolvidas:

nesses doze anos, por exemplo, na área de saúde, sempre se coloca que a causa morte eram causas externas e não se tinha nem sequer um pronto-socorro na região, por isso a luta pelo hospital M'Boi Mirim, que esses dias foi inaugurado e o pronto-socorro já está funcionando na região - eu acredito que os números que nos dizem agora que são 130 assassinatos por 100 mil habitantes que chegamos em 1998 tem sido invertido para mais ou menos 30 assassinatos por 100 mil habitantes, que é uma grande queda, que coloco que isso se deve a uma interação de muitas pequenas atividades que foram colocadas e que tem dado muitos resultados; eu acho que essa interação entre diversos órgãos, e mesmo assim, pode parecer um fato simples mas a própria questão da construção do hospital, mesmo sem funcionar, mas criou uma perspectiva na região.

Para a liderança o desafio é em vez do mapa da exclusão, do mapa da violência, criar o Mapa da Esperança:

(...) como eu costumo dizer, eu acho que o grande desafio para nós, no lugar no mapa da exclusão, no lugar do mapa da violência, para criarmos um mapa de esperança e acho que muitas dessas atividades tem dado esperança, é onde o povo tem onde recorrer, onde ter uma perspectiva de dias melhores, que eu acredito ter mudado um pouco a realidade, muita gente mesmo comenta quando começam a comparar entre os anos 90 e agora com o fim dessa década de um novo milênio criou-se a sensação de medo então somando tudo isso eu diria que tem sido uma caminhada muito positiva e graças a Deus tem salvado muitas vidas e tem colocado o valor da vida como bandeira, não sei se estou me enganando mas eu sinto isso, eu acho que tem coisas como a caminhada que continua até hoje que chegamos a ter 25 mil pessoas, que continua no dia, acho que são ações que vão colocando a bandeira da paz. e vai juntando e somando forca com muita gente. 
$\mathrm{Na}$ Sociedade Santos Mártires existe uma rede de projetos. São aproximadamente 30. Dentre eles, conforme a liderança entrevistada, destacam-se:

\begin{abstract}
04 creches, quatro núcleos sócio-educativos, um núcleo de proteção especial, Casa Sofia, CEDECA, Centro de Referencia da Criança e do Adolescente - CRAC, Casa Abrigo Rainha do Sol, CAPS-Centro de Apoio Psicossocial, que tem três projetos: moradia assistida e outro que cuida de crianças, filhos de dependentes químicos. Temos um trabalho com deficientes físicos, temos outro trabalho com deficientes físicos e mentais. Temos uma casa chamada Ninho de Esperança que dá um apoio para crianças e deficientes, (...)reciclagem o lixo para dar uma sustentabilidade para os dependentes que estão saindo do vício porque com a reciclagem do lixo eles podem se sustentar; temos uma casa também acolher e abrigar as mulheres vítimas de violência; também tem o Centro de Referencia à Família, que é um trabalho com famílias então a própria Sociedade Santos Mártires já é uma rede de trabalho.
\end{abstract}

Entre os principais colaboradores da Sociedade Santos Mártires, a liderança cita a Prefeitura, que atua por meio das Secretarias Municipais, Universidades, Fundação Abrinq e, em especial, os alunos dos projetos:

os grandes colaboradores que temos, em especial, são os próprios alunos de cada projeto, cada projeto é um trabalho grande e cada um tem sua vocação, uma missão, e como também temos como missão dos Santos Mártires ser uma chama de esperança nessa região do Jardim Ângela através de ações que promovem para crianças, adolescentes, jovens e adultos promovendo a cidadania e temos conseguido grandes parceiros, acho que os maiores parceiros que temos são os convênios dos projetos com a prefeitura e a maioria desses projetos é conveniados com outras Secretarias, Secretaria da Saúde, Secretaria de Participação, Secretaria de Educação...devemos ter em torno de 30 salas de alfabetização e temos uma parceria com a empresa Camargo Correia, tivemos uma grande parceria na área de jovens e adolescentes com a Telefônica, nos ajudou muito, Abrinq também colaborado bastante na Casa Abrigo, mas realmente estamos deficientes de parceiros de peso, e criamos muita dependência da Prefeitura, do poder público (...) Um grande parceiro que não tem sido financeiro, como por exemplo, para álcool e drogas, é a UNIFESP, temos uma parceria muito boa, inclusive estão realizando pesquisas, outro que também não é financeira, que é a UNISA, (...) e que são parceiros importantes também, a PUC, (...) o serviço social da UNISA....

\title{
- A rede do Jardim Ângela
}

O Fórum em Defesa da Vida é uma rede composta de várias entidades do qual se originaram diversos Fóruns que atuam em rede para conhecer e intervir nos problemas da cidade e da região:

Essa rede, (...) o próprio Fórum em Defesa da Vida já se tornou um guarda-chuva de diversos outros fóruns, como tem os Fórum das Mulheres, o Fórum da Criança e do Adolescente, o Fórum da Educação, o Fórum da Inclusão, o Fórum das Organizações Sociais, deixa eu ver se tem outros, já são cinco fóruns em defesa da vida, e que todos se articulam dentro do Fórum em Defesa da Vida, porque o próprio Fórum em Defesa da Vida já é uma rede de entidades e escolas e a própria rede de fóruns que se interligam com outros fóruns pela cidade, inclusive nós estamos empenhados agora, realizamos aqui o terceiro 
Fórum Social Sul, olhando o lado sul de São Paulo, e tivemos a participação, num final de semana concentrado, como tema um pouco como foi o Fórum Social Mundial porque tem participado uma medida de 10 mil pessoas e agora estamos empenhados no fórum em São Paulo, que vai se realizar, aliás já está se realizando a medida que pensamos em propostas para a cidade de São Paulo mas as plenárias finais serão dias 15 e 18 de maio no SESC Vila Mariana, para juntar propostas para ser uma cidade justa e sustentável então é uma rede que pega toda cidade de São Paulo, não é só olhar para o umbigo da gente, a gente tem que olhar a cidade também.

\section{- Dificuldades que afetam a vida dos jovens do Jardim Ângela}

$\mathrm{Na}$ opinião da liderança, o principal problema que afeta a vida das crianças e jovens na região são: a qualidade da educação, a falta de equipamentos escolares e creches e a necessidade de um tratamento personalizado e humanizado nas creches e escolas voltadas para as crianças.

Eu diria isso, de primeira mão, a questão da educação, a questão da qualidade da educação nas escolas, falta de creches, falta de educação infantil, enquanto tudo isso leva ao abandono porque os pais são obrigados a trabalhar - uma das grandes problemáticas aqui são as famílias incompletas, se eu não me engano, no mapa de exclusão de 2002, 70\% das famílias eram de um pai só ou uma mãe só, a grande maioria só da mãe, ou com avós, então a desintegração da família tem que ser substituída pela comunidade, pela questão das creches, de escolas, as crianças tem que ser acolhidas e valorizadas e também eu diria de um jeito personalizado porque eu fico preocupado, por exemplo, como se sente uma criança de 2 ou 3 anos, colocada numa creche com mais de 300 crianças, com outros tantos jovens adolescentes, totalmente despersonalizado, eu imagino uma criança...quando eu volto atrás, penso nos meus 3, 4 anos de idade ter sido colocada numa situação dessas é muito difícil então eu me preocupo muito com essa despersonalização da sociedade e não humanizando a criança e as conseqüências que isso tem no futuro da criança.

Há ainda na opinião dela, a falta de perspectivas, o desemprego, as drogas, a

luta pela sobrevivência e a necessidade de investir na educação:

(...) a falta de perspectiva, a falta de emprego que a droga vem fazer assim, falta de estudo, que é criminal, é um crime o que está acontecendo na área da educação; a falta de oportunidades e menos condições de dinheiro porque tudo é um círculo vicioso, as condições de casa, de emprego, situação familiar, eu acho que são essas coisas: educação, perspectivas, oportunidades e a falta de dinheiro no bolso, que é o desemprego da família, e a luta pela sobrevivência ensina muitas coisas erradas e muitas certezas, a luta pela sobrevivência faz isso". 


\section{- Propostas}

Diante da complexidade dos problemas que afetam os jovens, é destacada a necessidade de se oferecer bolsas de estudo e trabalho para afastá-los do caminho do tráfico e da violência. Neste sentido a população reivindica que o hospital de M'Boi Mirim torne-se um Hospital Escola e que haja investimento na formação dos jovens, pois há falta de profissionais de saúde para os equipamentos da região devido a distância. $O$ investimento em transporte também se faz necessário, uma vez que também é um problema na região:

Olha, é uma situação complexa, mas eu prefiro dizendo a verdade, se não tem emprego, quais são as perspectivas o que quer um jovem de 15, 16 anos, sem um dinheirinho no bolso, como vai namorar, como vai...eles ficam de olho nos Nikes, nos Timberlands, nos tênis dos outros, etc.. então a única saída é entrar no tráfico, entrar para trabalhar na "firma" como diz a molecada, então não basta falar apenas em estudo, enquanto está estudando também precisa de um dinheiro para viver a vida pois não é só do estudo que se vive o jovem então os pais têm que entender, com os baixos salários, o que os jovens fazem aos finais de semana? Então temos que investir na questão de bolsa estudo na região. Por outro lado nós estamos brigando para que o hospital criado seja hospital-escola, nós precisamos investir em profissionais da saúde, senão vai ser pior daqui há 10 anos, pois falta profissionais e as pessoas não querem se deslocar para vir para regiões distantes como aqui, transporte, e ai temos que capacitar os jovens - desde que começamos a briga pelo hospital estamos querendo valorizar profissionais nessa área e não está sendo feito nada ainda.

\section{- Ações civis públicas}

$\mathrm{Na}$ região foram realizadas duas ações, chamadas de Tribunal civil promovendo ações civis públicas, para que o poder público atendesse às reivindicações da população. O primeiro foi para a área da saúde e segurança em 2002. Em outubro de 2008 foi realizado o segundo Tribunal Público para a área de lazer e cultura, mas passaram-se seis meses e, segundo a liderança, as reivindicações não foram atendidas. Está previsto um terceiro tribunal para cobrar as ações do poder púbico:

Em 2002 nós estávamos em um momento muito difícil e cansados de promessas e aí pensamos: -Vamos fazer valer a lei! Ficar só na caminhada, escutando promessas para nada sair e na época fizemos o que chamamos de tribunal popular, mas a primeira proposta era ação civil pública porque os números colocavam os assassinatos aqui da região como genocídio. Genocídio é contra jovens, negros e pobres e juntamos um grande número de advogados e ver quem era responsável: é o abandono dos poderes públicos pois sempre colocávamos que os responsáveis eram o abandono do poder público e em segundo lugar a dependência química, então resolvemos analisar os dados e responsabilizar o estado e aí nós 
temos que especificar, criamos duas áreas, a área de saúde e segurança, e na época tínhamos seis postos de saúde para todos o distrito do Jardim Ângela, tínhamos, na área da segurança, duas bases comunitárias, com 30 policiais e aí, diante desses dados resolvemos reunir os advogados e reunir, ir na justiça, envolver a população e fizemos o que chamamos de tribunal popular. Os objetivos eram envolver a população e o governo, dando um aviso para eles; eram convidados os devidos Secretários, Secretário de Segurança, Secretário de Saúde, e foram apresentados todas as causas como se fosse um julgamento, tínhamos juiz de verdade, tínhamos o Ministério Público e tinha os advogados de defesa e o governo era colocado como réu, e tinha a cobertura da imprensa. Eu me lembro que um dos dados que eu coloquei na área da segurança, porque uma cidade pacata do interior tem 200 policiais para cada 100 mil habitantes e no Jardim Ângela tem 30 policiais para 300 mil habitantes, enfim, o resultado que foi feito, condenado, o juiz condenou deu seis meses para cada Secretaria tomar algumas providencias senão íamos entrar como uma ação civil pública que já tínhamos entrado com outra ação civil pública contra o governo, contra a prefeitura, quando na área do esporte, aqui perto, no Parque Independência e mais tarde ganhamos a ação civil pública e a Prefeitura foi condenada a construir um espaço que já está funcionando.

Na área da saúde, Eduardo Jorge, logo em seguida, acho que isso foi em abril de 2002 declarou como utilidade pública a área do hospital e os postos de saúde saíram de6 para 18 e foi implantado programas para famílias na mesma época; a segurança alugou um prédio e fez a nova companhia de policia e até o fim do anos tínhamos 500 policiais aqui na região; nós conseguimos muita cobertura da imprensa também com esse tribunal popular.

Em outubro do ano passado fizemos outro tribunal para promover mais ações públicas em áreas marcadas pela juventude que se resume em cultura, lazer, em todo Jardim Ângela não existe uma ação voltada para isso, lidar com a Secretaria do Trabalho e da Educação também está nisso por causa de falta de espaços, e foram obrigados a tomar providencias dentro de seis meses então eu acho que a gente tem que usar a lei e fazer com que ela seja cumprida. Já fizemos dois tribunais, estamos agora promovendo mais ações civis públicas, passaram-se seis meses e não fizeram nada, nem na cultura, nem na saúde, então vamos entrar com uma ação civil pública até o fim do mês.

Conforme depoimentos da liderança há uma intensa mobilização das organizações sociais e grupos organizados que têm levado a uma reconhecida diminuição dos índices de violência na região. Há um esforço integrado na região, para que os índices se aproximem da média da cidade.

\subsection{POLÍTICAS PÚBLICAS DA SUBPREFEITURA DE M'BOI MIRIM}

\subsubsection{Projetos e Ações da Subprefeitura de M'Boi Mirim}

Conforme o documento fornecido pela Subprefeitura de M’Boi Mirim, a proposta de Políticas Públicas para o Desenvolvimento Regional de M’Boi Mirim é resultado da avaliação dos projetos dos Pólos de Desenvolvimento Social, realizados em 2006 e tem por fundamento: a integração de ações governamentais; as iniciativas da sociedade civil organizada, a iniciativa privada e o incentivo à participação popular. Visa à conjugação de esforços para a implementação de ações culturais, 
político-econômicas e socioeducacionais que impulsionem o desenvolvimento local e a melhoria da qualidade de vida da população da região.

O documento deixa clara a necessidade de a Subprefeitura implementar e coordenar novas ações, integrando o poder público e a comunidade. Conforme a Lei n. ${ }^{\circ} 13.399$, de $1 .^{\circ}$ de agosto de 2002, que dispõe sobre a criação de Subprefeituras no Município de São Paulo.

Referindo-se à Lei citada, o documento destaca dois artigos: o artigo 5. ${ }^{\circ}$, cuja atribuição das subprefeituras é: "atuar como indutoras do desenvolvimento local, implementando políticas públicas a partir das vocações regionais e dos interesses manifestos pela população;" e "facilitar a articulação intersetorial dos diversos segmentos e serviços da Administração Municipal que operam na região." E o Art. 9. ${ }^{\circ}$, que estabelece a competência do subprefeito: "coordenar técnica, política e administrativamente esforços, recursos e meios legalmente postos à sua disposição, para elevar índices de qualidade de vida, observadas as prioridades e diretrizes estabelecidas pelo Governo Municipal".

Os objetivos apresentados na proposta da Subprefeitura são:

- "Incentivar a mobilização e participação dos atores sociais que compõem as comunidades no processo de debates, levantamento e implantação de propostas para o desenvolvimento local e superação dos problemas da região.

- Estabelecer uma relação mais transparente e próxima entre poder público e população, mobilizando e integrando ações de interesse coletivo para a construção de uma verdadeira cidadania.

- Contribuir para a diminuição dos índices de violência e de exclusão social na região, estabelecendo parcerias, de modo a mobilizar recursos que envolvam todas as esferas de governo: federal, estadual e municipal, e a iniciativa privada.

- Pesquisar, desenvolver e implantar ações educacionais, culturais, esportivas, de capacitação profissional, geração de renda e de incentivo à economia e ao desenvolvimento local, que diminuam efetivamente os níveis de exclusão social da região" (CADS, Subprefeitura M’Boi Mirim, 2007). 
Para viabilizar as proposta, definiu-se como estratégia de intervenção a mobilização e o incentivo à participação de atores sociais como, por exemplo: moradores, equipamentos públicos (de Assistência Social, Saúde, Educação, Segurança Pública, entre outros), organizações não-governamentais, associações comunitárias, iniciativa privada, igrejas, grupos culturais e agremiações esportivas para a implantação de propostas para o desenvolvimento local e superação de problemas, além da produção de ações e eventos que contribuam para o enriquecimento cultural e educacional local.

\section{- O plano de ação}

Para o desenvolvimento da proposta, a Subprefeitura M'Boi Mirim elegeu dez Pólos de Intervenção, cujos critérios para a escolha levaram em consideração os locais classificados como áreas de risco de enchentes e desabamentos, os dados sobre rendimento dos chefes de família (até três salários mínimos) e o mapa de vulnerabilidade social do município.

A delimitação desses pólos foi construída com base no processo de territorialização desenvolvido pelas UBS das regiões. Foram identificadas e definidas as áreas. Esses territórios foram denominados de Pólos de Desenvolvimento e a proposta consistiu em elaborar um projeto específico, por uma organização proponente, preferencialmente com atuação na área de abrangência dos Pólos, a partir de uma pesquisa participativa que envolve os vários atores sociais da área dos Pólos. A direção geral do projeto é de responsabilidade do Subprefeito de M'Boi Mirim, por meio da Coordenadoria de Assistência e Desenvolvimento Social da Subprefeitura.

Em janeiro de 2006 foi implantada a primeira edição do Projeto Pólos, que foi interrompida em julho daquele ano, devido ao congelamento de verbas no orçamento municipal. Em novembro de 2007, foram retomadas as atividades dos Pólos, com a assinatura do convênio, para iniciar os trabalhos no Pólo Cidade IpavaAracati. A proposta era dar início ao funcionamento, até março de 2008, do Pólo do 
Jardim Ibirapuera. No entanto foram desenvolvidas ações apenas no Pólo Cidade Ipava-Aracati.

\section{- Diretrizes e objetivos}

As ações dos projetos visam contribuir de maneira efetiva para a diminuição da violência e para o incentivo ao desenvolvimento local das regiões atendidas. Tem como estratégia a participação comunitária cada vez mais ampla. Visam pesquisar, desenvolver e implantar propostas alternativas de geração de trabalho e renda para grupos de jovens e familiares além de fomentar o desenvolvimento cultural, esportivo e educacional local.

Segundo o entrevistado da subprefeitura, a proposta dos Pólos complementa as ações que são inerentes às subprefeituras e não são suficientes para reverter a gravidade do quadro apresentado nas periferias da cidade. É preciso, na sua opinião dele, que as pessoas participem, discutindo os problemas da realidade cotidiana:

A subprefeitura sempre foi vista como o instrumento de zeladoria do bairro. São poucas as subprefeituras que desenvolvem outro tipo de trabalho a não ser o de zeladoria e a implementação de pequenas obras de infra-estrutura urbana e assim por diante. Aqui, especificamente com a subprefeitura de M'Boi, nós sempre tivemos a preocupação de focar o trabalho, então qual foi o foco do nosso trabalho? Até pelas características desse nosso território, nós temos aí um passado de uma imagem muito violenta, de criminalidade, de altos índices de criminalidade, de homicídios então nós fizemos um levantamento (...) das áreas de maior vulnerabilidade na região e começamos a trabalhar com infra-estrutura urbana, quer dizer, dotar essas regiões de melhores condições de acesso, de áreas de lazer, e acabamos percebendo que isso, por si só não era suficiente pra reverter um quadro grave como é a periferia de São Paulo e foi aí que surgiu (...) os pólos de desenvolvimento que tem como finalidade a complementação das ações da prefeitura, da subprefeitura de $M$ 'Boi Mirim. Então nós tratamos, além da infra-estrutura urbana, que é nossa atribuição primeira nossa, pavimentação, acessibilidade, canalização de córregos, e essas coisas todos que são importantes na vida das pessoas, que inclusive traz a imagem, interessante que essa imagem de progresso na periferia, dentro de um pólo de desenvolvimento que trabalha com arte, com cultura, com educação pra poder efetivamente, fazer um trabalho de inclusão, de participação trazendo as pessoas a discutir um pouco o cotidiano, as dificuldades e uma reflexão sobre o meio em que as pessoas vivem e eu acho que isso é o fundamental, isso é o legado que nós gostaríamos de deixar.

\section{- Ações do grupo intersetorial}

Além dos Pólos, outras ações foram propostas pelo grupo intersetorial da subprefeitura para o enfrentamento da violência. $O$ grupo se reúne uma vez por mês e é composto pela Polícia Militar, Polícia Civil, Promotoria Pública, coordenadorias das subprefeitura, Sabesp - Companhia de Saneamento Básico do Estado de São 
Paulo e segmentos da sociedade, para definir ações em conjunto, como, por exemplo, o fechamento dos bares entre o horário das 10 e 11 horas na região. Foi uma ação polêmica, considerada necessária, e a subprefeitura tem a atribuição de fiscalizar o cumprimento da determinação. Os resultados foram avaliados positivamente, e a ação tem o apoio da comunidade, conforme relato:

Foi discutido através de um levantamento da Polícia Militar, que os homicídios aconteciam num raio de $100 \mathrm{~m}$ de cada bar, 91\% de homicídios num raio de $100 \mathrm{~m}$ de cada bar, no período das 11 da noite às 6 da manhã. E aí nós começamos a fazer um trabalho de fechamento dos bares nesse horário, então os bares aqui fecham entre 10 e 11 horas. Como não existe uma legislação específica pra isso, mas por outro lado, grande parte aqui da região o comércio não tem alvará de funcionamento, porque o crescimento urbano foi desordenado, (...) totalmente irregulares, e também ficou estabelecido que, se nós saíssemos fechando tudo nós criaríamos um problema social grave, porque grande parte do comércio aqui na periferia são comércio de subsistência, então nós fizemos um trabalho de conscientização: nós vamos lá, falamos com o dono do bar, do comércio, explicamos a finalidade e pedimos que eles façam uma adesão pra que o bar fosse fechado às 10 horas. Num primeiro momento, (...) nós detectamos uma queda nos índices de criminalidade, esse é um ponto. Aonde essa adesão não é feita, aí a prefeitura faz uma ação fiscalizatória mais enérgica e que inclusive tem o apoio muito positivo da própria comunidade nesse sentido. Esse é um trabalho que é polêmico? É polêmico, mas é necessário.

\section{- Projetos para os jovens na região}

Segundo o entrevistado, o trabalho principal da subprefeitura em relação aos jovens é o desenvolvido pelo Pólo, que é uma iniciativa exclusiva da subprefeitura, com base em um programa que nasceu em Itapecerica da Serra, nos Barracões Populares da Cidadania. Há ainda uma parceria com o Sesc - Serviço Social do Comércio, para atividades de lazer e cultura. Cita também que foi transformado um espaço de aproximadamente 1.500 metros quadrados, onde existia um sacolão, em Sacolão das Artes. Pretende-se criar uma Casa de Cultura (Casa Brasil) em parceria com a Prefeitura de São Paulo e com o governo federal na região. Está em andamento também a transformação de um abrigo no Jardim Imbé, em uma casa de cultura no Jardim Ângela.

$\mathrm{Na}$ região, segundo o entrevistado, há ainda um trabalho social bem organizado, destinado aos jovens, desenvolvido pelas entidades sociais, em sua maioria subsidiadas pelo poder público. 
O principal é o pólo porque esse é um trabalho exclusivo da subprefeitura (...) nós temos muito trabalho aqui com organização social com jovens e adolescentes. $O$ que as organizações não falam, quer dizer, elas são muito importantes como instrumentos, são todas subsidiadas pelo poder público, e quando você vai discutir com uma entidade qual a repercussão do trabalho, elas, de forma muito acertada, elas contam o trabalho que estão realizando (...), a inclusão, (...), mas poucos falam claramente que esse trabalho é subsidiado pelo poder público. São raríssimas as organizações sociais que não são subsidiadas pelo poder público, e isso é um ponto positivo. Então, de certa forma, a prefeitura de São Paulo participa não direta, mas indiretamente de todas as ações. O Pólo não, o Pólo é uma iniciativa exclusiva da prefeitura, da subprefeitura, não tem em outras subprefeituras. Isso foi baseado num programa que nasceu em Itapecerica, que é nos Barracões Populares da Cidadania, e que tem como finalidade criar atrativos pros jovens, mas não só pros jovens, mas pro adolescente, pra terceira idade, oficinas, teatros, pintura, leitura (...) você tem o esporte, utilizando a estrutura existente, a discussão de problemas locais, cinema, a maioria das pessoa aqui nunca foram no cinema, excursões pra pontos turísticos de São Paulo, conhecer a cidade de São Paulo, conhecer aonde mora, ter um referenciamento geográfico da importância do território que ele mora, no todo porque na maior parte o nosso território é área de proteção de mananciais, atividades em finais de semana. Agora teve, há poucos dias, uma parceria com o SESC que além de lazer, teve atividades culturais. Não é especificamente no distrito do Ângela, mas é na divisa do distrito do Ângela com o São Luís, nós pegamos e desativamos um sacolão e transformamos este espaço de mais de 1.500 metros quadrados, no Sacolão das Artes. Tem todas as organizações que trabalham com arte e cultura que se manifestam nesse espaço, inclusive os do Ângela (...) e isso vem dando muito bom resultado, tem um espaço de manifestação, você tem um sarau de poesias, você tem exposição de pinturas, e já nós vamos instituir uma parceria da Prefeitura de São Paulo, da subprefeitura de M'Boi Mirim com o governo federal, uma Casa Brasil, uma casa de cultura. Está em andamento também a transformação de um abrigo no Jardim Imbé, numa casa de cultura no Jd. Ângela (...) ali também é subsidiado e apoiado pela prefeitura de São Paulo, inclusive havia uma referência histórica da casa de cultura pela luta, pela sobrevivência (...).

- Os problemas que afetam a vida dos jovens.

A região, de acordo com o entrevistado, tem problema com transporte, as

pessoas têm medo de sair à noite para participar dos eventos, falta infra-estrutura, espaço de convivência e lazer, pavimentação, além de todas as carências existentes.

Não há recursos para atender todas as necessidades, sendo preciso priorizar as ações.

A população é solidária, há muitos mutirões para ajudar:

(...) a distância, do centro, dos bairros, de mais infra-estrutura, tem problemas de transporte, que a região é muito grande, a referência é Santo Amaro, tem problema de transporte... (...) as atividades acontece à noite, as pessoas têm muita preocupação de sair, voltar tarde, é a falta ainda, carência ainda, de espaços de convivência na região onde moram, uma das dificuldades também é que ainda, dentre todas as carências que nós temos, que são enormes, são muitas, da questão do lazer (...) do espaço de convivência, ainda não chegou como prioridade primeira (...), muitas ruas não têm pavimentação, tem que fazer...então você não tem recursos pra fazer tudo ao mesmo tempo, então tem que subir degrau por degrau, chegar no topo. O que facilita: a disponibilidade da comunidade, a participação, tem que fazer as coisas em conjunto...por exemplo, nós tivemos aqui 12 mutirões simultâneos, "olha, não dá pra fazer o campo de futebol da Vila Gilda, mas eu tenho o material pra fazer o vestiário (...) então falta colocar terraplanagem, instalar trave, a comunidade ajuda e a gente faz o vestiário. (...) olha, tem que fazer um acesso porque tem 
problema de chegar o transporte escolar na Nova Cidade...não tem como entrar porque é uma área irregular. Vamos fazer um mutirão e vamos concretar a rua, a gente vai lá, concreta a rua pra passar o transporte escolar...acho que é um potencial enorme de poder trabalhar.".

\title{
- Participação
}

Segundo o entrevistado, a comunidade é muito solidária e participativa, com projetos para a melhoria do território. A disponibilidade e a solidariedade são os diferenciais para transformação, e a Igreja Católica tem um papel muito importante nesse sentido:

\begin{abstract}
Ah...é isso, porque eles participam pra poder mudar aquela região, mas isso em grupo, sozinhos não conseguem então quantas vezes a gente vai num bairro, num final de semana, tem um monte de gente enchendo a laje do vizinho. Então a pessoa tem que morar e não tem recurso pra pagar, então se reúnem lá e vamos encher laje, fazer mutirão. Então eu acho que esse é o grande ponto de transformação: é a disponibilidade e a solidariedade das pessoas. E olha, a igreja daqui, sobretudo a Católica, tem um papel muito importante sobre esse processo..
\end{abstract}

Diferentemente de outras regiões, apesar do medo da criminalidade, a população se organiza e participa para mudar o ambiente:

Porque as pessoas (...) têm medo de violência, da criminalidade, enfim...só que elas não se enclausuram num canto, elas saem com um projeto de melhoria do território pra poder mudar esse fato, o que é diferente de outros lugares de São Paulo (...) as pessoas ficam presas dentro de casa e não se relacionam. Aqui não, aqui as coisas têm sido de forma contrária..

\section{- Opinião sobre a juventude: a participação dos jovens}

O entrevistado entende que os jovens não acreditam na política devido à carência e à falta de oportunidades vivenciadas, ora considera os jovens otimista, ora descrentes, atribuindo essa descrença ao contexto social. Considera a juventude alienada e que esta não participa dos problemas da cidade:

Eu acho que (silêncio) a juventude da periferia, ela, apesar de tudo, apesar de não acreditar na política, nos políticos, descrente de tudo, pela falta de oportunidade, pela falta de emprego, de educação de qualidade, ela é uma juventude otimista e por causa desse otimismo criam ações que são exemplares (...) toda quarta-feira à noite, tem um Sarau de Operisca, num bar (..) Operisca. Eles fazem lá. Já saiu no Estado de São Paulo, no Jornal da Tarde, é super conhecido, promove os encontros, é um conjunto saudável, eu não acho que eles acabam delirando com o pouco que eles têm, eles são otimistas. Agora, muito descrentes, muito céticos, qualquer tipo de intervenção eles fazem bloqueio e alienadas no sentido de participação da vivência da cidade (...) eles estão em outra. 
Para o entrevistado, os jovens vivem no mundo do consumo, sem acesso aos objetos de desejo e em uma cidade virtual, pensa que só investindo em ações de cultura é que se pode mudar a realidade, evitando que eles sigam o caminho da violência e da delinqüência:

Então a referência deles hoje não é a cidade que nós vivemos, mas é um shopping center, um shopping center ele é uma edificação, é uma tradução ruim do que é a cidade: você tem as lojas, você tem as vielas, você tem alamedas, você tem um café, você tem o cinema, é uma tradução mal e porca da cidade (...) e os jovens daqui tem um shopping perto, não tem poder aquisitivo para ir no Morumbi e além disso é a cidade virtual, a cidade da telinha do computador, da televisão, da novela, do consumo desenfreado, e eles têm direito de viver também como qualquer segmento da sociedade. Só que eu também acho que estejam muito desinibidos, nós estamos vivendo numa sociedade de consumo e todos querem tênis Nike, mas não conseguem comprar. Todos querem ter um carro, uma moto, esse é o perigo porque é isso que pode levar o jovem à delinqüência e acho que é só a cultura, tô convencido, só a cultura, mas são heróis da periferia mesmo..

\section{- Principais problemas dos jovens}

Para o entrevistado, os principais problemas dos jovens são: a falta de oportunidades e de perspectivas, gerada por uma educação deficiente e pela exclusão social. A falta de perspectivas, na opinião dele é um dos fatores que gera o aumento da violência:

Eu acho que é a falta de oportunidade. Outro: é a falta de perspectiva (...) sempre tem um projeto diferente (...) um gosta de boxe, gosta de computador, quer mexer com isso, e no final acaba não sendo nada disso. Mas eu acho que é a falta de oportunidade e essa falta de oportunidade ela se dá basicamente por uma educação deficiente, a exclusão social, a distância dos centros mais desenvolvidos, a mudança do perfil do trabalho em São Paulo, ninguém quer alguém menor qualificado, e a falta de uma política integradora, são (...) condicionantes que geram essa exclusão e essa falta de perspectiva que também é um dos fatores do aumento da violência, que daí eles vão viver na sociedade paralela, da marginalidade (...) porque eles vivem numa cidade marginal, que não é fruto do planejamento, que não é fruto da intervenção do Estado, que não é fruto da imagem da cidade, a cidade oculta, a cidade marginal (...) mas é uma cidade que não existe. A cidade, a sociedade, é a avenida paulista, é a ponte Estaiada que tem ali, que é o novo cartão postal de São Paulo, e a pobreza hoje, da região metropolitana de São Paulo, hoje, tem $23 \%$ do PIB nacional, se produz na região metropolitana de São Paulo, que tem $12 \%$ da frota de veículos de todo o país, mais de 6 milhões de veículos, que é uma cidade mundial por causa dos fluxos do capital financeiro; por outro lado é a imagem mais aterradora da tragédia nacional, que é a pobreza concentrada. Então os jovens da periferia são jovens fruto desse processo. É triste, né?. 


\section{- Potencialidades da região}

Para o entrevistado, a região passa por um processo de transformação, foi inaugurado o Hospital de M'Boi Mirim, que gerou empregos para os moradores:

Olha, eu acho que nós estamos aqui sofrendo um processo de transformação importante. Por exemplo, vamos pegar aqui o hospital do M'Boi, que foi inaugurado agora, semana passada. O hospital do M'Boi, segundo informações do Einstein, contratou 1.500 pessoas, $40 \%$ é daqui, grande parte jovens, segundo informações que me passaram. É um fator de transformação importante.

A construção dos CEUs, de bibliotecas, da Escola Técnica e a proposta de uma nova linha de ônibus, para facilitar o acesso a esses equipamentos, segundo o entrevistado mudarão as características da região. Outro potencial da região a ser explorado são os 11 clubes náuticos que estão desativados:

Agora, tem um potencial a região, que está inexplorado que falta aí, eu acho que, um pouco de disponibilidade dos proprietários para que isso possa se efetivar, que é a utilização dos clubes náuticos.

Nós temos mais 11 clubes próximos à represa que viveram um período de prosperidade da região e francamente a nossa região, o nosso território, ele não é um lugar onde você veja a prosperidade com muita facilidade: a ocupação, a pobreza, a violência acabou fazendo com que esses clubes perdessem muitos sócios. Hoje quando a classe média compra apartamento ela leva o clube junto: você tem a piscina, tem a quadra (...), e os clubes náuticos aqui tem uma infra-estrutura, a maioria são belíssimos. (...) acho que nós poderíamos utilizar esses espaços, é um potencial enorme, nenhuma outra subprefeitura tem, que a comunidade pudesse participar (...) teria que buscar uma integração (...) pra que isso possa ser aberto à comunidade. Aí nós teríamos dois CEUs, as bibliotecas que estão sendo feitas, a escola técnica e 11 clubes. Nós passaríamos de um território que tem um dos menores números de espaços de convivência como a subprefeitura que talvez tenha o maior número de espaços de convivência.

No entanto, apesar das propostas, existem dificuldades, sendo necessário encontrar uma solução:

Agora, por que é difícil isso? Porque o clube, você tem... alguns tem problemas financeiros, outros clubes você não tem nem diretoria mais, você tem clube que tem dono, só ele fica tomando conta, ele vira o dono daquele espaço, mas você tem um potencial que pode ser tratado, tem que achar uma solução pra isso e seria um fator de mudança importante, tanto quanto os investimentos que estão sendo feitos. 
Outro potencial é a energia das pessoas, e há experiências que estão dando certo:

E o potencial nosso aqui (...) além dessas (...) que tá muito próximo ao meio ambiente é você utilizar toda essa energia que as pessoas têm na periferia pra fazer mutirão, pra fazer um processo de transformação, de conscientização. Sabe uma coisa que tá dando muito certo aqui? A prefeitura vai investir quase 1 bilhão de reais em reurbanização através da SEHAB, Secretaria Municipal de Habitação, então vai pegar lá: Chácara Bandeirantes, Bananal, Vila do Sol, Nova Cidade, tirar a favela da Muriçoca, isso é ótimo mas se você não tiver um congelamento da ocupação (...) não vão ter o retorno esperado, de melhoria daquele território. Então a gente chega, marca reunião e fala "olha, o negócio é o seguinte: nós temos que melhorar aqui a vida das pessoas”, colocar esgoto, água, luz, praça, quadra esportiva, tudo o que isso vem junto, mas se a gente quiser um projeto pra 5 mil famílias, quando chegar aqui tem $10 \mathrm{mil}$, 5 mil não vão ser beneficiadas. Então nós temos que congelar: quem está, fica, quem não está, não pode vir pra cá. E isso é aceito de pronto, as pessoas têm nos ajudado a congelar esse território pra que os investimentos públicos possam dar o resultado.

- Resultados das ações para a qualidade de vida da população e enfrentamento da violência

Conforme o entrevistado existe um trabalho integrado em desenvolvimento há anos no Jardim Ângela, visando à melhoria das condições de vida e ao enfrentamento da violência. São várias ações desenvolvidas com a Polícia Comunitária, as ONGS, os jovens e adolescentes, a terceira idade e o fechamento de bares. Além disso, a construção de dois CEUs, sendo um no Jardim Vera Cruz e outro próximo do Jardim Nakamura, bem como a proposta de uma Escola técnica na região, tem contribuído para propiciar perspectivas de trabalho e de vida para os moradores.

O padre Jaime tem uma posição que eu concordo com ele plenamente: é a somatória de pequenas ações que dá resultado. Quer dizer, é a Polícia Comunitária, são as ONGs que trabalham na periferia, é o trabalho com jovens, adolescentes, o trabalho com a terceira idade, é o fechamento dos bares, é a construção das áreas de lazer, aqui estão construindo dois CEUs que acho que são instrumentos importantes em áreas periféricas com alto grau de violência e criminalidade, uma fica no Jd. Vera Cruz, e outra próxima ao Jd. Nakamura, são dois CEUs no distrito do Ângela que até então o único CEU aqui, ele ficava no distrito do Jd. São Luiz, ali no Jd.Casablanca. O outro ponto que agora vai sair é uma Escola Técnica ao lado do CEU Guarapiranga, perto do Nakamura, acredito que vai ser importante, sobretudo pra juventude que sai da escola pública sem perspectiva de trabalho, sem perspectiva de vida. 
O trabalho nos Pólos de Desenvolvimento, segundo o entrevistado, tem contribuído para diferenciar violência e criminalidade. Na opinião dele, esse trabalho pretende conscientizar os moradores sobre as dificuldades enfrentadas no cotidiano e a carência de políticas públicas, o que é considerado como violências.

uma coisa que me chama muito a atenção aqui é que as pessoas confundem violência e criminalidade. A violência do cotidiano e as dificuldades da vida, pela implementação de um consumo desenfreado, da falta de atendimento, muitas vezes (...), isso faz parte da violência contra o cidadão, mas as pessoas não entendem e acham que a violência é a criminalidade e não é só isso. Então esses Pólos que foram criados aqui, de desenvolvimento, e esse trabalho igual também tenta conscientizar as pessoas que a violência, nós enfrentamos todos os dias: com a falta de infra-estrutura urbana, com a falta de áreas de lazer, as carências das políticas públicas de atendimento ao cidadão, isso faz parte da violência do dia a dia, né?

A ação de fechamentos dos bares não tinha como foco a violência doméstica; no entanto, o entrevistado constata que houve repercussão e diminuição dessa modalidade.

uma coisa que também me chama a atenção, com o fechamento dos bares, e aí eu não tenho dados (...) é o reflexo na diminuição da violência doméstica, além da criminalidade, da morte, do homicídio. E, convenhamos, como eu disse, esse não era o foco, o foco era diminuir o número de homicídios, os delitos, talvez sejam mais graves, e que acabou repercutindo na diminuição da violência doméstica, então a subprefeitura tem atuado nessa idéia.

\section{- Propostas para a região}

As propostas da subprefeitura para a região referem-se a realizar parceria com a iniciativa privada a fim de gerar emprego e renda, melhorar o transporte, propiciar acessibilidade para bairros da região, mudar o zoneamento da região, que é industrial, pois avalia-se que as indústrias não irão para a região, uma vez que o futuro das grandes metrópoles será na área de serviços e comércio. Com a mudança na lei de proteção aos mananciais, acredita-se que poderá haver um desenvolvimento local e a região poderá se tornar mais atrativa para os investidores, enquanto isso a subprefeitura tem a função de melhorar a infra-estrutura para atrair as pessoas. 
A gente tem que ter a parceria da iniciativa privada, não adianta a prefeitura chegar $e$ "oh não, nós vamos trazer emprego, e renda”, porque é isso que precisa, a pessoa tem que trabalhar, tem que ter renda, tem que ter educação e assim por diante. (...) quando você olha (...) você vem pela Guido Caloi, e do lado de cá da Guido Caloi você tem um tipo de desenvolvimento e do lado de lá tem outro tipo, você tem o Transamérica, você tem o Santander (...) e aqui você não tem nada. O zoneamento aqui é industrial. Se você pega a Guido Caloi, uma via importante de acesso, só pode construir indústria e vocês estão sabendo que a indústria não vem mais pra São Paulo, a cidade vai ser uma cidade terciária, de serviços, comércio, esse é o futuro das grandes metrópoles. É difícil tomar como as cidades eram no século dezenove, que era um espaço de encontro, de cultura, de lazer (...). Uma briga que nós estamos, no bom sentido, solicitando, é que mude o zoneamento da Guido Caloi. Eu acho que se mudar o zoneamento da Guido Caloi, naturalmente a empresa privada virá). Então, essa...eu tô falando da Guido Caloi, uma...um outro ponto importante que as pessoas ainda não perceberam, é que foi mudada a lei de proteção dos mananciais. Com o uso e ocupação do solo, a maior parte é aqui na subprefeitura de M Boi Mirim, a gente tá em área de proteção dos mananciais, e a lei foi mudada faz 1 ano (...) então a gente tem um potencial que não tinha, e esse foi um ponto fundamental pra gente começar a ter uma política de desenvolvimento local. Porque hoje com os investimentos de qualidade você chega até o Terminal Ângela de ônibus, dali pra lá, dali pro sul, pra Itapecerica, você não tem mais investimento de qualidade. E agora poderá ter, porque a lei permite, então acho que você começa a transformar esse território esquecido num território atrativo pra investimento de qualidade, que gera emprego e renda, por exemplo: são vários mercados querendo vir pra cá. Tem vários mercados (...) que tá aprovando projetos, plantas, e acho que isso é um ponto importante. O que nos cabe? É continuar fazendo investimento pra que esses investimentos da iniciativa privada também tenham infra-estrutura adequada pra que as pessoas possam chegar. Acho que tem que fazer a extensão da Carlos Caldeira, que tá lá no metrô Capão Redondo, (...) um hospital, que tem um projeto pronto já (...) tem que melhorar a acessibilidade. 
DISCUSSÃO 


\section{DISCUSSÃO}

\section{A COMPARAÇÃO ENTRE OS DISTRITOS DO JARDIM ÂNGELA E DO GRAJAÚ}

O estudo permitiu verificar que o distrito do Jardim Ângela e o Grajaú, localizados na região sul do município de São Paulo, e incorporados desde agosto de 2002 às subprefeituras de M'Boi Mirim e de Capela do Socorro, respectivamente, têm em comum vários aspectos.

Ambos os distritos estão em áreas de proteção ambiental. O processo de ocupação nos dois distritos administrativos teve início a partir da década de 1960, associado à industrialização da região de Santo Amaro e ao desmembramento de antigos sítios e chácaras de ambas regiões, além da criação de bairros e vilas caracterizados por loteamentos irregulares, desprovidos de infra-estrutura, o que permanece, em muitas áreas, até os dias de hoje.

Os dois distritos apresentam crescimento demográfico elevado, com predominância da população de baixa renda, migrante de outras regiões do país. Os perfis populacionais, conforme censo demográfico 2000, são semelhantes para os dois distritos, revelando uma grande proporção de população jovem e alta taxa de natalidade.

No que se refere à distribuição percentual dos domicílios segundo a renda mensal domiciliar em faixas de salários mínimos no Jardim Ângela e no Grajaú, os domicílios de até três e entre três e cinco salários mínimos representam, respectivamente, 60,3\% e 58,8 \% do total de domicílios do Jardim Ângela e Grajaú contra $37,7 \%$ do total para o município de São Paulo.

Comparando o percentual da população classificada, segundo os critérios de agrupamento da condição de vulnerabilidade, considerando as dimensões socioeconômica e a demográfica, cujas variáveis indicam resumidamente: a condição de educação dos responsáveis pelos domicílios, a renda, a idade, a estrutura familiar e as condições de habitação, verifica-se que os grupos de alta e altíssima privação e a presença de jovens reunidos correspondem, nos distritos de Grajaú e Jardim Ângela, a $35,57 \%$ e $37,59 \%$, respectivamente, e $11,15 \%$ para o total do município, 
associando a esse grupo etário uma alta condição de vulnerabilidade social nas áreas de estudo.

Quanto à taxa de mortalidade por agressões/homicídios, caracterizada pelos eventos descritos pela Classificação Internacional de Doença - CID 10 nos itens de X85 a Y09, esta apresentou o menor valor em 2006 desde 1996 e tem refletido uma tendência persistente de queda nos últimos anos no município de São Paulo.

Quanto aos distritos do Jardim Ângela e Grajaú, essa tendência se mostra igualmente presente apontando uma redução da violência representada pelas mortes decorrentes de agressões/homicídios, sendo mais acentuada a partir de 2003, para ambas as áreas distritais. Os dados secundários possibilitaram constatar que o número de óbitos relativos às populações jovens e na faixa de 15 a 19 anos de idade, no município de São Paulo e nos distritos de Jardim Ângela e Grajaú, também se mantém em queda.

$\mathrm{Na}$ análise da rede de proteção aos jovens nos distritos, constatou-se que os projetos, programas e ações desenvolvidas nas regiões de estudo, em última instância, buscam tirar os jovens das ruas por meio de atividades diversas que preencham o tempo ocioso. As intervenções estão voltadas principalmente para a redução do risco de violência, referido por um terço das entidades, seguidas pelo foco voltado para a educação, cultura, desenvolvimento socioeducativo, que muitas vezes prevê programas educacionais e culturais, a prática de esportes e o lazer, principalmente.

A análise da rede de proteção social, por meio da Análise de Correspondência - AC, que relacionou as entidades que indicaram ligações e o tipo de programa relativo às organizações citadas com o objetivo de identificar diferenças nos dois territórios analisados no estudo, mostrou que, no distrito do Grajaú, as escolas têm um papel relevante, atuando com diversos programas e ações, o que parece ser natural, uma vez que esse ator é o que está mais próximo dos jovens e adolescentes. Entretanto, há os demais atores, como as associações, de bairro, comunitárias e assistenciais, que têm vocação para a prática assistencial, principalmente relativa à distribuição de leite e à guarda de crianças (creches e berçários). Outros atores atuam no território, cumprindo papéis semelhantes, sem, estabelecer uma caracterização mais bem definida. 
No Jardim Ângela, o quadro se apresenta de forma um pouco diferenciada, cabendo um papel relevante para as escolas, como no Grajaú, e para as entidades de saúde na administração de programas. As associações acrescentam, ao lado da prática assistencial, o importante papel da alfabetização.

Para o exame do relacionamento entre as entidades, adotou-se o conceito de centralidade introduzido por BAVELAS (1948), aplicada ao conceito de comunicação FREEMAN (1978), considerando, basicamente, a proeminência das associações na disseminação de seus programas, projetos e ações voltadas para os jovens, ou seja, a importância delas no contexto do enfrentamento da violência entre jovens e adolescentes, entre outros objetivos.

Por essa perspectiva, buscou-se identificar junto às associações locais o grau de centralidade que se apresentava no relacionamento entre outras associações existentes nos territórios, e como se estabelecia o relacionamento entre todos os atores e se é possível reconhecer grupos ou claques em que cada entidade está mais direta e fortemente ligada.

No distrito do Grajaú, pode-se identificar a centralidade de um grupo que está centrado no Circo Escola e Projeto Anchieta, um outro centrado no Conselho Tutelar, Casa da Cultura e Projeto Guri, além de um terceiro, com menor grau de concentração.Verificaram-se ainda outros grupos dispersos e sem articulação entre si, representado ilhas de relacionamento. Esses grupos estão articulados no território, podendo-se imaginar a possibilidade de integração das diversas ações empreendidas de forma mais sinérgica.

$\mathrm{Na}$ análise da rede social do Jardim Ângela, quanto à centralidade dos projetos, destacaram-se a Casa da Cultura, o Arco Beneficente, o Clube da Turma, Cardeal Rossi e os Santos Mártires, como entidades protagonistas da ação na região.

Quanto à formação de grupos ou claques, podem-se distinguir claramente pelo menos três grupos: um grupo que se articula principalmente pela inspiração da Igreja Católica, que atua no território do Jardim Ângela de forma intensa, principalmente pela Sociedade Santos Mártires, como promotora e articuladora de programas; um grupo centrado na Casa da Cultura do M'Boi Mirim; e um grupo centrado no Clube da Turma e nas Unidades Básicas de Saúde - UBS. Observaram- 
se também entidades que não constituem um grupo articulado, correspondendo à ilhas isoladas.

Diferentemente da região do Grajaú, os grupos se relacionam por meio das associações existentes na região ou então das UBS, com Programa Saúde da Família, o que pode indicar maior capacidade de articulação de planos com ganho de sinergia na ação.

Nos dois distritos de estudo, verifica-se a preocupação com as altas taxas de homicídios e violência, pelo poder público local -no caso as subprefeituras. Ambas subprefeituras têm projetos e ações para o enfrentamento da violência e melhoria das condições de vida da população.

No que se refere às políticas públicas, no Grajaú está em desenvolvimento desde 2006 o Projeto São Paulo em Paz - projeto piloto municipal de segurança pública para a cidade em parceria entre a Secretaria Especial de Participação e Parcerias da Prefeitura da Cidade de São Paulo e o Instituto Sou da Paz.

O Plano Local de Prevenção e Promoção da Convivência do Grajaú por meio da participação comunitária e articulação intersetorial propõe a complementação e fortalecimento de ações já desenvolvidas no Distrito e a implantação de novas ações.

Na primeira etapa do Plano foi elaborado o diagnóstico no distrito, contendo informações quantitativas e qualitativas sobre crimes, violências, programa de prevenção do poder público e da sociedade civil e percepções sobre o tema, em que, segundo a ONG articuladora, houve maior participação da população, o que não ocorreu nas fases posteriores. Na segunda etapa foi elaborado o Plano contendo propostas prioritárias, identificadas pelos atores locais para prevenir a violência e promover a convivência pacífica no distrito. Na definição dos projetos, foi dada prioridade para ações voltadas aos jovens da região, visando ao enfretamento da violência.

Pressupõe-se que para o desenvolvimento e consolidação do plano é preciso realizar a articulação intersetorial e a participação social. Entretanto, verifica-se a ausência da participação da maioria das entidades, bem como a ausência dos jovens que integram a rede cultural, do Pró-Jovem e de outras entidades da região.

Existem dificuldades de adesão ao Programa pelas entidades locais, para realizar parcerias e diálogo com a subprefeitura, além da diversidade de ações 
pontuais. O Instituto Sou da Paz atua na articulação e mediação dos conflitos entre os diferentes setores públicos, entidades e comunidade, com a colaboração de outras ONGs que atuam na região.

Em função desses dados e considerando a hipótese inicial do estudo, verificase que esta se confirmou parcialmente. A hipótese inicial era a de que a existência de políticas públicas e de ações coletivas integradas com a participação dos jovens, no distrito administrativo do Jardim Ângela do município de São Paulo, tinha contribuído para reduzir os coeficientes de mortalidade por homicídios nessa mesma população no referido distrito. O distrito do Grajaú, com características semelhantes em termos de vulnerabilidade social ao do Jardim Ângela, não tem alcançado os mesmos resultados em relação à redução da mortalidade por homicídios na população jovem, em função da desarticulação e fragmentação das políticas públicas e das ações coletivas locais e da falta de protagonismo dos jovens. Esta hipótese se confirmou parcialmente, uma vez que a violência é um fenômeno complexo e multicausal e, no decorrer do estudo, observou-se que nos dois distritos administrativos ocorreu uma tendência de queda nas taxas de mortalidade por agressões/homicídios, mais acentuada no Jardim Ângela, acompanhando a tendência persistente de queda nos últimos anos no município de São Paulo.

No Jardim Ângela, há um trabalho integrado em desenvolvimento, liderado pela Igreja Católica, da Sociedade Santos Mártires, para a melhoria das condições de vida e enfrentamento da violência. Em 02 de novembro de 1996, foi realizada a primeira Caminhada pela Paz na região do Jardim Ângela. A partir da Caminhada pela Paz criou-se o Fórum em Defesa da Vida pela Superação Violência, que integra o poder público e a sociedade civil para desenvolvimento de projetos e ações na região e tem ainda o papel de articulador da rede interna e externa.

Verificam-se ainda políticas públicas, como a criação da polícia comunitária, ações de fechamento de bares e implantação de Pólos de Desenvolvimento Local.

Os Pólos visam integrar esforços na região para a implementação de ações culturais, político-econômicas e socioeducacionais que impulsionem o desenvolvimento local e a melhoria da qualidade de vida da população; no entanto, essa proposta enfrenta vários desafios, entre eles integrar as ações para sua concretização. 
Entre as experiências positivas para o enfrentamento da violência no Jardim Ângela, destaca-se a estratégia de realização de ação pública civil contra o poder público, por meio dos Tribunais Populares. Foram realizados dois Tribunais, promovendo ações civis públicas, para que o poder público atendesse as reivindicações da população. O primeiro foi para a área da saúde e segurança em 2002. Em outubro de 2008 foi realizado o segundo Tribunal Público para área de lazer e cultura, mas as reivindicações dessa segunda ação pública não foram atendidas. Esta é uma estratégia intersetorial, muito bem avaliada pelas lideranças na região. Está previsto um terceiro tribunal para cobrar as ações do poder púbico com foco na educação.

Diferentemente do Jardim Ângela, a história de enfrentamento da violência no distrito do Grajaú é mais recente e, entre as ações, destaca-se o Projeto São Paulo em PAZ, com o desenvolvimento do Plano Local de Prevenção e Promoção da Convivência do Grajaú, em parceria com a Prefeitura da Cidade de São Paulo e a ONG Instituto Sou da Paz, que atua como articuladora das ações e mediadora de conflitos na região. Constata-se que um dos principais desafios na região é promover a articulação entre as entidades da sociedade civil, a juventude local, instituições públicas e a subprefeitura, para que ao final do convênio a subprefeitura juntamente com a comunidade local assumam e consolidem o plano na região.

A subprefeitura argumenta que na região há uma grande quantidade de entidades sociais, mas estas não são representativas na comunidade, portanto há que se desenvolver formas diferentes de comunicação, uma delas é o Projeto Capela em Ação, que dividiu a região da subprefeitura em micro-áreas. A subprefeitura percorre as áreas, de acordo com cronograma, procurando envolver a comunidade, os diferentes setores e entidades para discutir os problemas existentes em cada microárea.

Quanto à participação dos jovens, o poder público local avalia que estes participam, quando há espaço e estímulo. Referem que há movimentos de participação em espaços públicos como o EJA - Educação de Jovens e Adultos e os Grêmios nas escolas e que estes não se interessam pelas questões de infra-estrutura da região. A percepção é a de que o interesse da juventude é voltado apenas para lazer e cultura. 
Esta visão, quanto à participação dos jovens, é compartilhada pelo gestor da subprefeitura de M`Boi Mirim, ou seja, os jovens participam de atividades culturais e de lazer e são alienados no que se refere aos problemas da região e da cidade.

As lideranças avaliam que os jovens têm atuado como protagonistas na região para o enfrentamento da violência; no entanto, o estudo mostra que os jovens entrevistados não revelam participar de ações para enfrentamento dos problemas da região. Uma pequena proporção de jovens admitem participar de ações comunitárias

e mutirões. É importante ressaltar que este estudo foi realizado em áreas das equipes de saúde da família, consideradas de maior vulnerabilidade social, o que permitiu identificar a precariedade das condições de vida e de exclusão social.

\section{OS PRINCIPAIS PROBLEMAS EXISTENTES NO DA DO GRAJAÚ E JARDIM ÂNGELA}

Constata-se que a falta de infra-estrutura das regiões, a violência, a ausência de áreas de lazer e cultura, o consumo do álcool e drogas, o tráfico de drogas e os transportes são considerados os principais problemas para os jovens, para os pais dos jovens que não freqüentam a escola, lideranças, profissionais de saúde e educadores nas regiões. Os educadores também mencionaram ausência do poder público. Foram citados ainda a moradia e urbanização precárias, falta de segurança, falta de cuidado com o meio ambiente e a exclusão social pelos profissionais de saúde, que em sua maioria não mora na região.

As principais violências existentes, nas duas regiões para os pais, lideranças, educadores e profissionais de saúde, estão relacionadas ao consumo de álcool e drogas e ao tráfico. Segue-se a violência doméstica, violência sexual e estupros, violência contra criança e os assassinatos. É citado o crime organizado, o que indica, diante dos resultados apresentados, que este está relacionado com o tráfico de drogas. Os assassinatos também podem relacionar-se com o consumo e tráfico de drogas nas regiões.

A violência doméstica foi considerada pelos entrevistados como um grave problema nas duas regiões de estudo. Esta também foi referida pelos jovens. Em face desses resultados, fica evidente a necessidade de formação e atuação de uma rede de 
proteção complementar às famílias, composta de profissionais de saúde de diferentes disciplinas, associações e instituições de serviços públicos e privados.

Foi possível verificar no estudo que os entrevistados consideram que os homicídios e estupros nas regiões têm diminuído; no entanto, a violência doméstica continua sendo um grave problema nas regiões, assim como o consumo de álcool e drogas e a atuação do tráfico.

Segundo os entrevistados, os principais problemas que afetam os jovens são: falta de emprego/trabalho, drogas e álcool, falta de lazer e cultura, falta de oportunidades, educação de baixa qualidade, desestruturação familiar, falta de preparo para o emprego, ausência de sonhos e projetos, falta de ocupação, tráfico, gravidez não planejada, violência e conflitos familiares, falta de equipamentos escolares e creches e a necessidade de um tratamento personalizado e humanizado nas creches e escolas.

A falta de oportunidades e de perspectivas gerada por uma educação deficiente e pela exclusão social também foi considerado um dos fatores que gera o aumento da violência nas regiões. Entretanto, os entrevistados avaliam que a violência tem diminuído nos distritos, embora não tenham indicadores para comprovar.

Os profissionais de educação e saúde ressaltam em seus discursos a desestruturação familiar, o que está de acordo com a imagem muito difundida sobre as famílias das camadas populares, na qual o critério de definição de estruturação e desestruturação é baseado no modelo de família nuclear, constituída por pai, mãe e irmãos. No entanto, os dados mostram que os jovens moram com pai e mãe, e mesmo aqueles que residem só com as mães manifestam desejo de reproduzir o núcleo doméstico e as redes familiares com as quais podem contar. A família é referência de carinho e de apoio, e alguns contemplam os pais em seus projetos desejando dar-lhes uma vida mais confortável. Portanto o que parece definir o grau de relação é a qualidade das relações estabelecidas no núcleo familiar.

Os profissionais da saúde citam como principais problemas de saúde dos jovens das regiões: a gravidez precoce, sendo mais referida no DA do Grajaú; a dependência de álcool e drogas; situações relativas à sexualidade; doenças 
respiratórias, doenças sexualmente transmissíveis - DST,; doenças comuns da idade; violência e problemas de comportamento.

Diante dos problemas existentes nas regiões, o poder público argumenta que não há recursos para atender todas as necessidades, sendo preciso priorizar as ações; no entanto, conta com a colaboração da população, que é solidária e participativa, envolvendo-se em mutirões para ajudar principalmente na comunidade do Jardim Ângela.

O estudo permitiu verificar que as ações intersetoriais ainda são frágeis. Os diferentes setores participam em momentos diferentes, mas a participação é descontinuada em ambas regiões. Existem alguns Fóruns que procuram articular uma rede de proteção às mulheres vítimas de violência e aos adolescente nas regiões, com resultados positivos no Jardim Ângela, porém é necessário investir em uma efetiva participação da população, e em especial dos jovens. A capacitação dos profissionais de saúde na prevenção e assistência às vítimas de violências pode contribuir para fortalecer as iniciativas das redes existentes.

As políticas públicas nas regiões atuam na perspectiva do jovem visto como problema e, por isso, estão voltadas para atividades que visem tirar os jovens da ociosidade, evitando condutas reprováveis na visão dos adultos, como consumo de álcool e drogas e/ou exercício da sexualidade precocemente, e ainda satisfação das necessidades básicas. No entanto, as políticas para a juventude não devem se reduzir à cobertura de satisfações básicas, mas devem estar de acordo com os projetos de vida dos jovens e reconhecê-los como sujeitos de direitos, criando espaços e incentivando a participação para que estes possam de fato se colocar como sujeitos e cidadãos.

Outra questão observada é que os projetos em ambos os distritos estão voltados para as atividades de lazer e cultura, evidenciando que, no contexto de transformações socioculturais, parecem surgir novos lugares no mundo juvenil, quase sempre articulados em torno da cultura (DAYRELL, 2003). Conforme o autor, o mundo da cultura se apresenta mais democrático e possibilita espaços, tempos e experiências que permitam aos jovens se construir como sujeitos; entretanto, no Brasil, a modernização cultural que influencia tanto a vida dos jovens não é acompanhada pela modernização social. Dessa forma, "se a cultura se apresenta 
como um espaço mais aberto é porque outros espaços sociais estão fechados para eles. Portanto não podemos cair numa postura ingênua de supervalorização do mundo da cultura como apanágio para todos os problemas e desafios enfrentados pelos jovens" (DAYRELL, p. 51). Ainda de acordo com o autor, no contexto em que vivem os jovens pobres, qualquer instituição - escola, trabalho ou aquela ligadas a cultura -, por si só, "pouco pode fazer se não estiver acompanhada de uma rede de sustentação mais ampla, com políticas públicas que garantam espaços e tempos para que os jovens possam se colocar como sujeitos e cidadãos e viver plenamente a juventude" (p.51).

\section{PROPOSTAS PARA OS DISTRITOS DO GRAJAÚ E JARDIM ÂNGELA}

Diante da complexidade dos problemas que afetam os jovens, foram apresentadas pelos entrevistados propostas para o enfrentamento da violência e para a qualidade de vida da população, entre elas: oferecer bolsa de estudo e trabalho para afastá-los do caminho do tráfico e da violência. Neste sentido, no Jardim Ângela propõe-se que o hospital de M'Boi Mirim torne-se um Hospital Escola e que haja investimento na formação dos jovens, pois há falta de profissionais de saúde para os equipamentos da região devido a distância. O investimento em transporte também se faz necessário e é um problema na região.

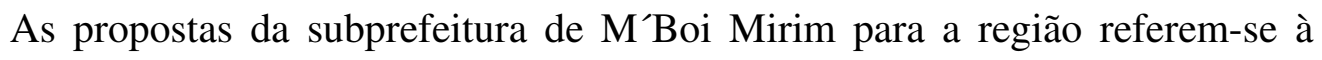
realização de parceria com a iniciativa privada para gerar emprego e renda, melhorar o transporte, propiciar acessibilidade para bairros da região, mudar o zoneamento que é industrial, pois avalia-se que o futuro das grandes metrópoles será na área de serviços e comércio.Com a mudança na lei de proteção aos mananciais, acredita-se que poderá haver um desenvolvimento local, e a região poderá se tornar mais atrativa para os investidores, enquanto isso a subprefeitura deve melhorar a infra-estutura para atrair as pessoas.

No Grajaú há esforços do poder público para criar e desenvolver formas e espaços coletivos de participação, de solidariedade, de aquisição de conhecimentos, melhorar a infra-estrutura da região e aproveitar os recursos naturais existentes para que se possa mudar a realidade e propiciar qualidade de vida à população. 
Ambas as subprefeituras apresentam projetos voltados para o desenvolvimento local, infra-estrutura, reurbanização e revitalização dos espaços públicos, construção e transformação de equipamentos para atividades de cultura, esporte e lazer, destinadas aos jovens para o enfrentamento da violência.

Outras propostas para as duas regiões foram apresentadas pelas lideranças, profissionais de saúde, educadores e pais entrevistados entre elas: promoção da educação, políticas públicas adequadas, presença do poder público, ação local do governo, participação e organização da comunidade, espaços de cultura, esporte e lazer, oferta de empregos, cursos profissionalizantes, mais projetos sociais, investimento em saúde, melhoria da a infra-estrutura das regiões, promoção e fortalecimento das famílias, aumento do policiamento.

\section{A EXPERIÊNCIA SOCIAL DOS JOVENS DO GRAJAÚ E JARDIM ÂNGELA}

Para analisar as percepções dos jovens sobre si, sobre a família, escola e sobre o território onde vivem e as percepções das lideranças, profissionais de saúde, educadores, gestores sobre os jovens, o território e as ações coletivas existentes nos Distritos Administrativos do Grajaú e do Jardim Ângela para o desenvolvimento psicossocial dos jovens e enfrentamento da violência, utilizamos o referencial teórico da experiência social que compreende as três "lógicas da ação": a estratégica, a integração e a subjetivação (DUBET 1994) .

Considerando que cada uma dessas lógicas se desenvolve em uma esfera da vida social - o mercado, as instituições e as representações do indivíduo -, o ponto de partida foi o conhecimento do território onde vivem os jovens para analisar as influências macro-estruturais, identificando as contradições e as transformações sociais que contribuem para a formação dos jovens como sujeitos nas regiões de estudo.

Nesse sentido, o estudo evidenciou contradições importantes ao se analisar o jovem no seu contexto familiar, na escola e nos bairros onde moram, como será discutido a seguir.

Os resultados da pesquisa mostraram que no plano da vida privada a família e sua cadeia de relações ainda é uma forte referência da subjetividade para os jovens que participaram do estudo em ambas as regiões. Os jovens estudantes e não 
estudantes em sua maioria moram e gostam dos seus pais e familiares, mencionando amor, proteção, carinho, apoio e cuidado.

Os jovens consideram o relacionamento como ótimo (47,5\%), entre os jovens estudantes, e bom entre os jovens que não freqüentam mais a escola $(41,6 \%)$. No entanto, evidenciam-se conflitos nos lares, referidos como brigas entre pais e padrasto/ madrasta, irmãos e parentes e ainda que $44,1 \%$ dos jovens estudantes do Grajaú dizem apanhar dos pais e, no Jardim Ângela, 69,2\%. As violências presenciadas e sofridas pelos jovens são as que ocorrem no domicílio. E conforme os educadores, profissionais de saúde e lideranças, a violência doméstica é um grave problema nas regiões de estudo.

No que se refere à escola, os jovens estudantes e os que deixaram de estudar relatam gostar da escola; no entanto, os que deixaram de freqüentá-la admitem perda de estímulo e desmotivação, gravidez não planejada e necessidade de trabalhar. Apesar de não estudarem, os jovens apontam a escola como um recurso importante na região e a valorizam para realizar o projeto de vida: ter um bom emprego. A escola é o assunto mais presente na conversa dos jovens estudantes e não estudantes com os seus familiares, além da família e do trabalho.

Os motivos apresentados pelos jovens que dizem não gostar da escola foram: "bagunça" e indisciplina (18,8\%), prédio e instalações $(10,3 \%)$, não gostam porque não gostam $(9,4 \%)$ e alunos muito violentos $(7,7 \%)$ - referidos pelos jovens de 10 a 14 anos. Os professores também mencionam que, entre os principais problemas nas escolas, estão a indisciplina e o desinteresse dos jovens. Constata-se portanto o conflito existente: por um lado, a necessidade e a importância atribuída a escola pelos jovens e seus pais, para o seu desenvolvimento psicossocial e, do outro, a evasão escolar ainda no ensino fundamental.

Conforme (TOURAINE, 2007, p.81), hoje vive-se "o esgotamento da política social centrada na sociedade, nas suas funções e em sua integração" Hoje devemos nos empenhar "na passagem de uma sociedade fundada sobre ela mesma à produção de si pelos indivíduos, com ajuda de instituições transformadoras"

As escolas atuam dentro da lógica de integração, ensinando valores e normas, ao mesmo tempo conhecimentos. Ela deveria atuar dentro da lógica da subjetividade, 
propiciando à criança não apenas a combinação do pensamento racional e socialização. A escola:

não deve por a criança a serviço da sociedade e não deve tão pouco ser um mero lugar de aprendizado. Deve ser ao contrário, um lugar de formação de atores sociais e, mais profundamente ainda, de sujeitos pessoais.A escola não deve relegar ao domínio da vida privada a religião, a sexualidade, os compromissos políticos,as tradições culturais. Mas é verdade que ela deve, ao mesmo tempo, fazer respeitar a superioridade da cidadania sobre os comunitarismo.".(TOURAINE, 2007, p.153).

Concordamos com ARPINI, (2003, p.169), quando propõe que o papel da escola precisa ser revisto, e que os projetos destinados aos jovens dos grupos populares devem facilitar a permanência na escola, sem que seja necessário fazer uma opção entre esta e o trabalho. Se a necessidade de opção persistir, a escola continuará sendo preterida, por não poder proporcionar aos adolescentes o que se apresenta como necessidade imediata em seu cotidiano. "É preciso pensar em projetos de ensino profissionalizante que contemplem uma perspectiva de crescimento" (ARPINI, 2003, p.170).

Se a batalha cotidiana os priva da perspectiva de um futuro melhor, é preciso instituir ações que possam construir espaços de pertencimento, de autonomia, que permitam a esses jovens construir sua independência, sem privar-lhes do direito de sonhar com um projeto melhor, de uma respectiva de trabalho que não impliquem somente o subemprego. É preciso que a sociedade não mais os submeta à escolha entre a escola e o trabalho. Essa relação escola $\mathrm{x}$ trabalho é violenta e perversa quando veicula a idéia de que eles deliberadamente têm abandonado a escola (ARPINI,2003, p.171)

A escola pretende formar para o futuro, no entanto, esse futuro parece inatingível e sem grandes perspectivas para os jovens pobres. A escola perde o sentido a que se propõe se os jovens não forem motivados a freqüentá-la. A escola, conforme TOURAINE (2007, p.80), que deveria favorecer a igualdade, tende a reforçar a desigualdade, multiplicando os obstáculos no caminho daqueles que provêm de meios subprivilegiados e das minorias culturais.

Segundo TOURAINE (2007), as pesquisas sociológicas mostram que a escola obtém melhores resultados quando os professores se definem por seu papel de 'comunicadores'com os alunos e com os administradores da escola e não apenas por seu papel profissional. Quando os professores se protegem atrás de sua disciplina para enfrentar alunos que rompem a comunicação ou que mostram hostilidades, os resultados são ruins. Este é um dos fatores considerados como êxito escolar. Portanto 
é necessário que a escola questione o seu papel no que se refere particularmente ao fracasso escolar (TOURAINE, 2007, p.156).

Os professores ficam perturbados por ter de transmitir conhecimentos a alunos dentre os quais muitos não têm nenhum interesse nos programas escolares e se aborrecem na escola - onde às vezes ainda se encontram depois de chegar à idade adulta, Mas convém não esquecer que muitas crianças e famílias sabem que seu futuro depende da escola. Os professores , confrontados com grandes dificuldades, adotam freqüentemente atitudes defensivas. 'Estabelecem uma oposição entre os professores que eles são e os educadores', o que na verdade esconde uma falta de interesse ativo pelos alunos que encontram mais dificuldades ( TOURAINE, 2007, p.80).

Segundo TOURAINE (2007), os melhores trabalhos de sociologia na Europa, consagrados a avaliar as ações das políticas sociais nos campos da educação, saúde, urbanismo, aposentadorias e, de maneira mais geral, da seguridade, mostram que as intervenções do mercado prevalecem cada vez mais sobre as políticas sociais, mas também que a população mais remediada e instruída utiliza melhor certos auxílios fornecidos pelo Estado e sabe obter vantagens e, ainda, que a crise da escola pública está ligada em parte pelo envelhecimento de sua pedagogia orientada pelas necessidades da sociedade do que para as demandas dos professores.

Conforme o autor:

a mudança na concepção da escola é por demais profunda para depender totalmente dos acasos da conjuntura política. Não se voltará a uma concepção do ensino como socialização, já que os sistema social, a sociedade, já não oferece a solidez de outrora e a individualização da aprendizagem, e portanto a ajuda trazida às iniciativas de cada aluno, já estão sendo praticadas no ensino hoje (TOURAINE ,2007, p.81).

Conforme TOURAINE (2007), a concepção de educação como fator de socialização e a idéia complementar de que esta bem-sucedida cria indivíduos livres e responsáveis prosperou por muito tempo, baseada no monopólio de fato dos liceus públicos, na boa qualidade profissional dos professores e em uma situação econômica que assegurava à grande maioria dos alunos um lugar no mundo adulto. Embora esse discurso da concepção escolar ainda esteja bem vivo, está batendo em retirada devido às inúmeras queixas. Não se pode considerar o aluno apenas como um futuro membro da sociedade. Não se pode recusar a levar em consideração a situação psicológica, social e cultural dos alunos. Com esta recusa, aumentam-se os privilégios dados que pertencem a um meio educado, que gozam das melhores informações e estão, portanto, em situação de elaborar projetos para o futuro. 
È fundamental pensar na relação escola e trabalho nos grupos populares, visto que na formação identitária, o trabalho é prioritário na vida dos jovens, e é a partir dele que os jovens podem pensar seu projeto de vida. O trabalho representa ainda que há precariamente uma possibilidade de saída para essa fase de vida (ARPINI, 2003, p.165).

Os jovens sonham em formar-se, ter uma profissão, no entanto ao analisar a relação escola e trabalho, verifica-se que muitas vezes o trabalho se sobrepõe à escola, pois responde a uma necessidade presente e emergente, como foi verificado nas entrevistas com os pais dos jovens que não freqüentam mais as escolas nos Distritos do Grajaú e do Jardim Ângela.

$\mathrm{O}$ estudo mostra que os jovens que deixaram de freqüentar a escola trabalham exercendo atividades não qualificadas. Para os jovens, a necessidade de trabalhar é o que responde de forma mais prática à possibilidade de ter suas expectativas atendidas, como, por exemplo, ter algum dinheiro para sair, comprar roupas novas, cuidar da aparência, do corpo e, muitas vezes, do filho. O trabalho é valorizado porque possibilita aos jovens as primeiras experiências como consumidor e uma certa autonomia em relação aos seus gastos e às escolhas que são possíveis a partir da sua renda.

ARPINI (2003), tem observado em seus estudos que a relação entre crianças pobres e desprotegidas e o início da atividade laboral marca desde cedo uma nítida diferenciação no processo de inserção escolar, delineando uma perspectiva social em relação ao mundo do trabalho. Analisando esta situação por outro lado, ressalta-se que longe da escola e dos códigos de comunicação cada vez mais básicos para enfrentar os desafios sociais, resta aos jovens pobres a sua exclusão crescente de tudo o que a sociedade espera e tem a oferecer aos cidadãos. Nesse sentido, CASTELLS ( 1999)refere-se à desfiliação social que os jovens vivem ao romperem cada vez mais com os canais de acesso à cultura dominante, pois, privados da formação escolar mínima, o trabalho tão esperado também fica marginalizado, fazendo com que possam aspirar às oportunidades cada vez menores para si, restringindo cada vez mais seus projetos futuros.

Para reverter essa situação são necessárias políticas sociais comprometidas com a reversão dessa corrente, que os exclui do sistema social, e com a oferta de 
opções de escolhas para realizarem projetos, sonharem, pois somente assim existirá de fato um caminho a ser seguido, porque do contrário não haverá saídas possíveis, e os jovens não terão um projeto viável para o futuro (ARPINI, 2003).

A sociedade apresenta um modelo de projeto de futuro para crianças e adolescentes considerado o esperado, o qual, porém, convive com outro que sobrevive de uma maneira diferenciada. Há um modelo para os adolescentes que pertencem aos grupos econômicos e culturais que têm acesso aos bens e outro para aqueles dos grupos empobrecidos, para os quais não existe nenhuma garantia de acessibilidade. Para os primeiros a saída está na escola, sendo por meio dela que os pais esperam que seus filhos alcancem o sucesso, realizando-se profissionalmente; e é pela universidade que a maioria pretende concretizar o seu futuro. Esses jovens possuem uma formação escolar definida que é desde cedo individualista e competitiva, visando aos desafios de passar no vestibular e competir no mercado de trabalho. "Assim se confirma um modelo que prolonga cada vez mais a adolescência e a entrada no mundo do trabalho" (ARPINI, 2003, p.168).

No caso em estudo, os discursos do sujeito coletivo dos jovens, dos pais, professores e profissionais de saúde mostram a juventude como possibilidade de mudanças, uma fase de transição, de sonhos e enfatizam a importância do projeto para transformá-los em sujeitos autônomos. Os planos para o futuro dos jovens demonstram a busca pela concretização dos direitos básicos, como a garantia da escolaridade, ter um emprego ou constituir família.

Os discursos dos jovens estudantes e não estudantes mostraram, no caso dessa pesquisa, que os sonhos referem-se ao desejo de terminar os estudos, formar-se em uma profissão, trabalhar, ter uma casa e constituir família. "Cai por terra o clássico imaginário do jovem contestador, rebelde, engajado, participativo". O jovem brasileiro quer emprego. Seus maiores sonhos são materiais. Seus principais valores são família, saúde, trabalho e estudo. "É um jovem que ainda não conseguiu superar as barreiras das necessidades básicas” (FOLHA DE S. PAULO, 2008, p. Especial 1).

Uma outra questão que pôde ser verificada nos discursos dos jovens e dos profissionais de saúde foi a gravidez na adolescência e o consumo de drogas. Estas interferem no projeto de vida dos jovens e indicam o quanto eles consideram essas questões como próprias dessa fase de vida. Ser jovem é não usar drogas e não ter 
medo de ser feliz, e, hoje, os jovens estão se comportando como um adulto, as meninas de 12 anos já estão grávidas, ou ser jovem não é tão bom quando se está grávida e tem filhos, aí o futuro está condenado, você fica cuidando do filho.

Os argumentos presentes nos discursos expressam conflitos que evidenciam que neste período ocorrem intensas modificações na vida dos adolescentes, caracterizado pela busca de novos desafios, dentre os quais as drogas podem estar presentes.

Na busca de novos desafios, os jovens se deparam, no mundo contemporâneo, com as numerosas transformações sociais decorrentes da tecnologia e da expansão ilimitada do capitalismo. A felicidade, nos dia atuais, relaciona-se com a eficiência técnica da produção, ou seja, é determinada pelo mercado e pelo consumo. Dessa forma, conforme BOAVENTURA SANTOS (1995, p.10), nas sociedades atuais, quando há falta de referências para a construção ético-moral, passa-se a viver: “ da contradição entre os princípios de emancipação, que continuaram a apontar para igualdade e a integração social e os princípios de regulação, que passaram a gerir os processos de desigualdade e de exclusão produzidos pelo próprio desenvolvimento capitalista."

No Brasil essa situação é mais complexa e resulta em uma realidade racionalizada pela relação custo-benefício, na qual a miséria se alastra e os vínculos sociais são rompidos. Nesse contexto, as drogas surgem prometendo novas possibilidades. Assim, na segunda metade do século XX, as drogas assumem uma condição estratégica, pois em condições históricas de um mundo quase inteiramente cientificizado, o desamparo do sujeito atinge proporções insuportáveis (FEFFERMANN, 2006).

A sociedade, todavia, permite o uso de algumas drogas psicoativas, mas estabelece limites entre as lícitas e as ilícitas, sempre em relação a um momento histórico cultural.

No contexto sociopolítico e econômico atual, o uso das drogas pode ser analisado também como fenômeno da cultura de consumo. Com a globalização, ocorre a desvinculação do sistema financeiro da base material da produção, tornando propício o crescimento de grandes proporções do tráfico de drogas, que se insere na economia global. Assim, "a procura e o consumo de drogas geram e asseguram 
enorme rendimento e altíssimo acúmulo de capitais, convertendo o tráfico de drogas no segundo grande negócio mundial -depois das armas - capaz de destruir a imagens de países e redefinir mapas políticos" ( FEFFERMANN, 2006, p.27).

Segundo FEFFERMANN (2006), o tráfico de drogas "é um protótipo da sociedade de consumo, ao expressar toda a violência embutida nesta e produzir ainda mais violência. A droga talvez seja o tema que melhor revele a sociedade contemporânea: é abrangente, multifacetada, lúdica e cruel" (FEFFERMANN, 2006, p. 35).

No que se refere à gravidez não planejada como um dos principais problemas que afetam a vida dos jovens das regiões de estudo, observa-se nos discursos que os jovens têm consciência de que a juventude é uma fase na qua, devem se preparar para as grandes responsabilidades do mundo adulto, entre elas casar e ter filhos e que enfrentam ou enfrentarão dificuldades no presente e no futuro ao assumirem responsabilidades de uma gravidez na adolescência.

No entanto, cada vez mais cedo os jovens tornam-se sexualmente ativos, segundo estudo do Unicef (2002), dos adolescentes brasileiros com faixa etária entre 12 e 17 anos, 32,8\% já haviam tido relações sexuais. Destes, $61 \%$ eram homens e $39 \%$ mulheres. Segundo IBGE (2000), 9,5\% de adolescentes entre 15 e 19 anos ( $82 \%$ mulheres e $18 \%$ homens) vivenciam algum tipo de união, com vida sexual.

O aumento da taxa de fecundidade entre mulheres jovens é também um importante aspecto a ser considerado. Conforme MS ( 2006), entre as mulheres como um todo se assistiu nas últimas quatro décadas a um decréscimo na taxa de fecundidade, sendo em 1940 a média nacional de 6,2 filhos, em 2000, passando a ser 2,3, filhos, entre adolescentes e jovens, o sentido é inverso. Desde a década de 1990 a taxa de fecundidade entre adolescentes aumentou $26 \%$.

A gravidez na adolescência é um tema polêmico e controverso nos debates sobre saúde sexual e saúde reprodutiva dos jovens. Em geral, é considerada uma situação de risco e um elemento desestruturador da vida dos adolescentes e, em última instância, um elemento determinante na reprodução do ciclo de pobreza das populações, ao colocar impedimentos na continuidade de estudos e no acesso ao mercado de trabalho, sobretudo entre as adolescentes (MS, 2006, p.17). 
$\mathrm{Na}$ reflexão crítica dessa questão é preciso considerar a gravidez na adolescência como um acontecimento associado a diversos fatores sociais e pessoas e familiares. Deve-se considerar que há importantes distinções entre a gravidez ocorrida no início da adolescência (10 a 14 anos) e aquelas que ocorrem nas demais faixas etárias o que exige uma análise complexa da questão e suas particularidades ( MS, 2006, p.18)

A gravidez não planejada, quando indesejada, pode revelar-se um grave problema para a saúde sexual e reprodutiva de adolescentes e jovens, como mostram os dados referentes ao número de atendimentos decorrentes de aborto no SUS, bem como nos índices de óbitos maternos juvenis (MS, 2006). Segundo o Datasus, o maior percentual de nascidos mortos é registrado na faixa etária de 10 a 14 anos, com um percentual de 135 (1999). Os dados também mostram que os nascidos mortos, filhos de mulheres de 10 a 14 anos, são inversamente proporcionais aos anos de escolaridade dessas mães, isto é, tendem a ser maiores quanto menor for o nível de escolaridade, que, por sua vez, está diretamente relacionado à pobreza e ao acesso aos direitos sociais (MS, 2006, p.21)

Esta realidade multicausal, revela deficiências na implementação de políticas públicas, exigindo um movimento do governo e da sociedade civil para promover a saúde e o desenvolvimento da juventude. O acesso à educação e aos serviços de saúde é de suma importância, sendo a adolescente com maior escolaridade e maiores oportunidades de obtenção de renda menos propensa à gravidez não planejada (MS,2006)

Constatamos no estudo que os jovens relatam em seus discursos dificuldades de acesso à educação e que os profissionais de saúde referem não ter ações e projetos de promoção da saúde para os jovens nas Unidades de Saúde. Quando os jovens freqüentam as Unidades de Saúde, participam dos grupos de Planejamento familiar e do Programa Municipal Mãe Paulistana, destinados às jovens que já estão grávidas. A gravidez não planejada, conforme as jovens mães e jovens pais entrevistados, compromete o futuro e seus projetos. A evasão escolar pode ser apontada com uma das conseqüências da gravidez precoce, sendo difícil a reinserção posterior da adolescente no sistema educacional. Assumir as responsabilidades paternas, no caso 
dos rapazes, também pode significar a interrupção da educação formal, o que foi verificado neste estudo.

Segundo BERQUÓ E CAVENAGHI (2005), as possibilidades de permanência de adolescentes mães na escola são muito menores do que entre adolescentes que não têm filhos. Analisando os dados do Censo 2000, as autoras mostram que, entre as adolescentes na faixa dos 10 aos 19 anos de idade que estavam na escola, na época do Censo, apenas $20 \%$ daquelas que têm filhos estão na escola. Entre adolescentes sem filhos, na mesma faixa etária, o percentual é de $80 \%$. As chances diminuem segundo as condições econômicas e tornam-se ainda menores para as jovens mais pobres, negras, com menos anos de estudo e trabalham fora de casa (BERQUÓ E CAVENAGHI, 2005).

A grande maioria dos jovens geralmente tem pouco acesso à informação a respeito de sexualidade e reprodução, e muitas vezes têm dificuldades para dizer não ao sexo indesejado ou negociar a prática do sexo seguro. A informação e a educação sexual de qualidade fornecem ao adolescente condições para a escolha do momento apropriado para iniciar a vida sexual segura, saudável e prazerosa.

O excesso de erotização, o uso de álcool e os comportamentos de risco exibidos pelos personagens da mídia transformam-se em modelos, muitas vezes copiados por adolescentes como representação de status socioeconômico, beleza, sucesso e maturidade. A sociedade, que autoriza e estimula o consumo desenfreado, não oferece condições de emprego e segurança financeira para os jovens; dessa forma, frustrados, sem esperanças para o futuro buscam, formas de compensação e alternativas que podem constituir riscos à sua vida. Nessa faixa etária, muitas vezes a gravidez pode estar associada com o desejo de se tornar mãe e de constituir família (CAVASIN, 2004).

A gravidez na adolescência muitas vezes está associada com a situação de vulnerabilidades social, bem como com a falta de informação e acesso aos serviços de saúde. Segundo MS (2006), alguns estudos, têm explorado a relação entre gravidez na faixa etária de 10 a 14 anos e a ocorrência de violência sexual, e outros estudos, como de CAVASIN (2004), não contestam essa hipótese. Para muitos adolescentes, o sexo está ligado à violência, coerção e abuso, muitas vezes cometidos 
por membros da própria família ou adultos que com ele possuem algum tipo de relação privilegiada.

A incorporação do enfoque de gênero nos programas de saúde sexual e reprodutiva para melhorar a qualidade da atenção e da vida das mulheres e homens, na esfera da sua saúde sexual e reprodutiva, é considerada fundamental. Para. DIAZ \& DIAZ (1999) a baixa auto-estima e o papel de submissão das mulheres põem a mulher em uma condição de vulnerabilidade para adquirir doenças sexualmente transmissíveis e/ ou ter uma gravidez não desejada, ou para ter de aceitar o relacionamento sexual contra sua vontade.

\section{A VIOLÊNCIA NAS ESCOLAS}

A noção de incivilidade considerada matriz para análise da violência escolar, tem uma forte repercussão nos estudos realizados na França (PERALVA,1997). Conforme ABRAMOVAY e CASTRO (2006)

\footnotetext{
As incivilidades consistem em infrações à ordem estabelecida que ocorrem na vida cotidiana. Mesmo não sendo aparentemente graves, são atos - como agressões verbais, xingamentos, atos de indisciplina, abuso de poder etc. - que têm o potencial de desorganização da ordem coletiva e das referências de sentido individuais, destruindo laços sociais, fomentando sentimento de insegurança, fragilizando instituições, afetando a experiência e confiança no outro (ABRAMOVAY e CASTRO, 2006, p.50).
}

O termo incivilidade é considerado por DEBARBIEUX (2001), um conceito provisório, aguardando superação. DEBARBIEUX (2001) alerta que o termo não deve servir para minimizar a violência e a delinquiência. "Contudo também não deve servir para superestimá-la, ao generalizá-la, nem para aliviar a representação de insegurança de um possível exagero, ou para confundir todo o questionamento da ordem com uma desordem intolerável, insensata, resultando no crime ou no delito" DEBARBIEUX (2001,.179). Dessa forma o autor sugere substituir o termo incivilidade por microviolência para qualificar certos atos de violência que ocorrem nos processos interativos no contexto escolar.

Conforme ABRAMOVAY et al (2003) a extensa revisão de estudos sobre violência mostra que pesquisas realizadas na Inglaterra (HAYDEN e BLAYA, 2001) têm dificuldade de conceituar a violência escolar, uma vez que o termo violência não 
é comumente usado para qualificar certos atos praticados por professores contra alunos ou vice-versa, por suas conotações emocionais. Segundo a autora termos como "agressividade", "comportamento agressivo", "bullying”e "disruption" seriam mais apropriados para lidar com certas situações do cotidiano escolar (ABRAMOVAY et al, 2003, p.54).

O bullyling "compreende todas as atitudes agressivas, intencionais repetidas, que ocorrem sem motivação evidente, adotada por um ou mais estudantes contra outro (os), causando angústias, sendo executado dentro de uma relação desigual de poder. É considerado um problema social grave e complexo, provavelmente o tipo mais freqüente e visível de violência juvenil” (TAQUETTE,2007, p.80).

Pesquisas realizadas pela Unesco no Brasil, segundo TAQUETTE (2007, p.80) demonstram que , aproximadamente, $60 \%$ dos jovens na faixa etária de 14 a 19 anos de idade foram vítimas de algum tipo de violência nas unidades escolares, nos últimos anos, sendo o bullying, uma das formas naturalizadas de violência que vem ganhando destaque.

A partir dessas reflexões pode-se constatar a presença dos diversos tipos de violências nas escolas nos relatos dos atores entrevistados. $O$ bullying é evidenciado nos relatos dos educadores quando se referem à chamada violência natural, normal presente nas escolas.

Comparando as opiniões do educadores com as dos jovens estudantes e não estudantes, confirma-se que as microviolências estão presentes no cotidiano escolar. Os jovens referem brigas entre alunos, agressão por colegas,brigas com colegas e xingamentos. O tipo de violência sofrida pelos jovens na escola foram briga entre colegas $(34,0 \%)$, agressão física $(32,0 \%)$ sendo que este tipo de agressão é mais mencionado na faixa etária de 10 a 14 anos; xingamento $(18,0 \%)$ e preconceito, discriminação $(4,0 \%)$.

Entre os principais problemas existentes com os alunos, citados pelos educadores, encontram-se: indisciplina dos alunos, desrespeito com os funcionários e a violência.Os educadores consideraram que existe violência nas escolas $(58,6 \%)$ citam: agressão verbal $(25,7 \%)$, brigas entre os alunos $(24,3 \%)$, violência natural, normal $(12,9 \%)$ e vandalismo, depredações $(5,7 \%)$, brigas do lado de fora $(4,3 \%)$, alunos agressivos $(4,3 \%)$, tráfico no entorno $(2,9 \%)$ 
Os jovens também são vítimas da violência "dura" ou físicas,conforme mencionado pelos jovens que deixaram a escola, como estupro na saída da escola referidas por $(6,3 \%)$ dos jovens que deixaram a escola e o tráfico presente nos relatos dos educadores.

Quanto às explicações sobre as causas da violência escolar, na revisão da literatura realizada por ABRAMOVAY et al , 2003 sobre o tema, os atos de violência estão associados a fatores externos e internos. Os fatores externos estão resumidamente relacionados às explicações de ordem socioeconômica, ao agravamento das exclusões sociais, raciais e de gênero, à perda de referencial entre os jovens, ao surgimento de "galeras", "gangues", "tráfico de drogas", desestruturação familiar, perdas de espaços de sociabilidade entre outros. Os fatores internos seriam: o nível de escolaridade dos estudantes, o sistema de normas e regras, a disciplina dos projetos políticos e pedagógicos, a quebra do pacto de convivência interna o desrespeito de professores com os alunos e vice-versa, a má qualidade de ensino, a carência de recursos (ABRAMOVAY et al. , 2003, p.54).

Conforme ABRAMOVAY et al. (2003:55), essas variáveis se inserem em um conjunto de ações dificuldades e tensões vividas no cotidiano escolar. "A dificuldade de estabelecer relações entre os alunos, a escola e a comunidade contribuem para o surgimento de violência no interior da unidade escolar."

Sendo assim os principais problemas relatados pelos educadores presente no ambiente escolar, como a indisciplina, o desinteresse e a falta de motivação dos alunos, a defasagem no aproveitamento escolar, a falta de espaço, falta de funcionários, falta de professores, a ausência dos pais, o excesso de alunos, e condição dos prédios, a escassez de material didático, a falta de perspectivas para os jovens e o consumo de álcool e drogas enquadram-se nas variáveis internas e externas citadas e podem explicar as causas da violência escolar referida pelos educadores e jovens.

Constata-se que aos problemas existentes relatados quando analisados de acordo com as faixa etárias estudadas são diferentes embora tenham a s mesmas explicações. Assim os problemas apresentados pelos jovens da faixa etária de 10 a 14 anos referem-se ao aprendizado, à indisciplina, à agressividade no relacionamento,à falta de compromisso e de interesse, enquanto que, na faixa etária dos 15 aos 19 
anos, os problemas referem-se ao desinteresse com a aprendizagem, à gravidez precoce,ao álcool fumo, e às drogas e à falta de perspectivas para os jovens.

As reflexões apresentadas trianguladas com as informações obtidas no estudo reafirmam que o caráter difuso e mutável da violência aliado às intensas transformações da vida contemporânea e seus desdobramentos, tais como a criminalidade, sobretudo nas grandes metrópoles brasileiras, segundo GUIMARÃES (2005); ABRAMOVAY e CASTRO (2006) vem gerando novas formas de organização da vida cotidiana, envolvendo e determinando alterações significativas na dinâmica social e institucional atingindo a escola de forma particular. Sendo assim, como analisa ABROMOVAY e RUA (2002, p.78), "as questões relativas à violência escolar, não podem ser tratadas de modo isolado, mas sim em íntima articulação com a dinâmica educativa da escola como um todo, "dentro e fora" dela, especialmente porque os jovens trazem para o cotidiano escolar, de uma forma aberta, sua maneira de ser, sua linguagem e sua cultura.

\section{A VIOLÊNCIA NOS TERRITÓRIOS}

Os jovens estudantes e não estudantes gostam do bairro onde moram, assim como os pais dos jovens que não mais freqüentam a escola. Os jovens e os pais ressaltam a importância dos amigos da amizade e da solidariedade. No entanto relatam que os principais problemas existentes nas regiões de estudo, são a falta de infra estrutura, a violência, a ausência de lazer e cultura, o consumo e tráfico de drogas e a falta de segurança. As violências existentes referem-se à violência doméstica e sexual, tráfico e consumo de drogas, aos assassinatos e ação do crime organizado (Quadro11 e 13).Esse quadro indica o sentimento de pertença e os conflitos vividos pelos jovens n referenciados por DUBET (19994) na articulação da identidade integrativa, do mercadoe da subjetividade.

Na lógica da integração, "o ator define-se pelas suas pertenças, visa mantê-las e fortalecê-las no seio de uma sociedade considerada então como um sistema de integração".no caso, o bairro, a escola, os grupos culturais e as entidades com seus projetos. Na lógica estratégica, "o ator tenta realizar a concepção que tem dos seus interesses numa sociedade concebida então como um mercado."Os jovens 
entrevistados valorizam os seus estudos, almejam ter um trabalho digno e constituir famílias. Na lógica da subjetividade, "o ator representa-se como um sujeito crítico confrontado com uma sociedade definida por um sistema de produção e de dominação" (DUBET,1994, p.113).

Os jovens das regiões de estudo estão integradas na sua comunidade, têm como projeto de vida o trabalho e a constituição da família, portanto são projetos que se inserem-se no âmbito privado, ou seja da família.Estas também são as expectativas dos pais. Para os educadores e profissionais de saúde e lideranças e gestores os jovens são a esperança de uma sociedade melhor, têm potencialidades que precisam ser desenvolvidas, no entanto ressaltam que não têm oportunidades de acesso à educação, esporte, cultura e lazer e muitas vezes os seus projetos de vida são inviabilizados levando-os a escolher caminhos que comprometerão o futuro.

No decurso da socialização primária, infantil os jovens apenas incorporam as expectativas de outrem, no caso dos pais e da suas comunidades. Na perspectiva da lógica estratégica a integração do sistema é substituído pela sua regulação, pela necessidade de manter as regras do jogo para que este seja possível. "A civilidade e a pertença ao grupo são, já não uma norma, mas uma forma do interesse bem entendido, uma condição necessária à prossecução dos objetivos" (DUBET,1994, p.123). A ação estratégica só é possível com o apoio de uma integração mínima. "Sem uma lógica de integração simultânea, a concorrência tornar-se-ia uma guerra" (DUBET,1994, p.123).

A família é a escola e os amigos são fundamentais para os jovens nessa fase de vida, para orientá-los, solucionar dúvidas decorrentes das transformações biológicas e do despertar da sexualidade e com os riscos que presenciam no cotidiano. A família, a escolas e os amigos bem como as ações coletivas existentes nas regiões contribuem para a formação da subjetividade, mas na lógica de uma identidade legitimadora: "Introduzida pelas instituições dominantes da sociedade com o intuito de expandir e racionalizar sua dominação em relação aos atores sociais (CASTELLS, 1999, p.24).

Embora se evidencie nos discursos dos atores entrevistados que as ações coletivas nas regiões tenham como objetivos desenvolver sujeitos autônomos, estas ainda, em sua maioria são voltadas para a satisfação das necessidades de 
sobrevivência e não há participação dos jovens, no sentido de transformação para constituir uma identidade de projetos conforme definida por CASTELLS (1999, p.24): "quando os atores sociais utilizando-se de qualquer tipo de material cultural ao seu alcance, constroem uma nova identidade capaz de definir sua posição na sociedade e, ao fazê-lo, de buscar a transformação de toda a estrutura social”.

Nesse sentido, segundo (ZIONI e WESTPHAL (2007)

Na contemporaneidade a questão social não diz respeito à uma cidadania abstrata, mas sim à criação de espaços onde essa cidadania possa se enraizar em experiências individuais, concretas. Não se trata mais de integrar e socializar indivíduos para transformá-los em cidadãos, e sim criar condições sociais "que permita a cada pessoa acender com suas particularidades à cidadania e construir sua vida com o máximo de autonomia , tornando-se sujeitos de direitos. (p.33).

A construção da identidade está estritamente relacionadas a um contexto social, a política da identidade deve ser situada historicamente (CASTELLS,1999). Para o autor o surgimento da sociedade em rede traz à tona processos de construção da identidade induzindo novas formas de transformação social, isto ocorre porque a sociedade em rede está fundamentada na disjunção sistêmica entre o local e o global para a maioria dos indivíduos e grupos sociais e também na separação, em diferentes estruturas de tempo/espaço, entre poder e experiência (CASTELLS (1991, p.27).

Segundo TOURAINE (2007)“ o espaço que foi o das relações entre a "sociedades" é invadido hoje pelas forças de guerra, do dinheiro, do medo e da violência, os espaços públicos não estão vazios, mas quase não é mais ocupado pela política representativa" Ficamos marcados pela idéia de que as sociedades modernizadas davam importância sempre maior à sociedade civil, e, portanto aos atores sociais. De forma que a política tornava-se cada vez mais próxima dos conflitos e dos movimentos sociais (p.75).

Para TOURAINE (2007) "a idéia de que auto-regulação institucional da sociedade enfraqueceu-se- quando não está em via de desaparecer. "A estátua da sociedade, que fora erguida no coração do espaço público, está hoje reduzida a cacos" 
Conforme TOURAINE (2007):

Diante das forças bélicas e de todas as formas de violência não cremos mais na ação política e sindical. Apenas as forças que repousam sobre uma legitimidade não-social, como a defesa dos direitos humanos,podem opor-se com sucesso às forças bélicas, que tão pouco estão fundadas em princípios propriamente sociais, definidos em termos do interesse geral da sociedade (TOURAINE, 2006, p.76).

Sendo assim, na atualidade, o conhecimento da participação na esfera pública exige uma atualização da representação sobre os movimentos sociais e participação. "Exige o reconhecimento de que a fragmentação da sociedade, o declínio das instituições, as novas formas de sociabilidade e de inserção social, os diferentes espaços de construção de identidade torna o tema participação mais complexo do que a existência dos canais formais de representação e de apresentação de demandas" (ZIONI e WESTPHAL, 2007, p. 33).

Por outro lado, conforme CHARLOT (2000) a essência do ser humano é antes de tudo social, o que significa afirmar que o homem se constitui na relação com o outro, portanto o pleno desenvolvimento ou não das potencialidades dos jovens vai depender da qualidade das relações sociais do meio no qual eles se inserem, e conforme CHARLOT (2000), todo ser humano é sujeito, deve-se portanto considerar as várias formas de se construir como sujeito " e uma delas se refere ao contexto de desumanização, nas quais o ser humano é 'proibido de ser', privado de desenvolver suas potencialidades, de viver plenamente a sua condição humana" (DAYRELL, p. 43). Segundo o autor, não é que eles não se construam como sujeitos, ou sejam pela metade, "mas sim que eles se constroem como tais nas especificidades dos recursos que dispõem" (p.43).

Os jovens que participaram do estudo, tem amigos, gostam dos seus pais, do local onde moram, da escola, visitam amigos, dormem, brincam na rua, jogam futebol empinam pipas, cuidam da casa, dos sobrinhos, namoram, outros estão casados têm filhos, fazem "bicos par sobreviver" ou exercem funções não qualificadas. Todos têm desejos e sonham com uma vida melhor, com projetos para o futuro. Dessa forma cada um deles vai construindo e sendo construído como sujeito. "Um ser singular que se apropria do seu social, transformando em representações, aspirações e práticas, que interpreta e dá sentido ao seu mundo e às relações que mantém" (DYRELL, 2003, p. 24). 
CONCLUSÃO 


\section{CONCLUSÃO}

Este estudo foi desenvolvido com o objetivo de analisar e comparar os processos que orientam as ações coletivas e as experiências participativas de promoção da saúde dos jovens, realizadas pelas organizações governamentais e não governamentais para o enfrentamento e resistência à violência nos Distritos Administrativos do Grajaú e Jardim Ângela do município de São Paulo, visando contribuir para a construção de uma cultura de paz e implementação de políticas públicas para a juventude local.

A hipótese inicial era a de que a existência de políticas públicas e de ações coletivas integradas com a participação dos jovens no distrito administrativo do Jardim Ângela do município de São Paulo, tinha contribuído para reduzir os coeficientes de mortalidade por homicídios nessa mesma população no referido distrito. O distrito do Grajaú, com características semelhantes em termos de vulnerabilidade social ao do Jardim Ângela, não tem alcançado os mesmos resultados em relação à redução da mortalidade por homicídios na população jovem, em função da desarticulação e fragmentação das políticas públicas e das ações coletivas locais e da falta de protagonismo dos jovens. Esta hipótese se confirmou parcialmente, uma vez que, no decorrer do estudo, verificou-se que nos dois distritos administrativos ocorreu uma tendência de queda nas taxas de mortalidade por agressões/homicídios, caracterizada pelos eventos descritos pela Classificação Internacional de Doença - CID 10 nos itens de X85 a Y09. Esta taxa apresentou o menor valor em 2006 desde 1996 e tem refletido uma tendência persistente de queda nos últimos anos no município de São Paulo.

Por meio dos dados secundários e das entrevistas com os atores que participaram desse estudo foi possível conhecer as condições de vida e os principais problemas que afetam os jovens nas regiões e as propostas para solucioná-los

De acordo com os critérios de agrupamento da condição de vulnerabilidade, verificamos que os grupos de alta e altíssima privação e a presença de jovens reunidos correspondem, nos distritos de Grajaú e Jardim Ângela, a 35,57\% e 37,59 $\%$, respectivamente, enquanto que para o total do município corresponde a $11,15 \%$ 
associando a esse grupo etário, uma alta condição de vulnerabilidade social nas áreas de estudo.

Os principais problemas verificados nas regiões de estudo foram: falta de infra-estrutura, a violência, falta de áreas de lazer e cultura, o consumo do álcool e drogas, o tráfico de drogas e transportes. Foram também referidos ausência do poder público, moradia e urbanização precárias, falta de segurança, falta de cuidado com o meio ambiente e a exclusão social

Os principais tipos de violência existentes nas duas regiões, para os pais, lideranças, educadores e profissionais de saúde estão relacionadas ao consumo de álcool e drogas, e ao tráfico seguidos de violência doméstica, violência sexual e estupros, violência contra criança e os assassinatos. Foi citado o crime organizado na cadeia causal do tráfico de drogas. Os assassinatos também podem relacionar-se com o consumo e tráfico de drogas nas regiões. Pelos relatos dos jovens constata-se que a principal violência é a doméstica.

No estudo foram identificadas as entidades que atuam nos distritos administrativos do Grajaú e do Jardim Ângela e adotada uma tipologia para classificá-las. Conforme a tipologia adotada verificou-se que no Grajaú predominam as Associações de Bairro (33,3\%) e no Jardim Ângela as Entidades Assistenciais $(61,9 \%)$ bem como uma maior atuação de ONG/Oscip no Grajaú.

As maioria das entidades dos distritos administrativos desenvolvem projetos e ações destinados aos jovens na faixa etária de 10 a 19 anos na área de participação comunicação e cidadania $(57,4 \%)$. Verificam-se projetos na área educacional $(44,4 \%)$, sendo um percentual maior no DA do Jardim Ângela $(60,6 \%)$; na área de desenvolvimento psicossocial $(35,2 \%)$, sendo também o percentual maior no Jardim Ângela $(47,6 \%)$ e ainda projetos profissionalizante, esportivo, ambiental, na área de saúde e assistencial.

Nas escolas das regiões predominam os projetos da Área de Participação, comunicação e cidadania $(60,0 \%)$. Na seqüência os projetos da Área Educacional (50,0\%), Ambiental (42,9\%), Área da Saúde (37,1\%), Área de Desenvolvimento psicossocial (18,6\%) e Esporte e Lazer (12,9\%).

As Unidades de Saúde desenvolvem projetos e ações predominantemente na área da saúde $(93,6 \%)$. Foram citados também projetos na área cultural $(15,2 \%)$ e 
educacional $(9,1 \%)$. Projetos e ações da área cultural foram referidos como correntes no DA do Grajaú $(23,1 \%)$. Na área ambiental $(6,1 \%)$ ocorrem alguns projetos nos dois distritos pesquisados. Projetos e ações na área de desenvolvimento psicosssocial (10\%), foram referidos no Jardim Ângela e os esportivos referidos, no Grajaú $(7,7 \%)$.

Quanto à participação dos jovens nos projetos e ações, verificou-se que estes não participam, e quando o fazem, não atuam como protagonistas.As iniciativas e projetos existentes nas regiões de estudo não alcançam os jovens entrevistados, que residem em áreas de grande vulnerabilidade social. As atividades desses jovens se restringem à casa, às praças e ruas dos bairros onde residem.

$\mathrm{Na}$ análise da rede de proteção aos jovens nos distritos, constatou-se que os projetos, programas e ações desenvolvidos nas regiões de estudo, em última instância buscam tirar os jovens das ruas por meio de atividades diversas que preencham o tempo ocioso. As intervenções estão voltadas principalmente para a redução do risco de violência, referido por um terço das entidades, seguidas pelo foco voltado para a educação, cultura, desenvolvimento socioeducativo, que muitas vezes incluem programas educacionais e culturais, a prática de esportes e o lazer, principalmente.

Focalizando os jovens, verificou-se que os estudantes e não estudantes gostam do bairro onde residem, consideram o bairro tranqüilo, moram na região desde que nasceram, têm amigos e bons vizinhos. Embora se observe o sentido de pertencimento dos jovens às famílias e ao bairro, estes não estão envolvidos com o território, no sentido de atuar sobre sua realidade para modificá-la.

Apesar de os jovens considerarem os bairros tranqüilos, os dados indicam que o cotidiano dos jovens está marcado pela violência. A aparente tranqüilidade pode ser explicada pelo fato de os jovens terem crescido e convivido com uma história de violência nas regiões, em especial a do Jardim Ângela, e isto pode levá-los a experimentar um certo sentimento de "normalidade" ao conviverem desde cedo com situações de violência nas regiões.

Nos discursos dos jovens constatam-se algumas contradições no que se refere às experiências dos jovens com a violência: ora a violência parece estar distante, sendo os bairros considerados bons, tranqüilos e seguros; ora a violência parece estar muito próxima, com relatos mostrando que alguns jovens já sofreram muito com ela. 
No entanto, fica evidente nos discursos que os jovens convivem com diversos tipos de violência nas regiões onde moram, destacando-se a violência doméstica.

Os discursos mostram as diferentes formas e expressões da violência no cotidiano dos jovens, ou seja, estão presentes nos discursos: a violência estrutural, a violência doméstica e a violência infanto-juvenil. Estão presentes ainda, a violência racial e institucional. Como definem os jovens: Violência é algo ruim, desagradável que deixa marcas físicas e psicológicas, é também uma violação dos direitos. Violência é tudo o que vivenciamos hoje no mundo.

No estudo evidencia-se que os jovens ao procurarem definir o que entendem por paz, trazem em seus discursos as violências presenciadas e vividas na região e nos seus lares. Para os jovens, a paz é algo que se busca, é uma conquista. É a possibilidade de diálogo, conviver com as diferenças e aceitar o outro. A paz é tida com essencial para viver, e consiste em fazer o bem e na perfeição. Para alguns jovens é não ter violência, não usar drogas e não traficar. Há também jovens que acreditam que a paz não existe.

$\mathrm{Na}$ análise efetuada sobre a escola, a partir dos depoimentos dos estudantes e daqueles que deixaram de estudar, verifica-se que a escola desempenha importante papel na socialização e na sociabilidade dos jovens. É um espaço de convivência com amigos e professores e de aquisição de conhecimentos. As principais dificuldades encontradas referem-se a "bagunça", a indisciplina, brigas entre alunos, a violência interna entre os jovens e às dificuldades estruturais.

No que se refere à juventude em sua a sociabilidade foi dada ênfase pelos atores e entrevistados à importância do lazer, esporte e cultura na formação da visão de mundo, na construção da identidade, no entanto, verificou-se que a sociabilidade dos jovens se dá nas praças e ruas, em casa ocupando-se de trabalhos domésticos, navegando na internet e ainda nas lan-houses .

Predomina entre os jovens a concepção de juventude como fase de transição para a vida adulta e a visão da juventude como liberdade. Os dados mostram a importância dada pelos jovens à sua liberdade individual e à conquista progressiva de uma autonomia, que será alcançada com a entrada no mundo adulto. As expectativas dos jovens são de um futuro melhor. O projeto de vida é estudar e depois conseguir um trabalho, ter um bom emprego e constituir família. Seus principais valores são 
família, estudo e trabalho. Os resultados do estudo mostram que os jovens ainda não conseguiram superar as barreiras das necessidades básicas.

A noção de juventude predominante nos discursos dos pais, lideranças, profissionais de saúde e educadores é entendida como uma fase de transição, de preparação para a vida adulta e de constituição da identidade. Foi considerada uma fase difícil, marcada por conflitos e vulnerabilidades como: gravidez não planejada, consumo de drogas, ação do tráfico e violência.

Nos discursos são ressaltadas as potencialidades dos jovens, contrapondo-se à visão da falta de perspectivas para a juventude da periferia. Para os entrevistados os jovens não têm acesso à cultura, esporte, lazer, educação de qualidade e trabalho . Faltam incentivos, oportunidades e políticas públicas para a juventude da periferia.

Finalmente, foi possível concluir que no Jardim Ângela, diferentemente do Distrito do Grajaú, houve inicialmente uma intensa mobilização da comunidade civil, indignada com os altos índices de violência na região, e que a Igreja Católica representada pela Sociedade Santos Mártires, teve papel fundamental na articulação e na constituição de uma rede de proteção e enfrentamento à violência na região.As Unidades de Saúde com Programa Saúde da família e as escolas têm uma atuação importante na rede.

No Grajaú foi verificada a atuação de várias entidades que se reconhecem, mas estão dispersas no território. Há grupos que estão articulados no território permitindo vislumbrar a possibilidade de integração das diversas ações empreendidas de forma mais sinérgica. As principais entidades articuladoras na região são Cedeca, Projeto Guri, Projeto Anchieta, as escolas e as ONGs, como Instituto Sou da Paz, Cenpec e Instituto Polis- Balaio Cultural, que desenvolvem projetos voltados para os jovens na região.

Finalmente, entre os diversos desafios que se impõem para a prevenção e enfrentamento da violência, destaca-se, neste estudo, a necessidade de promover a participação social dos jovens, especialmente daqueles que vivem em situações de maior vulnerabilidade social, e que os projetos e ações em ambos distritos possibilitem o desenvolvimento desses jovens, no sentido de promover a autonomia e cidadania, considerando-os como sujeitos de direito. 
REFERÊNCIA BIBLIOGRÁFICA 


\section{REFERÊNCIAS BIBLIOGRÁFICAS}

ABAD, M. Crítica política das políticas de juventude. In: FREITAS, M. V. ; PAPA, F. C. (Orgs). Políticas públicas: juventude em pauta. São Paulo: Cortez: Ação Educativa Assessoria, Pesquisa e Informação: Fundação Frieddrich Ebert, 2003.

ABERASTURY, A.; KNOBEL, M. Adolescência normal. Porto Alegre: Editora Artes Médicas, 1982.

ABRAMO, H .W. Considerações sobre a tematização social da juventude no Brasil. Revista Brasileira de Educação, São Paulo, n. 5-6, p. 25-36, 1997.

ABRAMO, H. W. Espaços de juventude. In: FREITAS, M. V.; PAPA, F. C. (Orgs). Políticas públicas: juventude em pauta. São Paulo: Cortez: Ação Educativa Assessoria, Pesquisa e Informação: Fundação Frieddrich Ebert, 2003.

ABRAMOVAY, E. (Coord). Escola inovadoras. Brasília: Unesco: Kellog Foudation, 2003.

ABRAMOVAY, M., et al. Escolas inovadoras: experiências bem sucedidas em escolas públicas. Brasília: UNESCO, 2003.

ABRAMOVAY, M.; CASTRO, M. G. Caleidoscópio das violências nas escolas. Brasília: Missão Criança, 2006. (Série Mania de Educação).

ABRAMOVAY, M.; RUA, M. G. Violências nas escolas. Brasília: UNESCO, 2002.

ADORNO, R. C. F., CASTRO, A. L. O exercício da sensibilidade: pesquisa qualitativa e a saúde como qualidade. Saúde e Sociedade, São Paulo, v. 3, p. 172-85, 1994.

ADORNO, S. A. Criminalidade violenta urbana no Brasil: um recorte temático. BIBBoletim Bibliográfico e Informativo em Ciências Sociais, São Paulo, v. 35, n. 1, p. 3-24, 1991.

ADORNO, S. Crianças e adolescentes e a violência urbana. São Paulo: NEVUSP, 2003. Disponível em: < http://www.nevusp.org/downloads/down076.pdf > . Acesso em 16 jan. 2006.

AGUDELO, S. F. Violência, cidadania e saúde pública. In: BARRADAS, R. R.; BARRETO, M. L.; FILHO, N. A. (Orgs.). Eqüidade e saúde: contribuições da Epidemiologia. Rio de Janeiro: FIOCRUZ: ABRASCO, 1997.

ANDRADE, E. A. Gestão municipal de políticas públicas dirigida à juventude e possíveis aproximações com a promoção da saúde. 2008, 181 p. Dissertação (Mestrado em Saúde Pública) - Faculdade de Saúde Pública da Universidade de São Paulo, São Paulo. 
ARENDT, H. Sobre la violencia. Madrid: Alianza Editorial, 2005.

ÁRIES, P. História Social da criança e da família. Tradução de Dora Flaksman. 2.ed. Rio de Janeiro: LTC, 2006.

ARPINI, D. M. Violência e exclusão: adolescência em grupos populares. Bauru, SP: EDUC, 2003.

ASSIS, S. G. Crianças e adolescentes violentados: presente e perspectivas para o futuro. Cadernos de Saúde Pública, Rio de Janeiro, v. 10, supl. 1, p. 126-134, 1994.

ASSIS, S. G. et al. Violência contra criança e adolescentes: o investimento da comunidade acadêmica na década de 90. In: MINAYO, M. C. S.; SOUZA, E. R. (Orgs) Violência sob o olhar da saúde: a infropolítica da contemporaneidade brasileira. Rio de Janeiro: Fiocruz; 2003.

ÁVILA, L. K. A. Sistematização de um método de captação das necessidades de saúde dos adolescentes com base na promoção da saúde. 2002. Dissertação (Mestrado) - Escola de Enfermagem, Universidade de São Paulo, São Paulo.

AYRES, J. R. C. M. et al. Risco, vulnerabilidade e práticas de prevenção e promoção da saúde. In: CAMPOS, G. W. S. et al (Orgs.). Tratado de Saúde Coletiva. São Paulo: HUCITEC; Rio de Janeiro: Ed. FIOCRUZ, 2006. p. 375-417.

AYRES, J. R. C. M. HIV/Aids, DST e abuso de drogas entre adolescentes: vulnerabilidade e avaliação de ações preventivas. São Paulo: Editoração eletrônica. Casa de Edição, 1996.

AYRES, J. R. C. M. Vulnerabilidade e avaliação de ações preventivas. São Paulo: Casa de Edição, 1996.

AYRES, J. R. C. M. Vulnerabilidade e violência: a resposta social como origem e solução do problema. In: WESTPHAL, M. F.(Org.). Seminário violência e juventude, 2008. No prelo.

AYRES, J. R. C. M. Vulnerabilidade e violência: a resposta social como origem e solução do problema. In: WESTPHAL, M. F.; BIDYLOWSKI, C. ( Orgs). Violência e Juventude, 2009. No prelo.

BAUMAN, Z. Globalização: as consequiências humanas. Rio de Janeiro: Jorge Zahar Ed., 1999.

BERQUÓ, E; CAVENAGHI, S. Increasing adolescent and youth fertility in Brazil: a new trend or one-time event? In: ANNUAL MEETING OF THE POPULATION ASSOCIATION OF AMERICAN (PAA), 2005, Philadelphia, Pennsylvania.

Proceedings... Filadélfia, 2005. Mimeografado. 
BRASIL. Conselho Nacional de Secretários de Saúde. Violência: uma epidemia silenciosa. Brasília: CONASS, 2007. (CONASS Documenta, 15).

BRASIL. Lei Federal No 8.069, de 13 de julho de 1990. Dispõe sobre o Estatuto da Criança e do Adolescente e dá outras providências. Disponível em:

<http://www.planalto.gov.br/ccivil/LEIS/L8069.htm>. Acesso em: 12 jul. 2006.

BRASIL. Ministério da Ação Social. Estatuto da criança e do adolescente. 3.ed. Brasília, 1991.

BRASIL. Ministério da Justiça. CONANDA - Conselho Nacional de Direitos da Criança e do Adolescente.Diretrizes Nacionais para a Política de Atenção Integral à Infância e Adolescência. Brasília, 2001.

BRASIL. Ministério da Saúde (BR). Fundação Oswaldo Cruz. Promoção da saúde: carta de Ottawa, declaração de Adelaide, declaração de Sundsvall e declaração de Bogotá. Brasília (DF): Ministério da Saúde; 1996.

BRASIL. Ministério da Saúde. Secretaria de Atenção à Saúde. Área de Saúde do Adolescente e do Jovem. Marco legal: saúde, um direito de adolescentes. Brasília: Ministério da Saúde, 2005.

BRASIL. Ministério da Saúde. Secretaria de Atenção à saúde. Departamento de Ações Programáticas Estratégicas. Marco teórico e referencial: saúde sexual e reprodutiva de adolescentes e jovens: versão preliminar. Brasília: DF. Editora do Ministério da Saúde, 2006. (Série B. Textos Básicos de Saúde). Disponível em: $<$ http http://portal.saude.gov.br/portal/arquivos/pdf/marco_teorico_referencial.pdf $>$. Acesso em: 30 ago. 2008.

BRASIL. Ministério da Saúde. Secretaria de Atenção à Saúde. Departamento de Atenção Básica. Monitoramento na atenção. Brasília: MS, 2004.

CAMARANO, A. A. et al. Caminhos para a vida adulta: as múltiplas trajetórias dos jovens brasileiros. Última Década, Valparaíso, n. 21, p. 11- 50, dic. 2004.

CAMPOS, G. W. S. A saúde pública e a defesa da vida. São Paulo: Hucitec, 1991.

CARA, R. B. Territorialidade e identidade regional no sul da província de Buenos Aires. In: SANTOS, M. A. A. de S.; SILVEIRA, M. L. (Orgs). Território: globalização e fragmentação. 3. ed. São Paulo: Hucitec- Anpur,1996.

CARDIA, N.; MELO, T. F. Conflito e insegurança escolar na zona sul de São Paulo: relatório final. São Paulo: NEV/USP, 2003. Disponível em: <http://www.nevusp.org/downloads/down057.pdf >. Acesso em: 10 jan. 2006. 
CARICARI, A. M.; CAMARGO, M. T. V. E. F (Orgs). O compromisso da saúde no campo do trabalho infanto-juvenil uma proposta de atuação. São Paulo: FSPUSP: FUNDACENTRO:FINEP, 1999. p. 5-11.

CARRANO P.M. Jovens e escola: sentidos de presença. In: A escola e o mundo juvenil: experiências e reflexões. São Paulo: Ação Educativa, 2003.

CARVALHO, C. A. J. O. Territórios da saúde: uma análise dos seus componentes. S.l., s.d. Disponível em:

$<$ http://www.escola.org/geografia/saude/territoriosaude.html>. Acesso em: 8 nov. 2001 .

CASTELLS, M. A. A era da informação: economia, sociedade e cultura. In: A sociedade em rede. 5. ed. São Paulo: Paz e Terra, 1999. v. 1.

CASTELLS, M.; BORJA, J. As cidades como atores políticos. Novos Estudos, São Paulo, n. 45, p. 152-166, 1996.

CAVASIN, S. (Org). Gravidez entre adolescentes de 10 a 14 anos: estudo exploratório em cinco capitais brasileiras e vulnerabilidade social: relatório de Pesquisa. Rio de Janeiro: ECOS, 2004.

CEBRAP - Centro Brasileiro de Análise e Planejamento. Mapa da vulnerabilidade social da população da cidade de São Paulo. São Paulo, 2004.

CEBRAP - Centro de Estudos da Metrópole; Ministério das Cidades, Secretaria Nacional da Habitação. Assentamentos precários no Brasil urbano. São Paulo, 2007. Disponível em:

$<$ http://www.centrodametropole.org.br/mc/assets/pdfs/assentamentos_web.pdf $>$. Acesso em: 6 jul. 2007.

CHARLOT, B. Da relação com o saber: elementos para uma teoria. Tradução de Bruno Magne. Porto Alegre: Artmed, 2000.

CHESNAIS, J. C. Histoire de la violence. Paris: Éditions Robert Laffont, 1981.

CHIESA, A. M. Autonomia e resiliência: categorias para o fortalecimento da intervenção na atenção básica na perspectiva da promoção da saúde. 2005. p. 96. Tese (Livre- docência) - Departamento de Enfermagem em Saúde Coletiva, Escola de Enfermagem, Universidade de São Paulo, São Paulo.

COMARÚ, F.A. Políticas de habitação e desenvolvimento urbano em municípios saudáveis: o caso de Bertioga. 2004. Tese (Doutorado). - Faculdade de Saúde Pública, Universidade de São Paulo, São Paulo.

COMMITTEE ON THE RIGHTS OF THE CHILD. Adolescent Health and Development in the Context of the Convention on the Rigths of the Child. Prepared 
for the 33rd session of the Committee on the Rights of the Child, 19 May - 6 June 2003. 12 p. Não publicado.

CORREA, S. Implementando o Cairo: avanços no olho do furação. Cadernos do Observatório, Rio de Janeiro, v. 2, n. 1, 2000.

COSTA, J. F. Ordem médica e norma familiar. 2. ed. Rio de Janeiro: Graal, 1983.

COSTA, J. F. Violência e psicanálise. 3. ed. Rio de Janeiro: Edições Graal, 2003.

CRUZ NETO, O.; MOREIRA, M. R. A concretização das políticas públicas em direção à prevenção da violência estrutural. Ciência e Saúde Coletiva, Rio de Janeiro, v. 4, n. 1, p. 33-52, 1999. Disponível em:

<http://www.scielo.br/pdf/csc/v4n1/7129.pdf>. Acesso em: 6 mar. 2005.

DAYRELL, J. T. A música entra em cena: o rap e o funk na socialização da juventude. Belo Horizonte: UFMG, 2005.

DAYRELL, J. T. O jovem como sujeito social. Revista Brasileira de Educação, São Paulo, n. 24, p. 40-52, set.-dez. 2003.

DAYRELL, J. T. O rap e o funk na socialização da juventude. Educação e Pesquisa, São Paulo, v. 28, n. 1, p. 117-136, jan./jun. 2002.

DEBARBIEUX, E. A violência na escola francesa: 30 anos de construção social do objeto (1967-1997) . Educação e Pesquisa , São Paulo, v. 27, n.1, p.163-193, jan.jun. 2001.

DEMO, P. Participação é conquista. São Paulo: Cortez, 1998.

DESLANDES 2004

DESLANDES, S. Drogas e vulnerabilidade às violências. In: MINAYO et al. (Orgs).Violência sob o olhar da saúde: infropolítica da contemporaneidade brasileira. Rio de Janeiro: Editora Fiocruz, 2003.

DESLANDES, S. F. Atenção à criança e Adolescentes vítimas de violência doméstica: análise de um serviço. Cadernos de Saúde Pública, Rio de Janeiro, v. 10, supl. 1, p. 156-167, 1994.

DÍAZ, M.; DÍAZ, J. Qualidade de Atenção em Saúde Sexual e Reprodutiva: Estratégias para Mudanças. In: DÍAZ, J.; GALVÃO, L. (Orgs.). Saúde sexual e reprodutiva no Brasil. São Paulo: HUCITEC: Population Council, 1999.

DOLTO, F. A causa dos adolescentes. Tradução de Julieta Leite. Rio de Janeiro: Nova Fonteira, 1990.

DOMENACH, J. M. La violência. In: UNESCO (Org.) La violência y us causas. Paris: Unesco, 1981. 
DUBET, F. Sociologia da experiência. Lisboa: Instituo Piaget; 1996.

DUBET, F. Sociologie de l’ experérience. Paris: Editions du Seuil, 1994.

ELIAS, N. O processo civilizatório. Rio de Janeiro: Jorge Zahar, 1993.

Epidat 3.1. Versão de janeiro 2006. Santiago de Compostela: Diréccion Xeral de Saúde Pública. Conselleria de Sanidade. Xunta de Galicia; OPS/OMS, 2006. Programa de computador.

FEFFERMANN, M. Vidas arriscadas: o cotidiano dos jovens trabalhadores do tráfico. Rio de Janeiro: Vozes, 2006.

FERNADEZ, A. R. M; LICO, F. M. C. Nossa história, nossa trajetória. In:

FERNANDEZ, J. C. A.; MENDES, R. Gestão local e políticas públicas para a qualidade de vida. In: FERNANDEZ, J. C. A.; MENDES, R. (Orgs). Promoção da saúde e gestão local. Paulo: Aderaldo \& Rothschild: Cepedoc, 2007.

FORACCHI, M. M. A participação social dos excluídos. São Paulo: Hucitec, 1982.

FREEMAN, LINTON C. : Centrality in social networks conceptual clarification in social networks. Lauzanne: Elsevier Sequoia, 1978/79. v. 1, p. 215-239.

FREITAS, M.V. Jovens no ensino supletivo: diversidade de experiências. 1995. Dissertação (Mestrado) - Faculdade de Educação, Universidade de São Paulo, São Paulo.

FREUD, S. Por que a guerra? In: Obras completas. Rio de Janeiro: Imago, 1980. v.22.

FUNDAÇÃO IBGE. Censo demográfico 2000. Rio de Janeiro, 2000.

FUNDAÇÃO SEADE. Perfil municipal. São Paulo, 2002.

FUNDAÇÃO SEADE. Pesquisa de condição de vida no Estado de São Paulo: situação socioeconômica da população paulista. São Paulo, 2002.

GALVÃO, I. Manifestações e perspectiva: a visão do jovem sobre a violência. In: WESTPHAL, M. F (Org.). Violência e criança. São Paulo: EDUSP, 2002.

GEERTZ,C.A interpretação da cultura.Zahar Ed.,1979

GOMES, J. V. Jovens urbanos pobres: anotações sobre escolaridade e emprego.

Revista brasileira de Educação, Campinas, n.5-6, 1997. Disponível em: < 
http://www.anped.org.br/rbe/rbedigital/RBDE05_6/RBDE05_6_07_JERUSA_VIEIR A_GOMES.pdf >. Acesso em: 21 abr. 2008.

GOMES, R. A. Violência enquanto agravo à saúde de meninas que vivem na rua. Cadernos de Saúde Pública, Rio de Janeiro, v. 10, supl. 1, p. 156-167, 1994.

GONÇALVES, H. S. Juventude brasileira entre a tradição e a modernidade. Tempo Social - Revista de Sociologia da USP, v. 17, n. 2, p. 207-219, nov. 2005. Disponível em: < http://www.scielo.br/pdf/ts/v17n2/a09v17n2.pdf >. Acesso em: 21 abr. 2008.

GUERRA, V. N. A. Violência física doméstica contra crianças e adolescentes e a imprensa: do silêncio à comunicação. 1996. Tese (Doutorado) - Pontifícia Universidade Católica de São Paulo, São Paulo.

GUIMARÃES, E. Escola, galeras e narcotráfico: novos padrões de relacionamento entre a escola pública de $1 \circ$ grau e o meio urbano na cidade do Rio de Janeiro. In: REUNIÃO DA ANPED, 19., 1996, Caxambu. Anais... São Paulo: ANPED, 1996. p. 121-137.

GUIMARÃES, R. M. O futuro não será de caos e miséria: fortalecendo uma cultura de paz. Porto Alegre: ONG Educadores para a Paz, 2005. Disponível em: < http://www.educapaz.org.br/index2.php?option=com_content\&do_pdf=1\&id=48>. Acesso em 12 out. 2005.

HANCOCK, T. From public health in the 1980's to healthy Toronto 2000. In: EVERS, A.; FARRANT, W.; TROJAN, A. (Orgs.). Healthy public policy at local level. Toronto: Campus Verlag, 1993.

HOBSBAWM, E. Era dos extremos: o breve século XX: 1914 -1991. São Paulo: Companhia das Letras, 1995.

IBGE - Instituto Brasileiro de Geografia e Estatística. Pesquisa Nacional por Amostra de Domicílios - PNAD 2007. Brasília, 2007. Disponível em: $<$ http://www.ibge.gov.br/home/estatistica/populacao/trabalhoerendimento/pnad2007/ default.shtm>. Acesso em: 22 jan. 2009.

INSTITUTO CIDADANIA. Projeto juventude: documento de conclusão. São Paulo, 2004.

INSTITUTO SOU DA PAZ; Secretaria Especial para Participação e Parceria da Prefeitura da Cidade de São Paulo. Projeto São Paulo em paz: plano local de prevenção da violência e promoção da convivência distrito Grajaú. São Paulo, 2007.

JACOBI, P. R. A gestão participativa de bacias hidrográficas no Brasil e os desafios do fortalecimento de espaços públicos colegiados. In: COELHO, V. S. P; NOBRE, M. (Orgs). Participação e deliberação: teoria democrática e experiências institucionais no Brasil contemporâneo. São Paulo: Ed. 34 Letras, 2004. p. 270-289. 
JUNQUEIRA, L. A. P; INOJOSA, R. Intersetorialidade, transetorialidade e reses sociais em saúde. Revista Brasileira de Administração Pública, Rio de Janeiro, v. 34, n. 6, p. 35-45, 2000.

KOGA, D. Medidas de cidades: entre territórios de vida e territórios vividos. São Paulo: Cortez, 2003.

KRUG, E. G. Et al. (Eds). Relatório Mundial sobre violência e saúde. [World report on violence and health]. Geneva: World Health Organization, 2002.

LABONTE, R. Health promotion and empowerment: practice frameworks. Toronto: University of Toronto, Centre for Health Promotion, 1996.

LAVALLE, A.G.; CASTELLO, G.; BICHIR, R. M. Os bastidores da sociedade civil: protagonismos, redes e afinidades no seio das organizações civis. São Paulo: CEBRAP, 2006.

LEFÉVRE, F.; LEFÉVRE, A. M. C. Discurso do sujeito coletivo: um novo enfoque em pesquisa qualitativa (desdobramentos). Caxias do Sul, RS: EDUCS, 2003 .

LEFÈVRE, F.; LEFÉVRE, A. M. C.; TEIXEIRA, J. J. V. (Orgs) . O Discurso do Sujeito Coletivo: uma abordagem metodológica em pesquisa qualitativa. Caxias do Sul, RS: EDUCS, 2000.

LEVISKY, D. L (Org.). Adolescência e violência: ações comunitárias na prevenção: conhecendo, articulando, integrando e multiplicando. São Paulo: Casa do Psicólogo: Hebraica, 2001.

LEVISKY, D. L (Org.). Adolescência pelos caminhos da violência. São Paulo: Casa do Psicólogo, 1998.

LEVISKY, D. L. Adolescência e violência: as conseqüências da realidade brasileira. Porto Alegre: Artes Médicas, 1997.

LÜDKE, M.; MEDA, A. Pesquisa em educação: abordagens qualitativas. São Paulo: EPU, 1986.

MADEIRA, F. Os jovens e as mudanças estruturais na década de 70: questionando pressupostos e sugerindo pistas. Cadernos de pesquisa, São Paulo, n.58, 1986.

MADEIRA, F. R.; RODRIGUES, E. M. Recado dos jovens: mais qualificação. In: BERQUÓ, E (Org). Jovens acontecendo nas trilhas das políticas públicas. Brasília: CNPq, 1998. p. 427-498. 
MAGALHÃES, R. S. O discurso do protagonismo juvenil. 2006. Tese (Doutorado em Sociologia) - Faculdade de Filosofia, Letras e Ciências Humanas, Universidade de São Paulo, São Paulo.

MANN, J.; TARANTOLA, D. (Eds.). AIDS in the world II. New York: Oxford: University Press, 1996.

MAPINFO Professional 7.0. Copyright 1985 - 2002. Troy (NY): Mapinfo Corporation , 2002.

MARTELETO, R. M. Análise das redes sociais: aplicação nos estudos de transferência da informação. Ciência e Informação, Brasília, v. 30, n. 1, p.71-81, 2001.

MEAD, G.H. L'Esprit, le soi et la société. Paris: PUF, 1963.

MECCA, A.; SMELSER, N. J.; VASCONCELLOS, J. The social importance of self-esteem. Berkeley: University of California Press, 1989.

MELLO JORGE, M. H. P.; GOTLIEB, S. L. D.; LAURENTI, R. Crianças, adolescentes e jovens no Brasil no fim do século. In: WESTPHAL, M. F. (Org). Violência e criança. São Paulo: Editora EDUSP, 2002.

MELLO, S. L. A violência urbana e a exclusão dos jovens. In: SAWAIA, B. As artimanhas da exclusão: análise psicossocial e ética da desigualdade social. Petrópolis: Vozes, 1999.

MELLO, S. L. A violência urbana. In: SAWAIA, B. (Org.). As artimanhas da exclusão: análise psicossocial e ética da desigualdade social. Petrópolis: Vozes, 1999.

MELUCCI, A. A invenção do presente: movimentos sociais nas sociedades complexas. Rio de Janeiro: Vozes, 2001.

MELUCCI, A. Il gioco dell'io: il cambiamento di sè in una società globale. [S.1.]: Editora Feltrinelli, 1992.

MELUCCI, A. O jogo do eu: a mudança de si mesmo na sociedade global. São Leopoldo: Editora Unisinos, 2004.

MENDES, R.; DONATO, A. F.. Território: espaço social de construção de identidades e de políticas. SANARE, Revista de Políticas Públicas, v. 4, n.1,p.3538, 2003.

MICHAUD, Y . La violence: que sais-je. Paris: PUF, 2002. 
MILANI, F. Saúde e paz: o desafio da construção de políticas públicas integradas. Divulgação em Saúde para Debate, Rio de Janeiro, n. 33, p. 52-61, 2005.

MINAYO, M. C. S . Violência na adolescência: um problema de saúde pública. Cadernos de Saúde Pública, Rio de Janeiro, v. 6, n. 3, p. 278-292, 1990.

MINAYO, M. C. S. (Org.). Avaliação por triangulação de métodos: abordagem de programas sociais. Rio de Janeiro: Editora Fiocruz, 2005.

MINAYO, M. C. S. Abordagem antropológica para avaliação de políticas sociais. Revista de Saúde Pública, São Paulo, v. 25, n. 3, p. 233-8, 1998.

MINAYO, M. C. S. et al. Juventude, violência e cidadania. Rio de Janeiro: Garamond, 1999.

MINAYO, M. C. S. O desafio do conhecimento. São Paulo: Hucitec, 2004.

MINAYO, M. C. S. O desafio do conhecimento: pesquisa qualitativa em saúde. São Paulo: Editora Hucitec, 2006.

MINAYO, M. C. S. O significado social e para a saúde da violência contra crianças e adolescentes. In: WESTPHAL, M F (Org). Violência e criança. São Paulo: Editora EDUSP, 2002.

MINAYO, M. C. S. Violência e saúde. Rio de Janeiro: Editora Fiocruz, 2006.

MINAYO, M. C. S.; ASSIS, S. G. Saúde e violência na infância e adolescência. Jornal de Pediatria, Rio de Janeiro, v. 70, n. 5, p. 263-266, 1994.

MINAYO, M. C. S.; DESLANDES, S. F. A complexidade das relações entre droga, álcool e violência. Cadernos de Saúde Pública, Rio de Janeiro, v. 14, n. 1, p. 35-42, 1998.

MINAYO, M. C. S.; SOUZA E. R. (Orgs). Violência sob o olhar da saúde: infrapolítica da contemporaneidade brasileira. Rio de Janeiro: FIOCRUZ, 2003.

MINISTÉRIO DA SAÚDE. Portaria MS/GM n.737, de 16 de maio de 2001. Política Nacional de Redução da Morbimortalidade por Acidentes e Violências. Diário Oficial da União, Brasília, DF, 18 maio 2001.

MINISTÉRIO DA SAÚDE. Portaria nº 737 MS/GM, de 16 jul. 2001. Regulamenta a Política Nacional de Redução da Morbimortalidade por Acidentes e Violências. Brasília, DF; 2001. 
MINISTÉRIO DA SAÚDE. Secretaria de Políticas de Saúde. Coordenação da Saúde da Criança e do Adolescente. Saúde e desenvolvimento da juventude brasileira: construindo uma agenda nacional. Brasília (DF): Ministério da Saúde, 2000.

MUCCHIELLI, A . Dictionnaire des méthodes qualitatives in sciences et sociales. Paris: Armand Colin: Masson, 1996.

NOVAES, R. Juventude, exclusão e inclusão social: aspectos e controvérsias de um debate em curso.In : FREITAS, M. V., PAPA, F. C, (Orgs). Políticas públicas: juventude em pauta. São Paulo: Cortez: Ação Educativa: Fundação Friedrich Ebert, 2003.

OIT - Organização Internacional do Trabalho. Relatório da Organização Internacional do Trabalho, 2006.

ONU - Organisation des Nations Unies pour l'éducation, la science et la culture. Manuel de la Conférence générale lors de sa 31e session. Paris, 2001. Disponível em: <http://unesdoc.unesco.org/images/0012/001255/125590f.pdf\#constituition. > . Acesso em: 21 abr. 2008.

ONU - Organização das Nações Unidas. Constituição da Organização das Nações Unidas para a Educação, Ciência e Cultura (Unesco). Londres, 16 nov. 1945.

ONU - Organização das Nações Unidas. Convenção das Nações Unidas sobre os Direitos da Criança. New York, 1989.

ONU - Organização das Nações Unidas. Declaração do Milênio. New York, 2000.

ONU - Organização das Nações Unidas. Programa das Nações Unidas para a Juventude. Departamento de Assuntos Econômicos e Sociais (DESA). World Youth Report 2005: young people today and in 2015. 2005.

ONU - Organizações das Nações Unidas. Declaração Universal dos Direitos Humanos. New York, 1948.

ORGANIZAÇÃO MUNDIAL DA SAÚDE. Relatório Mundial sobre violência e saúde. [World report on violence and health]. Genebra: OMS, 2002.

ORGANIZAÇÃO PANAMERICANA DE LA SALUD. Planificación local participativa: metodologias para la promoción de la salud em Ameérica y el Caribe. Washington (DC), 1999.

ORGANIZAÇÃO PANAMERICANA DE SAÚDE. O marco integral da saúde do adolescente e seu cuidado. Washington: OPS, 1990. (mimeo).

ORGANIZAÇÃO PANAMERICANA DE SAÚDE. Violência y salud. Washington, 1993. (Documento CD37/19). 
PAIS, J. M. Culturas juvenis. Liboa: Imprensa Nacional, 2003.

PAIS, J. M. Culturas juvenis. Lisboa: Imprensa Nacional Casa da Moeda, 1993.

PATTON, M. Q. Qualitative evaluation methods. London: Beverly Hills: Sage Publications, 1987.

PERALVA, A . Violência e democracia: o paradoxo brasileiro. São Paulo: Paz e Terra, 2000.

PERALVA, A. Des collegiens et de la violence . In: CHARLOT, B.; EMIN, J. C. (Coord.). Violences à l' école: état des lieux. Paris: Armand Colin, 1997.

PERALVA, A. O jovem como modelo cultural. Revista Brasileira de Educação, São Paulo, n. 5/6, p. 15-24, 1997.

PEREIRA, J. C. R. Análise de dados qualitativos para as ciências da saúde, humanas e sociais. 3. ed. São Paulo: Edusp, 2004.

PEREIRA, J. C. R. Análise de dados qualitativos: estratégias metodológicas para as ciências da saúde, humanas e sociais. 3. ed. São Paulo: Edusp, 2001.

PERES, M .F.T.; CARDIA, N.; SANTOS, P. C. Homicídios de crianças e jovens no Brasil: 1980-2002. São Paulo: Núcleo de Estudos da Violência / USP, 2006. p.17-40.

PERES, M. F.; RUOTTI, C.; VICENTIN, D. Violência: definição, tipos e representações. In: WESTPHAL, M. F.; BIDYLOWSKI, C. (Orgs). Violência e Juventude, 2009. No prelo.

PMSP- PREFEITURA DO MUNICÍPIO DE SÃO PAULO. História de M Boi Mirim. Disponível em:

$<$ http://portal.prefeitura.sp.gov.br/subprefeituras/spmb/dados/historico/0001>. Acesso em: 13 set. 2008.

QUALIQUANTSOFT. SPI. Versão 1.3c. São Paulo: Sales \& Paschoal Informática, s.d.

SACARDO, D.P.; GONÇALVES, C. C. M. Território: potencialidades na construção de sujeitos. In: FERNANDEZ, J. C.A.; MENDES, R. (Orgs). Promoção da saúde e gestão local. São Paulo: Aderaldo \& Rothschild: Cepedoc, 2007.

SANTOS, B. R. A emergência da concepção moderna de infância e adolescência: mapeamento, documentação e reflexão sobre as principais teorias. 1996. Dissertação (Mestrado em Ciências Sociais/Antropologia) - Pontifícia Universidade Católica, São Paulo. 
SANTOS, M. O espaço do cidadão. São Paulo: Nobel, 1987.

SANTOS, M. Por uma outra globalização: do pensamento único à consciência universal. 12. ed. Rio de Janeiro: Record, 2005.

SANTOS, B.S.A.A construçãomulticultural da igualdade e da diferença,. In: CONFERÊNCIA NO VII CONGRESSO BRASILEIRO DE SOCIOLOGIA. Instituto de Filosofia e Ciências Sociais da Universidade Federal, RJ. 0406/09/1995, p.1-56, 1995.

SÃO PAULO (Município). Secretaria Municipal de Planejament; Departamento de Estatística e Produção de Informação. Olhar São Paulo: violência e criminalidade. São Paulo: SEMPLA, 2008.

SÃO PAULO. Prefeitura Municipal. Prefeitura lança operação de defesa das águas. São Paulo, [s.d.]. Disponível em: http://www6.prefeitura.sp.gov.br/noticias/ars/sppa/2007/04/0002. Acesso em: 15 out. 2008.

SÃO PAULO. Prefeitura Municipal. Secretaria Municipal de Saúde. Painel de monitoramento das condições de vida e saúde e da situação dos serviços de saúde. São Paulo, 2002.

SARTI, C. A. A família como espelho: um estudo sobre a moral dos pobres. 4. ed. São Paulo: Cortez, 2007.

SCHALLER, J. J. Construir um viver junto na democracia renovada. Educação e Pesquisa, São Paulo, v. 28, n. 2, p. 145-161, jul./dez. 2002.

SCHILLING, F. A multidimensionalidade da violência In: CARVALHO, J. S. (Org.). In: EDUCAÇÃO, cidadania e direitos humanos. Petrópolis, RJ: Vozes, 2004.

SCHILLING, F. A sociedade da insegurança e a violência na escola. São Paulo: Moderna, 2004. (Coleção cotidiano escolar).

SCHOR, D et al. Medidas de rede e apoio social no estudo pró-saúde: pré-testes e estudo piloto. Cadernos de Saúde Pública, Rio de Janeiro, v. 17, n. 4, p. 887-896, 2001.

SCHOR, N. et. al. (Orgs). Cadernos Juventude, Saúde e Desenvolvimento. Brasília: Ministério da Saúde. Secretaria de Políticas de Saúde, 1999.

SECRETARIA MUNICIPAL DA SAÚDE DE SÃO PAULO. Coordenadoria Regional de Saúde Sul. Painel de monitoramento. São Paulo, 2005.

SECRETARIA MUNICIPAL DA SAÚDE. Pro-AIM: mortalidade no município de São Paulo. Disponível em: 
$<$ http://ww2.prefeitura.sp.gov.br//cgi/deftohtm.exe?secretarias/saude/TABNET/SIM/ obito.def >. Acesso em: 2 abr. 2007.

SILVA, C. S. A. Solta a voz: saúde e risco em escolares. Rio de Janeiro: Prefeitura da Cidade do Rio de Janeiro, Secretaria Municipal de Saúde, 2002.

SOARES, L. E. Prefácio. In: MINAYO, M. C. S, SOUZA, E. R. (Orgs.) Violência sob o olhar da saúde: a infrapolítica da contemporaneidade brasileira. Rio de Janeiro: Fiocruz, 2003.

SOUZA, C. Z.V.G. Juventude e contemporaneidade: possibilidades e limites.Última Década, Valparaíso, n. 20, p. 47-69, jun. 2004.

SOUZA, E. R. Análise temporal da mortalidade por causas externas no Brasil: década de 90. In: MINAYO, M. C. S. et al. Violência sob o olhar da saúde: infrapolítica da contemporaneidade brasileira. Rio de Janeiro: Editora Fiocruz, 2003.

SOUZA, E. R. de (Org). Bases conceituais e históricas da violência e setor saúde. In: Curso impactos da violência na saúde. Rio de Janeiro: EAD/ENSP, 2007. (Unidade I).

SOUZA, E. R. Masculinidade e violência no Brasil: contribuições para a reflexão no campo da saúde. Ciência \& Saúde Coletiva, Rio de Janeiro, v. 10, n. 1, p. 59-70, 2005 .

SOUZA, E. R. Quando viver é o grande risco-aventura. Cadernos de Saúde Pública, Rio de Janeiro, v. 17, n. 6, p. 1277-1292, 2001.

SOUZA, E. R. S et al. Análise temporal da mortalidade por causas externas no BRASIL: décadas de 80 e 90. In : MINAYO, M. C. S., SOUZA, E. R. (Orgs.). Violência sob o olhar da saúde: a infrapolítica da contemporaneidade brasileira. Rio de Janeiro: Fiocruz, 2003.

SPHINX plus 2. Version 4.0. Rio de Janeiro: Sphinx do Brasil., [s.d.].

SPINK, M. J.; MEDRADO, B. Produção de sentidos no cotidiano: uma abordagem teórico-metodológica para análise das práticas discursivas. In: SPINK, M. J. (Org.).

Práticas discursivas e produção de sentidos no cotidiano: aproximações teóricas e metodológicas. São Paulo: Cortez, 1999.

SPÓSITO, M. Trajetórias na constituição de políticas públicas de juventude no Brasil. In: FREITAS, M. V.; PAPA, F. C. (Orgs). Políticas públicas: juventude em pauta. São Paulo: Cortez: Ação Educativa Assessoria, Pesquisa e Informação: Fundação Frieddrich Ebert, 2003.

SPÓSITO, M. P. A instituição escolar e a violência. In: CARVALHO, J. S. (org.). Educação, cidadania e direitos humanos. Petrópolis, RJ : Vozes, 2004. 
SPÓSITO, M. P. Algumas hipóteses sobre as relações entre movimentos sociais, juventude e educação. Revista Brasileira de Educação, São Paulo, n. 13, p. 73-94, 2000 .

TAQUETTE, S.et al. Mulher adolescente/jovem em situação de violência. Brasília:Secretaria Especial de Políticas para as Mulheres,2007.

TOURAINE, A.Um novo paradigma: para compreender o mundo de hoje. Tradução de Titton, A. G. 3. ed. Petrópolis, RJ: Vozes, 2007.

UNESCO - Organização das Nações Unidas para a Educação, Ciência e Cultura; LLECE - Laboratório Latinoamericano de Evaluación de la Calidad de la Educatión. Estudio cualitativo de escuelas com resultados destacables em siete países latinoamericanos. Santiago de Chile: UNESCO, 2002. UNICEF. Relatório da situação da infância e adolescência brasileiras: diversidade e equidade. Brasília: UNICEF, 2003.

VENTURA, M. Sexualidade e reprodução na adolescência: uma questão de direitos. In: ADORNO, R. C. F.; ALVARENGA, A. T.; VASCONCELLOS, M. P. C. (Orgs). Jovens, trajetórias, masculinidades e direitos. São Paulo: Fapesp: Editora da Universidade de São Paulo, 2005.

WAISELFISZ, J. J. Mapa da violência 2006: os jovens do Brasil. 1. ed. Brasília:

WALLERSTEIN, N. Empowerment education applied to youth. In: MATTIELLA, A. C. (Ed.). The multicultural challenge in heath education. California: ETR Associates Publishers, 1994. p.153-76.

WESTPHAL, M. F (Org.) Violência e criança. São Paulo: EDUSP, 2002.

WESTPHAL, M. F. et al. (Coord.) A proposta de municípios saudáveis (OMS) em Bertioga: contribuição os conhecimentos técnicos, científicos, interdisciplinares e das representações sociais. 2000. Projeto Temático de Pesquisa encaminhado à FAPESP, São Paulo.

WESTPHAL, M. F.; CHIESA, A. M. The integration of quali-quantitative techniques in health promotion research: experiences developed in Brazil. In: CONFERENCE ON HEALTH PROMOTION AND HEALTH EDUCATION, 17. 2001, Paris. Book of Abstracts... Paris, 2001.

WESTPHAL, M. F.; PAIS, T. D. (Ogs). Capela saudável: gestão de políticas públicas integradas participativas. São Paulo: Editora da Universidade de São Paulo, 2006. 
WESTPHAL, M. F.; ZIONI, F. O enfoque dos determinante sociais de saúde sob o ponto de vista da teoria social. Saúde e Sociedade, São Paulo, v. 16. n. 3, p. 26-34, 2007.

WESTPHAL, M. F; CHIESA, A. M. A erradicação do trabalho infantil: a contribuição da metodologia de pesquisa. In: WESTPHAL, M. F. (Coord.);

WIEVIORKA, M. Em que mundo viveremos? São Paulo: Perspectiva, 2006.

WORLD HEALTH ASSEMBLY . Prevention of violence: public health priority. (Resolution no. WHA 49.25). Geneva: WHO, 1996. 
ANEXOS 
Anexo 2

UNIVERSIDADE DE SÃO PAULO

FACULDADE DE SAÚDE PÚBLICA

COMITÊ DE ÉTICA EM PESQUISA - COEP/FSP

Av. Dr. Arnaldo 715 - 01246-904-São Paulo-SP - Tel. (55-11) 3061-7779 e-mail:coep@ fsp.usp.br

\section{TERMO DE CONSENTIMENTO LIVRE E ESCLARECIDO}

Fase 3 Pesquisa com profissionais de saúde e educação, entidades de apoio ao desenvolvimento do jovem.

\section{I - DADOS SOBRE A PESQUISA}

Título do Protocolo de Pesquisa: Juventude, Violência e Ação Coletiva Pesquisador:. Fátima Madalena de Campos Lico

Documento de Identidade $N^{\circ}: 7.770 .329$ - 7 Sexo: ( ) M (X ) F

Cargo/Função: estudante pós-graduação nível doutorado

Departamento: Prática de Saúde Pública da Faculdade de Saúde Pública da Universidade de São Paulo

Avaliação de Risco da Pesquisa
( ) Sem Risco
( X ) Risco Mínimo
( ) Risco Médio
( ) Risco Baixo
( ) Risco Maior

Duração da Pesquisa: 2 anos e seis meses

II - REGISTRO DAS EXPLICAÇÕES DO PESQUISADOR AO SUJEITO DA PESQUISA OU SEU REPRESENTANTE LEGAL SOBRE A PESQUISA. 


\section{(1) \\ UNIVERSIDADE DE SÃO PAULO \\ FACULDADE DE SAÚDE PÚBLICA}

\section{COMITÊ DE ÉTICA EM PESQUISA - COEP/FSP \\ Av. Dr. Arnaldo 715 - 01246-904-São Paulo-SP - Tel. (55-11) 3061-7779 e-mail:coep@ fsp.usp.br}

Você está sendo convidado (a) a participar de uma pesquisa, que tem por finalidade contribuir para desenvolvimento de políticas públicas para a juventude nas regiões dos Distritos Administrativos do Grajaú e Jardim Ângela visando enfrentamento da violência e construção de uma cultura de paz nas duas regiões de estudo.

Sua participação nos ajudarão a conhecer a região, a qualidade de vida dos jovens, os projetos de saúde e apoio ao desenvolvimento dos jovens e, também, como vivem os jovens na região. Os resultados desse estudo serão fornecidos às Subprefeituras da Capela do Socorro e M’Boi Mirim, à Coordenadoria de Saúde da Região Sul, Secretaria Municipal da Saúde e outras entidades participantes da pesquisa com a finalidade de contribuir para o implantação de políticas públicas para a juventude das regiões.

Caso você concorde em participar será necessário fazer algumas perguntas, para conhecermos a sua unidade, a região, os projetos de apoio ao desenvolvimento dos jovens existentes na região, sua opinião sobre a juventude, sobre os problemas de saúde dos jovens, projetos existentes para melhoria das condições vida e de saúde, para enfrentamento da violência, atividades e espaços de lazer para os jovens na região. As perguntas serão feitas por meio de um formulário individual. A sua participação não implicará em despesas para você e nem riscos para a sua saúde ou de sua família, o senhor (a) apenas terá que dedicar aproximadamente 1 hora do seu tempo para responder a um questionário

Prometemos que logo que terminar o trabalho vamos retornar a você os resultados da pesquisa através de seminário na região e de relatório para entidades, órgãos públicos, e setores envolvidos no estudo. 


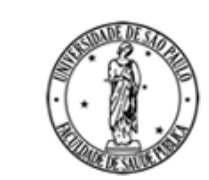

UNIVERSIDADE DE SÃO PAULO

FACULDADE DE SAÚDE PÚBLICA

COMITÊ DE ÉTICA EM PESQUISA - COEP/FSP

Av. Dr. Arnaldo 715 - 01246-904-São Paulo-SP - Tel. (55-11) 3061-7779 e-mail:coep@fsp.usp.br

III - ESCLARECIMENTOS DADOS PELO PESQUISADOR SOBRE GARANTIAS DO SUJEITO DA PESQUISA

O seu nome não aparecerá em qualquer momento do estudo, pois você será identificado (a) com um número.Garantimos que as informações que nos der serão mantidas em sigilo profissional e não serão divulgadas em sua unidade de trabalho, somente serão utilizadas para finalidade da pesquisa. Você poderá ter todas as informações que quiser e poderá retirar o seu consentimento a qualquer momento.

A sua participação é livre e voluntária, sendo que poderá desistir de participar da pesquisa a qualquer momento, sem qualquer prejuízo nas relações de trabalho.Qualquer dúvida que você tiver poderá procurar, a qualquer momento, a coordenadora da pesquisa Sra Fátima Madalena de Campos Lico pelo telefone 30854760 e o Comitê de Ética e Pesquisa da Faculdade de Saúde Pública pelo telefone 30617779 .

Agradeço desde já a sua colaboração.

IV - INFORMAÇÕES DE NOMES, ENDEREÇOS E TELEFONES DOS RESPONSÁVEIS PELO ACOMPANHAMENTO DA PESQUISA PARA CONTATO.

Nome: Fátima Madalena de Campos Lico. Telefone: 30854760 /96315137

Endereço: Av. Dr Arnaldo No. 715

Bairro: Cerqueira César

Cidade: São Paulo CEP: 01246-904

Nome: Márcia Faria Westphal

Endereço: Av. Dr Arnaldo No. 715

Bairro: Cerqueira César

Telefone: 30617766

Cidade: São Paulo. CEP: 01246-904 


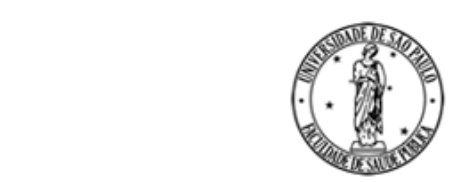

UNIVERSIDADE DE SÃO PAULO

FACULDADE DE SAÚDE PÚBLICA

\section{COMITÊ DE ÉTICA EM PESQUISA - COEP/FSP}

Av. Dr. Arnaldo 715 - 01246-904-São Paulo-SP - Tel. (55-11) 3061-7779 e-mail:coep@fsp.usp.br

\section{V - CONSENTIMENTO PÓS-ESCLARECIDO}

Declaro que, após convenientemente esclarecido pelo pesquisador e ter entendido o que me foi explicado, consinto em participar do presente Protocolo de Pesquisa.

São Paulo, de de 
Anexo 5

UNIVERSIDADE DE SÃO PAULO

FACULDADE DE SAÚDE PÚBLICA

COMITÊ DE ÉTICA EM PESQUISA - COEP/FSP

Av. Dr. Arnaldo 715 - 01246-904-São Paulo-SP - Tel. (55-11) 3061-7779 e-mail:coep@ fsp.usp.br

\section{TERMO DE CONSENTIMENTO LIVRE E ESCLARECIDO}

Fase 2 Pesquisa domiciliar (pais ou responsável legal do jovem das famílias cadastradas no Programa Saúde da Família)

I - DADOS SOBRE A PESQUISA

Título do Protocolo de Pesquisa: Juventude, Violência e Ação Coletiva

Pesquisador:. Fátima Madalena de Campos Lico

Documento de Identidade $\mathrm{N}^{\circ}: 7.770 .329$ - 7 Sexo: ( ) $\mathrm{M} \quad(\mathrm{X}$ ) F

Cargo/Função: estudante pós-graduação nível doutorado

Departamento: Prática de Saúde Pública da Faculdade de Saúde Pública da Universidade de São Paulo

Avaliação de Risco da Pesquisa

$\begin{array}{lll}\text { ( } \quad \text { ) Sem Risco } & \text { ( X ) Risco Mínimo } & \text { ( } \quad \text { ) Risco Médio } \\ \text { ( } \quad \text { ) Risco Baixo } & \text { ( } \quad \text { ) Risco Maior }\end{array}$

Duração da Pesquisa: 2 anos e seis meses

II - REGISTRO DAS EXPLICAÇÕES DO PESQUISADOR AO SUJEITO DA PESQUISA OU SEU REPRESENTANTE LEGAL SOBRE A PESQUISA. 


\section{(1) \\ UNIVERSIDADE DE SÃO PAULO \\ FACULDADE DE SAÚDE PÚBLICA}

\section{COMITÊ DE ÉTICA EM PESQUISA - COEP/FSP \\ Av. Dr. Arnaldo 715 - 01246-904-São Paulo-SP - Tel. (55-11) 3061-7779 e-mail:coep@ fsp.usp.br}

Você está sendo convidado a participar de um estudo que tem a finalidade de contribuir para desenvolvimento de políticas públicas para a juventude nas regiões dos Distritos Administrativos do Grajaú e Jardim Ângela, visando o enfrentamento da violência e a construção de uma cultura de paz nas duas regiões de estudo.

A sua participação nos ajudará a conhecer a região, a qualidade de vida dos jovens e também, como vivem os jovens na região. Os resultados desse estudo serão fornecidos às Subprefeituras da Capela do Socorro e M'Boi Mirim, à Coordenadoria de Saúde e Secretaria Municipal da Saúde e outras entidades participantes da pesquisa com a finalidade de contribuir para o implantação de políticas públicas para a juventude local.

Caso você concorde em participar, será solicitado a responder algumas perguntas para conhecermos as condições de vida dos jovens tais como: trabalho, renda, escolaridade, atividades e recursos existentes no bairro para os jovens e também sua opinião sobre os bairro. As perguntas serão feitas por meio de um formulário. A sua participação não implicará em despesas para você e nem riscos para a sua saúde ou de sua família, o senhor (a) apenas terá que dedicar aproximadamente 1 hora do seu tempo para responder a um questionário.

Prometemos que logo que terminar o trabalho vamos retornar a você os resultados da pesquisa através de seminário na região e de relatório para entidades, órgãos públicos, e setores envolvidos no estudo. 


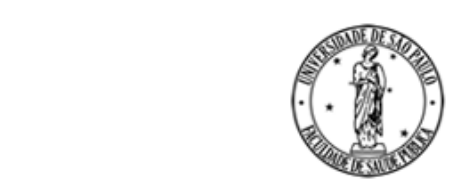

UNIVERSIDADE DE SÃO PAULO

FACULDADE DE SAÚDE PÚBLICA

COMITÊ DE ÉTICA EM PESQUISA - COEP/FSP

Av. Dr. Arnaldo 715 - 01246-904-São Paulo-SP - Tel. (55-11) 3061-7779 e-mail:coep@fsp.usp.br

III - ESCLARECIMENTOS DADOS PELO PESQUISADOR SOBRE GARANTIAS DO SUJEITO DA PESQUISA

O seu nome não aparecerá em qualquer momento do estudo, pois você será identificado (a) com um número.Garantimos que as informações que nos der serão mantidas em sigilo profissional e somente serão utilizadas para finalidade da pesquisa. Você poderá ter todas as informações que quiser e poderá retirar o seu consentimento a qualquer momento.

A sua participação é livre e voluntária, sendo que poderá desistir de participar da pesquisa a qualquer momento, sem qualquer prejuízo.Qualquer dúvida que você tiver poderá procurar, a qualquer momento, a coordenadora da pesquisa Sra Fátima Madalena de Campos Lico pelo telefone 30854760 e o Comitê de Ética e Pesquisa da Faculdade de Saúde Pública pelo telefone 30617779.

Agradeço desde já a sua colaboração. 


\section{(1)}

UNIVERSIDADE DE SÃO PAULO

FACULDADE DE SAÚDE PÚBLICA

COMITÊ DE ÉTICA EM PESQUISA - COEP/FSP

Av. Dr. Arnaldo 715 - 01246-904-São Paulo-SP - Tel. (55-11) 3061-7779 e-mail:coep@fsp.usp.br

IV - INFORMAÇÕES DE NOMES, ENDEREÇOS E TELEFONES DOS RESPONSÁVEIS PELO ACOMPANHAMENTO DA PESQUISA PARA CONTATO.

Nome: Fátima Madalena de Campos Lico. Telefone: 30854760 /96315137

Endereço: Av. Dr Arnaldo No 715

Bairro: Cerqueira César C Cidade: São Paulo CEP: 01246-904

Nome: Márcia Faria Westphal

Telefone: 30617766

Endereço: Av. Dr Arnaldo No 715

Bairro: Cerqueira César

Cidade: São Paulo. CEP: 01246-904

\section{V - CONSENTIMENTO PÓS-ESCLARECIDO}

Declaro que, após convenientemente esclarecido pelo pesquisador e ter entendido o que me foi explicado, consinto em participar do presente Protocolo de Pesquisa.

São Paulo, de de 
Anexo 6

UNIVERSIDADE DE SÃO PAULO

FACULDADE DE SAÚDE PÚBLICA

COMITÊ DE ÉTICA EM PESQUISA - COEP/FSP

Av. Dr. Arnaldo 715 - 01246-904-São Paulo-SP - Tel. (55-11) 3061-7779 e-mail:coep@ fsp.usp.br

\section{TERMO DE RESPONSABILIDADE DO PESQUISADOR}

Fase 2. Para entrevistas com os jovens de 10-19 anos, cadastrados no Programa Saúde da Família..

\section{I - DADOS SOBRE A PESQUISA}

Título do Protocolo de Pesquisa: Juventude, Violência e Ação Coletiva Pesquisador:. Fátima Madalena de Campos Lico

Documento de Identidade $N^{\circ}$ :7.770.329 - 7 Sexo: ( ) M $\quad(X) F$

Cargo/Função: estudante pós-graduação nível doutorado

Departamento: Prática de Saúde Pública da Faculdade de Saúde Pública da Universidade de São Paulo

Avaliação de Risco da Pesquisa

$\begin{array}{lll}\text { ( } \quad \text { ) Sem Risco } & \text { ( X ) Risco Mínimo } & \text { ( } \quad \text { ) Risco Médio } \\ \text { ( } \quad \text { ) Risco Baixo } & \text { ( } \quad \text { ) Risco Maior }\end{array}$

Duração da Pesquisa: 2 anos e seis meses PESQUISA OU SEU REPRESENTANTE LEGAL SOBRE A PESQUISA. 


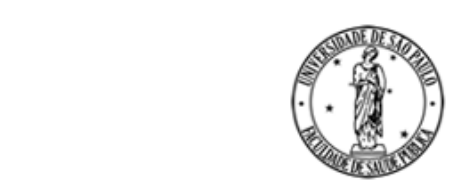

UNIVERSIDADE DE SÃO PAULO

FACULDADE DE SAÚDE PÚBLICA

COMITÊ DE ÉTICA EM PESQUISA - COEP/FSP

Av. Dr. Arnaldo 715 - 01246-904-São Paulo-SP - Tel. (55-11) 3061-7779 e-mail:coep@fsp.usp.br

\section{Prezado (a) Jovem}

Você está sendo convidado a participar de um estudo que tem a finalidade de contribuir para desenvolvimento de políticas públicas para a juventude nas regiões dos Distritos Administrativos do Grajaú e Jardim Ângela, visando o enfrentamento da violência e a construção de uma cultura de paz nas duas regiões de estudo.

A sua participação nos ajudará a conhecer a qualidade de vida dos jovens e também, como vivem os jovens na região. Os resultados desse estudo serão fornecidos às Subprefeituras da Capela do Socorro e M`Boi Mirim, à Coordenadoria de Saúde e Secretaria Municipal da Saúde e outras entidades participantes da pesquisa com a finalidade de contribuir para o implantação de políticas públicas para a juventude local.

Caso você concorde em participar, será solicitado a responder a algumas perguntas, para conhecermos a sua opinião sobre juventude, participação, violência, paz, escola, família e sobre o seu bairro. As perguntas serão feitas por meio de entrevista individual. As respostas serão gravadas em fitas cassete, mas você não será identificado (a). As fitas gravadas serão guardadas por 5 anos pela coordenadora da pesquisa. 


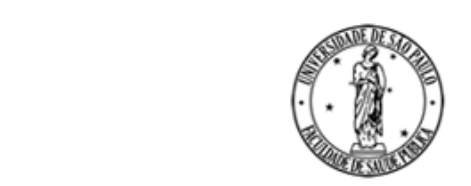

UNIVERSIDADE DE SÃO PAULO

FACULDADE DE SAÚDE PÚBLICA

COMITÊ DE ÉTICA EM PESQUISA - COEP/FSP

Av. Dr. Arnaldo 715 - 01246-904-São Paulo-SP - Tel. (55-11) 3061-7779 e-mail:coep@fsp.usp.br

III - ESClARECIMENTOS DADOS PELO PESQUISADOR SOBRE GARANTIAS DO SUJEITO DA PESQUISA

O seu nome não aparecerá em qualquer momento do estudo, pois, você será identificado (a) com um número.Garantimos que as informações que nos der serão mantidas em sigilo profissional e somente serão utilizadas para finalidade da pesquisa. Você poderá ter todas as informações que quiser e poderá retirar o seu consentimento a qualquer momento.

A sua participação é livre e voluntária, sendo que poderão desistir de participar da pesquisa a qualquer momento, sem qualquer prejuízo. Qualquer dúvida que você tiver poderá procurar, a qualquer momento, a coordenadora da pesquisa Sra Fátima Madalena de Campos Lico pelo telefone 30854760 e o Comitê de Ética e Pesquisa da Faculdade de Saúde Pública pelo telefone 30661779.

A sua participação não implicará em despesa da sua parte ou da sua família, e nem riscos para a sua saúde ou de sua família, apenas implicará na disponibilidade de aproximadamente 30 minutos para você responder o que pensa sobre a juventude, participação, violência, paz, sobre seu bairro, sua escola e sua família.

Prometemos que logo que terminar o trabalho vamos retornar a você os resultados da pesquisa através da realização de um seminário na região e de relatório para entidades, órgãos públicos, e setores envolvidos no estudo.

Agradeço desde já a sua colaboração. 


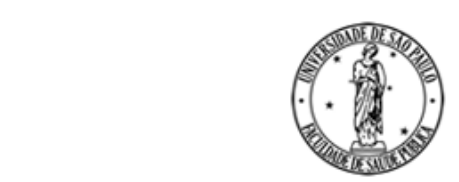

UNIVERSIDADE DE SÃO PAULO

FACULDADE DE SAÚDE PÚBLICA

COMITÊ DE ÉTICA EM PESQUISA - COEP/FSP

Av. Dr. Arnaldo 715 - 01246-904-São Paulo-SP - Tel. (55-11) 3061-7779 e-mail:coep@fsp.usp.br

IV - INFORMAÇÕES DE NOMES, ENDEREÇOS E TELEFONES DOS RESPONSÁVEIS PELO ACOMPANHAMENTO DA PESQUISA PARA CONTATO.

Nome: Fátima Madalena de Campos Lico. Telefone: 30854760 /96315137

Endereço: Av. Dr Arnaldo No 715

Bairro:Cerqueira César. Cidade: São Paulo CEP: 01246-904

Nome: Márcia Faria Westphal

Endereço: Av. Dr Arnaldo No: 715

Bairro:Cerqueira César

Telefone: 30617766

Cidade: São Paulo. CEP: 01246-904

Assinatura do pesquisador (carimbo ou nome legível) 
Anexo 11

UNIVERSIDADE DE SÃO PAULO

FACULDADE DE SAÚDE PÚBLICA

COMITÊ DE ÉTICA EM PESQUISA - COEP/FSP

Av. Dr. Arnaldo 715 - 01246-904-São Paulo-SP - Tel. (55-11) 3061-7779 e-mail:coep@ fsp.usp.br

\section{TERMO DE CONSENTIMENTO LIVRE E ESCLARECIDO}

Fase 2: Para as entrevistas com os jovens de 10-19 anos cadastrados no Programa Saúde da Família.

I - DADOS SOBRE A PESQUISA

Título do Protocolo de Pesquisa: Juventude, Violência e Ação Coletiva Pesquisador:. Fátima Madalena de Campos Lico

Documento de Identidade $N^{\circ}: 7.770 .329$ - 7 Sexo: ( ) $\mathrm{M} \quad$ ( X ) F

Cargo/Função: estudante pós-graduação nível doutorado

Departamento: Prática de Saúde Pública da Faculdade de Saúde Pública da Universidade de São Paulo

Avaliação de Risco da Pesquisa

$\begin{array}{lll}\text { ( } \quad \text { Sem Risco } & \text { ( X ) Risco Mínimo } & \text { ( } \quad \text { ) Risco Médio } \\ \text { ( } \quad \text { ) Risco Baixo } & \text { ( } \quad \text { ) Risco Maior }\end{array}$

Duração da Pesquisa: 2 anos e seis meses

II - REGISTRO DAS EXPLICAÇÕES DO PESQUISADOR AO SUJEITO DA PESQUISA OU SEU REPRESENTANTE LEGAL SOBRE A PESQUISA. 


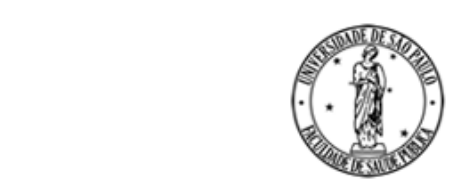

UNIVERSIDADE DE SÃO PAULO

FACULDADE DE SAÚDE PÚBLICA

\section{COMITÊ DE ÉTICA EM PESQUISA - COEP/FSP \\ Av. Dr. Arnaldo 715 - 01246-904-São Paulo-SP - Tel. (55-11) 3061-7779 e-mail:coep@fsp.usp.br}

\section{Prezado (a) Senhor(a)}

Solicitamos sua permissão para que seu (sua) filho (a) participe de um estudo que tem a finalidade de contribuir para desenvolvimento de políticas públicas para a juventude nas regiões dos Distritos Administrativos do Grajaú e Jardim Ângela, visando o enfrentamento da violência e a construção de uma cultura de paz nas duas regiões de estudo.

A participação nos ajudará a conhecer a qualidade de vida dos jovens e também, como vivem os jovens na região. Os resultados desse estudo serão fornecidos às Subprefeituras da Capela do Socorro e M`Boi Mirim, à Coordenadoria de Saúde e Secretaria Municipal da Saúde e outras entidades participantes da pesquisa com a finalidade de contribuir para o implantação de políticas públicas para a juventude local.

Caso você concorde, seu (sua) filho (a) será solicitado a responder a algumas perguntas, para conhecermos a sua opinião sobre juventude, participação, violência, paz, sobre o bairro, a escola e a família. As perguntas serão feitas por meio de entrevista individual. As respostas serão gravadas em fitas cassete, mas ele (ela) não será identificado (a). As fitas gravadas serão guardadas por 5 anos pela coordenadora da pesquisa.

III - ESCLARECIMENTOS DADOS PELO PESQUISADOR SOBRE
GARANTIAS DO SUJEITO DA PESQUISA




\section{(1) \\ UNIVERSIDADE DE SÃO PAULO \\ FACULDADE DE SAÚDE PÚBLICA}

\section{COMITÊ DE ÉTICA EM PESQUISA - COEP/FSP}

\section{Av. Dr. Arnaldo 715 - 01246-904-São Paulo-SP - Tel. (55-11) 3061-7779 e-mail:coep@fsp.usp.br}

O nome do seu filho (a) não aparecerá em qualquer momento do estudo, pois ele (ela)será identificado (a) com um número.Garantimos que as informações que nos der serão mantidas em sigilo profissional e somente serão utilizadas para finalidade da pesquisa. O senhor (a) e o seu filho (filha) poderão ter todas as informações que quiserem e poderão retirar o seu consentimento a qualquer momento.

A participação do seu filho (filha) é livre e voluntária, sendo que poderão desistir de participar da pesquisa a qualquer momento, sem qualquer prejuízo. Qualquer dúvida que você ou seu filho tiverem poderão procurar, a qualquer momento, a coordenadora da pesquisa Sra Fátima Madalena de Campos Lico pelo telefone 30854760 e o Comitê de Ética e Pesquisa da Faculdade de Saúde Pública pelo telefone 30617779 .

A participação do seu filho (a) não implicará em despesa por parte do senhor, ou dele (a) e nem riscos para a saúde dele (a) e do senhor (a) ou de sua família, apenas implicará na disponibilidade de aproximadamente 30 minutos para dizer o que ele pensa sobre a juventude, participação, violência, paz, sobre o bairro, a família e a escola.

Prometemos que logo que terminar o trabalho vamos retornar ao senhor (a) e ao seu filho (a), os resultados da pesquisa através da realização de um seminário na região e de relatório para entidades, órgãos públicos, e setores envolvidos no estudo. Agradeço desde já a sua colaboração.

Agradeço desde já a sua colaboração. 


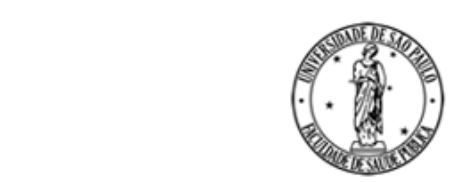

UNIVERSIDADE DE SÃO PAULO

FACULDADE DE SAÚDE PÚBLICA

COMITÊ DE ÉTICA EM PESQUISA - COEP/FSP

Av. Dr. Arnaldo 715 - 01246-904-São Paulo-SP - Tel. (55-11) 3061-7779 e-mail:coep@fsp.usp.br

IV - INFORMAÇÕES DE NOMES, ENDEREÇOS E TELEFONES DOS RESPONSÁVEIS PELO ACOMPANHAMENTO DA PESQUISA PARA CONTATO.

Nome: Fátima Madalena de Campos Lico. Telefone: 30854760 /96315137

Endereço: Av. Dr Arnaldo No: 715

Bairro: Cerqueira César Cidade: São Paulo CEP: 01246-904

Nome: Márcia Faria Westphal

Telefone: 30617766

Endereço: Av. Dr Arnaldo No. 715

Bairro: Cerqueira César

Cidade: São Paulo. CEP: 01246-904

\section{V - CONSENTIMENTO PÓS-ESCLARECIDO}

Declaro que, após convenientemente esclarecido pelo pesquisador e ter entendido o que me foi explicado, consinto que meu filho (filha) participe do presente Protocolo de Pesquisa.

São Paulo, de de 
Prefeitura do Município de São Paulo

Secretaria Municipal da Saúde CODEPPS

COMITÊ DE ÉTICA EM PESQQUISA

São Paulo, 06 de março de 2006

PARECER N ${ }^{\circ} 0042 / 2006$ - CEP-SMS

Prezado (a) Senhor (a),

Pelo presente, informo que o Comitê de Ética em Pesquisa da Secretária Municipal de Saúde de São Paulo analisou, e APROVOU, de acordo com a Resolução CNS 196/96, o protocolo de pesquisa CAAE - 00015/06 "Juventude, Violência e Ação Coletiva", de autoria do(a) pesquisador(a) FÁTIMA MADALENA DE CAMPOS LICO

Como procedimento adotado por este Comitê de Ética em Pesquisa, solicitamos a inclusão, no Termo de Consentimento Livre e Esclarecido do seguinte: qualquer questão, dúvida. esclarecimento ou reclamação sobre os aspectos éticos dessa pesquisa, favor entrar em contato com: Comitê de Ética em Pesquisas da Secretaria Municipal da Saúde de São Paulo - Rua General Jardim, $36-2^{\circ}$ andar - Telefone: 3218-4043-e-mail: smscep@.prefeitura.sp.gov.br.

Lembramos que este parecer não basta para que seu estudo possa se realizar dentro da unidade, é necessária também a permissão administrativa da autoridade sanitária.

Salientamos os seguintes aspectos a serem considerados pelo pesquisador:

- O sujeito da pesquisa tem a liberdade de recusar-se a participar ou de retirar seu consentimento em qualquer fase da pesquisa, sem penalização alguma ou sem prejuízo ao seu cuidado (Res. CNS 196/96 - item IV.1f) e deve receber uma cópia do Termo de Consentimento livre e esclarecido, na íntegra, por ele assinado (item IV.2.d)

- O pesquisador deve desenvolver a pesquisa conforme delineada no protocolo aprovado. Eventuais modificações ou emendas ao protocolo devem ser apresentadas ao CEP de forma clara e sucinta, identificando a parte do protocolo a ser modificada e suas justificativas. $O$ relatório final deve ser apresentado ao CEP, logo que o estudo estiver concluído.

Atenciosamente

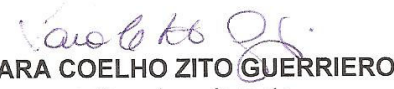

Coordenadora do

Comitê de Ética em Pesquisa da

Secretária Municipal da Saúde - CEPSMS

Ilustríssimo (a). Senhor (a).

FÁTIMA MADALENA DE CAMPOS LICO

NESTA

Rua General Jardim, $36-2^{\circ}$ andar - Vila Buarque - São Paulo, SP - CEP 01223-010 Telefone: (11) 3218-4043

Rua General Jardim, $36-2$ andar - Vila Buarque - Sao Paulo, SP - CEP Or229-10to Telesone:(11) nzzao/cepsms/ 